\title{
Rainfall partitioning in differently used montane rainforests of Central Sulawesi, Indonesía
}

\section{Dissertation}

zur Erlangung des akademischen Grades Doctor of Philosophy (PhD) der Fakultät für Forstwissenschaften und Waldökologie der Georg-August-Universität Göttingen

vorgelegt von

\section{Johannes Dietz}

\section{geboren in Würzburg}

\section{Göttingen, 2007}
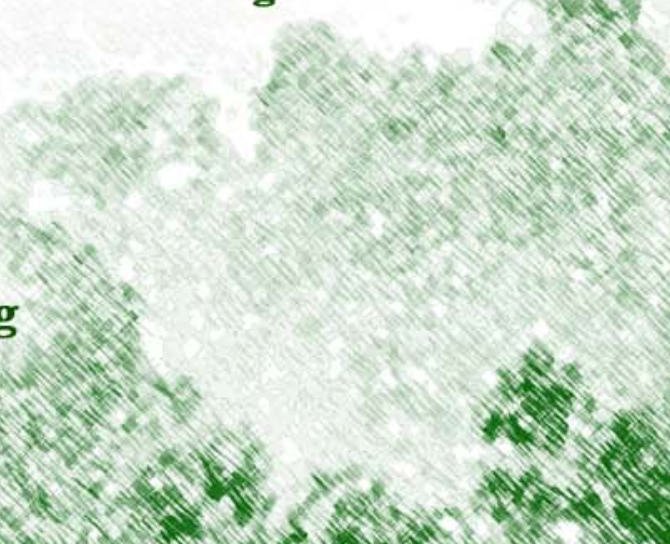
1. Gutachter: Prof Dr. Dirk Hölscher

2. Gutachter: Prof. Dr. Christoph Leuschner

Tag der mündlichen Prüfung: 31.01.2007 


\section{Rainfall partitioning in differently used montane rainforests of Central Sulawesi, Indonesia}

Johannes Dietz

\section{Summary}

High deforestation rates are reported for many tropical regions and a viable option for the conservation of undisturbed tropical forests lies in protected areas such as national parks. These sanctuaries are often surrounded by buffer zones where low impact forest management is permitted. The ecological effects of such low to moderate forest uses have been underestimated in the past because many studies had rather focused on scenarios of complete forest conversion to agricultural lands. Thus, underestimations of forest degradation have resulted in substantial uncertainties for both regional scenarios and large scale model predictions of tropical biomass resources and water fluxes. In this context, it is most obvious that canopy water fluxes will also directly respond to altered forest structure, and particularly interception as an interface between atmospheric and terrestrial water fluxes plays a decisive role.

The field studies were conducted between October 2003 and May 2005 within the interdisciplinary research project 'Stability of Rainforest Margins in Indonesia' (STORMA) along the margins of the Lore Lindu National Park in Central Sulawesi, Indonesia. The objectives of this study were (i) to quantify differences in the structure of the investigated forests, which were subject to different forest use; (ii) to determine throughfall, stemflow and interception in those differently used forests and to relate observed patterns in rainfall partitioning also to structural properties of the forest stands; and (iii) to assess the vertical distribution of leaf wetness duration in the forest canopy in relation to temporal patterns of precipitation.

Data on the influence of different forest use intensity on stand structure and rainfall partitioning with its temporal and spatial distribution were collected in the vicinity of the village Toro. There, stands of four forest types were analyzed which were under increasingly intensive management practices rooted in local traditions: (i) natural forest (NF), (ii) forest subject to small-diameter timber extraction (STE), (iii) forest subject to large-diameter timber extraction (LTE), and (iv) cacao agroforest (AF) under trees remaining from the natural forest. The study plots of 0.15 ha each, with three replicates per use type, were situated between 800 to $1140 \mathrm{~m}$ asl within the lower montane rainforest. In the region annual rainfall ranged locally from 2437 to $3424 \mathrm{~mm}$. In the natural forests, Meliaceae, Lauraceae, Sapotaceae, and Fagaceae dominated with decreasing number of species and endemics with use intensity, while Theobroma cacao dominated the agroforest. Per research plot, 30 throughfall gauges and ten stemflow collectors were installed, with five collectors for gross precipitation positioned in clearings adjacent to the study sites. Data on leaf wetness duration coupled with rainfall partitioning and stand structure were collected in a natural forest in Bariri at $1400 \mathrm{~m}$ asl, the site of a bioclimatological tower. Surface wetness was recorded along a vertical profile within the canopy with 30 automatic sensors while the setup on the 0.15 ha plot was identical to the sites in Toro. 
This study showed that:

- Many forest structural parameters reflected the gradient of forest use intensity. Tree basal area $(\mathrm{dbh} \geq 10 \mathrm{~cm})$ ranged from relatively high median values in the NF $\left(48.1 \mathrm{~m}^{2} \mathrm{ha}^{-1}\right)$ to $23.4 \mathrm{~m}^{2}$ per ha in the AF, which was paralleled by a decrease in tree height. Highest stem density was recorded where abundant tree regeneration had resumed in gaps resulting from the extraction of large timber (LTE), and it was lowest in the AF. Canopy openness was lowest in STE (7\%) and highest in cacao agroforest (16\%). Estimated leaf area index (LAI), based on the analysis of hemispherical photos, reached a median of $6.4 \mathrm{~m}^{2} \mathrm{~m}^{-2}$ for NF, 5.2 for STE, 4.9 for LTE, and 5.7 for AF.

- $\quad$ Throughfall (Tf) reached a median of $70 \%$ of gross precipitation $(\mathrm{Pg})$ over all NF plots, 79 and $80 \%$ for STE and LTE, respectively, and $81 \%$ for AF. Stemflow $(S f)$ was below $1 \%$ in all studied use types, although occasional palms (Arenga pinnata) provided exceptionally high yields. Thus, rainfall interception (I) was highest on NF plots where $30 \%$ of $P g$ (median) was re-evaporated back into the atmosphere, and much lower in the three other use types (18-20\%). Leaf area index by itself did not correlate with the pattern of rainfall partitioning in the twelve stands, while interception increased significantly with mean tree height $\left(r^{2}=0.63\right)$. However, in a multiple linear regression, the combination of tree height and LAI explained $81 \%$ of the variance in interception. A possible reason for this tree heightLAI-interception relationship is that tall trees increase the vertical extension of foliage and other canopy components contributing to the canopy water storage, resulting in a higher canopy roughness and a more effective energy exchange with the atmosphere. Under the prevailing conditions in the study region, this would allow the canopy of taller stands to dry up faster between subsequent rainfall events and provide higher water storage for interception at relatively similar leaf area.

- A long duration of leaf wetness and insufficient drying of leaves was confirmed by evidence from the leaf wetness experiment. The canopy was wet during an average of 25 to $30 \%$ of time during a three-month observation period. However, comparing extreme two-week scenarios within that period, surface wetness lasted still for $5 \%$ of the time in a relatively dry period, whereas the canopy was wet during 45 to $55 \%$ of the time in a rainy period. In the lower shade canopy, continuous surface wetness for periods of up to 22 hours and more existed frequently, although rainfall occurred only during afternoon thunderstorms of limited duration. The long duration of surface wetness has implications for forest interception models which commonly assume a complete drying of the canopy between conescutive rainfall events. Beyond its limiting effects on the available canopy water storage for interception between successive storms, the long duration of surface wetness may also discriminate eco-physiological functions such as gas exchange, leaf growth, and favor leaf colonization by epiphylls.

- Additionally, substantial contrasts in wetness conditions under intensified forest use were suggested from observations on the variability of throughfall. Rainfall on 26 days led to significant differences in $\mathrm{T} f$ between a NF and an AF (median of $38 \%$ and $68 \%$ of $P g$, respec- 
tively). Throughfall in the NF exceeded $200 \%$ of $P g$ in $0.3 \%$ of all measurements while this was observed in $4.5 \%$ of all measurements in the AF. In the NF, the coefficient of variation (cv) of $\mathrm{Tf}$ was $105 \%$ for rainfall events of $\mathrm{Pg}<2 \mathrm{~mm}$, but stabilized at a $c v$ of $\sim 40 \%$ once $\mathrm{Pg}$ exceeded $5 \mathrm{~mm}$. In the $\mathrm{AF}$, the $c v$ exceeded the NF at $P g>5 \mathrm{~mm}$ and tended to increase with increasing rainfall intensity. This contrasting response of spatial $T f$ variability in NF and $\mathrm{AF}$ to rainfall intensity suggests substantially altered pathways of $\mathrm{Tf}$ in the canopies of $\mathrm{NF}$ and $\mathrm{AF}$.

In this study, gradually lowered mean tree height of forests through human management led to lower interception and increased spatial variation of throughfall at high rainfall intensities. Leaf wetness lasted longer in the lower than in the upper canopy and its long duration reduced the available canopy water storage for interception between successive storms.

Within the context of an ongoing interdisciplinary research project, the description of such close relationships between forest structure and hydrological key parameters is valuable. Results and data of the rainfall partitioning study are now used to regionalize patterns of potential interception by combining remote sensing data with information on the impact of forest structure. Data on leaf wetness duration may complementarily support bioclimatological investigations of leaf gas exchange. 


\section{Niederschlagsaufteilung in verschieden genutzten montanen Regenwäldern Zentralsulawesis, Indonesien}

Johannes Dietz

\section{Zusammenfassung}

Die Entwaldung in vielen tropischen Regionen der Erde schreitet mit hohem Tempo voran und eine praktikable Möglichkeit natürliche tropische Regenwälder zu erhalten liegt in der Ausweisung von Nationalparks. Solche Schutzgebiete sind häufig von Pufferzonen umgeben, die ausschließlich zu geringfügiger Waldnutzung berechtigen. Die Auswirkungen dieser geringen bis mäßigen Nutzungsformen wurden bisher unterschätzt, da in vielen Untersuchungen die vollständige Konversion von Wäldern zu Agrarland im Mittelpunkt stand. Daher führte die Unterschätzung dieser Walddegradation zu erheblichen Unsicherheiten sowohl in regionalen Szenarien als auch in Aussagen überregionaler Modelle für tropische Biomassebestände und Wasserflüsse. In diesem Zusammenhang ist es offensichtlich, dass Wasserflüsse im Kronenraum direkt auf Veränderungen der Bestandesstruktur reagieren, wobei besonders der Interzeption als Schnittstelle zwischen atmosphärischen und terrestrischen Wasserflüssen eine bedeutende Rolle zukommt.

Die Felduntersuchung wurde zwischen Oktober 2003 und Mai 2005 als Teil des interdisziplinären Forschungsprojekts zur ,Stabilität von Regenwaldrandzonen in Indonesien' (STORMA) durchgeführt und konzentrierte sich auf den Randbereich des Lore Lindu Nationalparks in Zentralsulawesi, Indonesien. Gegenstand dieser Studie war es, (i) die strukturellen Unterschiede in den untersuchten Waldbeständen zu quantifizieren, die unter verschiedener Nutzung standen; (ii) den Bestandesniederschlag, Stammabfluss und Interzeption in diesen unterschiedlich genutzten Wäldern zu messen und bei den ermittelten Mustern der Niederschlagsaufteilung die Struktureigenschaften dieser Wälder zu berücksichtigen; und (iii) die Dauer von Blattnässe im vertikalen Kronenprofil zu bestimmen und diese mit zeitlichen Mustern der Niederschlagsverteilung und -dauer zu vergleichen.

Die Datenaufnahme zum Einfluss verschiedener Waldnutzungsintensitäten auf die Bestandesstruktur und die Niederschlagsaufteilung mit ihrer zeitlichen und räumlichen Verteilung fand in der Gegend um die Ortschaft Toro statt. Dort wurden vier zunehmend intensive Waldnutzungsformen analysiert, die in lokalen Traditionen verankert sind: (i) Naturwald (NF), (ii) Wald mit reiner Nutzung gering mächtiger Bäume (STE), (iii) Wald mit selektivem Einschlag starker Hölzer (LTE), und (iv) Kakao-Agroforst (AF) unter dem Schirm einzelner übriger Naturwaldbäume. Die jeweils 0,15 ha großen Untersuchungsflächen mit drei Wiederholungen pro Nutzungstyp lagen zwischen 800 und $1140 \mathrm{~m}$ ü NN innerhalb des submontanen Regenwaldes. Der Jahresniederschlag variierte in der Region kleinräumig zwischen 2437 und 3424 mm. In den Naturwäldern dominierten Meliaceae, Lauraceae, Sapotaceae, and Fagaceae, wobei die Artzahlen und Endemiten mit der Nutzungsintensität abnahmen und Theobroma cacao im Agroforst dominierte. Auf jeder Untersuchungsfläche wurden 30 Bestandesniederschlags- und zehn Stammabflusssammler installiert, sowie fünf Sammler für Freilandniederschlag in Lichtungen in unmittelbarer Nähe zur Untersuchungsfläche. Messungen zur Blattnässedauer, sowie zu Niederschlagsaufteilung und 
Bestandesstruktur, wurden auf einer Naturwaldfläche bei Bariri auf $1400 \mathrm{~m}$ ü NN durchgeführt. Oberflächenfeuchte wurde mit 30 Sensoren an einem bestehenden mikrometeorologischen Messturm entlang eines Vertikalprofils gemessen, während die Instrumentierung des 0.15 ha Plots den Flächen in Toro glich.

Maßgebliche Ergebnisse der Untersuchung sind:

- Viele Bestandesstrukturparameter folgten dem Gradienten der Waldnutzungsintensität. Die Grundfläche (bhd $\geq 10 \mathrm{~cm}$ ) fiel von relativ hohen Medianwerten $\left(48,1 \mathrm{~m}^{2} \mathrm{ha}^{-1}\right)$ der NFFlächen auf 23,4 $\mathrm{m}^{2} \mathrm{ha}^{-1}$ im AF, was auch mit einem Rückgang der Baumhöhen einherging. Die Stammzahl erreichte ihr Maximum, wo die Baumregeneration in Lücken nach Einschlag großer Bäume bereits eingesetzt hatte (LTE), und war im AF am niedrigsten. Der niedrigste Kronenöffnungsgrad fand sich im STE (7\%), während er im AF (16\%) die höchsten Werte erreichte. Der Blattflächenindex (LAI), ermittelt durch die Analyse hemisphärischer Fotos, einen Median von 6,4 $\mathrm{m}^{2} \mathrm{~m}^{-2}$ im NF; 5,2 im STE; 4,9 im LTE; und 5,7 im AF.

- Der Median des Bestandesniederschlags (Tf) aller NF-Flächen lag bei $70 \%$ des Freilandniederschlags $(\mathrm{Pg})$, und bei 79 bzw. 80\% im STE und LTE, sowie bei 81\% im AF. Der Stammabfluss (Sf) überstieg in keinem der untersuchten Nutzungstypen 1\%, obwohl gelegentlich vorkommende Palmen (Arenga pinnata) ergiebige Mengen lieferten. Daraus ergaben sich die höchste Niederschlagsinterzeption (I) für NF, wo 30\% des $\mathrm{Pg}$ (Median) direkt zurück die Atmosphäre evaportierten, und weitaus niedrigere Werte für die anderen drei Nutzungstypen (18-20\%). Der Blattflächenindex für sich als Einzelfaktor korrelierte nicht mit dem Muster der Niederschlagsaufteilung aus den zwölf Beständen, während die Interzeption signifikant mit der mittleren Baumhöhe anstieg $\left(r^{2}=0.63\right)$. Jedoch erklärte die Kombination von Baumhöhe und LAI über eine multiple lineare Regression 81\% der Varianz der Interzeption. Als Grund für diesen Zusammenhang zwischen Baumhöhe, LAI und Interzeption ist denkbar, dass hohe Bestände die vertikale Ausdehnung der Blattfläche und anderer wasserspeichernder Kronenelemente erhöhen. Dies führt dann zu einer größeren Oberflächenrauhigkeit und einem effizienteren Energieaustausch mit der Atmosphäre. Unter den vorherrschenden Bedingungen der untersuchten Region könnte dadurch der Kronenraum höherer Bestände zwischen aufeinander folgenden Niederschlagsereignissen schneller abtrocknen, und somit bei relativ vergleichbarer Blattfläche mehr Wasserspeicher für die Interzeption bereitstellen.

- $\quad$ Lange Blattnässedauer und unvollständige Abtrocknung der Blätter stellte zudem das Blattnässeexperiment unter Beweis. In einem Beobachtungszeitraum von drei Monaten war der Kronenraum im Schnitt 25-30\% der Zeit nass. Der Vergleich zweier extremer Szenarien von jeweils zwei Wochen innerhalb dieser Periode zeigte allerdings, dass Blattnässe auch in relativen Trockenperioden zu 5\% der Zeit existierte, während in einer regenreichen Periode die Nässe in der Krone 45-55\% der Zeit anhielt. In unteren, beschatteten Kronenbereichen währte die Blattnässe häufig bis über 22 Stunden, obwohl Niederschläge lediglich nachmittags in Form zeitlich begrenzter Gewitterschauer fielen. Die lange Dauer von Blattnässe hat Auswirkungen auf die Waldinterzeptionsmodellierung, die in den meisten Fällen annimmt, 
der Kronenraum trockne zwischen aufeinander folgenden Niederschlagsereignissen vollständig ab. Neben ihrer limitierenden Wirkung auf den verfügbaren Wasserspeicher für die Interzeption, kann langanhaltende Blattnässe zudem ökophysiologische Funktionen wie Gaswechsel und Blattwachstum herabsetzen und die Besetzung der Blätter durch Epiphylle fördern.

- Zusätzlich legte die Untersuchung der räumlichen Variabilität des Bestandesniederschlags nahe, dass intensive Waldnutzung zu ausgeprägten Unterschieden der Feuchtigkeitsbedingungen führt. Messungen an 26 Regentagen zeigten auffallende Unterschiede im Median des Tf zwischen einem NF (38\% von $P g$ ) und einem AF (68\% von $P g$ ). Der Tf überstieg $200 \%$ des $\mathrm{Pg}$ im NF in 0,3\% aller Messungen, wohingegen dies im AF in 4,5\% aller Messungen verzeichnet wurde. Im NF betrug der Variationskoeffizient (cv) 105\% bei Regenfällen von $\mathrm{Pg}<2 \mathrm{~mm}$, stabilisierte sich aber bei einem $c v$ von $\sim 40 \%$ sobald $\operatorname{Pg} 5 \mathrm{~mm}$ überstieg. Dagegen übertraf der $c v$ im $\mathrm{AF}$ den des NF bei $P g>5 \mathrm{~mm}$ und neigte dazu, mit zunehmeder Regenintensität weiter zu steigen. Diese gegenläufige Reaktion der räumlichen $T f$-Variabilität zwischen NF und AF weist auf wesentlich geänderte Kanalisierungen des Tf im Kronenraum von NF und AF hin.

Menschliche Nutzung reduzierte allmählich die mittlere Höhe der Bestände und führte in dieser Studie zu verminderter Interzeption und erhöhte die räumliche Variabilität des Bestandesniederschlag bei hohen Niederschlagsintensitäten. Blattnässe hielt sich länger in den unteren gegenüber den oberen Kronenbereichen und die lange Dauer der Blattnässe verminderte den verfügbaren Wasserspeicher für die Interzeption zwischen aufeinanderfolgenden Regenereignissen

Im Hinblick auf ein laufendes interdisziplinäres Forschungsprojekt ist vor allem die Erkenntnis solch enger Zusammenhänge zwischen Bestandesstruktur und hydrologischen Schlüsselgrößen von maßgeblicher Bedeutung. Die Ergebnisse und Daten der Untersuchungen zu Niederschlagsaufteilung werden nun dazu verwendet, Muster der potenziellen Interzeption zu regionalisieren, indem man Fernerkundungsdaten mit der Information über die Effekte von Bestandesstrukturen verknüpft. Die Daten über Blattnässedauer können zudem bioklimatologische Untersuchungen des Blattgaswechsels ergänzend unterstützen. 
This dissertation is substantiated by the following four publications:

1 Forest structure as influenced by different types of community forestry in a lower montane rainforest of Central Sulawesi, Indonesia.

Dietz J · Hölscher D · Leuschner Ch · Malik A · Amir MA (2007)

In: Tscharntke T, Leuschner Ch, Zeller M, Guhardja E, Bidin A (eds) The stability of tropical rainforest margins, linking ecological, economic and social constraints of land use and conservation. Springer Verlag Berlin, 133-148.

$2 \quad$ Rainfall partitioning in relation to stand structure in differently managed montane forest stands in Central Sulawesi, Indonesia.

Dietz J · Hölscher D · Leuschner Ch · Hendrayanto (2006)

In: Forest Ecology and Management 237: 170-178. doi:10.1016/ j.foreco.2006.09.044

3 Vertical patterns and duration of surface wetness in an old-growth tropical montane forest, Indonesia.

Dietz J · Leuschner Ch · Hölscher D · Kreilein H (in press)

In: Flora (FLORA50103) doi:10.1016/j.flora.2006.03.004

$4 \quad$ Spatial and temporal variability of throughfall in a tropical old-growth forest and an agroforestry system in Sulawesi (Indonesia).

Klank Ch · Dietz J · Hölscher D · Leuschner Ch (under review) In: Agroforestry Systems (AGFO176) 


\section{Table of Contents}

\section{Summary}

\section{Zusammenfassung}

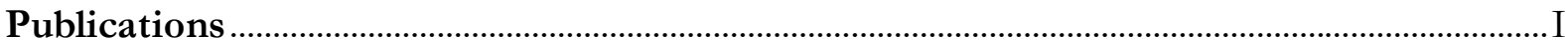

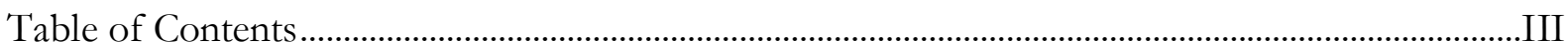

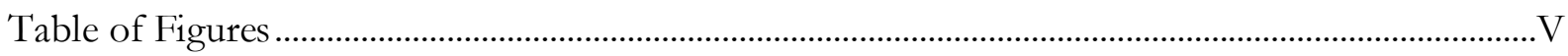

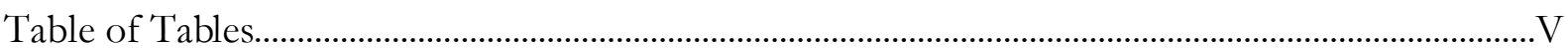

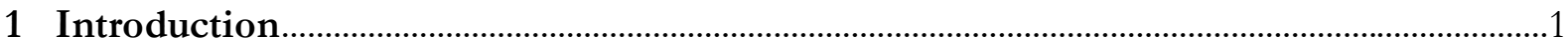

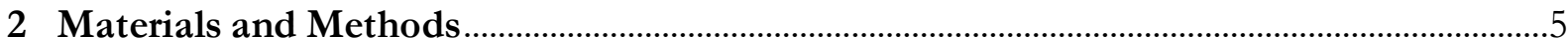

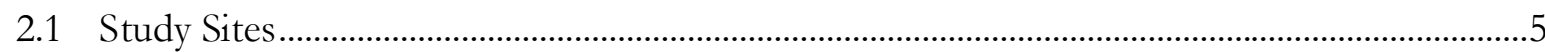

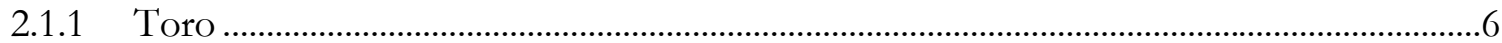

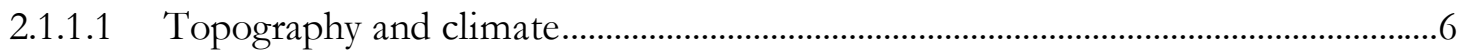

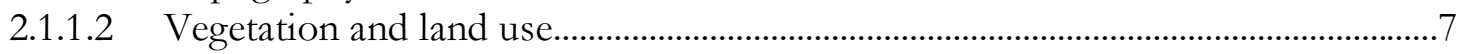

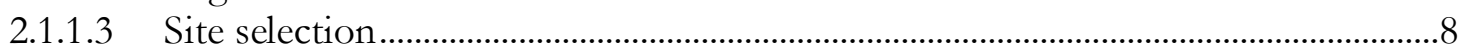

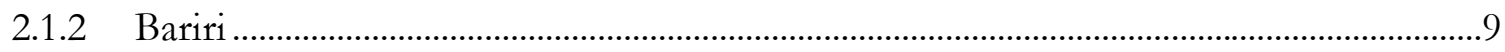

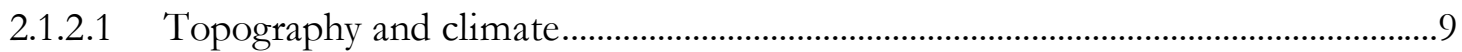

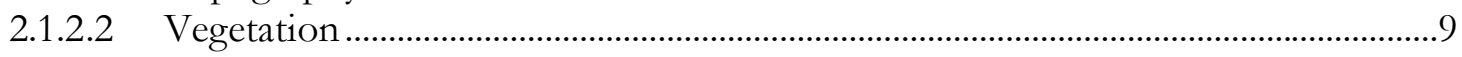

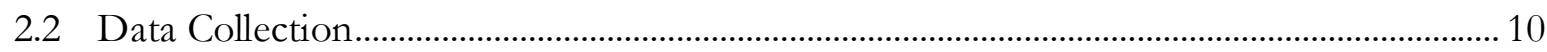

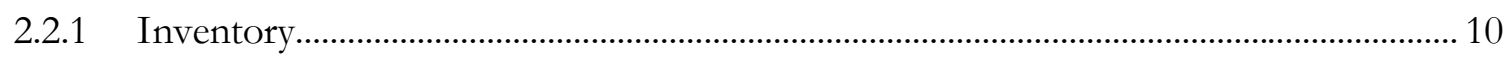

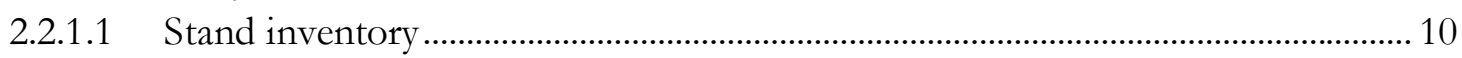

2.2.1.2 Hemispherical photography ................................................................................ 10

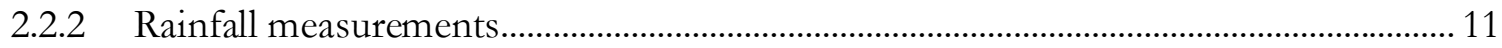

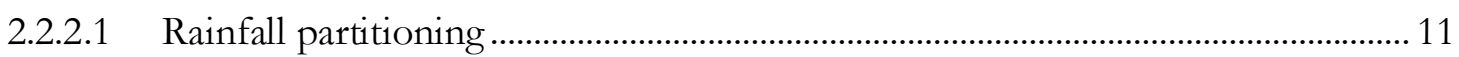

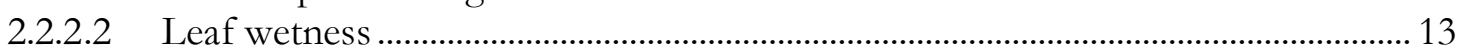

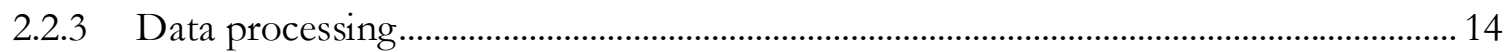

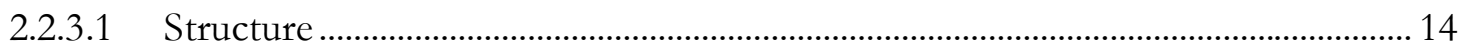

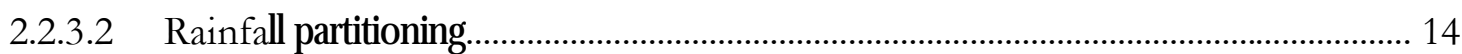

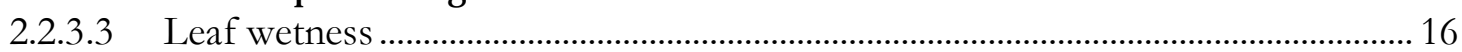




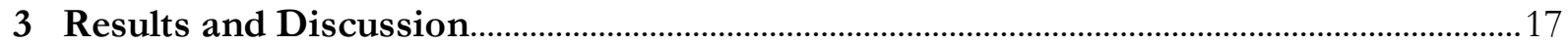

3.1 Different Forest Use and Forest Structure............................................................................... 17

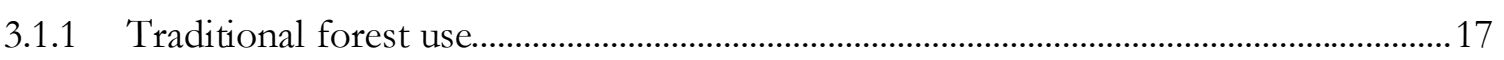

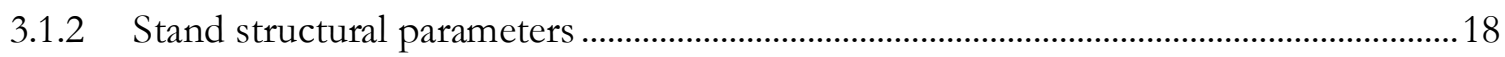

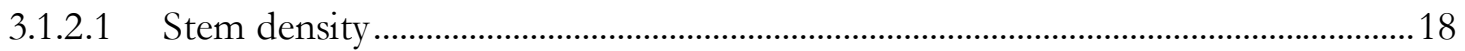

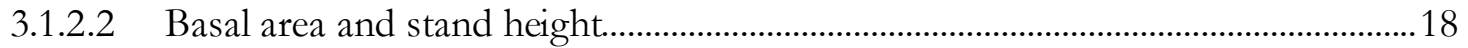

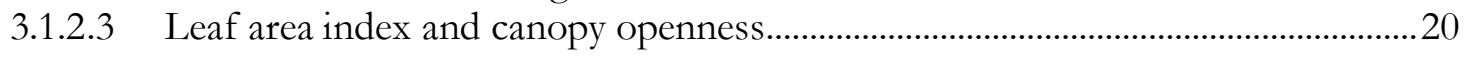

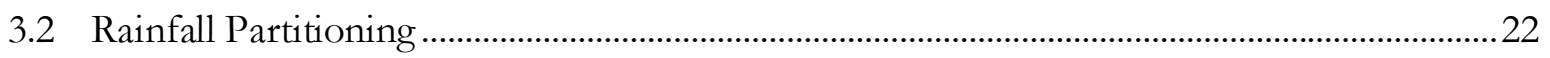

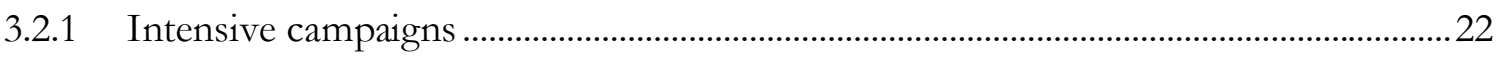

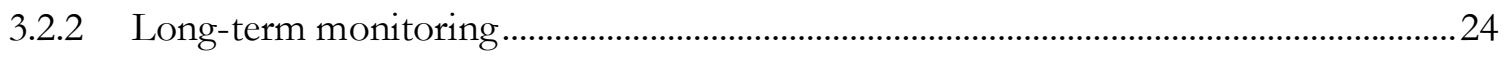

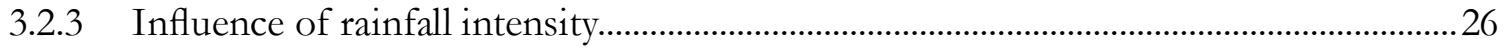

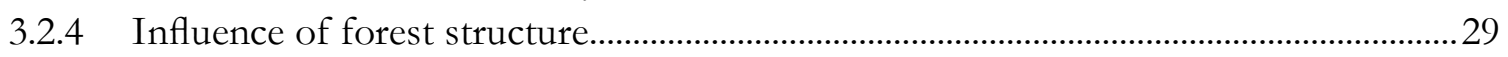

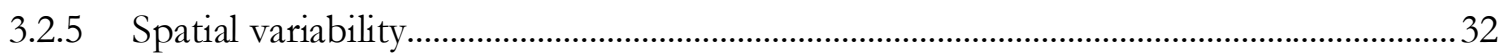

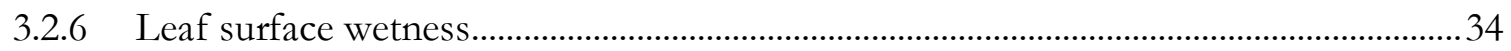

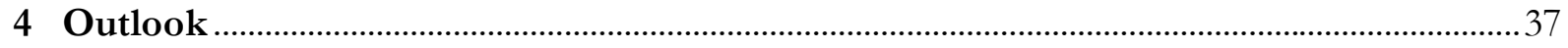

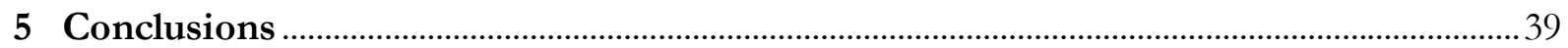

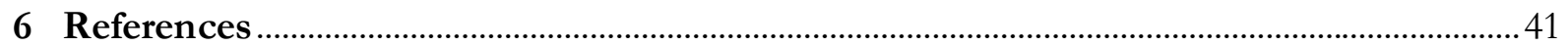

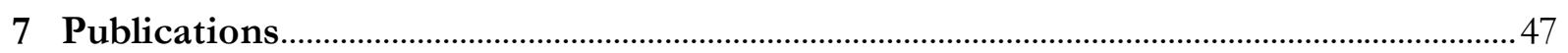

7.1 Dietz J, Hölscher D, Leuschner Ch, Malik A, Amir MA (2007)............................................... 49

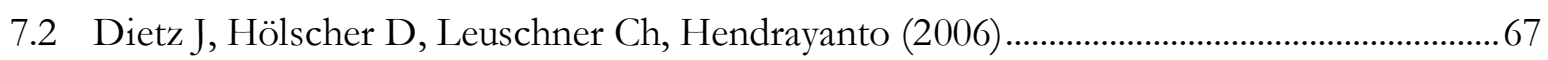

7.3 Dietz J, Leuschner Ch, Hölscher D, Kreilein H (in press)......................................................... 79

7.4 Klank Ch, Dietz J, Hölscher D, Leuschner Ch (under review).................................................89

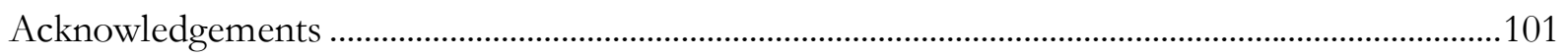

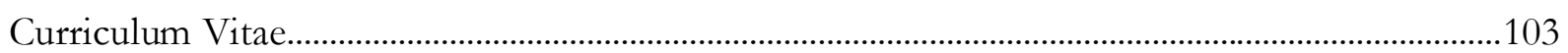




\section{Table of Figures}

Fig. 1. Sulawesi in the Indonesian archipelago east of the Wallace line................................................5

Fig. 2. Location of the study plots in the surrounding of the village of Toro.....................................6

Fig. 3. Climate diagram from data recorded at the automatic weather station in Toro....................6

Fig. 4. Climate diagram from data recorded at the automatic weather station in Bariri ....................9

Fig. 5. Hemispherical photograph from a natural forest site in Toro................................................ 10

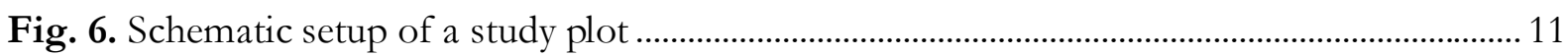

Fig. 7. Schematic sketch of a precipitation collector ...................................................................... 11

Fig. 8. Schematic sketch of a stemflow collection unit.................................................................... 12

Fig. 9. Schematic sketch of the experimental setup for the leaf wetness measurements................ 13

Fig. 10. Stem densities in four different forest use types .................................................................. 18

Fig. 11. Basal area of natural forests in the region of Toro, Central Sulawesi................................... 18

Fig. 12. Leaf area index (LAI) estimates from a natural forest on three different dates ................. 20

Fig. 13. Range and variability of throughfall measurements during the intensive campaign......... 23

Fig. 14. Histograms of the throughfall distribution on the four investigated long term plots ...... 25

Fig. 15. The variability of throughfall measurements on the four investigated long term plots ... 27

Fig. 16. Relationship between weekly gross precipitation and its coefficient of variation.............. 28

Fig. 17. The relationship of basal area of all trees and mean tree height to interception................. 29

Fig. 18. Rainfall interception as a function of mean tree height .......................................................... 31

Fig. 19. The variability of throughfall measurements using the roving gauge technique................ 32

Fig. 20. Relationship between gross precipitation and the coefficient of variation .......................... 32

Fig. 21. Duration of surface wetness inside the forest........................................................................ 35

Fig. 22. Duration of surface wetness as percentage of a two-week observation period.................. 36

Fig. 23. Leaf area index as estimated from hemispherical photos along a vertical profile.............. 36

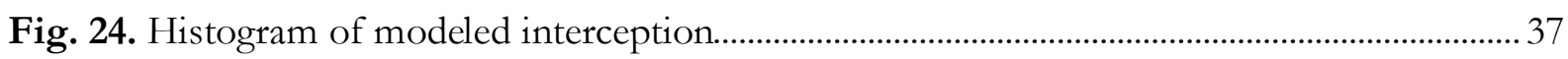

Fig. 25. Modelled interception of forest in the Toro valley.................................................................... 37

\section{Table of Tables}

Table 1. Rainfall characteristics during the study period.

Table 2. Geographical position and site characteristics of the study plots ...........................................8

Table 3. Aboveground forest structure in the study stands............................................................. 19

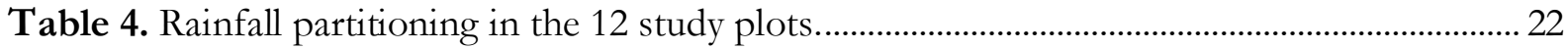

Table 5. Rainfall partitioning in the 4 selected plots from the long-term monitoring.................... 24

Table 6. Rainfall partitioning on the long-term monitoring 4 plots by weekly sums of $P g . . . . . . . . . .26$

Table 7. Spearman's correlation coefficients between rainfall partitioning and stand structure... 30

Table 8. Mantel's correlation coefficients on selected variables ............................................................. 33

Table 9. Correlation coefficients from the partial Mantel test on selected variables........................ 34 


\section{Introduction}

Over the past decades, tropical rainforests have suffered substantial losses through conversion to other land cover types. South East Asia and especially some regions on the Indonesian archipelago including Central Sulawesi were identified as areas of particularly high deforestation rates (Achard et al. 1998, FAO 2001, Drigo 2004). However, there is increasing awareness that, in addition to conversion, more subtle forms of forest disturbance as through encroachment by selective logging are difficult to identify via satellite leading to an underestimation of their extent (Asner et al. 2005). For five states of the Brazilian Amazon, the analysis of selective logging doubled previous estimates of the total annual extent of forest degraded by human activities (Asner et al. 2005).

These high rates of forest conversion, together with the rapidly proceeding forest degradation, have long since called upon improved conservation strategies (e.g. Bruenig 1996, Bawa and Seidler 1998, Soulé and Sanjayan 1998). It has been emphasized that protection requires the interaction with the people that traditionally live in and around the forests (Schweithelm 2004). Contemporary policies advocate buffer zone management by a low impact forest management which, according to Schweithelm (2004), can be developed from the experience of traditional communities who regulate the access to land and forest resources. For the Lore Lindu National Park in Central Sulawesi, such traditional structures and regulations are found in the village of Ngata Toro (Helmi 2005). There, customary law has created a zonation of different use types of forest which are distinguished by the local population. As such definitions of land use are highly subjective, there is a need to quantify such categories by objective means (Drigo 2004). Drigo (2004) suggests the transformation from land use practice to land cover types where structural characteristics can be measured and monitored. Thus, characterizing traditional forest use practices as exercised in the region of Toro with structural properties is a prerequisite for a sound approach to the evaluation of ecological effects caused by a gradient of forest use intensity.

So far, mostly the effects of complete forest conversion to e.g. pasture land have been intensively studied; these investigations revealed severe changes in the hydrological cycle (Hodnett et al. 1995, Grip et al. 2004). Changes in the amount of water intercepted by and reevaporated from vegetation surfaces was one of the most essential alterations in hydrological fluxes resulting from forest conversion. Much less information, however, is available for more gradual changes in vegetation structure as created by different logging practices. The studies on the effect of logging on rainfall partitioning so far yielded contrasting results. In a lowland dipterocarp forest on Borneo, Central Kalimantan, the rainfall interception was $11 \%$ of gross precipitation $(\mathrm{Pg})$ in an unlogged natural forest and $6 \%$ of $\mathrm{Pg}$ in a logged forest (Asdak et al. 1998) which thus points to a decrease in interception with disturbance. However, in another lowland dipterocarp forest in northern Borneo, Sabah, it was found that $91 \%$ of $P g$ reached the ground as throughfall (Tf) in an unlogged natural forest, whereas 80 and $84 \%$ of $T f$ were recorded in forest plots subject to moderate and high human intervention (Chappell et al. 2001). Assuming stemflow to be $1 \%$ of above-canopy rainfall (Chappell et al. 2001), interception in these stands 
can be estimated with $8 \%$ of $P g$ in the undisturbed forest and with $15 \%$ and $19 \%$ of $P g$ in the two logged forests, indicating interception rates to increase with disturbance intensity (Chappell et al. 2001). Both studies from a lowland dipterocarp forests pointing to contrasting effects of logging on rainfall partitioning clearly express the need for further investigation.

Canopy water fluxes such as interception and throughfall are primarily dependent on climate factors and vegetation structure (Crockford and Richardson 2000). Canopy cover, leaf area and, more controversially discussed, bark structure are thought to be key factors for the canopy water storage capacity and thus may affect rainfall interception (Herwitz 1985, Gash et al. 1995, van Dijk and Bruijnzeel 2001a). Another factor is tree height and associated canopy roughness length that may influence the exchange of water and energy with the atmosphere (e.g. Asdak et al. 1998, Chappell et al. 2001, Hölscher et al. 2004). Stem density and crown structure may be important for stemflow generation (Hölscher et al. 2005). However, it is still difficult to assess the relative importance of these stand attributes for water turnover in the canopy. If a single stand characteristic is analyzed separately, some studies yielded unexpected results. For example, analyzing the contribution of epiphyte vegetation to interception in montane neotropical stands, two independent studies suggested that epiphytes may have little influence (Hölscher et al. 2004, Fleischbein et al. 2005). Relationships between stand structure and rainfall partitioning may sometimes be obscured by an insufficient number of study plots. In previous studies, much attention has been paid to appropriate sampling schemes within a single stand (e.g. Lloyd et al. 1988, Holwerda et al. 2006). However, gradients of changing forest structure or even more than one plot per forest type have rarely been studied so far.

In the study region, the most pronounced contrast in forest use intensity and structure existed between natural forest, where only occasional rattan collection occurs, and cacao agroforests under shade trees which remain from natural forest. This form of cacao cultivation is a common practice throughout the tropics (Imbach et al. 1989, Ruf and Schroth 2004). Since tree height and density of large stems is altered considerably with this conversion of natural forest to agroforest (Dietz et al. 2007), considerable changes in the hydrological processes such as interception, throughfall and evapotranspiration are likely to occur (Keim et al. 2005). The hydrological changes that result from the conversion of old-growth tropical forest to agroforestry systems have not been studied in detail so far, despite growing awareness of their relevance for water resource management. Existing studies reach controversial results. Sampling only under selected trees yielded only insignificant differences in throughfall between commercially used tree species and most natural forest tree species in Brazil (Schroth et al. 1999). Keim et al. (2005), however, showed that spatial variability of throughfall in a stand can be reproduced at various points in time but they still consider it difficult to predict throughfall patterns by tree locations. This was supported by a study by Imbach et al. (1989) from a rainfall partitioning investigation on stand levels, who showed that already different shade tree species had an influence on interception in cacao agroforests in Costa Rica. Moench (1991) reported marked differences in throughfall also under different agroforest systems (cardamom, pepper) and inferred implications for the reduction of soil erosion in India. Such consequences for soil moisture status, soil erosion, and 
water yield are particularly important for paddy rice cultivation and urban water demand in the wider forest margin zone.

While changed patterns in throughfall may directly affect terrestrial water balances, changed patterns in interception are more likely to affect water and gas exchange between vegetation and the atmosphere which thus influences eco-physiological characteristics of the forest. Tropical montane forests exist in relatively cool and humid climates where high rainfall amounts prevail. On the slopes of tropical mountains, convective uplift of heated air masses forces water vapor to condensate at elevations of about 1500 to $3500 \mathrm{~m}$ (Hastenrath 1991). Montane forests receive three different types of precipitation, i.e. vertical rainfall, fog interception (horizontal precipitation) and dewfall. In the context of climate change research, vertical rainfall has been studied intensively (e.g. Sperber and Palmer 1996, Kummerow et al. 2000, Baker et al. 2001). Much less is known about the other two types of precipitation. Water loss through evapotranspiration is deemed comparably small in montane forests with temperatures considerably lower than in the hot lowlands and with cloud cover frequently reducing the radiation load. Tropical montane forests are ecologically characterized by environmental constraints that could limit photosynthetic activity and turnover rates (Bruijnzeel and Veneklaas 1998). Grubb (1977) has forwarded the hypothesis that the prevalence of high air humidity would reduce tree transpiration, thereby impairing nutrient uptake and causing nutrient deficiency. Indeed, climate chamber experiments have shown that very high air humidity can reduce foliar nutrient levels of herbaceous plants (Leuschner 2002). Letts and Mulligan (2005) present further field-based evidence for the inhibition of photosynthesis and productivity by leaf wetness in neotropical montane cloud forests. High air humidity is also reported to favor pathogen attack of leaves which may reduce plant productivity (Magarey et al. 2005).

Besides linking atmospheric and plant processes, the vegetation and particularly the forest canopy plays an important role as interface between atmospheric and terrestrial water fluxes by intercepting and storing precipitated water on its foliage, branches and epiphytic components (e.g. Herwitz 1985, Bruijnzeel and Proctor 1997, Hölscher et al. 1998, 2004). So far, many interception models have resorted to the simplified assumption that the canopy would dry up completely between subsequent rainfall events (Gash 1979, van Dijk and Bruijnzeel 2001a). Simultaneously, the authors acknowledged that such postulation helps with the simplification of the model while it may not comply with realistic processes and thus restrict the effective application of the model to certain climatic conditions (see also Lloyd and Marques 1988, Dykes 1997, Llorens et al. 1997). In spite of some studies on leaf wetness in temperate zones (Brewer and Smith 1997, Klemm et al. 2002) only very few studies systematically monitored surface wetness in tropical montane forests for extended periods (Leuschner and Schulte 1991, Letts and Mulligan 2005). However, further knowledge on the duration of leaf wetness and its vertical patterns, particularly in the tropics, would generally contribute to a better understanding of interception processes by accounting for the reduction in canopy water storage by persistent leaf wetness. 
In this study, the assumption was revisited that rainfall partitioning into stemflow, throughfall and interception may change with forest use intensity and can be linked to stand structural characteristics and that leaf wetness in tropical montane rainforests is heterogeneously distributed in time and space. Therefore, the aims of the study were to:

(i) Conduct a quantitative, comparative analysis of stand structural characteristics presumed to be important for rainfall partitioning such as leaf area index, stem density, basal area and tree height under the notion of different forest use.

(ii) Determine rainfall partitioning into throughfall, stemflow and interception in the differently used forest stands.

(iii) Single out stand structural characteristics that may control the partitioning by regression analyses.

(iv) Quantify the spatial variability of throughfall with fine resolution in contrasting vegetation types.

(v) Analyze leaf wetness patterns in rainless and rainy periods and to relate wetness patterns to microclimate and rainfall regime.

Within the interdisciplinary project on the 'Stability of Rainforest Margins in Indonesia' (STORMA), this study has among others interacted with studies concerning root distribution (Leuschner et al. 2006, Hertel et al. 2007), bioclimatological research (Dietz et al., in press), and approaches to regionalization of interception (Nieschulze et al., in prep.). 


\section{Materials and Methods}

\subsection{Study Sites}

Sulawesi is with $\sim 175000 \mathrm{~km}^{2}$ the largest island of the Wallacea, a biogeographical region east of the Wallace line which separates especially the fauna of Sulawesi from the Asian continent to the west (Wallace 1869). While dominating the Wallacea region, Sulawesi is the third largest island in the Indonesian archipelago (Fig. 1). With the establishment of the Lore Lindu National Park in 1993, an area of $2290 \mathrm{~km}^{2}$ of Central Sulawesi, just south of its district capital Palu, is designated to the protection of the high biodiversity and endemism found in this region where Asian and Austronesian species merge. Stretching from about $1000 \mathrm{~m}$ to the peaks of Mt. Nokilalaki at $2355 \mathrm{~m}$ asl, this park harbors a variety of natural vegetation types.

The margin zone of this national park is constantly encroached by illegal clearing for rice and cacao cultivation or rattan collection and hunting. The aim of the interdisciplinary research project STORMA is to assess the human impacts on the park along its fringes and ultimately develop sustainable strategies for the stabilization of the rainforest margins in this region. For the present study, the study sites were chosen in the village of Toro, Kabupaten Donggala, and in the vicinity of Bariri, Kabupaten Poso.

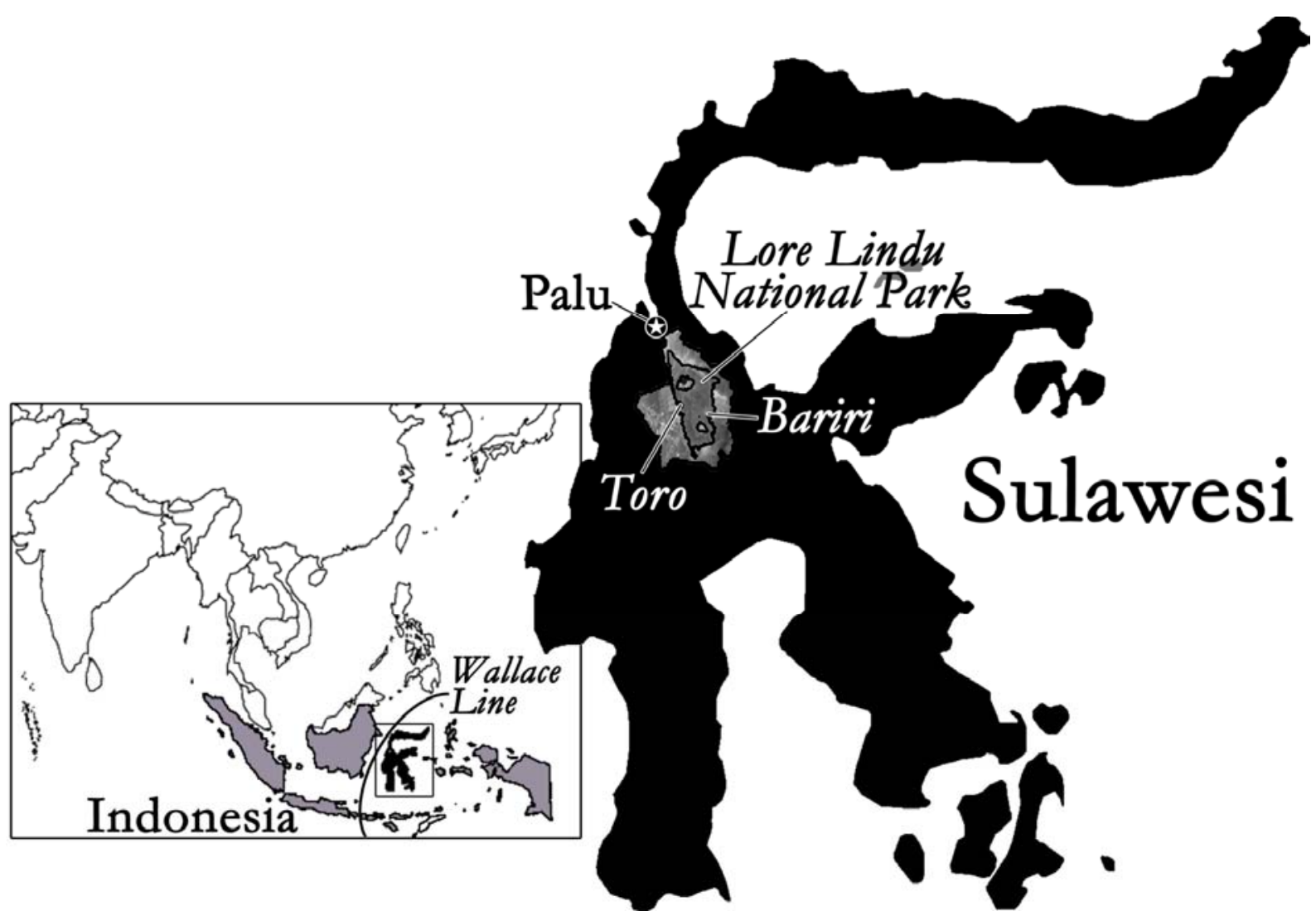

Fig. 1. Sulawesi in the Indonesian archipelago east of the Wallace line. The locations of the study sites of Toro and Bariri on the fringes of the Lore Lindu National Park are indicated south of Palu in Central Sulawesi, Indonesia. 


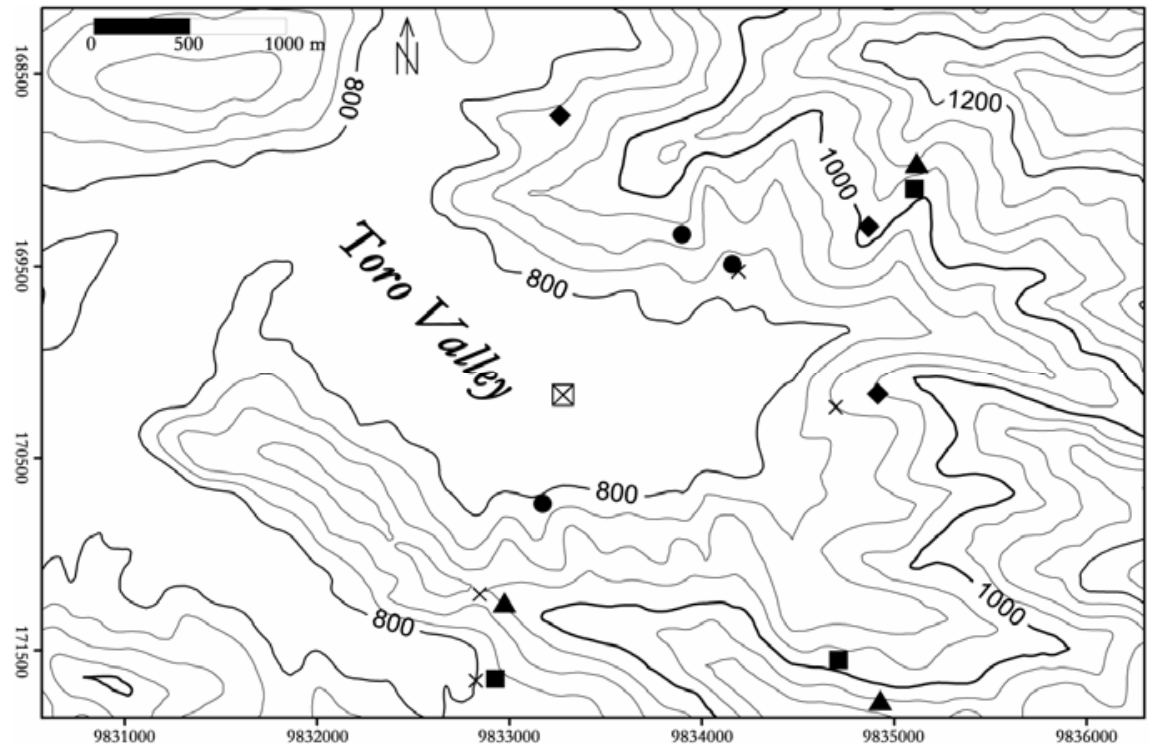

Fig. 2. Location of the study plots in the surrounding of the village of Toro, Central Sulawesi (UTM $51 \mathrm{~S}$ ). Indicated are natural forest plots $(\boldsymbol{\Delta})$, plots of small timber extraction (ם), plots of large timber extraction $(\bullet)$, and agroforest plots $(\bullet)$, the permanent rain stations $(X)$, and the automatic weather station $(囚)$.

\subsubsection{Toro}

The village of Toro is situated $\sim 110 \mathrm{~km}$ south of Palu on the western edge of the Lore Lindu National Park (Fig. 2). It is subdivided into seven subdistricts, called dusun, and comprises $\sim 2000$ inhabitants.

\subsubsection{Topography and climate}

The twin valley of Toro protrudes into the Lore Lindu National Park from west to east at an elevation of $\sim 800 \mathrm{~m}$ asl (Fig. 2). According to local perception, the $1000 \mathrm{~m}$ contour line is commonly assumed to be the delimitation to the national park. The settlements within the flat valley bottom are beaded alongside the main access roads and primary streams. According to the classification by the soil reference base (FAO 2006), dominating soil types along the edges of the plain where no rice cultivation occurs are fluvisols, anthrosols and cambisols (Häring et al. 2005). The surrounding hills rise abruptly to elevations of $>1600 \mathrm{~m}$ asl and soils are predominantly cambisols. However, depending on substrate, and slope inclination and stability, also regosols, lixisols or ferralsols occur (Häring et al. 2005).

The climate in Toro is moderately warm with an annual mean of $23.3^{\circ} \mathrm{C}$ which does not show a distinct seasonality.

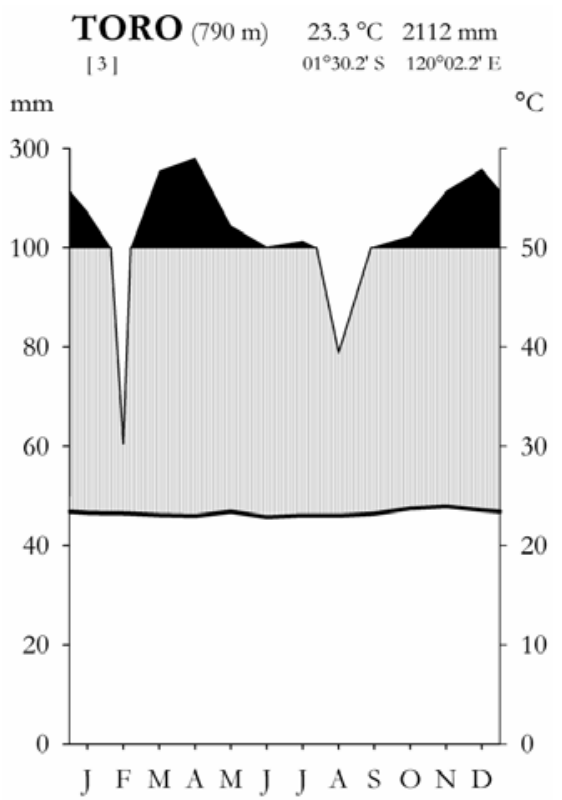

Fig. 3. Climate diagram after Walter et al. (1975) from data recorded at the automatic weather station in Toro (Kreilein et al., unpublished data). Dry periods occur occasionally but are not particularly pronounced. Driest months are February 
Table 1. Rainfall characteristics during the study period (5 April, 2004 to 4 April, 2005) at the valley bottom close to the village of Toro (790 $\mathrm{m}$ asl, Kreilein et al., unpublished data).

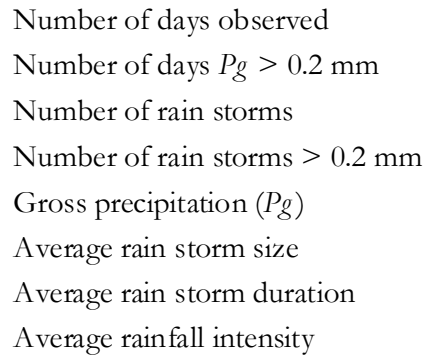

$\begin{array}{lc} & 366 \\ & 218 \\ & 526 \\ & 282 \\ \mathrm{~mm} & 1828 \\ \mathrm{~mm} & 6.5 \\ \mathrm{~h} & 1.9 \\ \mathrm{~mm} \mathrm{~h}^{-1} & 3.4\end{array}$

$\overline{\text { Individual rainstorms were defined as precipitation events of more than the minimum resolution of the tipping bucket rain gauge }}$ (i.e. $>0.2 \mathrm{~mm}$ ) and delimited from the following rainstorm by a dry period of at least 2 hours.

and August, however, the climate remains humid to perhumid throughout the year (Fig. 3). Due to the high relief energy in the surroundings orographic precipitation is likely to occur. However, the arrangement of cordilleras and ridges (Fig. 2) effectively funnels or blocks cloud movements depending on wind direction, thus rainfall amounts have been observed to vary considerably on a small spatial scale. Within the study period the annual precipitation ranged from 2437 to $3424 \mathrm{~mm}$ within less than $2.5 \mathrm{~km}$. Dew formation was observed, but extensive formation of fog was restricted to the peak regions of the surrounding slopes, far above the studied regions. Data from the automatic weather station on the valley bottom allowed a characterization of temporal rainfall patterns (Table 1), but were with an annual sum of $1828 \mathrm{~mm}$ and a rainfall intensity of $3.4 \mathrm{~mm} \mathrm{~h}^{-1}$ relatively low compared to the study sites on the hill slopes.

\subsubsection{Vegetation and land use}

The potential natural vegetation of the study site in Toro would be sub-montane tropical rainforest. However, following human settlements the valley bottom was almost completely cleared for paddy rice cultivation. Unlike the practices in the adjacent valleys, no management of particular homegardens was observed in Toro (Brodbeck 2004). Rather, the forest fringes on the lower slopes were extensively used for cacao (Theobroma cacao) agroforestry, where other crop species (e.g. Coffea spp., Durio zibethinus, Nephelium lappaceum) were grown for domestic use. Recently, the cultivation of vanilla (Vanilla spp.) has become increasingly popular. Those cacao plantations are initiated by interplanting cacao saplings with maize (Zea mays) under the thinned canopy of few remaining natural forest trees which serve for shading. In further development stages, the entire natural tree cover is continuously replaced with fast growing Fabaceae (e.g. Erythrina spp., Gliricidia spp.). These agroforests displayed the lowest plant diversity with 32 species (dbh $\geq 10 \mathrm{~cm}$ per $0.25 \mathrm{ha}$ ) and the lowest amount of endemic species (Gradstein et al. 2007).

The slopes more than 50-100 $\mathrm{m}$ above the valley bottom are commonly devoid of managed agroforest. Traditionally, this region is divided into zones of decreasing intervention. Pahawa pongko is abandoned agricultural land, followed by pangale which is the zone of preferred selective timber extraction for construction. The pangale is succeeded above by the wana zone, where only 
Table 2. Geographical position and site characteristics of the study plots in Toro and the natural forest site in Bariri.

\begin{tabular}{|c|c|c|c|c|c|c|}
\hline Forest use type & Abbr. & UTM X 51S (m) & UTM Y 51S (m) & Elevation (m asl) & Exposition & Inclination $\left({ }^{\circ}\right)$ \\
\hline Natural forest 1 & NF 1 & 171250 & 9832974 & 948 & SSE & 32.2 \\
\hline Natural forest 4 & NF 4 & 171759 & 9834927 & 1042 & WNW & 20.9 \\
\hline Natural forest 5 & NF 5 & 168961 & 9835116 & 1130 & $\mathrm{NE}$ & 17.0 \\
\hline Small timber extraction 2 & STE 2 & 171648 & 9832926 & 873 & SSE & 37.6 \\
\hline Small timber extraction 3 & STE 3 & 169097 & 9835104 & 1078 & NNE & 31.2 \\
\hline Small timber extraction 4 & STE 4 & 171550 & 9834710 & 982 & $\mathrm{~W}$ & 33.2 \\
\hline Large timber extraction 1 & LTE 1 & 169292 & 9834866 & 974 & SSW & 25.0 \\
\hline Large timber extraction 3 & LTE 3 & 168716 & 9833262 & 827 & W & 35.0 \\
\hline Large timber extraction 4 & LTE 4 & 170165 & 9834914 & 959 & ESE & 30.2 \\
\hline Agroforest 2 & AF 2 & 169333 & 9833896 & 952 & $\mathrm{E}$ & 20.6 \\
\hline Agroforest 3 & AF 3 & 169489 & 9834158 & 832 & NNW & 38.9 \\
\hline Agroforest 4 & AF 4 & 170737 & 9833172 & 806 & SSW & 37.1 \\
\hline Bariri & & 185479 & 9816446 & 1410 & - & 0.0 \\
\hline
\end{tabular}

rattan (Calamus spp.) or bamboo is collected, while the wana ngiki is considered untouched forest towards the peaks of the mountains (Helmi 2005). In the natural forest, up to 63 tree species (dbh $\geq 10 \mathrm{~cm}$ per $0.25 \mathrm{ha}$ ) were found where Meliaceae, Lauraceae, Sapotaceae, and Fagaceae had the highest share. The amount of endemic species and tree diversity decreased to 53 species per 0.25 ha after increased timber extraction (Gradstein et al. 2007).

\subsubsection{Site selection}

Following closely a multi-disciplinary approach, a number of participating projects were focused on different aspects of biodiversity and element cycles. Thus, all researchers were equally involved with the selection process as they were eventually expected to conduct their research on identical sites. Four different types of forest management were to be included: natural forest (NF), forest after large-diameter timber extraction (LTE), forest after small-diameter timber extraction (STE) and cacao agroforest under trees remaining from the natural forest (AF). Three replicates per forest use type were studied. A size of $30 \times 50 \mathrm{~m}$ was agreed to maintain equally sized plots as some cacao plantations did not exceed these dimensions. These plots were marked, measured and geo-referenced prior to the fitting of installations. Severely sloped sites received three paths parallel to the contour which were secured with rope. On the 12 plots, the slopes ranged between $17^{\circ}$ and $39^{\circ}$ and all expositions were represented (Table 2). 


\subsubsection{Bariri}

This study site lies in the Besoa region, in the eastern part of the Lore Lindu National Park, $\sim 12 \mathrm{~km}$ northwest from the village of Bariri (Table 2). As no settlements exist in the vicinity of the site, it can be reached by vehicle only under favorable road conditions or else on foot accompanied by buffalo-drawn carriages. The special feature of this site is a $70 \mathrm{~m}$ high meteorological scaffolding tower, erected amidst a stretch of natural forest, with ample infrastructural options for continuous sensor-based measurements in the forest canopy.

\subsubsection{Topography and climate}

The study site at the location of the meteorological tower in Bariri is situated at $\sim 1400 \mathrm{~m}$ asl on a level plateau, defined by a steep drop within $\sim 300 \mathrm{~m}$ to the north, west and south. The forest floor shows a mildly undulating micro-relief of $\sim 1 \mathrm{~m}$ difference, apparently created by pits of constantly falling trees and mounds of their slowly decomposing fragments.

The climatic conditions are markedly cooler than in Toro with a mean annual temperature of $19.4^{\circ} \mathrm{C}$ and drier with an annual precipitation of $1964 \mathrm{~mm}$. However, precipitation is well distributed over the year without a pronounced dry season (Fig. 4). Enhanced nocturnal cooling results in substantial amounts of dew fall and fog, particularly in the early morning hours.

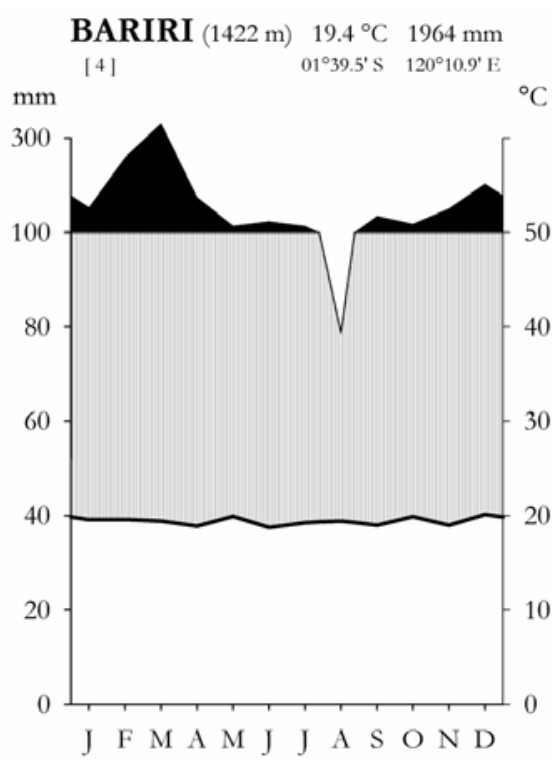

Fig. 4. Climate diagram after Walter et al. (1975) from data recorded at the automatic weather station in Bariri (Kreilein et al., unpublished data).

\subsubsection{Vegetation}

The natural forest in Bariri is richer in rattan (Calamus spp.) of which large tillers densely cover the forest floor and richer in epiphytic plants than the natural forests in Toro. The understorey contains a sparse layer of young tree individuals. With an estimated number of 100 to 150 tree species per hectare, the forest is highly diverse (Kessler et al. 2005). According to a recent inventory the dominant tree species with $12 \%$ of all individuals $\mathrm{dbh} \geq 7 \mathrm{~cm}$ is Castanopsis acuminatissima of the most abundant family Fagaceae (18\%), which is followed in abundance by Myrtaceae (13\%), Elaeocarpaceae (7\%), and Monimiaceae (7\%; Grote 2006). A $32 \mathrm{~m}$ high individual of Dacryodes spec., Burseraceae, (Culmsee, unpublished data) also reached the meteorological tower with its crown allowing sensor positioning within its foliage. The forest is a closed stand with a stem density of $557 \mathrm{ha}^{-1}(\mathrm{dbh} \geq 10 \mathrm{~cm})$, an average tree height of $24.7 \mathrm{~m}$ with the mean ramification starting at $12.2 \mathrm{~m}$. Except for small-scale disturbances in the understorey during the tower construction phase, the forest shows no signs of major anthropogenic impact. 


\subsection{Data Collection}

Rainfall data for this study were collected continuously from January 2004 until April 2005 in Toro which included two periods of intensive analysis per study site. Leaf wetness data were recorded from May 2004 until April 2005 in Bariri. The structural inventory was completed by August 2004.

\subsubsection{Inventory}

\subsubsection{Stand inventory}

On the forested sites, all trees with a diameter at breast height (dbh at $1.3 \mathrm{~m}$ ) of $10 \mathrm{~cm}$ or more were censused for dbh and height on the entire plot according to Kramer and Akça (2002). To account for smaller statured trees all individuals with $\mathrm{dbh}<10 \mathrm{~cm}$, but higher than $2 \mathrm{~m}$, were assessed on three randomly located subplots of $5 \times 5 \mathrm{~m}$ within the plot. In the agroforests, all stems taller than $2 \mathrm{~m}$ were censused. Measurement of dbh was done using a metric measuring tape, height measurements were taken with a Vertex III ultrasonic hypsometer (Haglöf, Långsele, Sweden). The crown projections of all 10 trees subject to stemflow measurements were recorded in 8 directions each. All censused trees were tagged with consecutive numbers at breast height. The basal area of highly fluted stems, e.g. mature individuals of Ficus spp., was approximated to a circular cross-section based on the measured circumference at breast height. Studies on 10 individuals showed that this resulted in a maximum overestimation of the true basal area of $5 \%$.

\subsubsection{Hemispherical photography}

Data on canopy structure was derived from hemispherical photographs (Fig. 5) which were obtained with a Nikon Coolpix 900 digital camera / Nikon FC-E8 fisheye converter of $2048 \times 1536$ pixel resolution mounted on a HemiView leveling device (Delta-T, Cambridge, UK). For reduction of horizon effects on the sloped sites, the device was consistently placed at $1.3 \mathrm{~m}$ above the ground. Thirty pictures per site and campaign were taken at the randomly located points of throughfall measurements (Fig. 6) on several occasions during the study period. Additionally, on one NF and AF plot each, 176 pictures were taken on a $3 \times 3 \mathrm{~m}$ grid (Fig. 6).

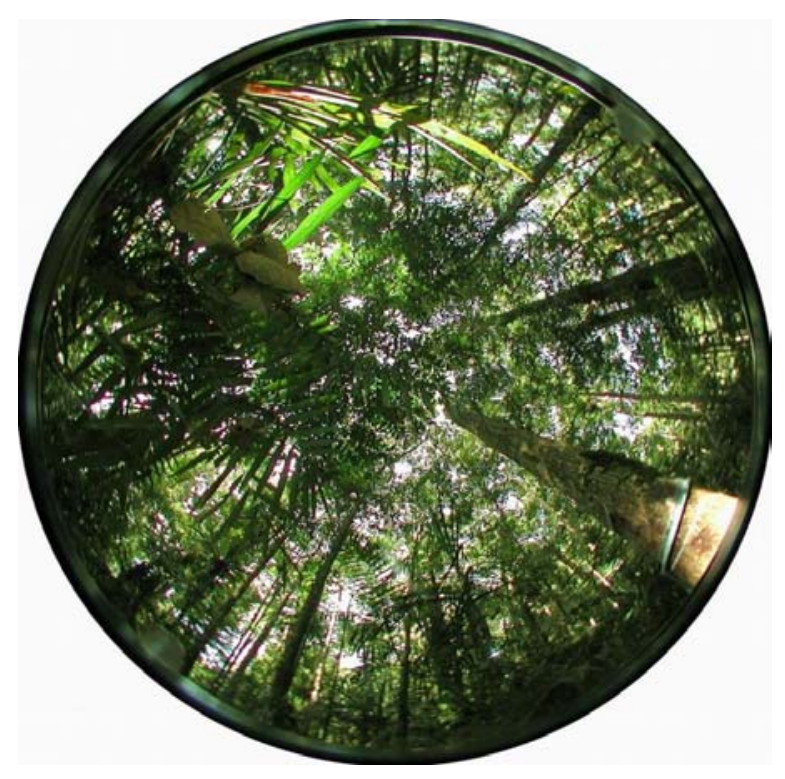

Fig. 5. Hemispherical photograph obtained from a natural forest site (NF 1) in Toro. 


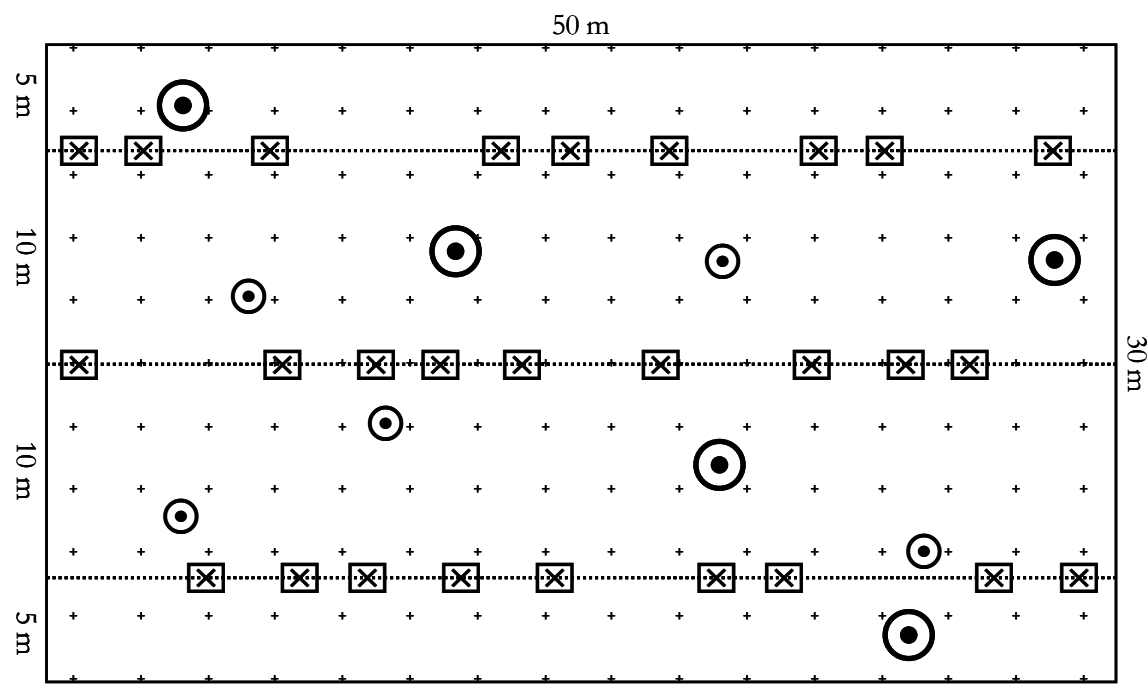

Fig. 6. Schematic setup of a study plot with the 3 parallel transects along each of which 10 throughfall gauges (囚) were positioned randomly. Stemflow $(\odot)$ was measured on 10 randomly chosen trees out of which 5 reached the upper canopy level and 5 were understorey trees. Indicated is the grid $(+)$ used in the roving gauge measurements.

\subsubsection{Rainfall measurements}

\subsubsection{Rainfall partitioning}

Gross precipitation $(\mathrm{Pg})$ was measured adjacent to each of the twelve study plots with five bulk samplers per location. The localities for the measurements of gross precipitation were within a $150 \mathrm{~m}$ range from the study plots, situated at the same altitude and had the same aspect. The gauges were placed at a height of $100 \mathrm{~cm}$ above ground in open areas where trees or other taller objects were more than $35 \mathrm{~m}$ away. In other cases, where the openings were smaller, the bulk samplers were placed on 5 to $7 \mathrm{~m}$ tall bamboo structures. The collectors had an orifice of $295 \mathrm{~cm}^{2}$ each and a vertical rim $3.5 \mathrm{~cm}$ high (Fig. 7). A table tennis ball was placed in each of the funnels to reduce evaporation from the gauges. During measurement campaigns in the adjacent forest plots the rainfall volumes were measured daily.

Daily measurements of throughfall (Tf) and stemflow (Sf) were conducted in each of the study plots during campaigns for periods of about 24 days to record 15 to 17 days with detectable incident rainfall which coincides with measuring periods by Manfroi et al. (2006). These campaigns were conducted between June 2004 and March 2005. The overall

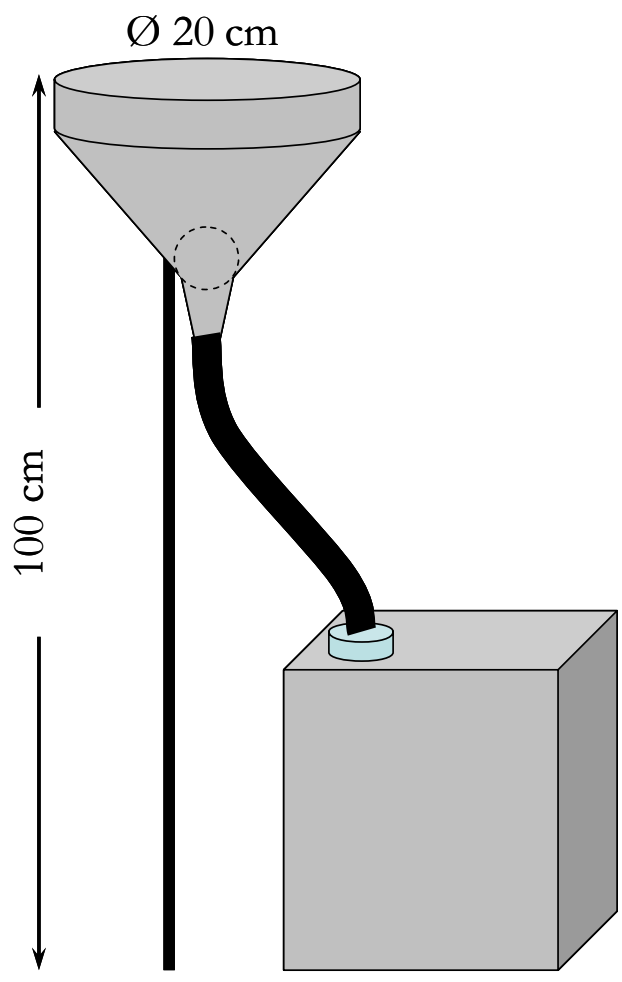

Fig. 7. Schematic sketch of a precipitation collector which was used to capture both gross precipitation and throughfall. 
measurement period for $T f$ and $S f$ with weekly readings at one permanent site per forest use type lasted from January 2004 until April 2005. Throughfall was collected with 30 funnels per plot that were built identically to the rain gauges described above. The throughfall gauges were arranged along three lines of each $50 \mathrm{~m}$ length, parallel to the contour with $10 \mathrm{~m}$ distance between the lines. On these lines the collector positions were defined by random with a minimum distance of $2 \mathrm{~m}$ between two samplers (Fig. 6). Single rainstorms (Table 1) were defined as events of $>0.2 \mathrm{~mm}$, separated from the succeeding event by a period of at least $2 \mathrm{~h}$ in agreement with Fleischbein et al. (2005).

Stemflow was measured using spiral collars attached to ten stems $(\geq 10 \mathrm{~cm}$ in $\mathrm{dbh}$ ) in each of the plots (Fig. 8). Five of these trees reached the upper tree layer while the remaining trees were smaller (Fig. 6). The trees of the upper tree layer were on average $29 \mathrm{~m}$ tall with a mean dbh of $45 \mathrm{~cm}$ while the sub-canopy trees were on average $22 \mathrm{~m}$ tall with a mean $\mathrm{dbh}$ of $15 \mathrm{~cm}$. Stemflow volumes per unit ground area for the $1500 \mathrm{~m}^{2}$ plots were estimated from linear regressions (intercept $=0$ ) between $\mathrm{dbh}$ and the $S f$ volume per volume of $P g$. These regressions were established from trees of the three plots belonging to the same forest use type (usually $n=30$ ). The volume of $S f$ significantly increased with dbh and the determinants of variation $\left(r^{2}\right)$ were 0.52 in the natural forest, 0.53 after small timber extraction, 0.34 after large timber extraction and 0.30 in the agroforest. For trees $\mathrm{dbh}<10 \mathrm{~cm}$ the regression lines were extrapolated and the $S f$ volume per plot area was calculated on the basis of measured dbh and stem density. Because the sugar palm Arenga pinnata exceeded the stemflow yield of dicotyledonous trees considerably, these three palms (one individual each in STE 2, STE 4, and AF 3) were always measured but not included into the regression analysis. Rather, where such palm was present in the research plot, its empirically determined stemflow volumes were directly added to the stemflow value which had been estimated for all remaining trees of the stand.

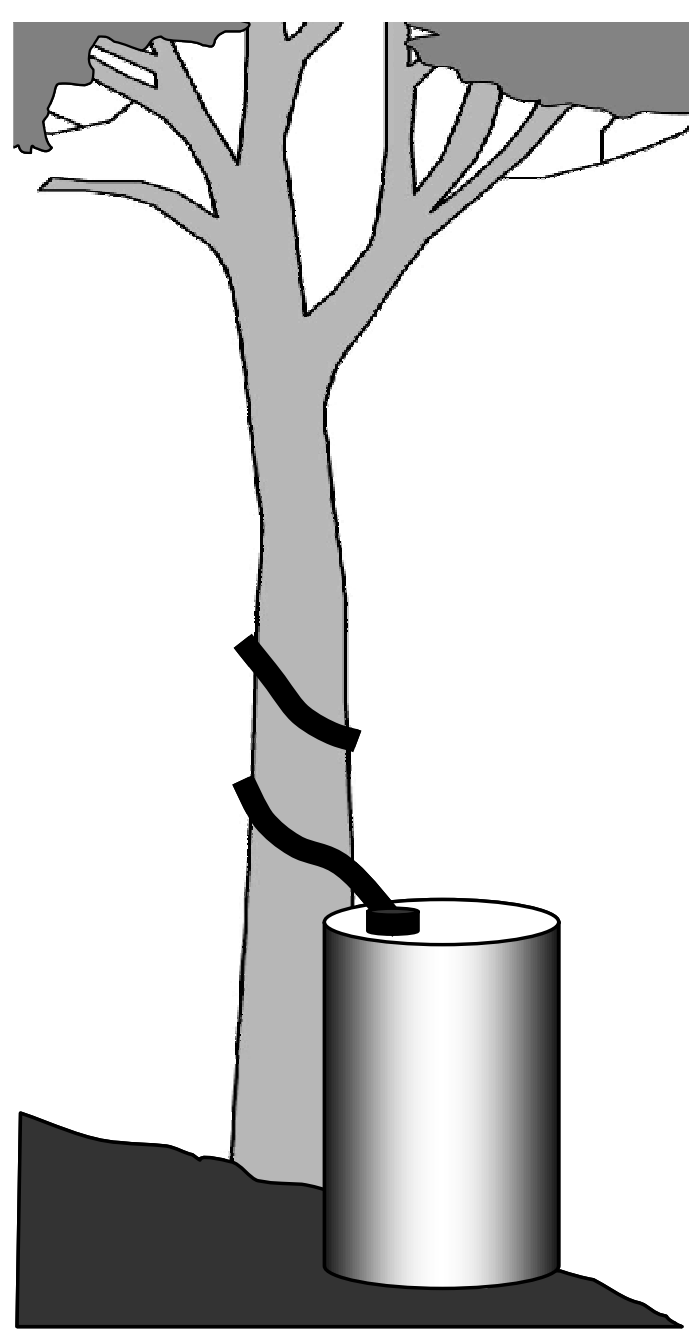

Fig. 8. Schematic sketch of a stemflow collection unit. A plastic hose was sliced open, mounted along the stem and sealed with silicone. The tube was attached to a container of $>100$ L capacity. 


\subsubsection{Leaf wetness}

Thirty surface wetness sensors of Skye Instruments Ltd. (Powys, UK) were used to estimate the duration of leaf surface wetness at different heights inside the forest. Wetness was recorded through changes in current output that occur when a DC circuit is shortcut by a water film on the surface of a gold-covered horizontal plate of $80 \times 80 \mathrm{~mm}$ in size (for more details see Letts and Mulligan 2005). The sensors were mounted on horizontal poles which allowed positioning them inside the tree canopies close to the leaves. We installed 30 sensors in $1.5 \mathrm{~m}$ intervals from 1.5 to $33 \mathrm{~m}$ above the ground. At 1.5, 3.0, 4.5, 6.0, 27.0, 28.5, 30.0, 31.5, and $33.0 \mathrm{~m}$ height, two sensors were operated in parallel to obtain average values of surface wetness. To allow for measurements in the undisturbed understorey, all wetness sensors below $6 \mathrm{~m}$ height were mounted $12 \mathrm{~m}$ east of the tower base which was devoid of understorey vegetation. Air temperature and air humidity were measured using radiation-shielded and ventilated dry and wet bulb thermometers (Friedrichs 3030.0000BG sensors, Theodor Friedrichs \& Co., Schenefeld, Germany). They were placed $2 \mathrm{~m}$ above ground on a separate weather station in the understorey $\sim 15 \mathrm{~m}$ southwest of the tower base. Inside the canopy, temperature and air humidity were measured at 22 and $36 \mathrm{~m}$ above ground on horizontal poles protruding $1.5 \mathrm{~m}$ from the north-eastern corner of the tower. Precipitation was recorded with two Friedrichs 7041.0000 ombrometers placed at a distance of $3 \mathrm{~m}$ to each other on the top of the tower at $69 \mathrm{~m}$ above ground.

Surface wetness data was recorded during a three-month period in 2004 using a CR10X logger combined with an AM16/32 relay multiplexer (both Campbell Scientific Inc., Shepshed, UK). Data was read from all 30 sensors in $15 \mathrm{sec}$ intervals and stored as $5 \mathrm{~min}$ means. Microclimate data was recorded separately at each height with a Friedrichs Kombilog 1020 logger (Theodor Friedrichs \& Co., Schenefeld, Germany). Sensors were scanned every $10 \mathrm{sec}$ and data was stored as 5 min means.

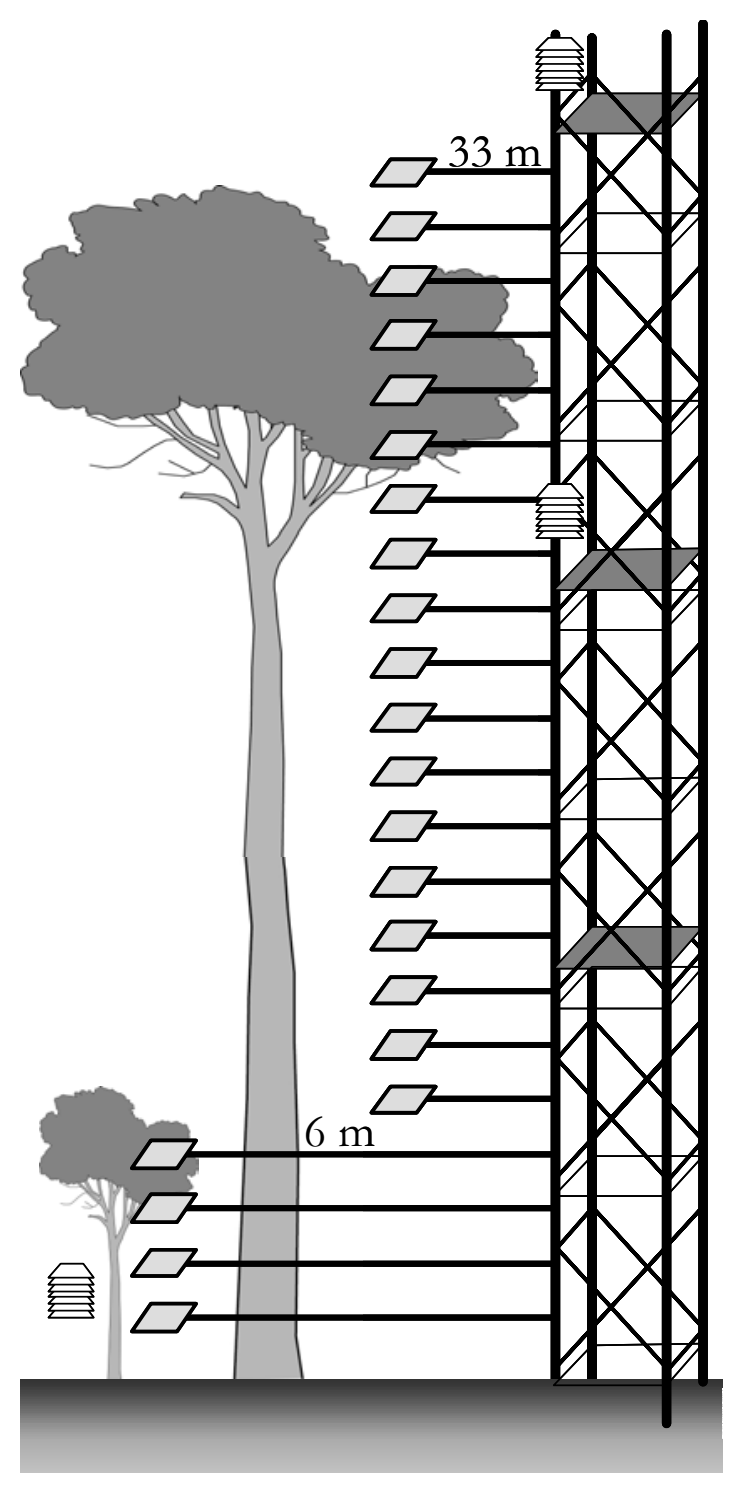

Fig. 9. Schematic sketch of the experimental setup for the leaf wetness measurements in Bariri. It included a vertical profile of surface wetness sensors within the canopy at an interval of $1.5 \mathrm{~m}$ where 3 automatically recording weather stations were available. 


\subsubsection{Data processing}

\subsubsection{Structure}

Raw structural data from the each research plot were related to three-dimensional terrain models to assist with corrections for edge and slope effects of e.g. stem density or basal area. Data on juvenile trees $\geq 2 \mathrm{~m}$ from the subplots were interpolated for the entire plot. For the agroforest sites where a full inventory had been conducted, the analysis of all structural parameters was additionally carried out separately for shade and cacao trees. Height curves were fitted to all stems $\mathrm{dbh} \geq 10 \mathrm{~cm}$ for each stands according to van Laar and Akça (1997). Leaf area index (LAI) was estimated for different dates in groups of 10 hemispheric pictures with CanEye 3.6 (INRA, Avignon, France; Weiss 2002) under standard conditions assuming a LAI saturation at 10 . Hemispheric photographs from the grid points were analyzed individually using WinScanopy 2004a (Régent Instruments Inc., Sainte-Foy, Canada) to obtain grid compatible LAI estimates. Canopy openness was explored under different opening angles from hemispheric photos also using WinScanopy 2004a, and eventually an opening angle of $30^{\circ}$ considered most appropriate.

Means of all parameters were calculated for each site and sites combined to means and medians for each forest use type. The coefficient of variance (cv) was examined for spatial variation in LAI and canopy openness. Where appropriate, means were compared using analysis of variance (one-way ANOVA), Duncan's test. Otherwise, distributions were compared using non-parametric tests (Wilcoxon, two-tailed). Significance was commonly set at $p<0.05$ unless specified otherwise.

\subsubsection{Rainfall partitioning}

Throughfall data were expressed per plot as the median of all 30 measurements per plot. It was directly expressed in percentage of $P g$ volumes. Missing daily $P g$ volumes were replaced by regressing weekly volumes against daily data from the automatic weather station or from daily data of another manually gauged station, whichever was closer to the point of measurement. For direct comparisons of plots, the sums of all collector readings over the given period were used. Stemflow data were interpolated with stand based regression models of $S f$ yields vs. dbh as described in section 2.2.2.1. As only three individuals of $A$. pinnata were encountered on the research plots, the input to stemflow by palms was calculated separately from direct measurements. Interception (I) was obtained as the difference of

$$
\boldsymbol{I}=\boldsymbol{P} \boldsymbol{g}-\boldsymbol{T} \boldsymbol{f}-\boldsymbol{S} \boldsymbol{P} \quad \text { (Equation 1) }
$$

Due to the use of medians in expressing throughfall, a direct comparison between study sites based on the two-tailed Wilcoxon signed rank test $(p<0.05)$ was supported by examination of the $25^{\text {th }}$ and $75^{\text {th }}$ percentile ranges. 
Using grid based throughfall data, the spatial variability of $T f$, its spatial autocorrelation and possible influences inferred by rainfall intensity and stand structural parameters were additionally explored using the Mantel test. The Mantel test is a commonly applied approach in vegetation sciences. Essentially, it is a regression in which the variables are dissimilarity matrices summarizing a pair-wise dissimilarity among samples. Thus dissimilarity matrices are established for values e.g. of throughfall percentages between all samples and for the geographical distances between their locations using the z-standardized Euclidean distance (d):

$$
d_{j k}=\sqrt{\sum_{i=1}^{n}\left(x_{i j}-x_{i k}\right)^{2}}
$$

where $x$ is a variable measured at locations $j$ and $k$.

The Mantel correlation is expressed by the coefficient ₹, based on the following calculation:

$$
z=\sum_{i=1}^{n} \sum_{j=1}^{n} x_{i j} \cdot y_{i j}
$$

This Mantel coefficient $z$ is subsequently normalized as $r$.

$$
r=\frac{1}{n-1} \cdot \sum_{i=1}^{n} \sum_{j=1}^{n} \frac{x_{i j}-\bar{x}}{s_{x}} \cdot \frac{y_{i j}-\bar{y}}{s_{y}} \quad \text { (Equation 4) }
$$

where $x$ and $y$ are variables measured at locations $i$ and $j$, and $n$ is the number of elements in the distance matrices $\left(=m \cdot(m-1): 2\right.$ for $m$ sample locations), and $s_{x}$ and $s_{y}$ are standard deviations for variables $x$ and $y$. This standardized equation (4) allows one to consider variables of different measurement units within the same framework, rescaling the statistics to the range of a conventional correlation coefficient bounded on [-1,1]. In practice, a negative Mantel's correlation is rare. The magnitude of correlation is often comparatively small even when highly significant statistically (Urban 2003).

Because the elements of a dissimilarity matrix are not independent, the significance of the Mantel test is evaluated via permutation procedures. The rows and columns of the dissimilarity matrices are randomly rearranged. Mantel statistics are recomputed for these permuted matrices, and the distribution of values for the statistics is generated via many iterations $(\sim 1000$ for $\alpha=0.05, \sim 5000$ for $\alpha=0.01, \sim 10000$ for greater precision) (Legendre 2000).

The simple Mantel test was used for assessing spatial autocorrelation parameters from grid based measurements such as throughfall, leaf area index, and canopy openness. The partial Mantel test, however, allows further comparison among three dissimilarity matrices $\left(X_{1}, X_{2}, X_{3}\right)$. It estimates the correlation between two matrices $\left(X_{1}, X_{2}\right.$, e.g. Tf and LAI) and controls the effect of the third $\left(X_{3}\right.$, e.g. geographical distance). The test statistics are calculated by constructing a matrix of residuals, $X_{1}$, of the regression between $X_{1}$ and $X_{3}$, and a matrix of residuals, $X_{2}$, of 
the regression between $X_{2}$ and $X_{3}$. The two residual matrices, $X_{1}{ }^{\prime}$ and $X_{2}{ }^{\prime}$ are then compared by a standard (simple) Mantel test as in:

$$
r\left(x_{1} x_{2} x_{3}\right)=\frac{r\left(x_{1} x_{2}\right)-r\left(x_{1} x_{3}\right) \cdot r\left(x_{2} x_{3}\right)}{\sqrt{1-r\left(x_{1} x_{3}\right)^{2}} \cdot \sqrt{1-r\left(x_{2} x_{3}\right)^{2}}}
$$

where $x_{1}, x_{2}$ and $x_{3}$ are random variables. The value $r\left(x_{1} x_{2} \cdot x_{3}\right)$ measures the partial correlation between $x_{1}$ and $x_{2}$ when $x_{3}$ is held constant (Legendre 2000).

\subsubsection{Leaf wetness}

Gaps of recording were identified in raw leaf wetness data. At profile levels where $>1$ sensor was deployed data gaps were closed using the values from the functional sensor when possible. Otherwise, the average value of all sensors from the same profile level was used. Data output by the sensors was in $\mathrm{mV}$ and did not sufficiently account for gradual changes of surface wetness. Rather, the point of complete drying was characterized as a marked drop in voltage. Thus, the threshold for dry conditions was set at below $250 \mathrm{mV}$ which corresponded well to $50 \%$ of the maximum output value under wet conditions. Data intervals were maintained at a 5 min resolution throughout the analysis. For interpretation, each sensor value represented the $1.5 \mathrm{~m}$ zone below its height above ground, which corresponded to the distance to the sensor below.

The leaf wetness profile was completed by micrometeorological data which was obtained from standard observations on the tower at three different heights. Data on air temperature $\left(T_{a}\right)$ and relative air humidity $(r H)$ permitted the calculation of the atmospheric saturation deficit $(\Delta e)$ and the dew point temperature $\left(T_{D P}\right)$. With data from three different heights it was attempted to describe the vertical profiles of all abovementioned parameters and to relate them to the leaf moisture profile. Rainfall data from the top of the tower was essential in aligning leaf wetness with recorded, substantial precipitation to demonstrate the time lag between first responses to rainfall between both sensor types of different sensitivity. 


\section{Results and Discussion}

\subsection{Different Forest Use and Forest Structure}

One main focus of the interdisciplinary project STORMA, in which this study was imbedded, was on the change that human intervention in tropical rainforest margins causes on ecosystem structures and functions. Of special interest were hydrological processes (Keil et al. 2003, Dietz et al. 2006), nutrient budgets, carbon pools such as below-ground biomass (Leuschner et al. 2006), as well as parameters of biodiversity in flora and fauna (Bos et al. 2007, Gradstein et al. 2007, Migge-Kleian et al. 2007). An overarching concept of all approaches was the existence of a gradient in land and forest use intensity within the margin zone of the Lore Lindu National Park (LLNP).

\subsubsection{Traditional forest use}

The traditional forest use in the studied region of Toro has been endorsed by the head of the LLNP (Helmi 2005). The system of land use practiced in the village of Toro divides the region, particularly the forested slopes surrounding the valley, into five distinct zones. The wana ngiki, is the 'forest towards the peak of the mountain that is far away' and does not receive any lasting human intervention; the wana is an old growth forest that has never been developed as agricultural land and serves only as source for occasional rattan extraction and as hunting grounds; the pangale is the mountain forest which is old-growth forest which is often subject to logging of different scales; the pabawa pongko is abandoned agricultural land or freshly acquired forest for agricultural use; and the oma is frequently cultivated land of agroforestry. This study focused mainly on natural forest (NF) from the wana zone, contrasting sites from the pangale zone which had been subject to extraction of small diameter timber for local use (STE) or more extensive selective logging of large diameter timber for construction (LTE), and cacao agroforestry (AF) in the pabawa pongko zone, where cacao trees are planted under the sparse canopy of trees remaining from the natural forest.

Much attention was paid to the selection of the individual study sites as on one hand the approach called for repetitions of each sampled forest use type and on the other hand agreement had to be reached among all the participating research projects. Most challenging, however, was to identify homogeneous sites of comparable size and quality in terms of edaphic conditions, topography and their history of use. In this context, there existed apparently no common practice on how a cacao agroforest is traditionally managed in terms of which and how many shade trees are to be maintained. Furthermore, structural characteristics after similar logging impacts differed considerably, particularly in the lower forest strata, depending on how long this intervention dated back. Although heterogeneity between sites could not be entirely eliminated, at least three comparable sites were identified for each investigated forest use type. 


\subsubsection{Stand structural parameters}

\subsubsection{Stem density}

Koop et al. (1995) recognized the density of large trees as a good estimator for human influence on Sumatran rainforests. On the study sites around Toro, the density of large stems with a diameter at breast height (dbh) larger than $50 \mathrm{~cm}$ also appeared to be a good indicator of the intensity of forest use (Fig. 10, solid bars). Highest values with a median of 71 and 72 stems $(\mathrm{dbh} \geq 50 \mathrm{~cm})$ per hectare were found in the natural forest and in forest after small timber extraction. Large timber extraction reduced the density to 55 stems per hectare (median). Agroforests contained only 25 large trees per hectare (ranging between 6 and 51 stems per hectare, Table 3). The very large variability in the density of large-diameter stems in the agroforestry systems may be related to the personal experience and preference of the different plot owners. A similar structural diversity in agroforestry systems was previously documented for other tropical regions by Ruf and Schroth (2004). Small stems $(\mathrm{dbh}<10 \mathrm{~cm})$ reached a median of 1800 stems per hectare in the natural forest, but were more abundant after large timber extraction (Fig. 10, hatched bars). In the gaps created by logging of big trees, abundant regrowth occurred with a median of $\sim 3400$ stems per hectare. In the agroforest, the class of small stems included most of the planted cacao trees.

\subsubsection{Basal area and stand height}

The abundance of large-diameter stems is known to be a good estimator of a stand's basal area (McElhinny et al. 2005). Basal areas with a median of 48 and $49 \mathrm{~m}^{2}$ per hectare in the natural

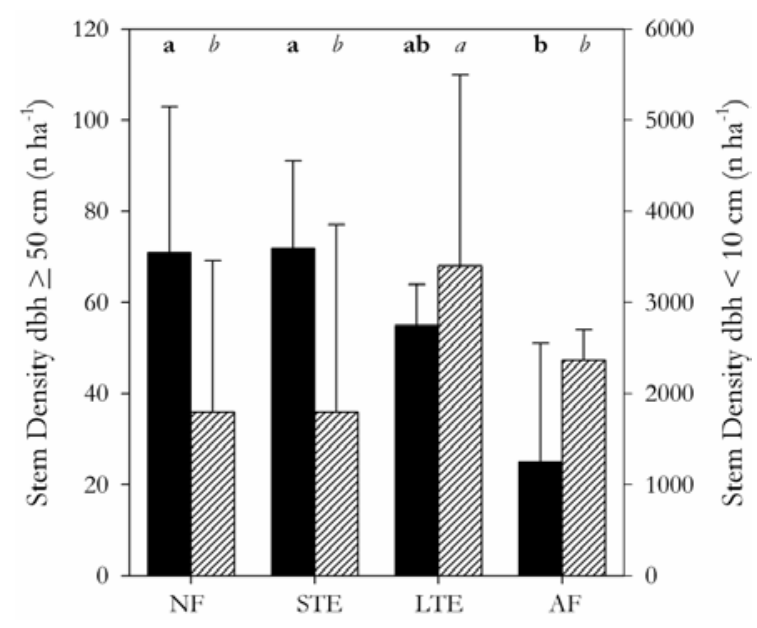

Fig. 10. Stem densities as the median in four different forest use types with maximum values. Number of all stems with diameter at breast height $(\mathrm{dbh}) \geq 50 \mathrm{~cm}$ (solid bars, left) and $\mathrm{dbh}<10 \mathrm{~cm}$ per hectare (hatched bars, right)

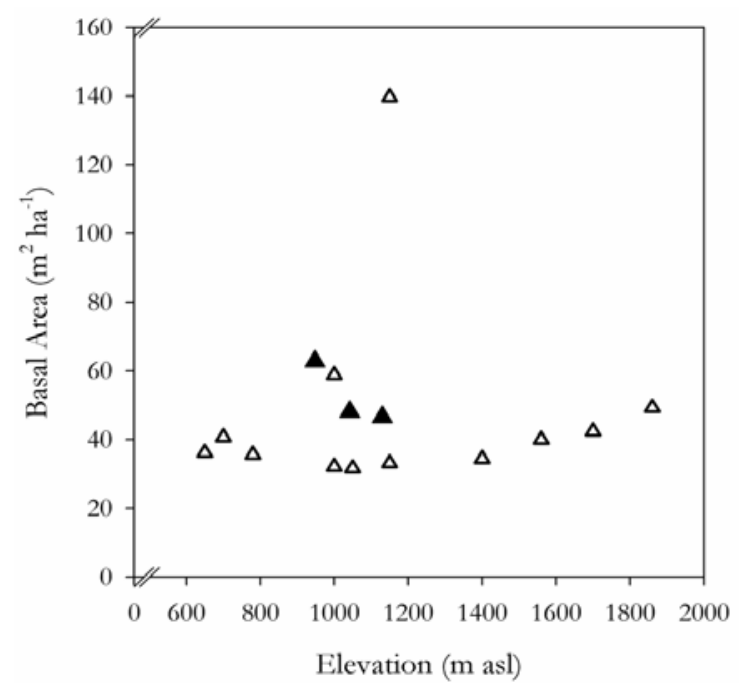

Fig. 11. Basal area of natural forests in the region of Toro, Central Sulawesi (this study, $\mathbf{\Delta}$ ), compared to results from other studies in natural forests of South East Asia $(\Delta)$ above $600 \mathrm{~m}$ asl.

Sources: Aiba and Kitayama 2002, Brodbeck 2004, Dietz et al. unpubl. data, Hamann et al. 1999, Kessler et al. 2005, Kitamura et al. 2005, Sri-Gernyuang 2003. 
Table 3. Aboveground forest structure in the study stands.

\begin{tabular}{|c|c|c|c|c|c|c|c|c|c|c|c|c|c|}
\hline \multirow{2}{*}{$\begin{array}{l}\text { Forest } \\
\text { use } \\
\text { type }\end{array}$} & \multicolumn{3}{|c|}{ Stem density $\left(\mathrm{n} \mathrm{ha}^{-1}\right)$} & \multicolumn{2}{|c|}{$\begin{array}{l}\text { Basal area } \\
\left(\mathrm{m}^{2} \mathrm{ha}^{-1}\right)\end{array}$} & \multirow{2}{*}{$\begin{array}{l}\mathrm{dbh} \\
(\mathrm{cm}) \\
\\
\mathrm{dbh} \geq \\
10 \mathrm{~cm}\end{array}$} & \multirow{2}{*}{ 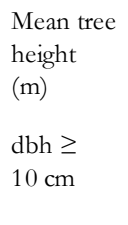 } & \multirow{2}{*}{$\begin{array}{l}\text { Stand mid } \\
\text { height } \\
(\mathrm{m}) \\
\text { Mean } \\
\text { dbh }\end{array}$} & \multirow{2}{*}{ 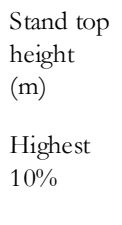 } & \multirow{2}{*}{$\begin{array}{l}\text { Crown } \\
\text { extension } \\
\text { (m) } \\
\mathrm{dbh} \geq \\
10 \mathrm{~cm}\end{array}$} & \multirow{2}{*}{$\begin{array}{l}\text { Lower } \\
\text { crown } \\
\text { limit }(\mathrm{m}) \\
\mathrm{dbh} \geq \\
10 \mathrm{~cm}\end{array}$} & \multirow{2}{*}{$\begin{array}{l}\text { Leaf area } \\
\text { index } \\
\left(\mathrm{m}^{2} \mathrm{~m}^{-2}\right) \\
(n=30)\end{array}$} & \multirow{2}{*}{$\begin{array}{l}\text { Canopy } \\
\text { openness } \\
(\%) \\
(n=30)\end{array}$} \\
\hline & $\overline{\text { All ster }}$ & $\begin{array}{l}\mathrm{dbh} \\
\geq 10 \\
\mathrm{~cm}\end{array}$ & $\begin{array}{l}\mathrm{dbh} \geq \\
50 \mathrm{~cm}\end{array}$ & $\begin{array}{l}\begin{array}{l}\text { All } \\
\text { stems }\end{array} \\
\end{array}$ & $\begin{array}{l}\mathrm{dbh} \geq \\
10 \mathrm{~cm}\end{array}$ & & & & & & & & \\
\hline NF 1 & 2272 & 472 & 103 & 68.6 & 62.8 & 30.3 & 21.9 & 25.1 & 42.9 & 9.2 & 12.7 & $5.7^{\mathrm{ab}}$ & 9.7 \\
\hline NF 4 & 1806 & 406 & 58 & 50.0 & 48.1 & 31.5 & 22.9 & 26.7 & 47.6 & 11.6 & 11.4 & $6.4^{\text {a }}$ & 9.3 \\
\hline NF 5 & 3455 & 655 & 71 & 51.1 & 46.6 & 26.7 & 19.2 & 21.5 & 35.8 & 7.6 & 12 & $6.5^{\mathrm{a}}$ & 10.9 \\
\hline STE 2 & 2020 & 620 & 61 & 55.7 & 43.5 & 26.8 & 18.7 & 20.7 & 35.1 & 8.4 & 10.5 & $4.3^{\mathrm{de}}$ & 7.7 \\
\hline STE 3 & 3855 & 655 & 91 & 67.0 & 62.7 & 29.5 & 19.2 & 22.5 & 37.5 & 8.5 & 11 & $6.3^{\mathrm{a}}$ & 7.0 \\
\hline STE 4 & 2420 & 620 & 72 & 41.4 & 48.7 & 23.2 & 16.3 & 18.4 & 35.3 & 7.7 & 9.1 & $5.2^{\mathrm{bc}}$ & 6.4 \\
\hline LTE 1 & 5495 & 695 & 25 & 41.1 & 34.9 & 20.4 & 15.1 & 16.8 & 33.2 & 7.5 & 9.4 & $4.9^{\mathrm{bcd}}$ & 12.9 \\
\hline LTE 3 & 3740 & 740 & 64 & 53.6 & 50.1 & 25.9 & 18.3 & 21.3 & 37.0 & 7.2 & 11.3 & $4.9^{\mathrm{cd}}$ & 8.2 \\
\hline LTE 4 & 4052 & 652 & 55 & 34.6 & 30.2 & 22.1 & 16.8 & 18.7 & 27.1 & 6.5 & 10.3 & $5.2^{\mathrm{bc}}$ & 9.3 \\
\hline AF 2 & 1706 & 125 & 6 & 8.6 & 8.5 & 25.6 & 14.7 & 15.9 & 28.4 & 5.8 & 8.9 & $5.7^{\mathrm{ab}}$ & 19.7 \\
\hline $\mathrm{AF} 3$ & 2705 & 237 & 25 & 23.7 & 23.4 & 32.7 & 18.9 & 20.6 & 35.7 & 9.7 & 9.6 & $6.3^{\mathrm{a}}$ & 15.9 \\
\hline $\mathrm{AF} 4$ & 2612 & 247 & 51 & 26.5 & 26.3 & 38.1 & 19.0 & 19.9 & 35.0 & 7.9 & 12.1 & $4.1^{\mathrm{e}}$ & 9.8 \\
\hline Bariri & 6557 & 557 & 65 & 39.1 & 34.3 & 25.1 & 21.8 & 24.7 & 36.0 & 9.2 & 12.6 & 5.4 & 14.9 \\
\hline
\end{tabular}

Values representing the median for each forest type are printed in bold. Significantly different means between LAI values per stand ( $\mathrm{n}=30$ photos per stand) are indicated by different lower case letters (analysis of variance, $p<0.05$ ).

forest and in stands after small timber extraction, respectively, seemed to be relatively high, especially when the peak value of $62.8 \mathrm{~m}^{2} \mathrm{ha}^{-1}$ was considered. However, a comparison with other studies in natural forests above $600 \mathrm{~m}$ asl in the South East Asian region revealed that the values for the natural forests in Toro were indeed slightly above the average, yet they were still within the reported range (Fig. 11).

In our study region, the median of basal area $(\mathrm{dbh} \geq 10 \mathrm{~cm})$ decreased to $35 \mathrm{~m}^{2} \mathrm{ha}^{-1}$ in stands after large timber extraction and dropped to $23 \mathrm{~m}^{2} \mathrm{ha}^{-1}$ in the agroforest. The decrease in tree basal area along the gradient of use intensity was paralleled by a decrease in tree height. The stand mid height, which is the height of a tree with the arithmetic mean of dbh (Kramer and Akça 2002), decreased from $25 \mathrm{~m}$ (median) in the natural forest and from $21 \mathrm{~m}$ in stands after small timber extraction to $19 \mathrm{~m}$ in stands after large timber extraction and $20 \mathrm{~m}$ in the agroforest. The relatively high mean dbh in agroforests, in comparison to all other stands, is an effect of only large remaining trees which dominated the class of $\mathrm{dbh} \geq 10 \mathrm{~cm}$. The apparent drop in tree mean height between natural forest and forest after small timber extraction is statistically not significant on the level of forest use types. If existent, it may also be caused by differences in environmental conditions between sites comparable e.g. to those observed by Takyu et al. (2002) in old-growth forests on Mt. Kinabalu, Borneo. 


\subsubsection{Leaf area index and canopy openness}

Leaf area index (LAI) is a basic variable for modeling the energy and matter fluxes in forests; this parameter is also of great importance for vegetation models in the context of global change research (e.g. Asner et al. 2003). A variety of different assessment methods are used in the field (Breda 2003, Jonckheere et al. 2004). A consistent underestimation of LAI by indirect methods such as hemispheric photography was reported by Breda (2003) but it was acknowledged that rapid technical and methodological advances were currently improving the precision of such estimates. On the global scale, Asner et al. (2003) confirmed that indirect optical measurements of LAI were closer to the results from destructive assessments than interpolations derived from litter sampling or estimates obtained through allometric functions. The destructive sampling approach would have been very labor-intensive and would have conflicted with conservation policies of the LLNP, where most forest plots were located. Since hemispheric photography is a rapid, sufficiently reliable and non-destructive approach for the assessment of canopy structure (Jonckheere et al. 2004), it was thus chosen in this study.

The LAI of evergreen forests may change seasonally with rainfall volumes and other climatic parameters (Asner et al. 2003, Breda 2003). Therefore, we analyzed most stands for their leaf area at three different points of time. However, in none of the stands, a distinct seasonality in LAI was observed (see Fig. 12 for the LAI of a natural forest). This may be due to the largely a-seasonal rainfall distribution in the study region. The following results are based on photos taken during a measurement campaign in April 2005.

The LAI as derived from 30 photos of the natural forest stands in Sulawesi ranged between 5.7 and $6.5 \mathrm{~m}^{2} \mathrm{~m}^{-2}$. In their global review, Asner et al. (2003) reported a mean ( $\pm \mathrm{SD}$ ) LAI of 4.9 (2.0) for tropical evergreen broadleaf forests. Aragão et al. (2005) found values between 3.6 and 6.6 for natural forests in Amazonia, Trichon et al. (1998) reported values between 3.9 and 6.1 from rainforests in Sumatra, and similarly Kumagai et al. (2004) found values between 4.8 and 6.8
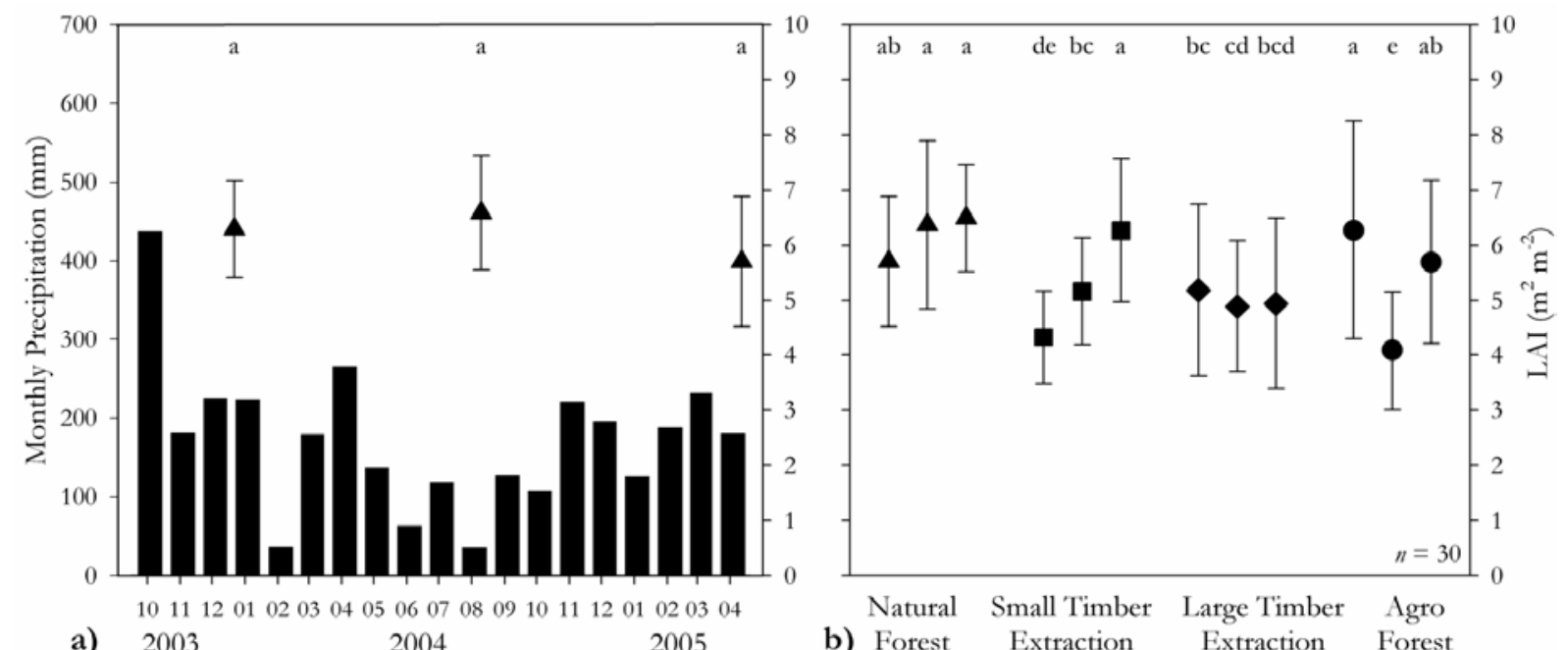

Fig. 12. Leaf area index (LAI) estimates from a natural forest on three different dates compared to the monthly rainfall volumes (a), and LAI values with standard deviation for all twelve plots grouped by forest use types (b). ( $\mathrm{n}=30$ photos per stand, analysis of variance, Duncan's test $p<0.05$ ). 
in Borneo. Roberts et al. (2004) collected LAI values ranging between 4.1 and 8.0 for tropical lowland rainforests with a tendency of higher values in Asia. Thus, the values obtained in Sulawesi are well within the range of other studies and they may also support slightly higher values in Asian tropical forests (Roberts et al. 2004).

The LAI varied within a plot only moderately in space. In the natural forest, the coefficient of variation (cv) ranged between 15 and 24\% which is similar to results found in natural forests of the Brazilian Amazon using a different, yet quite comparable method (Licor LAI 2000; Aragão et al. 2005). In our study region, the $c v$ values in forest stands after large timber extraction and the agroforest stands ranged between 24 and 32\%. This corresponds with cvs measured in Amazonian secondary forests (Aragão et al. 2005). The variation among plots of the same use type was largest in the agroforestry systems, where values between 4.1 and 6.3 were observed. The large variability among the agroforest sites may be explained with the already mentioned densities of large and small stems that differ greatly under permanent human influence (Ruf and Schroth 2004). Our relatively high average LAI values for agroforest confirm studies claiming that tree plantations in general (Asner et al. 2003), and cacao in Central Sulawesi in particular (Falk 2004), can maintain a comparably large leaf area. The relatively high LAI values in managed stands of Sulawesi compare well with results from Amazonia where only little differences in LAI between natural forests and selectively logged sites were observed (Aragão et al. 2005). The high proportion of regrowth after large timber extraction may contribute substantially to such high LAI values in Sulawesi.

The canopy openness, as determined from photographs taken at $1.3 \mathrm{~m}$ above the ground, was between 9 and $11 \%$ per site in the natural forest; it was considerably higher in cacao agroforest (between 10 and 20\%; Table 3). The values obtained in the forest stands after small and large timber extraction did not differ significantly from those in the natural forest. Trichton et al. (1998) found canopy openness values below 10\% in mature Sumatran rainforests but they report much larger values for gap phases. Tobón Marin et al. (2000) found canopy openness values from 9 to $17 \%$ in natural rainforests of western Amazonia. In the agroforest systems of Sulawesi, many large trees have been removed arbitrarily and to different extents by the plantation owners who subsequently planted crop trees in different densities. Thus, in the agroforest, we found the highest average canopy openness which was associated with a relatively high spatial variation in this parameter in a given stand and among different stands (Table 3). 


\subsection{Rainfall Partitioning}

\subsubsection{Intensive campaigns}

During the intensive measurement campaigns which comprised of 15 to 17 rain days each with daily measurements, a mean gross rainfall of $228 \mathrm{~mm}$ was observed (range: $148-480 \mathrm{~mm}$ ). In the four forest use types, the median of throughfall was lowest in natural forest $(70 \%$ of $P g)$, and similarly high in all other use types (79 to $81 \%$; Table 4).

Stemflow, also accounting for the exceptionally high input by sugar palms (Arenga pinnata), was estimated with less than $1 \%$ of $P g$ in all studied use types. A similarly low stemflow fraction has also been observed in most tall old-growth forests, both in montane (Steinhardt 1979) and lowland settings (Lloyd et al. 1988, Ubarana 1996, Tobón Marin et al. 2000). Our value was slightly below that observed in a lowland forest in Sarawak where stemflow was estimated at 3\% of Pg (Manfroi et al. 2004) which may be due to the better representation of small statured trees in that stand. In our estimate, an average of $\sim 40 \%$ of all stemflow was contributed by stems smaller than $10 \mathrm{~cm}$ in diameter. Arenga pinnata had 3-fold higher stemflow yield than dicotyledonous trees of the same size, but only three individuals of these trees were encountered (one individual each in STE2, STE4, and AF3; see Table 4). The observation, that palms may have higher stemflow values than co-occurring trees has also been reported from other forest stands (Jordan and Heuveldop 1981, Lloyd et al. 1988). A contribution of thin stems (dbh $<10 \mathrm{~cm})$ to stemflow generation far above the average was calculated with $>50 \%$ only in one LTE and in all agroforest sites.

Table 4. Rainfall partitioning in the 12 study plots.

\begin{tabular}{|c|c|c|c|c|c|c|c|c|c|}
\hline & \multirow{2}{*}{$\begin{array}{l}\text { Number of } \\
\text { rainy days }\end{array}$} & \multirow{2}{*}{$\begin{array}{l}\text { Gross } \\
\text { precipitation }(\mathrm{mm})\end{array}$} & \multicolumn{3}{|c|}{ Throughfall $^{\mathrm{a}}(\%$ of $P g$ ) } & \multicolumn{3}{|l|}{ Stemflow } & \multirow{2}{*}{$\begin{array}{l}\text { Interception } \\
(\% \text { of } P g)\end{array}$} \\
\hline & & & $25^{\text {th }}$ & Median & $75^{\text {th }}$ & (\% of $\mathrm{Pg})$ & $\frac{\mathrm{dbh} \geq 10 \mathrm{~cm}}{\mathrm{dbh}<10 \mathrm{~cm}}$ & $\begin{array}{l}\text { Input by } \\
\text { palms (\%) }\end{array}$ & \\
\hline NF 1 & 18 & 215 & 37.3 & $46.6^{\mathrm{d}}$ & 55.3 & 0.6 & 1.4 & 0.0 & 52.8 \\
\hline NF 4 & 17 & 165 & 52.2 & $69.8^{\mathrm{c}}$ & 79.0 & 0.3 & 2.2 & 0.0 & 29.9 \\
\hline NF 5 & 17 & 148 & 71.8 & $81.9^{\mathrm{b}}$ & 95.6 & 0.5 & 1.6 & 0.0 & 17.6 \\
\hline STE 2 & 16 & 480 & 53.5 & $70.7^{\mathrm{c}}$ & 82.8 & 0.7 & 1.8 & 2.4 & 28.6 \\
\hline STE 3 & 16 & 315 & 68.1 & $79.1^{\mathrm{ab}}$ & 101.8 & 0.9 & 1.9 & 0.0 & 20.0 \\
\hline STE 4 & 16 & 300 & 80.9 & $92.5^{\mathrm{a}}$ & 97.0 & 0.6 & 2.7 & 13.8 & 6.9 \\
\hline LTE 1 & 15 & 220 & 59.1 & $86.7^{\mathrm{ab}}$ & 107.3 & 0.7 & 0.9 & 0.0 & 12.6 \\
\hline LTE 3 & 15 & 185 & 67.4 & $80.2^{\mathrm{b}}$ & 94.3 & 0.7 & 2.1 & 0.0 & 19.1 \\
\hline LTE 4 & 15 & 259 & 67.8 & $80.3^{\mathrm{ab}}$ & 108.5 & 0.6 & 1.2 & 0.0 & 19.0 \\
\hline $\mathrm{AF} 2$ & 18 & 293 & 79.0 & $100.5^{\mathrm{a}}$ & 111.1 & 0.7 & 0.8 & 0.0 & -1.2 \\
\hline $\mathrm{AF} 3$ & 17 & 172 & 68.7 & $81.2^{\mathrm{b}}$ & 100.2 & 0.9 & 1.0 & 19.0 & 17.9 \\
\hline $\mathrm{AF} 4$ & 18 & 214 & 48.2 & $64.2^{\mathrm{c}}$ & 86.2 & 1.0 & 1.0 & 0.0 & 34.8 \\
\hline
\end{tabular}

Values representing the median for each forest type are printed in bold. Significantly different means between research sites ( $\mathrm{n}=30$ rainfall gauges per plot) are indicated by different lower case letters (Wilcoxon signed ranks test, two-tailed, $p<0.05$ ).

a Shown are the $25^{\text {th }}, 50^{\text {th }}$ (median), and $75^{\text {th }}$ percentiles. 
Although considerable variability was observed in throughfall within stands of the same use type (Fig. 13), the resulting interception was highest in the natural forest where 30\% (median) of $\mathrm{Pg}$ were re-evaporated back into the atmosphere, and much lower in forest plots under management (18 to $20 \%$ of $P g$ ). The calculated rainfall interception in the twelve plots ranged from $53 \%$ in a natural forest to virtually none $(-1 \%$ of $P g)$ in an agroforest. As our measurement scheme for throughfall and stemflow seemed quite robust, a likely source of error leading to negative values for interception was the less reliable measurement of gross precipitation which has been a problem in many studies (Crockford and Richardson 2000). For example, wind driven rain and contrasting atmospheric turbulence patterns above the stand and above the clearing may have caused a bias in the $P g$ data. Fog was rarely observed to form on the lower slopes around the Toro valley where the study plots where located (pers. observ.). Thus, it is unlikely that intercepted fog may have contributed to exaggerated throughfall volumes on the study sites in question. In the present study, sources of error could not be distinguished, thus it was preferred to maintain the full observed data variability of results in the further analyses.

On this basis, the data suggested that rainfall interception was reduced by logging from $30 \%$ to $18 \%$ of $\mathrm{Pg}$. This shift confirms earlier results in a lowland forest in Kalimantan, where the rainfall interception was 11\% in a natural forest and $6 \%$ in a logged forest (Asdak et al. 1998). On the other hand, data from this study seem to conflict with observations from Sabah, where interception was estimated with $8 \%$ of $P g$ in an undisturbed forest and with 15\% and $19 \%$ of $P g$ in a logged forest (Chappell et al. 2001). In both studies, alterations in tree height and associated canopy roughness lengths by logging were seen as the major cause of the change in rainfall partitioning. Canopy roughness may influence the exchange of water and energy with the atmosphere and may lead to enhanced interception (Asdak et al. 1998) but can probably also increase the net rainfall volume (Chappell et al. 2001). Considering the existing studies it thus appears difficult to draw general conclusions on the effects of logging on rainfall partitioning.

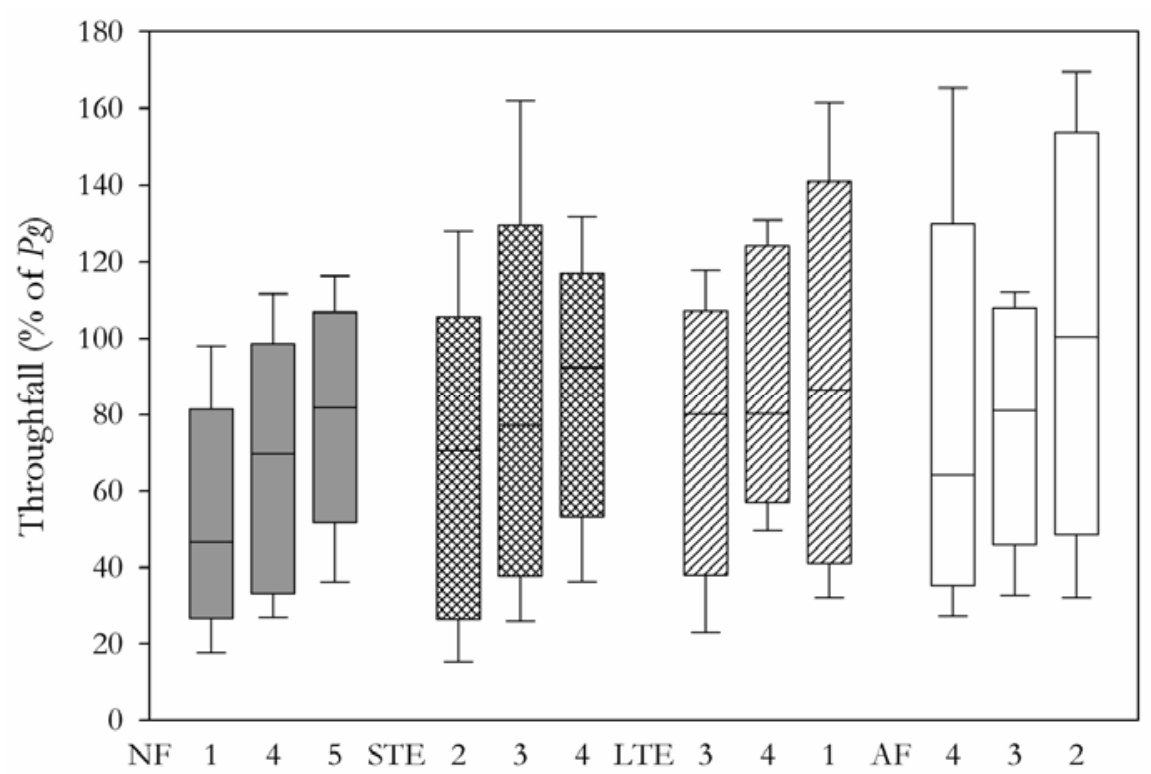

Fig. 13. Range and variability of throughfall measurements during the intensive campaign in 12 differently used forest stands in the Toro region. Three plots each were sampled from natural forest (NF, solid), after small timber extraction (STE, cross-hatched), large timber extraction (LTE, hatched) and agroforest (AF, open). Displayed are the $5^{\text {th }}, 25^{\text {th }}$, $50^{\text {th }}$ (median), $75^{\text {th }}$, and $95^{\text {th }}$ percentiles. 


\subsubsection{Long-term monitoring}

An observation of rainfall partitioning over longer periods is suggested where seasonal changes in rainfall or vegetation structure are to be expected (van Dijk and Bruijnzeel 2001b, Hölscher et al. 2004, Manfroi et al. 2006). During the long term observations in this study, where one selected plot from each forest use type (NF1, STE2, LTE4, AF3) was monitored for more than 60 weeks, the measured $P g$ ranged from 3189 to $4360 \mathrm{~mm}$ (Table 5). The installations were identical to the ones used during the intensive campaigns whereas data was recorded on a weekly basis but on the same day from all plots.

A useful tool for characterizing and comparing the variation of throughfall are histograms describing the occurrence of measurements in relation to Pg (Hölscher et al. 1998). In the NF stand, the most frequent values were between 40 and 50\%, and shifted with increasing land use intensity to $60-70 \%$ and $70-80 \%$ in the STE and LTE stands, respectively (Fig. 14). In the AF stand, no clear maximum resulted. All distributions differed significantly (two-tailed Wilcoxon test, $p<0.001)$ and were positively skewed. This was most pronounced in the STE and AF stands which showed numerous measurements of $\mathrm{Tf}>200 \%$ of $\mathrm{Pg}$, while such amounts were not recorded in the NF stand at all.

Especially for the most contrasting NF and AF sites, the resulting interception rates $(51 \%$ and $20 \%$ of $\mathrm{Pg}$, respectively) corresponded well with data obtained during the intensive campaigns on the same sites (53\% and 18\% of $P g$, respectively). The interception rates from the STE and LTE sites, however, were considerably higher than during the intensive campaign. Llorens et al. (1997) reported this effect also from the Mediterranean region where shifting temporal scales from daily to weekly observations resulted in a significant increase of measured interception. A possible methodological error, compared to daily measurements, could have arisen from potential evaporation from throughfall collectors if the taken precautions had not been effective. However, all gross rainfall collectors were constructed identically and they were more intensively exposed to insolation which would have consequently resulted rather in an underestimation of interception. An interception of throughfall by debris, which accumulated in the collectors, is also unlikely as this occurred rather equally on all sites, and collectors were cleaned at least once per week. The long term monitoring, temporally integrated precipitation events of various intensities over the period of one week and it is likely that on that scale other processes have contributed to this decrease in measured throughfall and thus increased interception. The intensive campaign had aimed at describing rainfall partitioning on a daily basis. Therefore, only days with measurable

Table 5. Rainfall partitioning in the 4 selected plots from the long-term monitoring.

\begin{tabular}{|c|c|c|c|c|c|c|c|}
\hline & \multirow{2}{*}{$\begin{array}{l}\text { Number of } \\
\text { weeks }\end{array}$} & \multirow{2}{*}{$\begin{array}{l}\text { Gross } \\
\text { precipitation }(\mathrm{mm})\end{array}$} & \multicolumn{3}{|c|}{ Throughfall $^{\mathrm{a}}(\%$ of $\mathrm{Pg})$} & \multirow{2}{*}{$\begin{array}{l}\text { Stemflow } \\
(\% \text { of } P g)\end{array}$} & \multirow{2}{*}{$\begin{array}{l}\text { Interception } \\
(\% \text { of } \mathrm{Pg})\end{array}$} \\
\hline & & & $\overline{25^{\text {th }}}$ & Median & $75^{\text {th }}$ & & \\
\hline NF 1 & 63 & 4360 & 35 & $49^{\mathrm{a}}$ & 62 & 0.6 & 51 \\
\hline STE 2 & 62 & 3985 & 38 & $61^{\mathrm{b}}$ & 78 & 0.7 & 38 \\
\hline LTE 4 & 60 & 3980 & 55 & $71^{\mathrm{c}}$ & 91 & 0.6 & 29 \\
\hline $\mathrm{AF} 3$ & 61 & 3189 & 57 & $79^{\mathrm{d}}$ & 105 & 0.9 & 20 \\
\hline
\end{tabular}

a Shown are the $25^{\text {th }}, 50^{\text {th }}$ (median), and $75^{\text {th }}$ percentiles. Significantly different means between research sites $(\mathrm{n}=30$ rainfall gauges per plot) are indicated by different lower case letters (Wilcoxon signed ranks test, two-tailed, $p<0.05$ ). 
rainfall were considered. Owing to the method of rainfall collection which had a minimum resolution of $0.5 \mathrm{~mm}$, any days with rainfall below $0.8 \mathrm{~mm}$ of $\mathrm{Pg}$ (1.e. minimum resolution $+25 \%$ ) were considered dry and excluded from the analysis. However, such low intensity rains are hardly sufficient to saturate the canopy and thus re-evaporate back into the atmosphere directly from the leaves (Crockford and Richardson 2000, Hall 2003, Manfroi et al. 2006). It is known that in the study area, even the rainfall events $>0.2 \mathrm{~mm}$ have a low average intensity of $3.4 \mathrm{~mm} \mathrm{~h}^{-1}$ (Table 1). During the long-term monitoring, the recording cycle of one week, potentially led to an integration of such effects as $P g$ was allowed to accumulate to substantial and measureable amounts while only a minute fraction of it may have ended up as throughfall. This effect was probably less pronounced where interception was inherently low (e.g. the agroforest) or where already large parts of rainfall were intercepted (e.g. the natural forest) and where additionally rainfall totaled 10\% more than in all other sites. Therefore, the results of the long-term monitoring, although with low temporal resolution, may more accurately describe the throughfall patterns in those stands by also accounting for changes in structure (e.g. branch fall) and rains of low intensity.
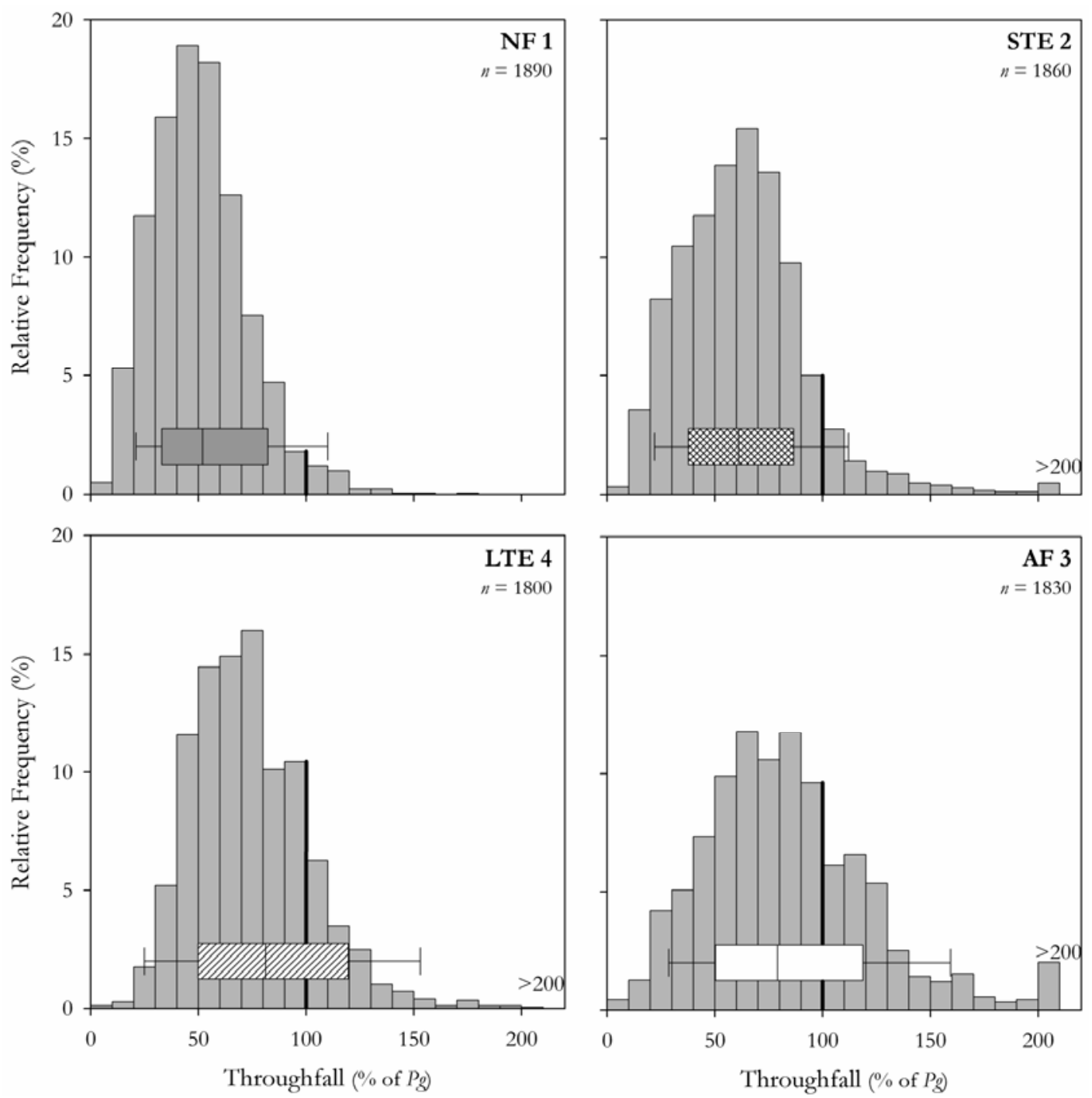

Fig. 14. Histograms of the throughfall distribution on the four investigated long term plots (NF1, STE2, LTE4, AF3) in increments of $10 \%$ of $P g$. Additionally shown are the $5^{\text {th }}, 25^{\text {th }}, 50^{\text {th }}$ (median), $75^{\text {th }}$ and $95^{\text {th }}$ percentiles. 


\subsubsection{Influence of rainfall intensity}

The previously discussed observation that low intensity rainfall may have contributed to substantial differences in throughfall yields on different time scales suggested a more detailed investigation of the effect of rainfall intensity on throughfall and resulting interception patterns. Indeed, e.g. Tobón Marin et al. (2000) showed the dependence of interception on rainfall intensity and duration for the Colombian Amazon and Manfroi et al. (2006) investigated these effects on rainfall partitioning in Borneo.

In this study, rainfall intensities were not directly assessed on a single storm basis but rather based on the integrative weekly data from the long-term observations. Data were divided into four classes of weekly gross precipitation ranging from $\leq 10 \mathrm{~mm}$ of $P g$ to $>150 \mathrm{~mm}$ of $P g$ (Table 6). Most frequently represented were weeks with $P g$ of $10-50$ and $50-150 \mathrm{~mm}$. Lowest throughfall percentages were recorded in the $\mathrm{NF}$ with a $\mathrm{Tf}$ of $46-52 \%$ (median) of $\mathrm{Pg}$. Generally, highest throughfall was recorded in both extreme classes of $\leq 10 \mathrm{~mm}$ and $>150 \mathrm{~mm}$ of $P g$, while the lowest throughfall was recorded in all stands during $10-50 \mathrm{~mm}$ of $P g$. While the effect of increased throughfall under high rainfall conditions is commonly acknowledged (e.g. Crockford and Richardson 2000, Tobón Marin et al. 2000), Manfroi et al. (2006) also point out that after only $5 \mathrm{~mm}$ of rainfall occasionally high throughfall fractions have been observed in Borneo. Most likely, however, is that possibly a limited number of strong storms within the week of observation may have contributed to such high throughfall yields at $\leq 10 \mathrm{~mm}$ of $\mathrm{Pg}$ per week. Seen as a series of land use intensity from lowest in NF to STE, LTE and ultimately AF, the throughfall fractions continuously increased independent of rainfall intensity (Fig. 15).

The variability of throughfall measurements showed a more irregular pattern. The throughfall variability was highest in the NF, STE, and LTE stands under lowest rainfall amounts and

Table 6. Rainfall partitioning on the long-term monitoring 4 plots divided up by different weekly sums of $P g$.

\begin{tabular}{|c|c|c|c|c|c|c|c|c|}
\hline \multirow{2}{*}{\multicolumn{2}{|c|}{$\begin{array}{l}\text { Rainfall intensity } \\
\text { class (mm of } P g \text { ) }\end{array}$}} & \multirow{3}{*}{$\begin{array}{l}\begin{array}{l}\text { Number of } \\
\text { weeks }\end{array} \\
12\end{array}$} & \multirow{3}{*}{$\begin{array}{l}\begin{array}{l}\text { Gross } \\
\text { precipitation }(\mathrm{mm})\end{array} \\
46\end{array}$} & \multicolumn{3}{|c|}{ Throughfall $^{\mathrm{a}}(\%$ of $P g)$} & \multirow{3}{*}{$\begin{array}{l}\begin{array}{l}\text { Stemflow } \\
(\% \text { of } P g)\end{array} \\
0.6\end{array}$} & \multirow{3}{*}{$\begin{array}{l}\begin{array}{l}\text { Interception } \\
(\% \text { of } P g)\end{array} \\
48\end{array}$} \\
\hline & & & & \multirow{2}{*}{$\frac{25^{\text {th }}}{37}$} & \multirow{2}{*}{$\frac{\text { Median }}{52}$} & \multirow{2}{*}{$\frac{75^{\text {th }}}{73}$} & & \\
\hline NF 1 & $\leq 10$ & & & & & & & \\
\hline & $10-50$ & 21 & 611 & 33 & 46 & 59 & 0.6 & 53 \\
\hline & $50-150$ & 18 & 1413 & 34 & 47 & 61 & 0.6 & 53 \\
\hline & $>150$ & 12 & 2291 & 38 & 52 & 65 & 0.6 & 47 \\
\hline \multirow[t]{4}{*}{ STE 2} & $\leq 10$ & 10 & 44 & 41 & 58 & 85 & 0.7 & 41 \\
\hline & $10-50$ & 23 & 672 & 43 & 56 & 71 & 0.7 & 43 \\
\hline & $50-150$ & 21 & 1783 & 33 & 66 & 82 & 0.7 & 33 \\
\hline & $>150$ & 8 & 1485 & 31 & 69 & 81 & 0.7 & 31 \\
\hline \multirow[t]{4}{*}{ LTE 4} & $\leq 10$ & 9 & 36 & 55 & 76 & 96 & 0.6 & 24 \\
\hline & $10-50$ & 24 & 678 & 51 & 68 & 88 & 0.6 & 32 \\
\hline & $50-150$ & 19 & 1847 & 59 & 73 & 91 & 0.6 & 26 \\
\hline & $>150$ & 7 & 1407 & 56 & 70 & 90 & 0.6 & 30 \\
\hline \multirow[t]{4}{*}{ AF 3} & $\leq 10$ & 9 & 28 & 62 & 81 & 100 & 0.9 & 18 \\
\hline & $10-50$ & 28 & 727 & 55 & 77 & 106 & 0.9 & 22 \\
\hline & $50-150$ & 20 & 1745 & 58 & 81 & 108 & 0.9 & 18 \\
\hline & $>150$ & 4 & 688 & 56 & 81 & 104 & 0.9 & 18 \\
\hline
\end{tabular}

a Shown are the $25^{\text {th }}, 50^{\text {th }}$ (median), and $75^{\text {th }}$ percentiles. b identical stemflow proportions result from the application of a rigid model based on regressions of stemflow, basal area distribution and gross precipitation. 
decreased steadily with increasing rainfall in the NF and in STE and LTE stands. Contrastingly, the throughfall variability in the AF stand was lowest under lowest rainfall conditions, albeit consistently higher than in any other forest use type, and maintained a similarly high level under increasing rainfall intensities (Fig. 15 and Fig. 16). The spatial variability of measured throughfall in the AF stand was highest among the studied forest use types.

These results suggest that forests devoid of continuous human management (e.g. NF, STE, and LTE) with a relatively high canopy respond to rains of relatively low intensity with high variation because gaps may play an important role during the process of saturating the canopy. Under such conditions, the variability between precipitation passing freely through existing gaps in the canopy and precipitation retained as interception is highest. This pattern loses its significance once rainfall intensifies and only a small fraction of $P g$ is required to saturate the canopy storage and when increasing canopy drip eventually reduces the contrast between gaps and locations shaded by the canopy (see also Hall 2003). On the other hand, the consistently high
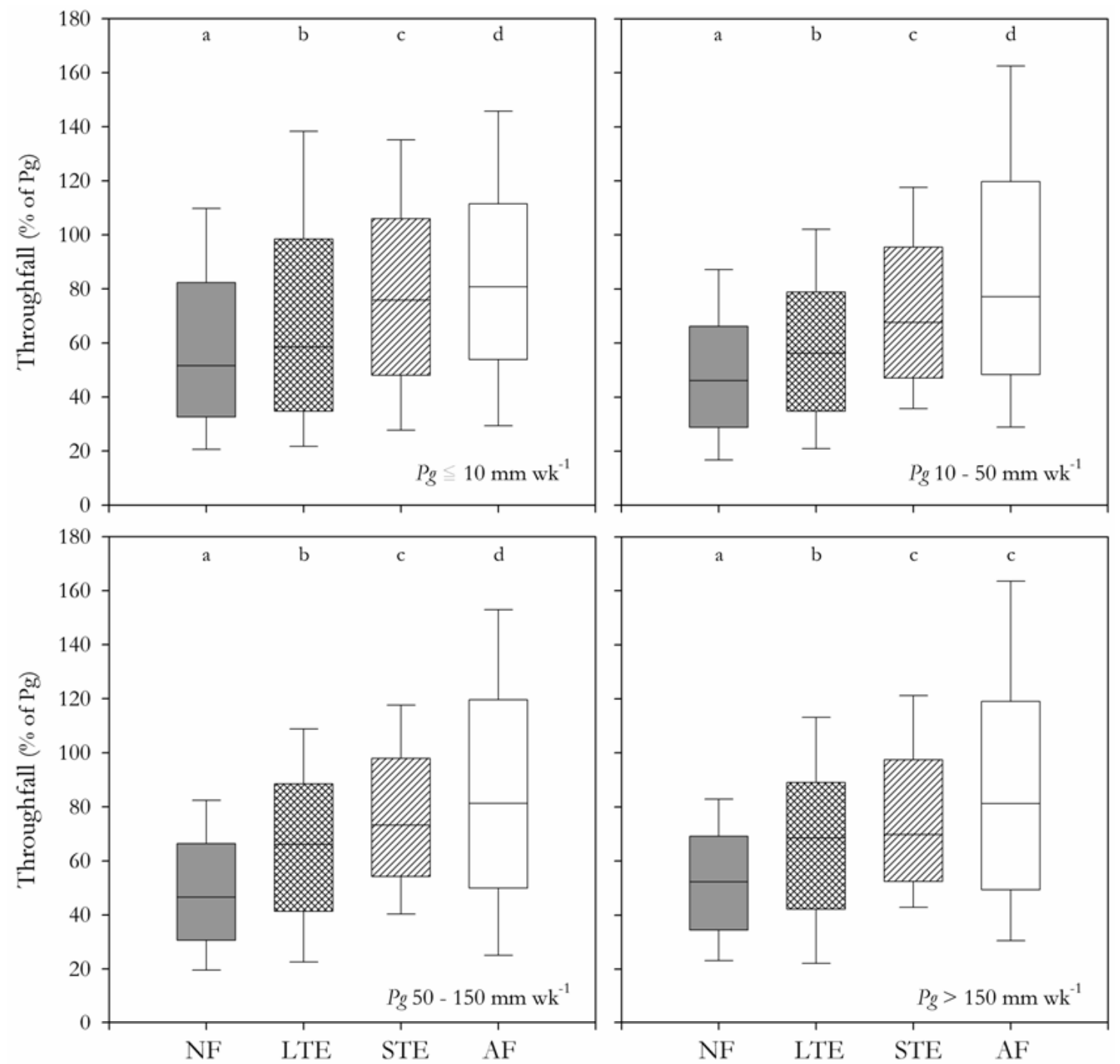

Fig. 15. The variability of throughfall measurements on the four investigated long term plots (NF1, solid; STE2, cross-hatched; LTE4, hatched; AF3, open) in four different classes of weekly Pg. Shown are the $5^{\text {th }}, 25^{\text {th }}, 50^{\text {th }}$ (median), $75^{\text {th }}$ and $95^{\text {th }}$ percentiles. Different means between research sites $(\mathrm{n}=30$ rainfall gauges per plot $)$ are indicated by different lower case letters (Wilcoxon signed ranks test, two-tailed, $p<0.01$ ). 


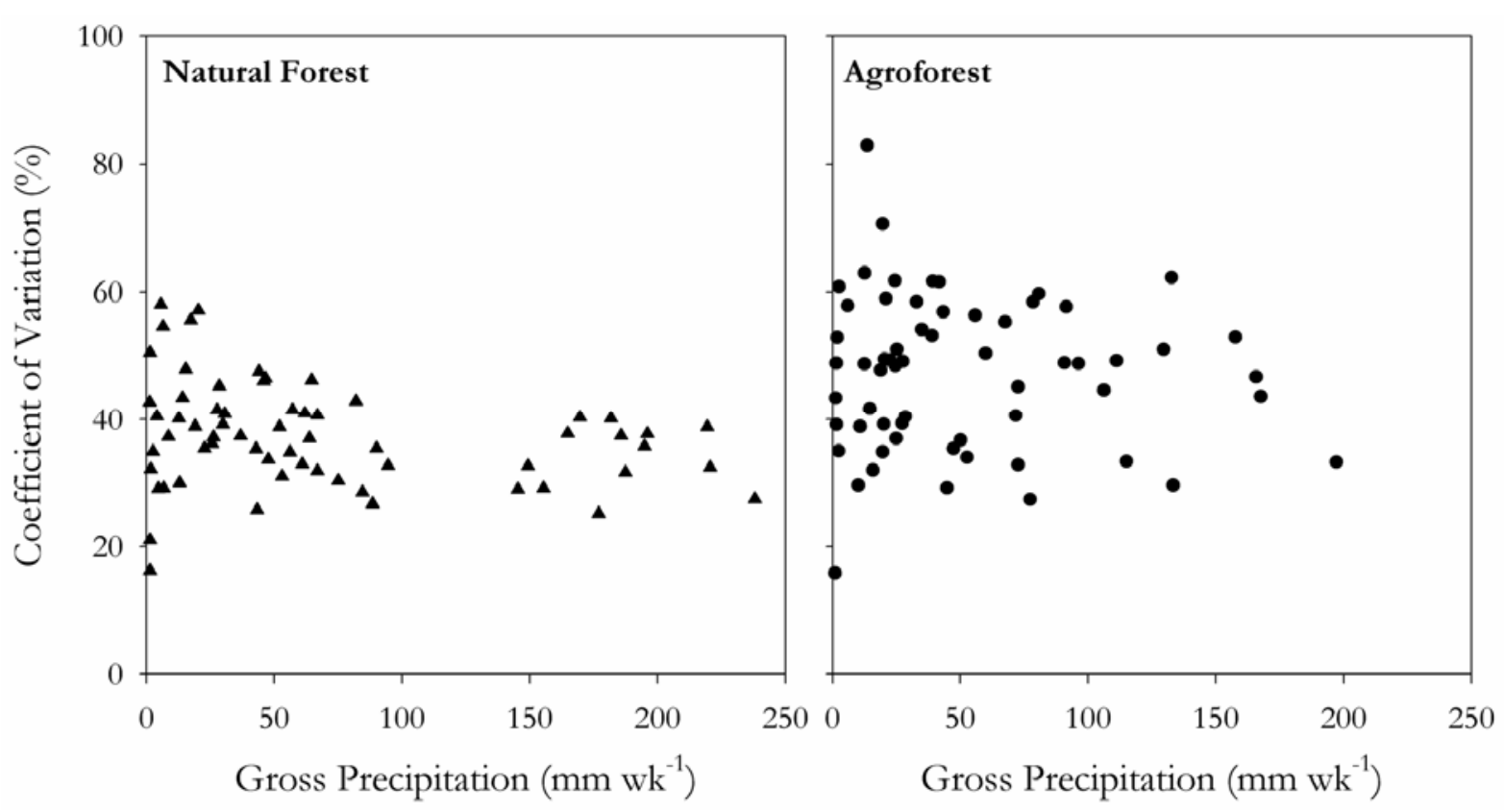

Fig. 16. Relationship between weekly gross precipitation as recorded in the natural forest (left) and in the agroforest (right) and its corresponding coefficient of variation from the throughfall measurements.

variation of throughfall in the AF may be due to the distinct layering of a dense understorey by the cacao trees which are constantly pruned to $\sim 5 \mathrm{~m}$ height (see also chapter 3.2.5 on spatial variability).

Rainfall intensity can also influence the effect that structural properties have on interception (see also chapter 3.2.4). Although correlations obtained with $n=4$ must generally be interpreted with caution, such highly significant correlations as shown in Fig. 17 can demonstrate how interception may respond to different rainfall intensities. Evidently, there is little effect of rainfall intensity on the fraction of interception in NF and AF, while it was highly different between STE and LTE at low rainfall intensity but approached a similar value under highest rainfall intensities (Table 6). In the context of stand structural parameters, the basal area of all trees, which combined information on stand density and dimension of trees, had its highest impact $\left(r^{2}=0.99\right)$ on interception when rainfall was low and the overall canopy storage capacity was a critical parameter. This process appeared to lose its significance under increasing rainfall intensity $\left(r^{2}=0.85\right)$ when canopy storage reached saturation. Inversely, the stem density $(\mathrm{dbh} \geq 50 \mathrm{~cm})$, i.e. the amount of large trees per hectare, correlated best with interception at highest rainfall conditions $\left(r^{2}=1.00\right)$. The density of large diameter trees was shown to respond directly to forest use intensity (Fig. 10) and canopies of large trees are hypothesized to dry up fastest after rainfall which would be of highest importance during periods with high rainfall (see also chapter 3.2.6). 


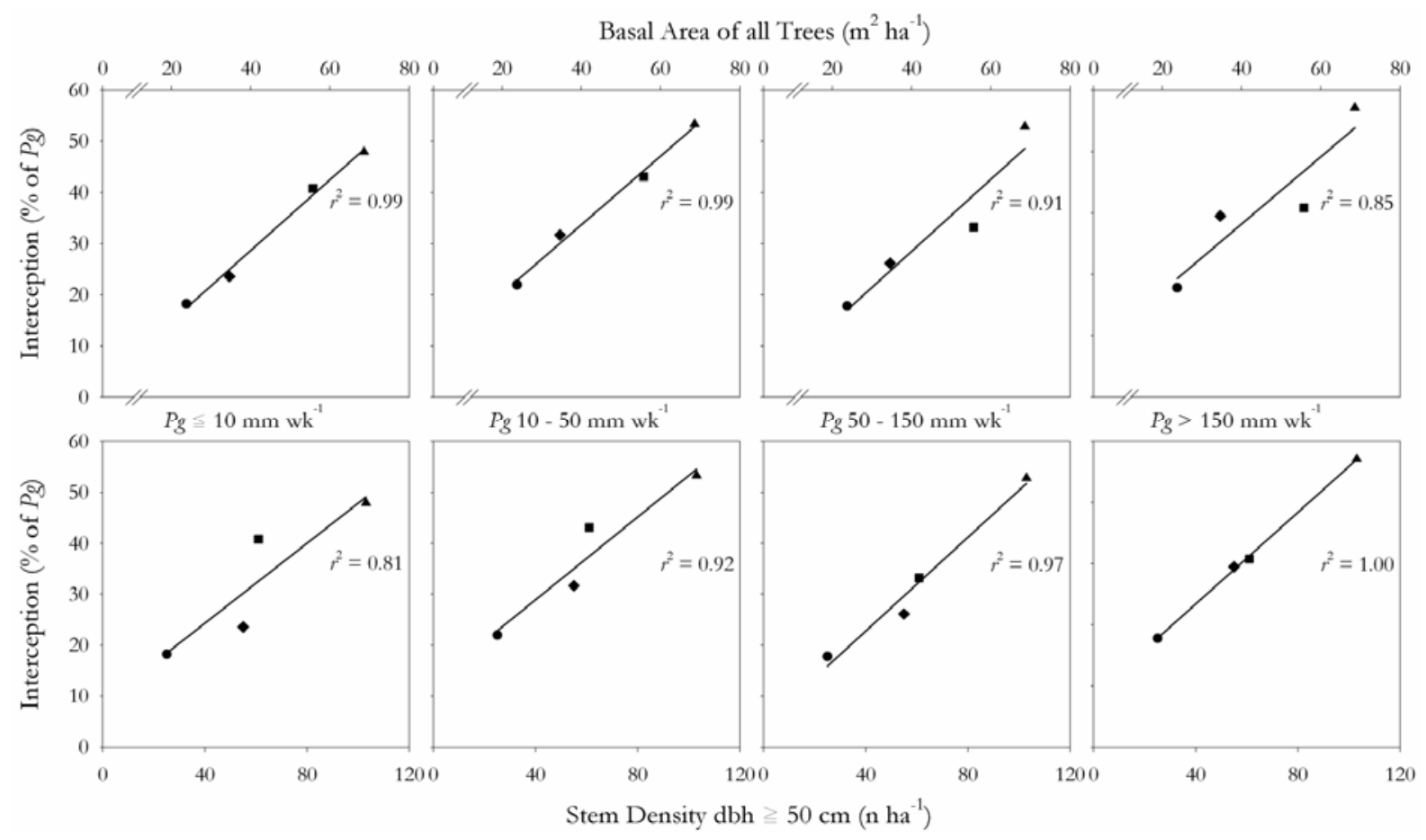

Fig. 17. The relationship of basal area of all trees (above) and mean tree height (below) to interception with

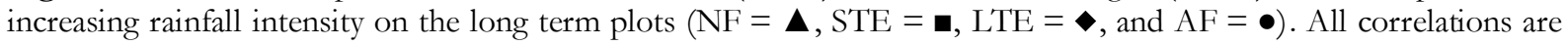
statistically significant (Pearson's correlation, $p<0.05$ ).

\subsubsection{Influence of forest structure}

Hall (2003) had presented a stochastic interception model and already recognized that interception decreases with rainfall intensity but showed that the amount of throughfall was independent from drop sizes of the storm but rather responded to the size of drip that occurred from the canopy itself. This led him to the conclusion that stand structure would have a much larger impact on rainfall partitioning than rainfall intensity by itself. Various studies have investigated differences in rainfall partitioning on different forest types (Hölscher et al. 1998, Tobón Marin et al. 2000) or under contrasting forest use (Asdak et al. 1998, Chappell et al. 2001). Many studies concluded that structural vegetation properties had a significant impact on rainfall partitioning patterns (see Crockford and Richardson 2000). Manfroi et al. (2006) attributed lower throughfall on a permanent plot in Borneo in comparison to surrounding measurements to the presence of a single very large tree. Most prominently, the leaf area was commonly considered a key parameter for interception and its modeling (Gash 1979, van Dijk and Bruijnzeel 2001a). This may be justified e.g. for agricultural crops with quickly expanding leaf area such as studied by van Dijk and Bruijnzeel et al. (2001b) or e.g. in deciduous forests. However, only remarkably few studies are known where more than two sites (e.g. Tobón Marin et al. 2000) were investigated to allow for a screening of correlations between rainfall partitioning and structural characteristics.

All structural parameters of the twelve study plots and the data from the intensive campaigns were used to establish relationships between forest structure and rainfall partitioning. Based on Spearman's rank correlations it became evident that there were no significant correlations 
between topographical parameters and rainfall partitioning for twelve study plots (Table 7). The mean dbh of stems $\mathrm{dbh} \geq 10 \mathrm{~cm}$ correlated significantly with the throughfall percentage (Spearman's rho $=-0.69)$. The correlation consolidated when only days of strong precipitation ( $\geq 10 \mathrm{~mm}$ of $P g$ ) were considered (see also Fig. 17). Strong correlations were obtained between throughfall and all parameters of tree height. The throughfall percentage increased significantly with decreasing tree height. Mean tree height $(\mathrm{dbh} \geq 10 \mathrm{~cm})$ yielded a Spearman's rho of -0.74 and stand mid height of -0.71 . The strongest correlation was observed between the lower crown limit (lowest point of ramification) and throughfall (Spearman's rho $=-0.83$ ). As stemflow did not differ much among the study plots, the results on throughfall almost directly applied inversely to interception, which was thus equally correlated to tree height (Table 7). On the twelve study plots, LAI and canopy openness alone were not significantly correlated with interception. However, a multiple linear regression with mean tree height $(\geq 10 \mathrm{~cm}$ dbh) and LAI as parameters explained $81 \%$ of the variation observed in interception which substantially improved the regression of mean tree height with interception $\left(r^{2}=0.63\right.$; Fig. 18).

An explanation why LAI was not a main determinant of rainfall partitioning in this study, but why rather stem density and especially tree height correlated closest with throughfall could be that the potential canopy water storage, to which leaf area contributes significantly, is not available at every rainfall event. For the natural forest stand in Bariri was shown, that during rainy periods the canopy surfaces remained wet for more than $50 \%$ of the time (see chapter 3.2.6). Thus, besides the size of the canopy water storage, its actual availability, which may be controlled

Table 7. Spearman's rank correlation coefficients (two-tailed) between rainfall partitioning components and stand structural characteristics for the 12 study plots.

\begin{tabular}{|c|c|c|c|c|}
\hline & \multicolumn{3}{|c|}{ Throughfall $(\%$ of $P g)$} & \multirow{2}{*}{$\begin{array}{l}\text { Interception }(\% \text { of } P g) \\
\text { All days }\end{array}$} \\
\hline & $\overline{P g} \leq 10 \mathrm{~mm} \mathrm{~d}^{-1}$ & $P g>10 \mathrm{~mm} \mathrm{~d}^{-1}$ & All days & \\
\hline Elevation ( $\mathrm{m}$ asl) & -0.02 & 0.40 & 0.32 & -0.32 \\
\hline Exposition $\left({ }^{\circ}\right)$ & -0.13 & -0.13 & -0.03 & 0.03 \\
\hline Inclination $\left(^{\circ}\right)$ & 0.19 & -0.50 & -0.36 & 0.36 \\
\hline \multicolumn{5}{|l|}{ Stem density } \\
\hline all stems $\left(\mathrm{n} \mathrm{ha}^{-1}\right)$ & 0.13 & 0.24 & 0.16 & -0.16 \\
\hline $\mathrm{dbh} \geq 10 \mathrm{~cm}\left(\mathrm{n} \mathrm{ha}^{-1}\right)$ & -0.12 & 0.23 & 0.09 & -0.09 \\
\hline $\mathrm{dbh} \geq 50 \mathrm{~cm}\left(\mathrm{n} \mathrm{ha}^{-1}\right)$ & -0.39 & -0.31 & -0.39 & 0.39 \\
\hline \multicolumn{5}{|l|}{ Basal area } \\
\hline all stems $\left(\mathrm{m}^{2} \mathrm{ha}^{-1}\right)$ & -0.42 & -0.45 & -0.52 & 0.52 \\
\hline $\mathrm{dbh} \geq 10 \mathrm{~cm}\left(\mathrm{~m}^{2} \mathrm{ha}^{-1}\right)$ & -0.56 & -0.28 & -0.41 & 0.41 \\
\hline Mean dbh $(\mathrm{dbh} \geq 10 \mathrm{~cm})(\mathrm{cm})$ & -0.36 & $-0.83 * * *$ & $-0.69 *$ & $0.60 *$ \\
\hline Mean tree height $(\mathrm{dbh} \geq 10 \mathrm{~cm})(\mathrm{m})$ & $-0.58 *$ & $-0.76 * *$ & $-0.74 * *$ & $0.74 *$ \\
\hline Stand mid height (mean dbh) (m) & $-0.58 *$ & $-0.69 *$ & $-0.71 * *$ & $0.71 *$ \\
\hline Stand top height (highest $10 \%$ ) (m) & $-0.69 *$ & -0.52 & -0.51 & 0.51 \\
\hline Crown extension (m) & -0.32 & $-0.73 * *$ & $-0.61 *$ & $0.61 *$ \\
\hline Low crown limit (m) & $-0.71 *$ & $-0.78 * *$ & $-0.83 * * *$ & $0.83 * * *$ \\
\hline Leaf area index $\left(\mathrm{m}^{2} \mathrm{~m}^{-2}\right)$ & -0.15 & 0.09 & 0.14 & -0.14 \\
\hline Canopy openness (\%) & -0.01 & 0.13 & 0.29 & -0.29 \\
\hline
\end{tabular}

Significant correlations $(p<0.05)$ are highlighted in bold. $\left({ }^{*} p<0.05,{ }^{* *} p<0.01,{ }^{* * *} p<0.001\right)$ 
by evaporation processes, is important as well. Taller trees are commonly associated with a greater roughness length of the stand which therefore receives a more effective turbulent energy exchange with the atmosphere (e.g. Kelliher et al. 1993). As a consequence, the canopy would dry up more often between rainfall events in tall stands and would remain wet for longer periods of time in stands with lower-statured trees and a more clumped distribution of the foliage. A result pointing in the same direction was found in a montane forest of Costa Rica, where young secondary and old-growth forests differed greatly in rainfall interception but not in LAI, and the higher epiphyte abundance in the old-growth stand could not explain the observed differences (Hölscher et al. 2004, Köhler et al. 2006). The authors similarly suggested that a more effective energy exchange in the taller old-growth forest might have caused these patterns. The canopy roughness may also be of great importance for differences in rainfall interception between logged and unlogged forest (Asdak et al. 1998, Chappell et al. 2001). In Central Kalimantan, Asdak et al. (1998) found that logging reduced the rainfall interception and discussed the reduced roughness of logged stands as a probable cause. On the other hand, Chappell et al. (2001) found an increase in interception after logging and suggested that a higher roughness length may increase the energy exchange with the atmosphere leading to higher evaporation rates, while tall trees would also enhance the capture of falling rain drops from turbulent eddies and thus experience a higher precipitation than smaller trees. However, in our study region in Sulawesi, the effect of canopy roughness on evaporation (cf. Asdak et al. 1998) seemed to prevail over any positive effect by large trees on precipitation (cf. Chappell et al. 2001). Thus, our results support the view by Asdak et al. (1998) that logging reduces the tree height, which may affect surface roughness, and consequently reduces the rainfall interception in altered tropical moist forests.

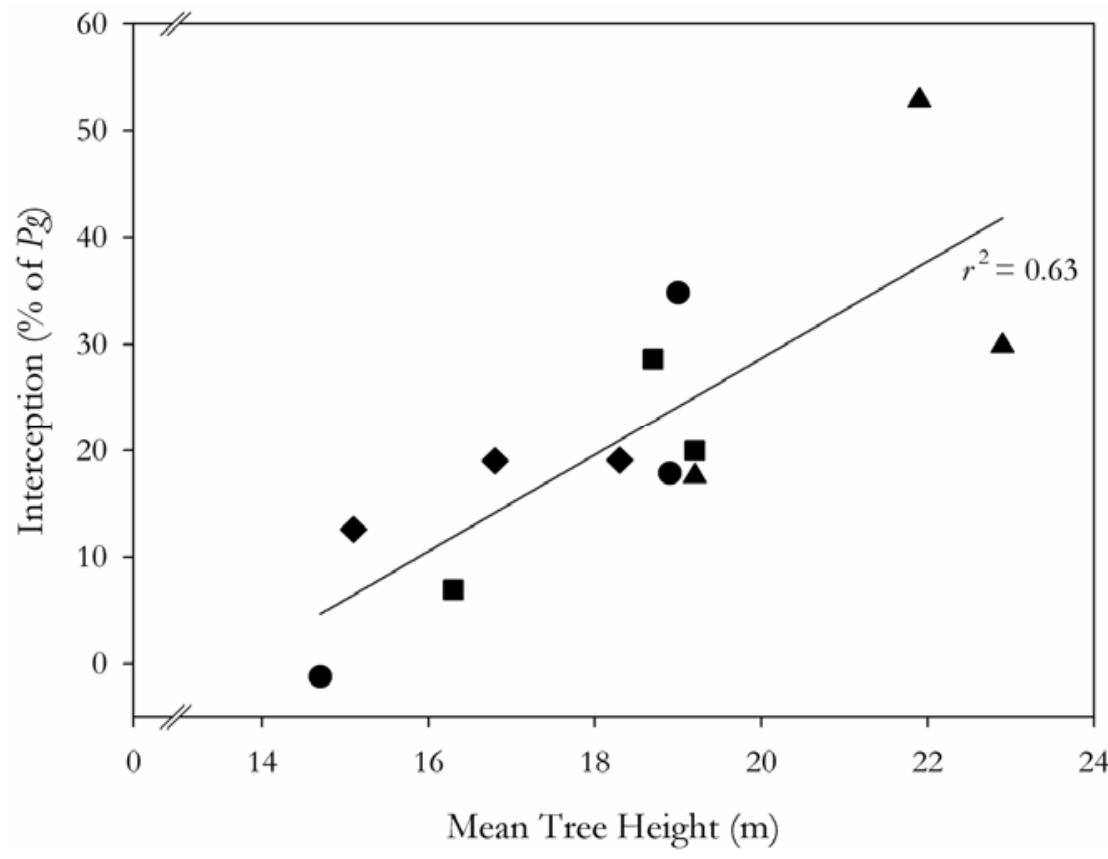

Fig. 18. Rainfall interception as a function of mean tree height $(\mathrm{dbh} \geq 10 \mathrm{~cm})$ in the 12 study plots $(\mathrm{NF}=\boldsymbol{\Delta}$, $\mathrm{STE}=\mathbf{\square}, \quad \mathrm{LTE}=\bullet, \quad$ and $\mathrm{AF}=\bullet$ ). 


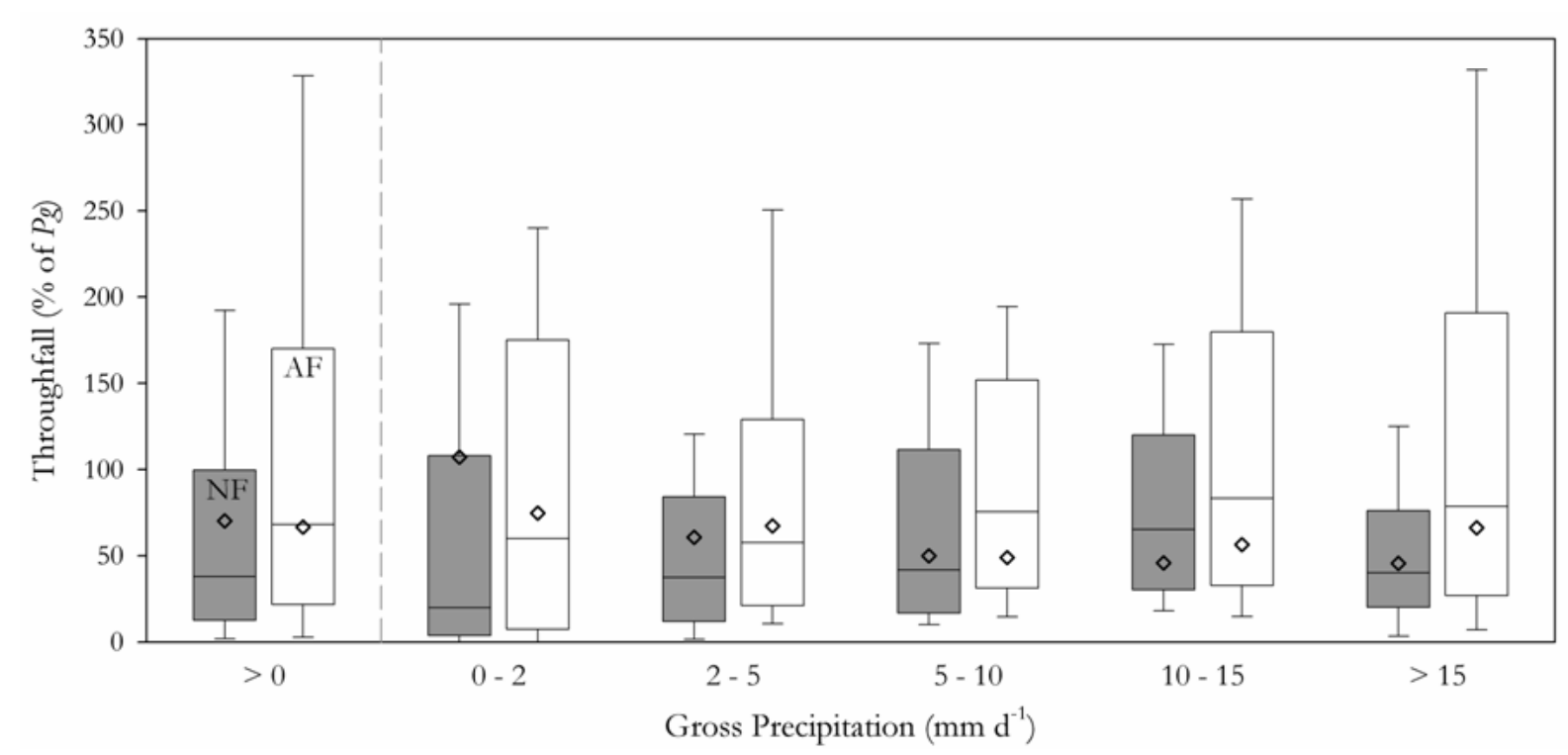

Fig. 19. The variability of throughfall measurements using the roving gauge technique in a natural forest (NF, solid) and an agroforest (AF, open) and the coefficient of variation $(\diamond)$.Shown are the $5^{\text {th }}, 25^{\text {th }}, 50^{\text {th }}$ (median), $75^{\text {th }}$ and $95^{\text {th }}$ percentiles.

\subsubsection{Spatial variability}

A $3 \times 3 \mathrm{~m}$ grid was laid out on one natural forest (NF1) and one agroforest (AF4) plot resulting in 176 grid points per plot. Leaf area and canopy openness were determined at each grid point through hemispherical photography and the position of all trees $>2 \mathrm{~m}$ in height was recorded. On 26 days of rain, throughfall was measured with 30 collectors per plot using the roving gauge technique (i.e. after 3 days of rain the $T f$ collectors were moved to another randomly selected set of grid points). This technique has been suggested to account best for spatial heterogeneity of throughfall as it increases the probability of including drip points (Lloyd and Marques 1988, Holwerda et al. 2006, Manfroi et al. 2006).
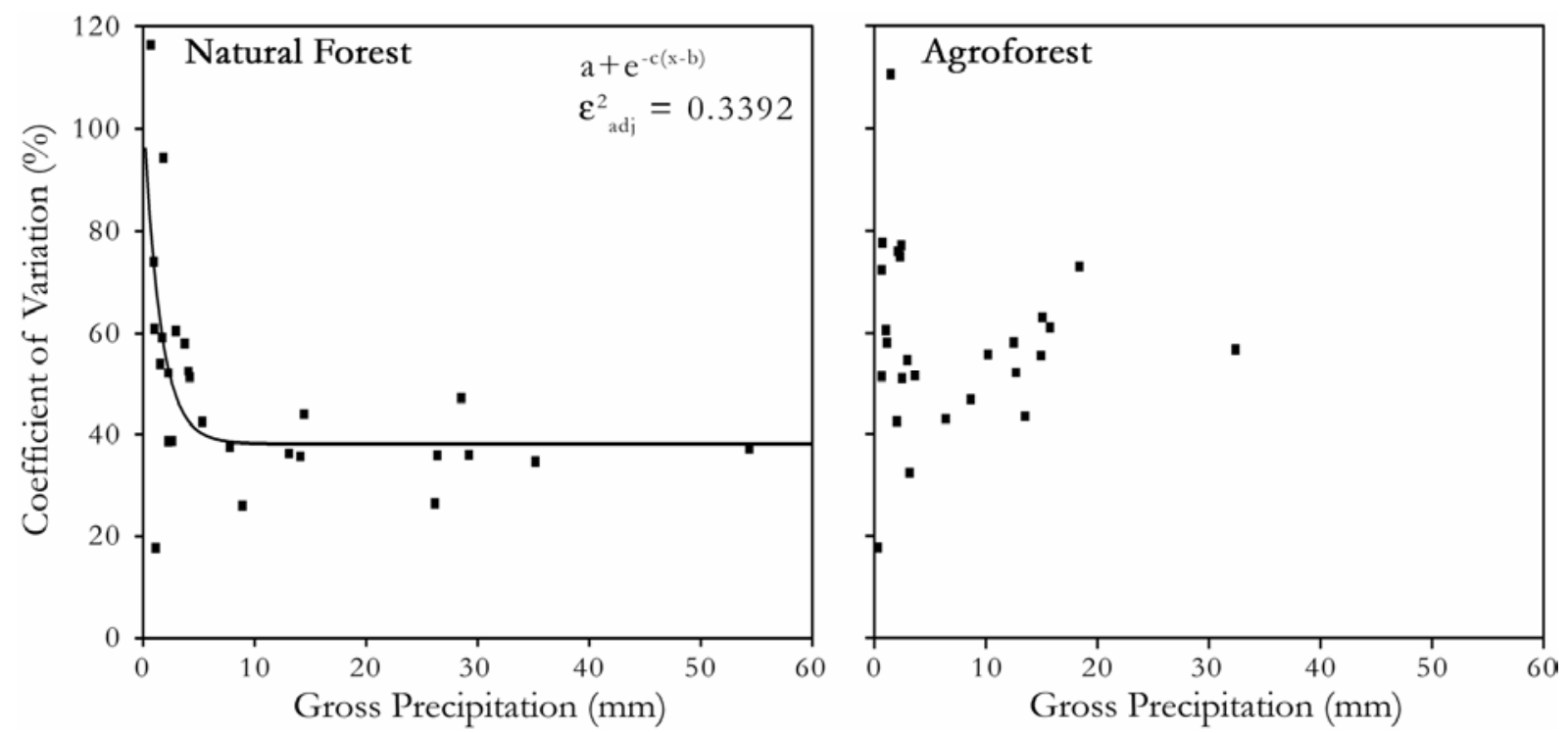

Fig. 20. Relationship between gross precipitation as recorded in the natural forest (left) and in the agroforest (right) and its corresponding coefficient of variation from the grid based throughfall measurements. 
Indeed, highest values of throughfall exceeded both in the natural forest (maximum $212 \%$ ) and in the agroforest (maximum 365\%) the highest measurements recorded in these forests during the intensive campaign and the long-term monitoring with fixed gauges $137 \%$ in the NF and $340 \%$ in the AF). In the natural forest, $0.3 \%$ of all measurements exceeded $200 \%$ of $P g$, while in the agroforest this occurred in $4.5 \%$ of all measurements. When classifying the rainfall into five categories (Fig. 19), the dependence of throughfall variability from rainfall intensity was confirmed as discussed earlier in chapter 3.2.3. Analog to Fig. 16, the gross precipitation of all 26 days of rainfall were plotted against the coefficient of variation from the corresponding throughfall measurements (Fig. 20). In the natural forest, the coefficient of variation (cv) of throughfall was $105 \%$ for rainfall events of $P g<2 \mathrm{~mm}$, but stabilized at a $c v$ of $\sim 40 \%$ once $P g$ exceeded $5 \mathrm{~mm}$. In the agroforest, the $c v$ exceeded the natural forest at $P g>5 \mathrm{~mm}$ and tended to increase with increasing rainfall intensity.

Decreases in spatial variability of throughfall with increasing volume of rainfall have previously been reported from broad-leaved and coniferous forests of the temperate, Mediterranean and sub-tropical zones (Aussenac 1970, Kimmins 1973, Presslan 1973, Loustau et al. 1992, Llorens et al. 1997, Carlyle-Moses et al. 2004). The very high throughfall variation in the natural forest at low rainfall $(0-2 \mathrm{~mm})$ can be explained by the fact that such rainfall amounts are not sufficient for saturating the water storage capacity of the canopy in the whole stand, thus resulting in canopy patches where leaf drip occurs and others where all water is retained. In the agroforest stand, it appears that a more homogenous lower canopy formed by the large cacao leaves allow for a more homogenous throughfall generation at low rainfall intensities. In contrast, at higher storm intensities $(>10 \mathrm{~mm})$, the agroforest stand showed a greater spatial heterogeneity of throughfall than the natural forests. It is likely that this is caused by the patchy upper canopy together with the contiguous layer of cacao trees which intercept drip from the upper canopies and effectively channel this water to consistent local drip points. This explanation is supported by the study of Hall (2003) on the effects of raindrop size who concluded that instead of the raindrop size of the actual rainstorm, the characteristics of the canopy drip largely determined throughfall patterns. It is therefore comprehensible that in higher statured natural forest drip falling from large heights is less likely to consistently reach a clearly defined spot on the forest floor. Spatial patterns of the drip from a low canopy $(<5 \mathrm{~m})$, however, may be more consistent as less scattering of droplets may occur.

Table 8. Mantel's correlation coefficients $(r)$ from testing selected variables for spatial autocorrelation.

\begin{tabular}{|c|c|c|c|c|c|}
\hline & & \multicolumn{2}{|c|}{ Natural Forest } & \multicolumn{2}{|c|}{ Agroforest } \\
\hline & & $r$ & $p$ & $r$ & $p$ \\
\hline \multicolumn{2}{|c|}{ Canopy openness } & 0.04 & 0.101 & 0.15 & $<0.001$ \\
\hline \multicolumn{2}{|l|}{ LAI } & 0.03 & 0.167 & 0.01 & 0.394 \\
\hline \multirow[t]{3}{*}{ Tf } & $P g>0 \mathrm{~mm}$ & 0.03 & 0.167 & 0.02 & 0.305 \\
\hline & $P g 0-5 \mathrm{~mm}$ & 0.03 & 0.219 & 0.12 & 0.009 \\
\hline & $P g \geq 5 \mathrm{~mm}$ & 0.01 & 0.402 & -0.03 & 0.783 \\
\hline \multirow[t]{3}{*}{ Trees } & $\geq 2 \mathrm{~m}$ & n.d. & n.d. & 0.04 & 0.091 \\
\hline & $\mathrm{dbh}<10 \mathrm{~cm}$ & n.d. & n.d. & 0.02 & 0.246 \\
\hline & $\mathrm{dbh} \geq 10 \mathrm{~cm}$ & 0.08 & 0.016 & 0.07 & 0.020 \\
\hline
\end{tabular}

Significant correlations $(p<0.05)$ are highlighted in bold. 
Table 9. Correlation coefficients ( $r$ ) from the partial Mantel test on selected variables form the natural and agroforest.

\begin{tabular}{|c|c|c|c|c|c|c|c|}
\hline & & \multicolumn{3}{|c|}{ Throughfall in natural forest } & \multicolumn{3}{|c|}{ Throughfall in agroforest } \\
\hline & & $\overline{P g}>0 \mathrm{~mm}$ & $P g 0-5 \mathrm{~mm}$ & $P g \geq 5 \mathrm{~mm}$ & $\overline{P g}>0 \mathrm{~mm}$ & $P g 0-5 \mathrm{~mm}$ & $P g \geq 5 \mathrm{~mm}$ \\
\hline \multirow{5}{*}{$\begin{array}{l}\text { Canop } \\
\text { LAI } \\
\text { Trees }\end{array}$} & Openness & 0.01 & -0.02 & 0.03 & 0.03 & 0.10 & 0.03 \\
\hline & & 0.11 & 0.08 & 0.10 & 0.09 & 0.05 & 0.05 \\
\hline & $\geq 2 \mathrm{~m}$ & n.d. & n.d. & n.d. & 0.00 & -0.02 & -0.01 \\
\hline & $\mathrm{dbh}<10 \mathrm{~cm}$ & n.d. & n.d. & n.d. & 0.00 & 0.00 & 0.02 \\
\hline & $\mathrm{dbh} \geq 10 \mathrm{~cm}$ & -0.07 & -0.08 & 0.02 & -0.02 & -0.05 & -0.03 \\
\hline
\end{tabular}

Significant correlations $(p<0.05)$ are highlighted in bold.

The grid based setup of this experiment in the natural forest and agroforest stand allowed for the spatial assessment of throughfall patterns and structural parameters such as LAI, canopy openness and the spatial arrangement of trees. Analyzing the data for spatial autocorrelation using the simple Mantel test revealed that the distribution of trees $\mathrm{dbh} \geq 10 \mathrm{~cm}$ was spatially autocorrelated, i.e. not randomly distributed, in both the natural forest and the agroforest stand (Table 8). Additionally, the differences in canopy openness and the pattern of throughfall at $\mathrm{Pg}$ $0-5 \mathrm{~mm}$ showed significant autocorrelation in the agroforest. Results from the partial Mantel test, which compares variables recorded on the same locations with correcting for effects of spatial distances, showed significant correlations in the natural forest between LAI and throughfall which is most pronounced at high rainfall intensities (Table 9). This suggests that under high rainfall conditions the spatial distribution of the leaf area has a significant effect on the differences in throughfall which are encountered. In the agroforest, on the other hand, the significantly autocorrelated patterns of canopy openness and throughfall from low intensity rains matched significantly. This relationship indicates, that especially during light rains the canopy gap patterns are reflected by the differences in measured throughfall. Keim et al. (2005) concluded from their study in a coniferous stand in the Pacific Northwest of the USA that spatial patterns of throughfall can be reproduced at the same stand over time but were not predictable from tree locations. The results from our study confirmed that spatial variability exists but that it is most likely caused by a combination of forest structure and rainfall intensity and thus spatial variability of throughfall remains highly specific to structural and climatic conditions of each site.

\subsubsection{Leaf surface wetness}

Besides linking atmospheric and plant processes, the vegetation and particularly the forest canopy plays an important role as interface between atmospheric and terrestrial water fluxes by intercepting and storing precipitated water on its foliage, branches and epiphytic components (e.g. Herwitz 1985, Bruijnzeel and Proctor 1997, Hölscher et al. 1998, 2004). So far, many interception models have resorted to the simplified assumption that the canopy would dry up completely between subsequent rainfall events (Gash 1979, van Dijk and Bruijnzeel 2001a). Simultaneously, the authors acknowledged that such postulation helps with the simplification of the model while it may not comply with realistic processes and thus restrict the effective 
application of the model to certain climatic conditions (see also Lloyd and Marques 1988, Dykes 1997). Llorens et al. (1997) concluded that leaf surface wetness is an important factor for interception, mostly due to its role of governing the available part of the canopy storage. However, leaf wetness conditions are often not appropriately addressed in many studies of rainfall partitioning due to the methodological challenges of its assessment.

In this study, leaf wetness was measured using 30 automatic sensors along a vertical profile within the forest canopy between 1.5 and $33 \mathrm{~m}$ at $1.5 \mathrm{~m}$ intervals. Two scenarios of typical days for the study site in Bariri were recorded in three heights on a bright cloudless day on June 22, 2004 and on June 11, 2004 when a single strong afternoon thunderstorm provided precipitation for one hour followed by another short storm $\sim 3$ hours later (Fig. 21). It was demonstrated that in the early morning hours of the dry June 22, only the upper canopy surface cooled off completely to allow dew formation on its leaves which lasted until $\sim 1$ hour after sunrise. Contrastingly, on June 11, the leaves had been continuously wet for the entire night but the upper canopy dried off within $\sim 2$ hours after sunrise while the understorey remained wet more than 5 hours longer. The effects of a small drizzle of $0.2 \mathrm{~mm}$ were confined to the upper canopy but led to a leaf wetness of more than 1 hour, while the less affected lower regions dried off much quicker. Two hours after the understorey had dried off, rainfall started and left the canopy wet until the next storm hit $\sim 2$ hours later. It can be assumed, that for the second rainfall event on that day only a fraction of the canopy water storage was available for interception.

Different durations of leaf wetness were also found over longer study periods. Letts and Mulligan (2005) who measured leaf wetness in the tropical montane cloud forest of Colombia measured up to a height of $10 \mathrm{~m}$, where the leaves were wet for $10-20 \%$ of the time, while a down facing sensor at $2.5 \mathrm{~m}$ recorded wetness for $40-70 \%$ of the time with strong diurnal oscillations. The canopy in Bariri was wet during an average of $25-30 \%$ of time during a three-month observation period (Fig. 22). However, comparing extreme two-week scenarios within that period, surface wetness lasted still for $5 \%$ of the time in a relatively dry period, whereas the canopy was wet during 45 to $55 \%$ of the time in a rainy period. The profiles of leaf wetness duration show peaks at heights of 7.5, 14.5 and $21 \mathrm{~m}$ which are more pronounced, i.e. leaf wetness lasted longer, under higher rainfall. Particularly interesting was the leaf wetness under different rainfall conditions in the uppermost canopy. Under dry conditions, the formation of dew in the mornings contributed to substantially longer leaf wetness of the leaves at $28.5 \mathrm{~m}$

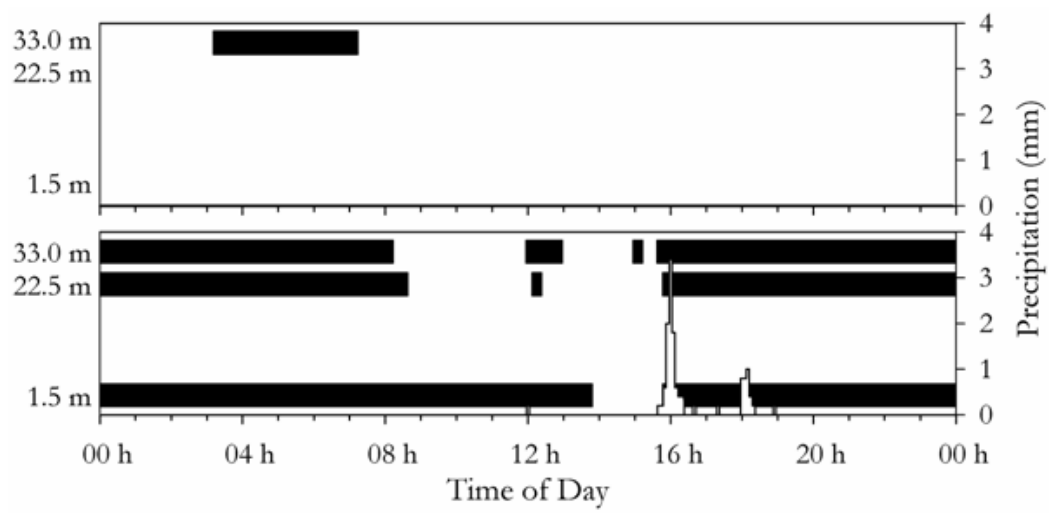

Fig. 21. Duration of surface wetness at 1.5, 22.5 and $33.0 \mathrm{~m}$ height inside the forest on June 22 (above) and June 11(below). 
than anywhere else in the profile below. Under low rainfall conditions, the increase of leaf wetness duration from 27 to $28.5 \mathrm{~m}$ was also observed, although the upper canopy region tended to be drier than the profile below which lends support to the assumption that upper canopy regions of tall trees dry off faster than foliage in lower canopy strata. The phenomenon that shortest leaf wetness under high rainfall conditions was recorded at $24 \mathrm{~m}$ suggests that this lower foliage region of the investigated tree could be a transition zone where (i) still rapid drying takes places induced by higher turbulent atmospheric exchange in comparison to lower canopy zones and (ii) rains of lower intensity may not reach to saturate the leaves. Integrating those effects over time, these patterns are increasingly blurred which confirms that the knowledge of prevailing rainfall conditions is essential for exact predictions of leaf wetness and interception as suggested in the modeling approach by Rutter et al. (1971).

The leaf area index was measured using hemispherical photography along the same vertical profile as the sensors were placed. Although effects of large branches, which concentrate above $\sim 24 \mathrm{~m}$, on such optical methods must be considered, the LAI decreased linearly with tree height (Fig. 23). Interestingly, some anomalies coincided with peaks in the leaf wetness duration which is a further indication that clumping of leaves may have a positive effect on leaf wetness duration and that therefore a more even vertical distribution of leaf area would favor more rapid drying of the foliage.

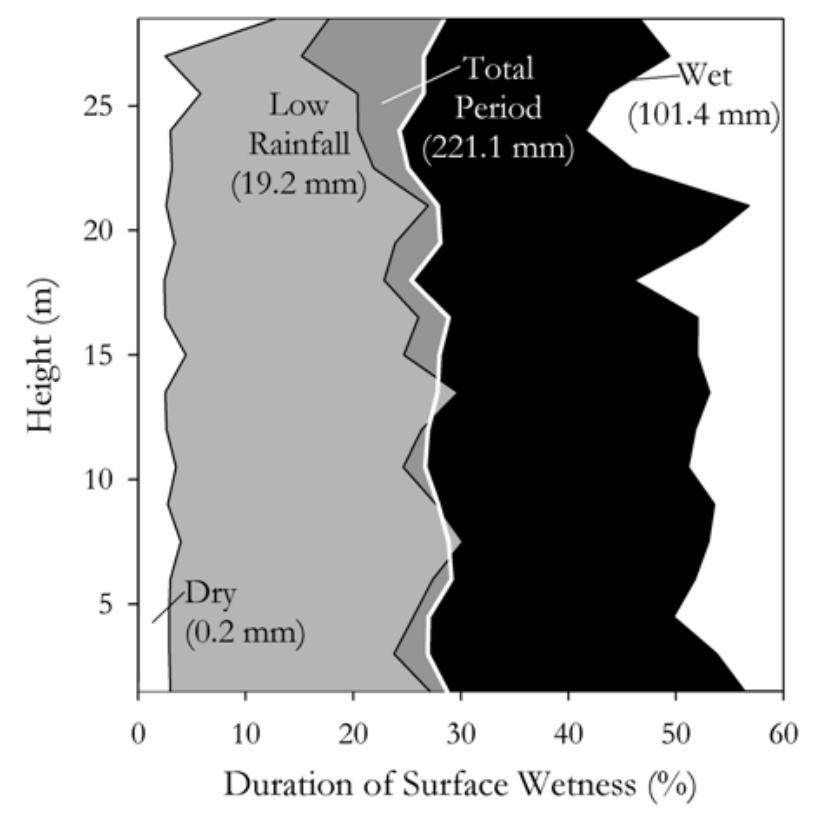

Fig. 22. Duration of surface wetness as percentage of a two-week observation period each. Shown are a leaf wetness profiles for a dry period (white), a period of low rainfall (shaded), and a wet period (black). The while line delimits the observed profile as integrated over a 3-month period.

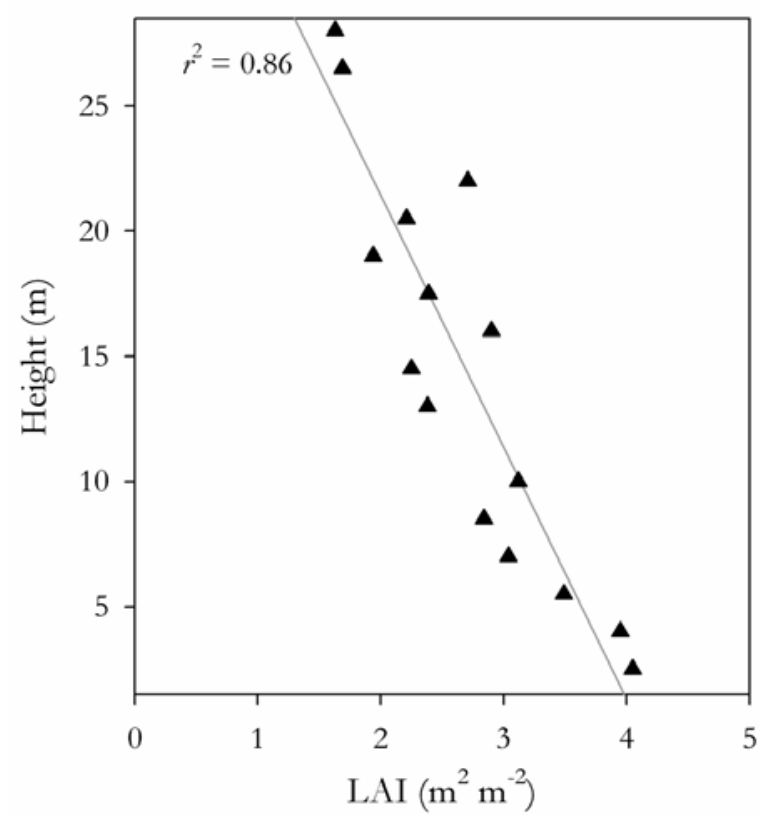

Fig. 23. Leaf area index as estimated from hemispherical photos along a vertical profile in the natural forest in Bariri. 


\section{Outlook}

The correlation between measured interception and structural parameters, particularly mean tree height, was an encouraging result. As demonstrated, the data suggested that mean tree height was a suitable proxy for underlying properties and processes. Perhaps it would describe the structural heterogeneity of the upper canopy which may be indicative for the surface roughness of a stand and thus has an influence on the degree of turbulent energy exchange of the stand with the atmosphere.

Within the cooperation of the STORMA project, a working group of mathematicians, remote sensing specialists, and forest ecologists was able to calibrate measured interception data from the 12 study sites against canopy structure (local maxima) as obtained from a high resolution satellite image. In combination with vegetation indices a regional interception model has evolved which comprises a spectrum of realistic interception values (Fig. 24) where values above 30\% of interception are scarce. Nonetheless, the high measured interception values were valuable for model calibration. A 784 ha area of forest surrounding Toro was divided into 5224 grid cells of $1500 \mathrm{~m}^{2}$ each (Fig. 25). The distribution of

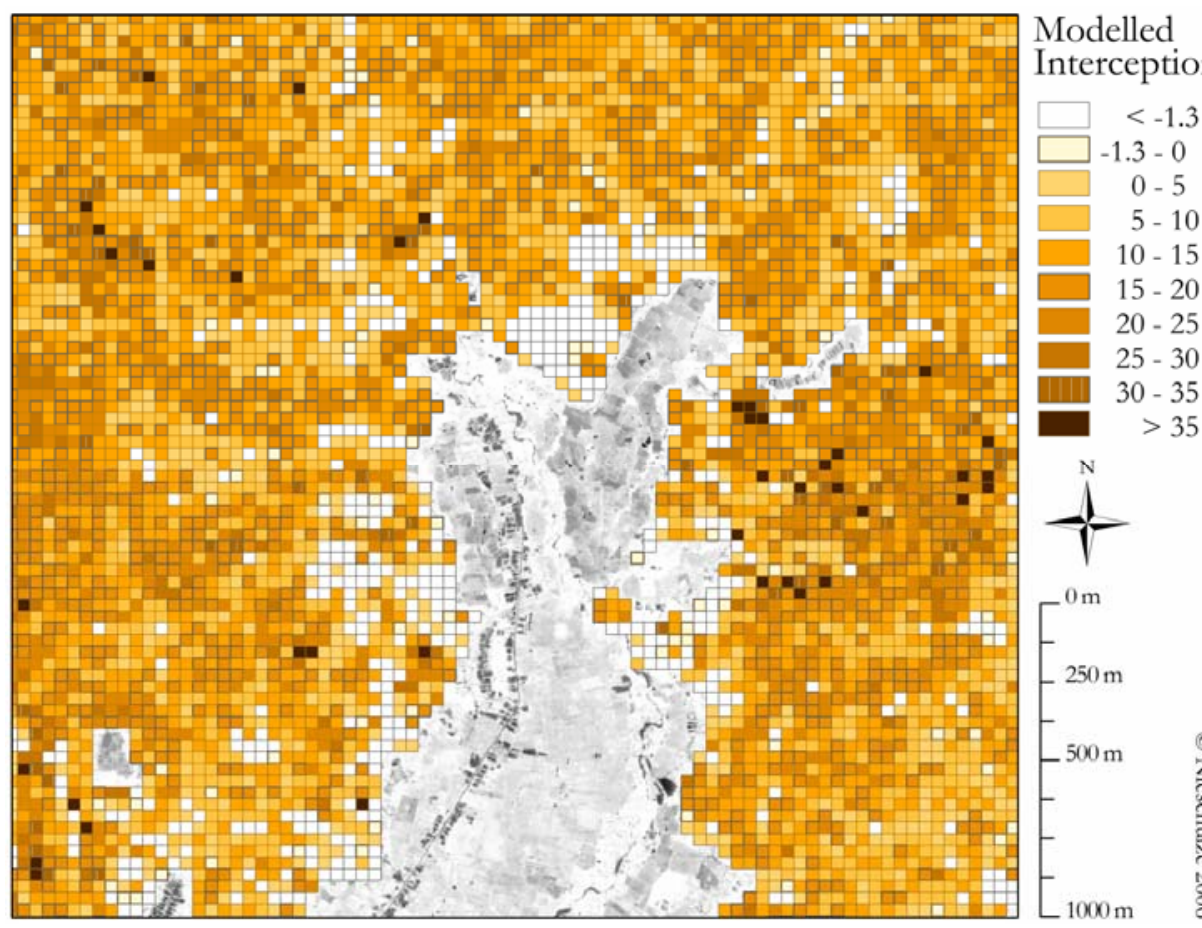

Fig. 25. Modelled interception for 783.6 ha of (2) forest on the slopes surrounding the Toro valley.

Source: Nieschulze et al. §ू (in prep.) 
predicted interception reflects well the anticipated patterns with rare peaks of interception just below ridges and lowest interception towards the lower hill slopes which are traditionally subject to highly intensive forest management as cacao agroforests. The modeled median of interception from the 5224 grid cells was $13 \%$ of gross precipitation. These results serve as further evidence that the heterogeneity of the forest canopy (local maxima) combined with leaf area (vegetation index) are reliable proxies for interception loss (Dietz et al. 2007) and that a regionalization of rainfall partitioning patterns is viable based upon these assumptions. 


\section{Conclusions}

In conclusion, this study has demonstrated that:

(i) Different traditional forest use in the margin zone of the Lore Lindu National Park changed the stand structural characteristics considerably. Strong effects on stem density, basal area and stand height were found, whereas the leaf area index seemed to be less affected.

(ii) Human forest use, particularly the formation of cacao agroforests, led to an increase in throughfall and its spatial variability.

(iii) The partitioning of rainfall into throughfall, stemflow and interception was associated with stand structural characteristics. Best correlations were found for interception with mean tree height, with stem density of large stems and particularly with a combination of tree height and leaf area index.

(iv) Rainfall intensity and altered forest structure complementarily influenced the patterns of rainfall partitioning. Throughfall measurements with different spatial and temporal resolution were necessary to clearly analyze these effects individually.

(v) Leaf wetness duration varied with different rainfall conditions and with the vertical distribution of foliage. Leaf wetness tended to last longer in the lower than in the upper canopy and its long duration reduced the available canopy water storage for interception between successive storms. 


\section{References}

Achard F, Eva H, Glinni A, Mayaoux P, Richards T, Stibig HJ (1998) Identification of deforestation hot spot areas in the humid tropics. TREES Publication Series B4, European Commission, Luxembourg.

Aiba SI, Kitayama K (2002) Effects of the 1997-98 El Niño drought on rain forests of Mount Kinabalu, Borneo. J Trop Ecol 18: 215-230.

Aragão LEOC, Shimabukuro YE, Espírito Santo FDB, Williams M (2005) Landscape pattern and spatial variability of leaf area index in Eastern Amazonia. For Ecol Manage 211: $240-256$.

Asdak C, Jarvis PG, van Gardingen P, Fraser A (1998) Rainfall interception loss in unlogged and logged forest areas of Central Kalimantan, Indonesia. J Hydrol 206: 237-244.

Asner GP, Knapp DE, Broadbent EN, Oliveira PJC, Keller M, Silva JN (2005) Selective logging in the Brazilian Amazon. Science 310: 480-482.

Asner GP, Scurlock JMO, Hicke JA (2003) Global synthesis of leaf area index observations: implications for ecological and remote sensing studies. Global Ecol Biogeogr 12: 191-205.

Aussenac G (1970) Action du couvert forestier sur la distribution au sol des précipitation. Ann For Sci 27: 383-399.

Baker PA，Seltzer GO，Fritz SC，Dunbar RB，Grove MJ，Tapia PM，Cross SL，Rowe HD, Broda JP (2001) The History of South American Tropical Precipitation for the Past 25,000 Years. Science 291: 640-643.

Bawa KS, Seidler R (1998) Natural Forest Management and Conservation of Biodiversity in Tropical Forests. Conserv Biol 12: 46-55.

Bos MM, Höhn P, Saleh S, Büche B, Buchori D, Steffan-Dewenter I, Tscharntke T (2007) Insect diversity responses to forest conversion and agroforestry management. In: Tscharntke T, Leuschner Ch, Zeller M, Guhardja E, Bidin A (eds) The Stability of Tropical Rainforest Margins, linking Ecological, Economic and Social Constraints of Land Use and Conservation. Springer Verlag Berlin, 279-296.

Breda NJJ (2003) Ground-based measurements of leaf area index: a review of methods, instruments and current controversies. J Exp Bot 54: 2403-2417.

Brewer CA, Smith WK (1997): Patterns of leaf surface wetness for montane and subalpine plants. Plant Cell Environ. 20: 1-11.

Brewer CA, Smith WK, Vogelmann TC (1991) Functional interaction between leaf trichomes, leaf wettability and the optical properties of water droplets. Plant Cell Environ. 14: 955-962.

Brodbeck F (2004) Structure and Processes in Traditional Forest Gardens of Central Sulawesi, Indonesia. Cuvillier Verlag, Göttingen.

Bruenig EF (1996) Conservation and Management of Tropical Rainforests. An Integrated Approach to Sustainability. CAB International, $352 \mathrm{pp}$.

Bruijnzeel LA, Veneklaas EJ (1998) Climatic conditions and tropical montane forest productivity: the fog has not lifted yet. Ecology 79: 3-9. 
Bruijnzeel LA, Proctor J (1995) Hydrology and biochemistry of tropical montane cloud forests: what do we really know? In: Hamilton LS, Juvik JO, Scatena FN (eds) Tropical Montane Cloud Forests, Ecological Studies 110. Springer Verlag Berlin, 38-78.

Carlyle-Moses DE, Laureano JSF, Price AG (2004) Throughfall and throughfall spatial variability in Madrean oak forest communities of northeastern Mexico. J Hydrol 297: 124-135.

Chappell NA, Bidin K, Tych W (2001) Modelling rainfall and canopy controls on net-precipitation beneath selectively-logged tropical forest. Plant Ecol 153: 215-229.

Crockford RH, Richardson DP (2000) Partitioning of rainfall into throughfall, stemflow and interception: effect of forest type, ground cover and climate. Hydrol Proces. 14: 2903-2920.

Dietz J, Hölscher D, Leuschner Ch, Hendrayanto (2006) Rainfall partitioning in relation to stand structure in differently managed montane forest stands in Central Sulawesi, Indonesia. For Ecol Manage 237: 170-178.

Dietz J, Hölscher D, Leuschner Ch, Malik A, Amir MA (2007) Forest structure as influenced by different types of community forestry in a lower montane rainforest of Central Sulawesi, Indonesia. In: Tscharntke T, Leuschner Ch, Zeller M, Guhardja E, Bidin A (eds) The Stability of Tropical Rainforest Margins, linking Ecological, Economic and Social Constraints of Land Use and Conservation. Springer Verlag Berlin, 133-148.

Dietz J, Leuschner Ch, Hölscher D, Kreilein H (in press) Vertical patterns and duration of surface wetness in an old-growth tropical montane rainforest, Indonesia. Flora. doi:10.1016/j.flora.2006.03.004

van Dijk AIJM, Bruijnzeel LA (2001a) Modelling rainfall interception by vegetation of variable density using an adapted analytical model. Part 1. Model description. J Hydrol 247: 239-262.

van Dijk AIJM, Bruijnzeel LA (2001b) Modelling rainfall interception by vegetation of variable density using an adapted analytical model. Part 2. Model validation for a tropical upland mixed cropping system. J Hydrol 247: 230-238.

Drigo R (2004) Trends and patterns of tropical land use change. In: Bonnell M, Bruijnzeel LA (eds) Forests, water and people in the humid tropics. Cambridge University Press, 9-39.

Dykes AP (1997) Rainfall interception from a lowland tropical rainforest in Brunei. J Hydrol 200: 260-279.

Falk U (2004) Turbulent fluxes of $\mathrm{CO}_{2}, \mathrm{H}_{2} \mathrm{O}$ and energy in the atmospheric boundary layer above tropical vegetation investigated by Eddy covariance measurements. $\mathrm{PhD}$ thesis, University of Göttingen.

FAO (2001) Global forest resources assessment 2000. Main Report. FAO Rome, Forestry Paper 140.

FAO (2006) World reference base for soil resources 2006. A framework for international classification, correlation and communication. FAO Rome, World Soil Resources Report 103.

Fleischbein K, Wilcke W, Goller R, Valarezo C, Zech W, Knoblich K (2005) Rainfall interception in a lower montane forest in Ecuador: effects of canopy properties. Hydrol Process 19: 1355-1371.

Gash JHC (1979) An analytical model of rainfall interception of forests. Quart J Roy Met Soc 105: 43-55. 
Gradstein SR, Kessler M, Pitopang R (2007) Tree species diversity relative to human land uses in tropical rain forest margins in Central Sulawesi. In: Tscharntke T, Leuschner Ch, Zeller M, Guhardja E, Bidin A (eds) The stability of tropical rainforest margins, linking ecological, economic and social constraints of land use and conservation. Springer Verlag Berlin, 321-334.

Grote S (2006) Struktur eines submontanen tropischen natürlichen Regenwaldes bei Bariri auf der indonesischen Insel Sulawesi. Master thesis at the University of Göttingen, 76 pp.

Grip H, Fritsch JM, Bruijnzeel LA (2004) Soil and water impacts during forest conversion and stabilisation of new land use. In: Bonnell M, Bruijnzeel LA (eds), Forests, Water and People in the Humid Tropics. Cambridge University Press, 561-589.

Grubb PJ (1977): Control of forest growth and distribution on wet tropical mountains: with special reference to mineral nutrition. Ann Rev Ecol Syst 8: 83-107.

Hall RL (2003) Interception loss as a function of rainfall and forest types: stochastic modelling for tropical canopies revisited. J Hydrol 280: 1-12.

Hamann A, Barbon EB, Curio E, Madulid DA (1999) A botanical inventory of a submontane tropical rainforest on Negros Island, Philippines. Biodiv Conserv 8: 1017-1031.

Hastenrath S (1991) Climate dynamics of the Tropics. Kluwer Acad. Publishers, Dordrecht.

Häring V, Köhler S, Gerold G (2005) Ergebnisse der Bodenkartierung Toro, Nopu (Sulawesi, Indonesien) im Rahmen des SFB552 (STORMA). Göttingen, 40 pp.

Helmi I (2005) Local people are well-placed to develop zonation plans in Indonesia's Lore Lindu National Park. Tropical Forest Update 15: 31-32.

Hertel D, Leuschner Ch, Harteveld M, Wiens M (2007) Fine root mass, distribution and activity in disturbed primary forests and secondary forests of the moist tropics. In: Tscharntke T, Leuschner Ch, Zeller M, Guhardja E, Bidin A (eds) The stability of tropical rainforest margins, linking ecological, economic and social constraints of land use and conservation. Springer Verlag Berlin, 89-108.

Herwitz SR (1985) Interception storage capacities of tropical rainforest canopy trees. J Hydrol 77: 237252.

Hodnett M, da Silva LP, da Rocha H, Cruz Senna R (1995) Seasonal soil water storage changes beneath central Amazonian rainforest and pasture. J Hydrol 170: 233-254.

Holwerda F, Scatena FN, Bruijnzeel LA (2006) Throughfall in a Puerto Rican lower montane rain forest: a comparison of sampling strategies. J Hydrol 327: 592-602.

Hölscher D, Mackensen J, Roberts JM (2005) Forest recovery in the humid tropics: changes in vegetation structure, nutrient pools and the hydrological cycle. In: Bonnell $\mathrm{M}$, Bruijnzeel LA (eds) Forests, water and people in the humid tropics. Cambridge University Press, 598-621.

Hölscher D, Köhler L, van Dijk AIJM, Bruijnzeel LA (2004) The importance of epiphytes to total rainfall interception by a tropical montane rainforest in Costa Rica. J Hydrol 292: 308-322.

Hölscher D, Sa TDD, Moller RF, Denich M, Fölster H (1998) Rainfall partitioning and related hydrochemical fluxes in a diverse and in a monospecific (Phenakospermum guyannense) secondary vegetation stand in eastern Amazonia. Oecologia 114: 251-257. 
Imbach AC, Fassbender HW, Bore R, Beer J, Bornemann A (1989) Modelling agroforestry systems of cacao (Theobroma cacao) with laurel (Cordia alliodora) and cacao with poro (Erythrina poeppigiana) in Costa Rica - IV. Water balances, nutrient inputs and leaching. Agroforest Syst 8: 267-287.

Jonckheere I, Fleck S, Nackaerts K, Muys B, Coppin P, Weiss M, Baret F (2004) Review of methods for in situ leaf area index determination Part I. Theories, sensors and hemispherical photography. Agri Forest Meteor 121: 19-35.

Keil A, Kleinhans A, Schwarze S, Birner R, Gerold G, Lipu S (2003) Forest conversion, Water Availability and Water Use in Central Sulawesi, Indonesia. Erde 134: 411-427.

Keim RF, Skaugset AE, Weiler M (2005) Temporal persistence of spatial patterns in throughfall. J Hydrol 315: 263-274.

Kelliher FM, Leuning R, Schulze ED (1993) vaporation and canopy characteristics of coniferous forests and grasslands. Oecologia 95: 153-163.

Kessler M, Keßler PJA, Gradstein SR, Bach K, Schmull M, Pitopang R (2005) Tree diversity in primary forests and different land use systems in Central Sulawesi, Indonesia. Biodiv Conserv 14: 547-560.

Kimmins JP (1973) Some statistical aspects of sampling throughfall precipitation in nutrient cycling studies in British Columbian coastal forests. Ecol 54: 1008-1019.

Kitamura S, Suzuki S, Yumoto T, Chuailua P, Plongmai K, Poonswad P, Noma N, Maruhashi T, Suckasam C (2005) A botanical inventory of a tropical seasonal forest in Khao Yai National Park, Thailand: implications for fruit-frugivore interactions. Biodiv Conserv 14: $1241-1262$.

Klemm O, Milford C, Sutton MA, Spindler G, van Putten E (2002) A climatology of leaf surface wetness. Theor Appl Climatol 71: 107-117.

Köhler L, Hölscher D, Leuschner Ch (2006) Above-ground water and nutrient fluxes in three successional stages of Costa Rican montane oak forest with contrasting of epiphyte abundance. In: Kappelle M (ed) Ecology and Conservation of Neotropical Montane Oak Forests. Springer Verlag Berlin, 271-282.

Koop H, Rijksen HD, Wind J (1995) Tools to diagnose forest integrity: an appraisal method substantiated by Silvi-Star assessment of diversity and forest structure. In: Boyle TJB, Boontawee B (eds) Measuring and Monitoring Biodiversity in Tropical and Temperate Forests. CIFOR, Bogor, Indonesia, 309-333.

Kramer H, Akça A (2002) Leitfaden zur Waldmeßlehre. Sauerländer Verlag, Frankfurt.

Kumagai T, Saitoh TM, Sato Y, Takahashi H, Manfroi OJ, Morooka T, Kuraji K, Suzuki M, Yasunari T, Komatsu H, (2005). Annual water balance and seasonality of evapotranspiration in a Bornean tropical rainforest. Agric For Meteor 128: 81-92.

Kummerow C, Simpson J, Thiele O, Barnes W, Chang ATC, Stocker E, Adler RF, Hou A, Kakar R, Wentz P, Ashcroft P, Kozu T, Hong Y, Okamoto K, Iguchi T, Kuroiwa H, Im E, Haddad Z, Huffman G, Ferrer B, Olson WS, Zipser E, Smith EA, Wilheit TT, North G, Krishnamurti T, Nakamura K (2000) The Status of the Tropical Rainfall Measuring Mission (TRMM) after Two Years in Orbit. J Appl Meteor 39: 1965-1982.

van Laar A, Akça A (1997) Forest Mensuration. Göttingen.

Legendre P (2000) Comparison of permutation methods for the partial correlation and partial mantel tests. J Statist Comp Simul 67: 37-73. 
Letts MG, Mulligan M (2005) The impact of light quality and leaf wetness on photosynthesis in north-west Andean tropical montane cloud forest. J Trop Ecol 21: 549557.

Leuschner Ch (2002) Air humidity as an ecological factor for woodland herbs: leaf water status, nutrient uptake, leaf anatomy and productivity of eight species when grown at low or high VPD. Flora 197: 262-274.

Leuschner Ch, Schulte M (1991) Microclimatological investigations in the tropical alpine scrub of Maui, Hawaii: evidence for a drought-induced alpine timberline. - Pac Sci 45: 152-168.

Leuschner Ch, Wiens M, Harteveld M, Hertel D, Tjitrosemito S (2006) Patterns of fine root mass and distribution along a disturbance gradient in a tropical montane forest, Central Sulawesi (Indonesia). Plant and Soil 283: 163-174.

Llorens P, Poch R, Latron J, Gallart F (1997) Rainfall interception by a Pinus sylvestris forest patch overgrown in a Mediterranean mountainous abandoned area. 1. Monitoring design and results down to the event scale. J Hydrol 199: 331-345.

Lloyd CR, Marques A de OF (1988) Spatial variability of throughfall and stemflow measurements in Amazonian rainforest. Agric For Meteor 42: 63-73.

Loustau D, Berbigier P, Granier A, Moussa FE (1992) Interception loss, throughfall and stemflow in a maritime pine stand.1. Variability of throughfall and stemflow beneath the pine canopy. J Hydrol 138: 449-467.

Magarey RD, Russo JM, Seem RC, Gadoury DM (2005) Surface wetness duration under controlled environmental conditions. - Agric For Meteorol 128: 111-122.

Manfroi OJ, Koichiro K, Nobuaki T, Masakazu S, Nakagawa M, Nakashizuka T, Chong L (2004) The stemflow of trees in a Bornean lowland tropical forest. Hydrol Process 18: 2455-2474.

Manfroi OJ, Koichiro K, Suzuki M, Tanaka N, Kume T, Nakagawa M, Kumaigai T, Nakashizuka T (2006) Comparison of conventionally observed interception evaporation in a $100-\mathrm{m}^{2}$ subplot with that estimated in a 4-ha area of the same Bornean lowland tropical forest. J Hydrol 329: 329-349.

McElhinny C, Gibbons P, Brack C, Bauhus J (2005) Forest and woodland stand structural complexity: Its definition and measurement. For Ecol Manage 218: 1-24.

Migge-Kleian S, Woltmann L, Schaefer M (2007) Impact of forest disturbance and land use change on soil and litter arthropod assemblages in tropical rainforest margins. In: Tscharntke T, Leuschner Ch, Zeller M, Guhardja E, Bidin A (eds) The stability of tropical rainforest margins, linking ecological, economic and social constraints of land use and conservation. Springer Verlag Berlin, 149-165.

Moench M (1991) Soil erosion under a successional agroforestry sequence: a case study from Idukki District, Kerala, India. Agroforest Syst 15: 31-50.

Nieschulze N, Erasmi S, Dietz J, Malik A, Hölscher D (in prep.) The use of satellite images for the estimation of rainfall interception from managed forest stands in Central Sulawesi (Indonesia).

Presslan AJ (1973) Rainfall Partitioning by an Arid Woodland (Acacia aneura F-Muell) in SouthWestern Queensland. Austral J Bot 21: 235-245.

Roberts JM, Gash JHC, Tani M, Bruijnzeel LA (2004) Controls on evaporation in lowland tropical rainforest. In: Bonnell M and Bruijnzeel LA (eds) Forests, water and people in the humid tropics. Cambridge University Press, 287-313. 
Ruf F, Schroth G (2004) Chocolate forests and monocultures: A historical review of cocoa growing and its conflicting role in tropical deforestation and forest conservation. In: Schroth G, da Fonseca GAB, Harvey CA, Gascon C, Vasconcelos HL, Izac AMN (eds) Agroforestry and biodiversity conservation in tropical landscapes. Island Press, Washington, 107-134.

Rutter AJ, Kershaw KA, Robins PC, Morton AJ (1971) A predictive model of rainfall interception in forests: I. Derivation of the model from observations in a plantation of Corsican pine. Agric Meteorol 9: 367-384.

Schroth G, Ferreira da Silva L, Wolf MA, Teixeira WG, Zech W (1999) Distribution of throughfall and stemflow in multi-strata agroforestry, perennial monoculture, fallow and primary forests in central Amazonia, Brazil. Hydrol Process 13: 1423-1436.

Schweithelm J (2004) Forest people and changing tropical forestland use in tropical Asia. In Bonnell M, Bruijnzeel LA (eds) Forests, water and people in the humid tropics. Cambridge University Press, 66-74.

Soulé ME, Sanjayan MA (1998) Conservation Targets: Do They Help? Science 279: 2060-2061.

Sri-Gernyuang K, Kanzaki M, Mizuno T, Noguchi H, Teejuntuk S, Sungpalee C, Hara M, Yamakura T, Sahunalu P, Dhanmanonda P, BunyavejchewinS (2003) Habitat differentiation of Lauraceae species in a tropical lower montane forest in northern Thailand. Ecol Res 18: 1-14.

Takyu M, Aiba SI, Kitayama K (2002) Effects of topography on tropical lower montane forests under different geological conditions on Mount Kinabalu, Borneo. Plant Ecol 159: 35-49.

Tobón Marin C, Bouten W, Sevink J (2000) Gross rainfall and its partitioning into throughfall, stemflow and evaporation of intercepted water in four forest ecosystems in western Amazonia. J Hydrol 237: 40-57.

Trichton V, Walter JMN, Laumonier Y (1998) Identifying spatial patterns in the tropical rain forest structure using hemispherical photographs. Plant Ecol 137: 227-244.

Urban DL (2003) Spatial Analysis in Ecology. Pattern, Process and Scale. 7 pp.

Weiss M (2002) EYE-CAN User Guide. NOV-3075-NT-1260. NOVELTIS, Toulouse, France.

Wallace AR (1869) The Malay Archipelago. Paperback edition Periplus Ltd., 515 pp.

Walter H, Harnickell E, Mueller-Dombois D (1975) Climate-diagram Maps of the Individual Continents and the Ecologic Climatic Regions of the Earth: Supplement to the Vegetation Monographs. Springer Verlag, Berlin. 


\section{Publications}

7.1 Dietz J, Hölscher D, Leuschner Ch, Malik A, Amir MA (2007)

Forest structure as influenced by different types of community forestry in a lower montane rainforest of Central Sulawesi, Indonesia.

In: Tscharntke T, Leuschner Ch, Zeller M, Guhardja E, Bidin A (eds) The stability of tropical rainforest margins, linking ecological, economic and social constraints of land use and conservation. Springer Verlag Berlin, 133-148.

7.2 Dietz J, Hölscher D, Leuschner Ch, Hendrayanto (2006)

Rainfall partitioning in relation to stand structure in differently managed montane forest stands in Central Sulawesi, Indonesia.

In: Forest Ecology and Management 237: 170-178.

doi:10.1016/ j.foreco.2006.09.044

\subsection{Dietz J, Leuschner Ch, Hölscher D, Kreilein H (in press)}

Vertical patterns and duration of surface wetness

in an old-growth tropical montane forest, Indonesia.

In: Flora (FLORA50103)

doi:10.1016/j.flora.2006.03.004

\subsection{Klank Ch, Dietz J, Hölscher D, Leuschner Ch (under review)}

Spatial and temporal variability of throughfall

in a tropical old-growth forest and an agroforestry system

in Sulawesi (Indonesia).

In: Agroforestry Systems (AGFO176) 


\title{
Forest structure as influenced by different types of community forestry in a lower montane rainforest of Central Sulawesi, Indonesia
}

\author{
Johannes Dietz ${ }^{1,2 *}$, Dirk Hölscher ${ }^{1}$, Christoph Leuschner ${ }^{2}$, Adam Malik $^{3}$, \\ and M. Amran Amir ${ }^{3}$ \\ 1 Tropical Silviculture, Institute of Silviculture, University of Göttingen, \\ Büsgenweg 1, 37077 Göttingen, Germany \\ 2 Plant Ecology, Albrecht-von-Haller-Institute for Plant Sciences, University of \\ Göttingen, Untere Karspüle 2, 37073 Göttingen, Germany \\ 3 Institute of Forest Management, Faculty of Agriculture, Bumi Tondo Campus, \\ Tadulako University, Palu 94118, Indonesia \\ *corresponding author: Johannes Dietz, phone +49 (0)551 399556, fax: +49 \\ (0)551 394019, Email: jdietz@gwdg.de
}

\section{Summary}

Due to high deforestation rates, it is likely that in many regions tropical rainforests will survive in protected areas only. These refuges have to be surrounded by buffer zones where low impact forest management is permitted. In fact, increasing parts of the remaining rainforest areas are encroached by different types of low-intensity forest use. However, until now only few data exist on how different practices affect forest structure. The objectives of this study were to analyze differences in aboveground forest stand structure as caused by different types of forest utilization in the margin zone of a protected rainforest. The study was conducted in a lower montane rainforest region $(800-1140 \mathrm{~m})$ in the vicinity of the village of Toro in Central Sulawesi, Indonesia. We assessed the structure of twelve forest plots ( 0.15 ha each) which represented four types of forest use which are widespread in the study region. These types were natural forest without major disturbance, forest extraction of small-diameter timber, forest with selective extraction of large timbers and cacao agroforest plantations under trees remaining from the natural forest. The tree basal area ranged from relatively high values in the natural forests $\left(52.5 \mathrm{~m}^{2}\right.$ per ha) to $19.4 \mathrm{~m}^{2}$ per ha in the agroforest, and was paralleled by a decrease in tree height. Stem density peaked in stands where large timbers had been extracted

Tscharntke T, Leuschner C, Zeller M, Guhardja E, Bidin A (eds), The stability of tropical rainforest margins, linking ecological, economic and social constraints of land use and conservation, Springer Verlag Berlin 2007, pp 133-148 
and abundant tree regeneration had resumed, and it was lowest in the agroforest stands. Canopy openness, as estimated from 30 hemispheric photographs per plot, was lowest in the natural forest after small timber extraction (7\%) and highest in cacao agroforest $(15 \%)$. Leaf area index (LAI), as estimated from the same photos, averaged to $6.2 \mathrm{~m}^{2} \mathrm{~m}^{-2}$ in the natural forest, $5.3 \mathrm{in}$ the forests with small timber extraction, 5.0 in the forests with large timber extraction, and 5.3 on the agroforest plots. The latter result confirms earlier reports of relatively high leaf areas in the cacao agroforestry system. The relatively high LAI in forest stands after major timber extraction indicates a rapid recovery of leaf area after disturbance. We also analyzed the influence of stand structural parameters on rainfall partitioning into throughfall, stemflow and interception. In all forest stands we observed a close negative correlation between mean throughfall and tree height $\left(r^{2}=0.63\right)$ indicating a higher interception loss in taller stands. We conclude that local forest management at low to moderate intensities, as it is common in the margin zones of protected forests, has a significant and quantifiable impact on several forest structural parameters which in turn may influence ecosystem functions such as rainfall partitioning in the canopy.

Key words: forest use, leaf area index, rainfall partitioning, rainforest, stand structure, stem density

\section{Introduction}

Over the past decades, tropical rainforests have been suffering increasing losses by conversion to other land cover types. South East Asia and especially some regions on the Indonesian archipelago including Central Sulawesi were identified as areas with high deforestation rates (Achard et al. 1998, Drigo 2004, FAO 2001). However, more subtle forms of forest disturbance as by selective logging on conservation lands are difficult to identify via satellite and are assumed to be underestimated so far (Asner et al. 2005). Based on recent analyses for five states of the Brazilian Amazon, selective logging doubled previous estimates of the total amount of forest degraded by human activities (Asner et al. 2005).

The high rates of forest conversion together with the rapidly proceeding forest degradation have long since called upon conservation efforts. It has been emphasized that protection requires the interaction with the people that traditionally live in and around the forests (Schweithelm 2004). Contemporary policies advocate buffer zone management by a low impact forest management which, according to Schweithelm (2004), can be developed from the experience of traditional communities that regulate the access to land and forest resources. For the Lore Lindu National Park in Central Sulawesi, such traditional structures and regulations are found in the village of Ngata Toro (Helmi 2005). There, customary law has created a zonation of the forest into different 
use types which are distinguished by the local population. According to Helmi (2005), the "Wana" type of community forestry is predominantly a natural forest where only occasional rattan extraction takes place. In the "Pangale" small-diameter timbers can be extracted in the understorey, or alternatively, a restricted number of large stems can be selectively logged. Strong human intervention is characteristic for the "Pahawa Pongko" zone, which comprises cacao agroforests under a sparse canopy of large trees that remain from the natural forest (Helmi, 2005).

However, such definitions of land use are subjective and there is a need to quantify such categories by objective means (cf. Drigo 2004). Drigo (2004) suggests the translation from land use practice to land cover types where structural characteristics can be measured and monitored. Following this suggestion, the objective of our study was to identify and quantify the impact of different forest use practices on the stand structure of a lower montane rainforest in the region of the Toro village, Central Sulawesi. In a further study we analyzed the influence of stand structural parameters on rainfall partitioning into throughfall, stemflow and interception in order to relate stand structural characteristics to forest functions with respect to the hydrological cycle.

\section{Materials and Methods}

\subsection{Study Site}

This study was carried out in tropical rainforests of the sub-montane to lower montane elevation zone ( 800 - $1140 \mathrm{~m}$ a.s.l.) in the Toro Valley on the western boundary of the Lore Lindu National Park, Central Sulawesi, Indonesia. Twelve sites of $1500 \mathrm{~m}^{2}$ each were chosen for the study, evenly representing all four investigated forest use types $(n=3)$ : natural forest, forest with extraction of small-diameter timbers (hereafter termed 'small timber extraction'), forest with selective extraction of large timbers (hereafter termed 'large timber extraction'), and cacao plantations under trees remaining from the natural forest (agroforest). The four forest use types (natural forest to agroforest) generally occurred in the vicinity of the Village of Toro along a gradient of accessibility with natural forest being most distant and agroforest closest to the settlements. During the investigation period no management was observed on the forested sites while the cacao agroforests received conventional treatment of weeding and pruning. All sites were situated on moderately to severely steep slopes from $17^{\circ}$ to $39^{\circ}$. The tree species composition in these forest types was studied by Gradstein et al. (this volume). They found Meliaceae, Lauraceae, and Sapotaceae to be dominant in natural forests, which shifted to Rubiaceae, Fagaceae, and Myristicaceae after both, small and large timber extraction. Moraceae, Myristicaceae, and Melastomataceae dominated in the investigated agroforests. The tree species richness varied little between natural forest stands and after small timber extraction, but was lower in stands 
after large timber extraction and lowest in the agroforests (Gradstein et al. this volume).

\subsection{Stand Inventory}

On the forested sites, all trees with a diameter at breast height (dbh) of $10 \mathrm{~cm}$ or more were censused for dbh and height on the entire plot according to Kramer and Akça (1995). To account for smaller statured trees all individuals with $\mathrm{dbh}<10 \mathrm{~cm}$, but higher than $2 \mathrm{~m}$, were assessed on three randomly located subplots of $5 \times 5 \mathrm{~m}$ within the plot. In the agroforests, all stems taller than $2 \mathrm{~m}$ were censused. Measurement of dbh was done using a metric measuring tape, height measurements were taken with a Vertex III ultrasonic hypsometer (Haglöf, Långsele, Sweden). Stand basal area was corrected for edge and slope effects.

\subsection{Hemispherical Photography}

Data on canopy structure was derived from hemispherical photographs which were obtained with a Nikon Coolpix 900 digital camera / Nikon FC-E8 fisheyeconverter of 2048 x 1536 pixel resolution mounted on a HemiView leveling device (Delta-T, Cambridge, UK). For reduction of horizon effects on the sloped sites, the device was consistently placed at $1.3 \mathrm{~m}$ above the ground. Thirty pictures per site and campaign were taken at randomly located points on several occasions during the study period from January 2004 until April 2005. All images were analyzed with the software WinScanopy 2004a (Régent Instruments Inc., Sainte-Foy, Canada) for canopy openness under an opening angle of $30^{\circ}$, and with CanEye V 3.6 (INRA, Avignon, France) for estimates of leaf area index (LAI).

\subsection{Statistical Analysis}

Data were statistically analyzed using the SAS 8.2 software package (SAS Institute Inc., Cary, NC, US). Multiple comparisons among group means were conducted by analyses of variance (Duncan's test); a significance level of $p<0.05$ was maintained throughout the analysis.

\section{Results and Discussion}

\subsection{Stem Density}

Koop et al. (1995) recognized the density of large trees as a good estimator for human influence on Sumatran rainforests. In our study region, the density of large stems with a diameter at breast height (dbh) larger than $50 \mathrm{~cm}$ also 


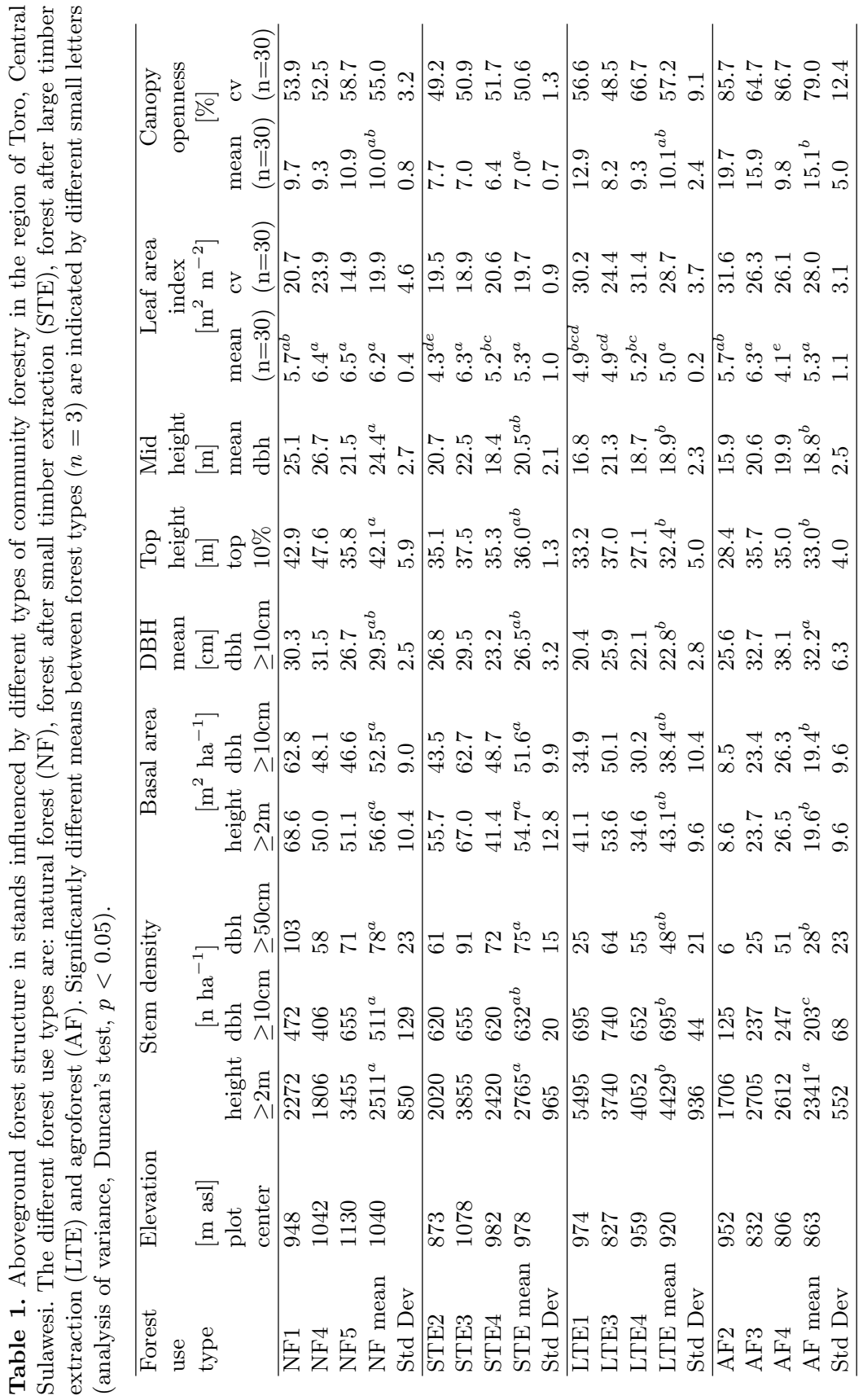


appeared as good indicator of the intensity of forest use (Figure 1, solid bars). Highest values averaging at 78 and 75 stems per hectare were found in the natural forest and in forest after small timber extraction. Large timber extraction reduces the density to 48 stems per hectare. Agroforests contained an average of only 28 large trees per hectare (ranging between 6 and 51 stems per hectare, Table 1). The very large variability in the density of large-diameter stems in the agroforestry systems may be related to the personal experience and preference of the plot owners. A similar structural diversity in agroforestry systems was previously documented for other tropical regions by Ruf and Schroth (2004). Small stems ( $<10 \mathrm{~cm}$ in $\mathrm{dbh}$ ) averaged slightly above 2000 stems per hectare in the natural forest, but reached higher values after large timber extraction (Figure 1, hatched bars). In the gaps created by logging of big trees, abundant regrowth occurred with 3700 stems per hectare on the average. In the agroforest, the class of small stems included most of the planted cacao (Theobroma cacao) trees.

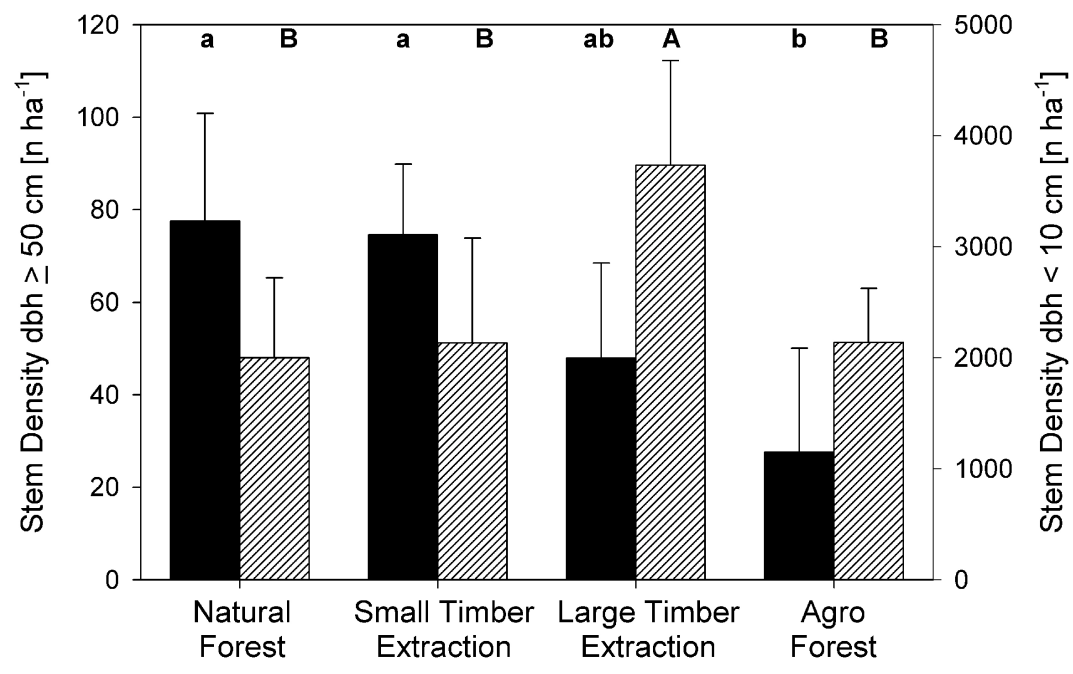

Fig. 1. Stem densities in four different forest use types. Number of all stems with diameter at breast height $(\mathrm{dbh}) \geq 50 \mathrm{~cm}$ (solid bars, left) and $\mathrm{dbh}<10 \mathrm{~cm}$ per hectare (hatched bars, right) 

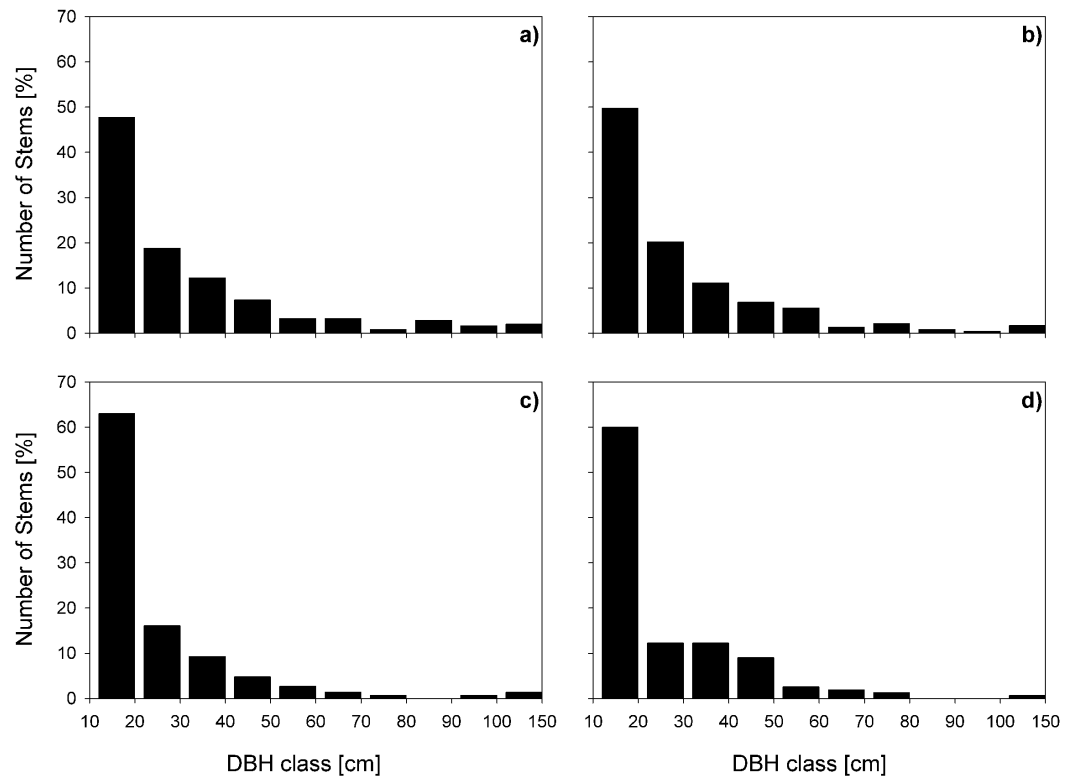

Fig. 2. Diameter distribution of all stems with $\mathrm{dbh} \geq 10 \mathrm{~cm}$ in natural forest (a), after small timber extraction (b), after large timber extraction (c), and in agroforest (d)

Few remaining large trees and a high proportion of small stems were characteristic for both forest stands after large timber extraction and agroforest stands. This contrasted with natural forest stands and stands after small timber extraction. In the latter, the dbh class $<20 \mathrm{~cm}$ contained less than $50 \%$ of all stems, (Figures 2a and b), whereas after large timber extraction the proportion of trees in this diameter class reached values above $60 \%$. In the agroforest, the high proportion of thin stems mostly owed to planted crop trees (Figures 2c and d). Big trees were scarce in these two forest use types.

\subsection{Basal Area and Stand Height}

The abundance of large-diameter stems is known to be a good estimator of a stand's basal area of stems $\geq 10 \mathrm{~cm}$ dbh (McElhinny et al. 2005). Average basal areas of 52.5 and $51.6 \mathrm{~m}^{2}$ per hectare in the natural forest and in stands after small timber extraction, respectively, seem to be relatively high, especially when the peak value of $62.8 \mathrm{~m}^{2} \mathrm{ha}^{-1}$ is considered. However, a comparison with other studies in natural forests above $600 \mathrm{~m}$ asl in the South East Asian region reveals that the values for the natural forests in Toro are indeed 


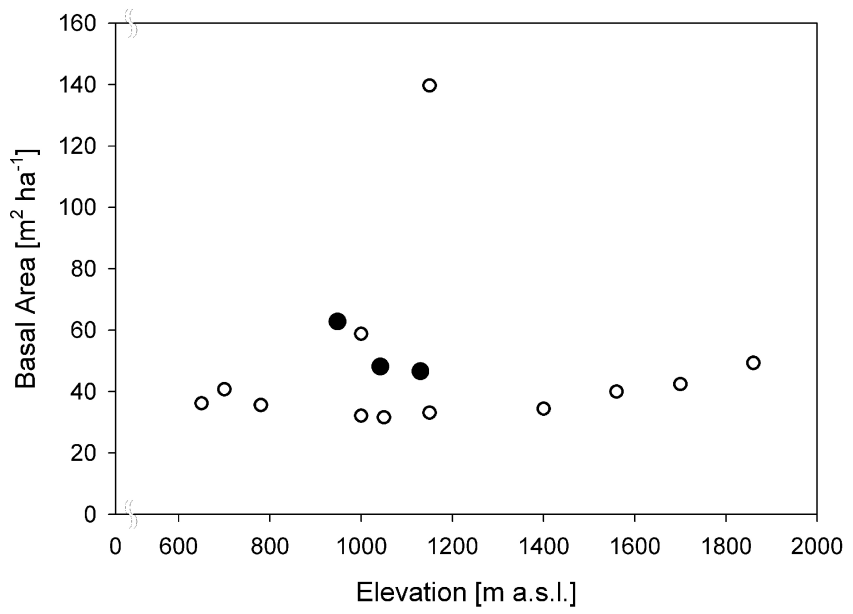

Fig. 3. Basal area of natural forests in the region of Toro, Central Sulawesi (this study, -), compared to results from other studies in natural forests of South East Asia ( O) above $600 \mathrm{~m}$ asl. Sources: Aiba and Kitayama 2002, Brodbeck 2004, Dietz et al. unpublished data, Hamann et al. 1999, Kessler et al. 2005, Kitamura et al. 2005, Sri-Gernyuang 2003

slightly above the average, yet they are still within the reported range (Figure 3). In our study region, the average basal area decreased to $38.4 \mathrm{~m}^{2} \mathrm{ha}^{-1}$ in stands after large timber extraction and dropped to $19.4 \mathrm{~m}^{2} \mathrm{ha}^{-1}$ in the agroforest. The decrease in tree basal area along the gradient of use intensity was paralleled by a decrease in tree height. The stand mid height, which is the height of a tree with the arithmetic mean of dbh (Kramer and Akça 1995), decreased from $24.4 \mathrm{~m}$ in the natural forest and from $20.5 \mathrm{~m}$ in stands after small timber extraction to $18.9 \mathrm{~m}$ in stands after large timber extraction and $18.8 \mathrm{~m}$ in the agroforest. The apparent drop in tree mean height between natural forest and forest after small timber extraction is statistically not significant. If existent, it may be caused by slight changes in environmental conditions between sites (cf. Takyu et al. 2002).

\subsection{Leaf Area Index and Canopy Openness}

Leaf area index (LAI) is a basic variable for modeling the energy and matter fluxes in forests; this parameter is also of great importance for vegetation models in the context of global change research (e.g. Asner et al. 2003). A variety of different assessment methods are used in the field (Breda 2003, Jonckheere et al. 2004). A consistent underestimation of LAI by indirect methods such as 
hemispheric photography was reported by Breda (2003) but their growing potential was acknowledged. On the global scale, Asner et al. (2003) confirmed that indirect optical measurements of LAI were closer to the results from destructive assessments than interpolations derived from litter sampling or estimates obtained from allometric functions. The destructive sampling approach would have been very labor-intensive and would have conflicted with conservation policies in our forest plots, which are located in a national park. Since hemispheric photography is a rapid, sufficiently reliable and non-destructive approach for the assessment of canopy structure (Jonckheere et al. 2004), it was thus chosen in our study.

The LAI of evergreen forests may change seasonally with rainfall volumes and other climatic parameters (Asner et al. 2003, Breda 2003). Therefore, we analyzed most stands for their leaf area at three different times. However, in none of the stands, a distinct seasonality in LAI was observed (see Figure 4a for the LAI of a natural forest). This may be due to the largely non-seasonal rainfall distribution in the study region. The following results are based on photos taken during a measurement campaign in April 2005.

The LAI as derived from 30 photos within a plot varied only moderately in space within a plot. In the natural forest, the coefficient of variation (CV) ranged between 15 and $24 \%$ which is similar to results found in natural forests of the Brazilian Amazon using a different, yet quite comparable method (Licor LAI 2000; Aragão et al. 2005). In our study region, the CV values in forest stands after large timber extraction and the agroforest stands ranged from 24 to $32 \%$. This corresponds with CVs measured in Amazonian secondary forests (Aragão et al. 2005). The average LAI of the natural forest stands in Sulawesi ranged from 5.7 to $6.5 \mathrm{~m}^{2} \mathrm{~m}^{-2}$. In their global review Asner et al. (2003) reported a mean ( \pm SD) LAI of 4.9 (2.0) for tropical evergreen broadleaf forests. Aragão et al. (2005) found values between 3.6 and 6.6 for natural forest in Amazonia, Trichon et al. (1998) reported values between 3.9 and 6.1 from rainforests in Sumatra, and similarly Kumagai et al. (2004) found values between 4.8 and 6.8 in Borneo. Roberts et al. (2004) obtained LAI values ranging from 4.1 to 8.0 for tropical lowland rainforests, with a tendency for higher values in Asia. Thus, the values obtained in Sulawesi are well within the range of other studies and they may also support slightly higher values in Asian tropical forests (Roberts et al. 2004). The average LAI of a given forest use type was $6.2 \mathrm{~m}^{2} \mathrm{~m}^{-2}$ in the natural forest, 5.3 in forests with small timber extraction, 5.0 in forests with large timber extraction, and 5.3 in the agroforest. The variation between plots of the same use type was largest in the agroforestry systems, where values between 4.1 and 6.3 were observed (Figure $4 \mathrm{~b}$ ). The large variability between the agroforest sites may be explained with the already mentioned densities of large and small stems that differ greatly under permanent human influence (Ruf and Schroth 2004). Our relatively high average LAI values for agroforest confirm studies claiming that plantations in general (Asner et al. 2003), and cacao in Central Sulawesi in particular (Falk 2004), can maintain a comparably large leaf area. The relatively high LAI val- 

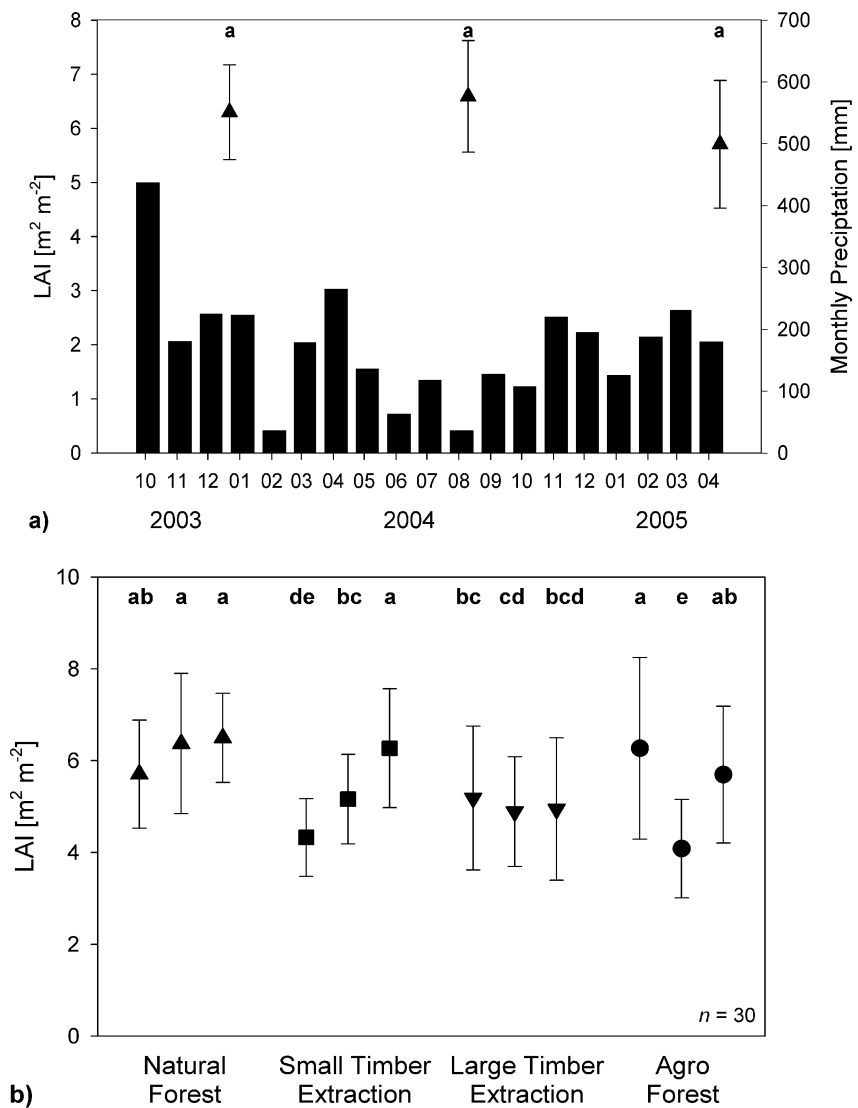

Fig. 4. Leaf area index (LAI) estimates from a natural forest on three different dates compared to the monthly rainfall volumes (a), and LAI values with standard deviation for all twelve plots grouped by forest use types (b); $(n=30$ photos per stand, analysis of variance, Duncan's test $p<0.05$ )

ues in managed stands of Sulawesi are comparable to results from Amazonia, where only little differences in LAI between natural forests and selectively logged sites were observed (Aragão et al. 2005). The high proportion of regrowth after large timber extraction may contribute substantially to such high LAI values in Sulawesi.

The average canopy openness, as determined from photographs taken at $1.3 \mathrm{~m}$ above the ground, was between 10 and $11 \%$ per site in the natural forest; it was considerably higher in cacao agroforest (between 16 and 20\%; 
Table 1). The values obtained in the forest stands after small and large timber extraction did not differ significantly from those in the natural forest. Trichton et al. (1998) found canopy openness values below $10 \%$ in mature Sumatran rainforests but they report much larger values for gap phases. Tobón Marin et al. (2000) found canopy openness values from 9 to $17 \%$ in natural rainforests of western Amazonia. In the agroforest systems of Sulawesi, many large trees have been removed arbitrarily and to different extents by the plantation owners who subsequently plant crop trees in different densities. Thus, in the agroforest, we found the highest average canopy openness which was associated with a relatively high spatial variation in this parameter in a given stand and between different stands (Table 1 ).

\section{Outlook - the relationship between stand structure and ecosystem functions}

The aboveground structure of tropical forests has been shown to influence many ecosystem properties that control energy and matter fluxes, including radiation transmission, the temperature regime, the atmospheric saturation deficit (Leigh 1975, Montgomery 2004, Parton et al. 1996, Trichon et al. 1998), soil temperature, fine root biomass and turnover (Hertel et al. this volume), as well as the diversity of the soil fauna (Migge-Kleian et al. this volume) and of butterflies (Fermon et al. 2005). Forest structure is also considered to be an important parameter in the hydrological cycle of forests (e.g. Bigelow 2001, Bruijnzeel et al. 1993, Chappell et al. 2001, Hall 2003, Hölscher et al. 2004).

In our study plots in Central Sulawesi, we monitored throughfall with 30 funnel collectors each on all 12 plots, stemflow with 10 collectors per plot, and gross rainfall with rain gauges adjacent to each plot. The throughfall median was $70 \%$ of incident precipitation in natural forest, $79 \%$ in forest with small timber extraction, and $80 \%$ in forest with large timber extraction and $81 \%$ in the agroforest. Stemflow was estimated to be less than $1 \%$ in all studied forest use types. Among the stand structural parameters that correlate with rainfall partitioning we found the best correlation between throughfall and mean tree height (the arithmetic mean height of all stems $>10 \mathrm{~cm} \mathrm{dbh}$ ). Considering all 12 plots from all four forest use types, the coefficient of determination $\left(r^{2}\right)$ was 0.63 (Figure 5). We conclude that tree height is an easy-to-measure parameter that allows for an estimation of the throughfall volume along the disturbance gradient from natural forest to agroforest. In other studies, LAI has often been used for modeling the partitioning of rainfall into throughfall, stemflow and interception (Gash 1979, Gash et al. 1995), and has been described as a good parameter to estimate throughfall volumes (Hall 2003, Holwerda et al. in press). In contrast, LAI alone was not significantly correlated to throughfall (or rainfall interception) in our study. A possible explanation is that the total LAI and the associated canopy water storage differed only slightly between the studied stands while the vertical distribution of the foliage varied 


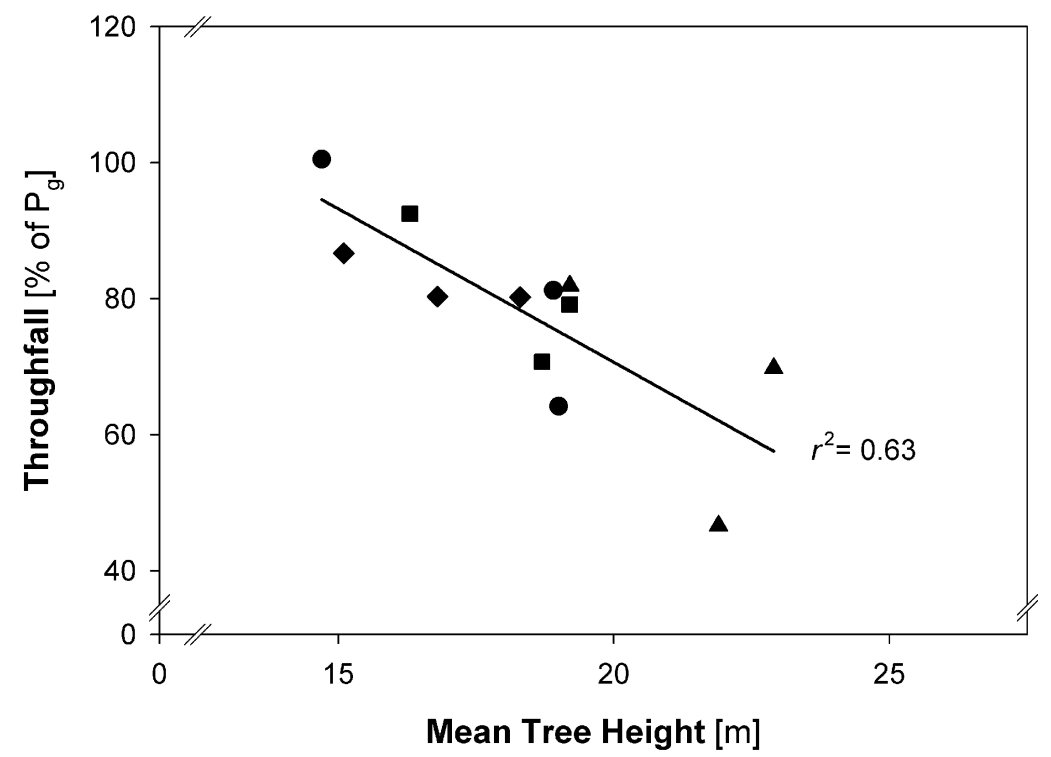

Fig. 5. Relationship between mean canopy height (arithmetic mean of all trees $\geq 10 \mathrm{~cm} \mathrm{dbh})$ and throughfall expressed in percent of gross rainfall $\left(\mathrm{P}_{\mathrm{g}}\right)$ for 15 days of rainfall per plot $\left(r^{2}=0.63, p<0.01\right)$. Considered in the regression are three natural forest plots $(\boldsymbol{\Lambda})$, three forests after small timber extraction $(\boldsymbol{\square})$, three forests after large timber extraction $(\bullet)$, and three agroforest sites $(\bullet)$.

greatly. Taller trees presumably increase the aerodynamic roughness length of the stand, resulting in a more effective turbulent energy exchange with the atmosphere. As a consequence, the canopy dries up more often between rainfall events in tall stands, while it remains wet for longer periods in stands with lower-statured trees and with a more clumped distribution of the leaf area.

\section{Conclusions}

We conclude that the different types of community forestry in Central Sulawesi changed stand structural characteristics considerably. We found strong effects on stem density, basal area and stand height, whereas the leaf area index seemed to be less affected. The changes in forest structure were associated with differences in the forest hydrological cycle as the volume of net precipitation increased with decreasing stand height. 


\section{Acknowledgements}

This study was conducted in the framework of the joint Indonesian-German research project "Stability of Tropical Rainforest Margins, Indonesia" (STORMA) funded by the German Science Foundation (SFB 552). We thank the village of Toro for their friendly help and cooperation and André Twele for substantial support in processing the hemispherical photographs.

\section{References}

Aiba SI, Kitayama K (2002) Effects of the 1997-98 El Niño drought on rain forests of Mount Kinabalu, Borneo. J Trop Ecol 18: 215-230

Aragão LEOC, Shimabukuro YE, Espírito Santo FDB, Williams M (2005) Landscape pattern and spatial variability of leaf area index in Eastern Amazonia. For Ecol Manage 211: 240-256

Achard F, Eva H, Glinni A, Mayaoux P, Richards T, Stibig HJ (1998) Identification of deforestation hot spot areas in the humid tropics. TREES Publication Series B4, European Commission, Luxembourg

Asner GP, Knapp DE, Broadbent EN, Oliveira PJC, Keller M, Silva JN (2005) Selective logging in the Brazilian Amazon. Science 310: 480-482

Asner GP, Scurlock JMO, Hicke JA (2003) Global synthesis of leaf area index observations: implications for ecological and remote sensing studies. Global Ecol Biogeogr 12: 191-205

Aylward B (2004) Land use, hydrological function and economic valuation. In: Bonnell M, Bruijnzeel LA (eds) Forests, water and people in the humid tropics. Cambridge University Press, Cambridge, pp 99-120

Bigelow S (2001) Evapotranspiration modeled from stands of three broadleaved tropical trees in Costa Rica. Hydrol Proc 15: 2779-2796

Breda NJJ (2003) Ground-based measurements of leaf area index: a review of methods, instruments and current controversies. J Exp Bot 54: 2403-2417

Brodbeck F (2004) Structure and Processes in Traditional Forest Gardens of Central Sulawesi, Indonesia. Cuvillier Verlag, Göttingen

Bruijnzeel LA, Waterloo MJ, Proctor J, Kuiters AT, Kotterink B (1993) Hydrological observations in montane rainforests on Gunung Silam, Sabah; Malaysia, with special reference to the 'Massenerhebung' effect. J Hydrol 81: 145-167

Chappell NA, Bidin K, Tych W (2001) Modelling rainfall and canopy controls on net-precipitation beneath selectively-logged tropical forest. Plant Ecol 153: $215-229$

Drigo R (2004) Trends and patterns of tropical land use change. In: Bonnell M, Bruijnzeel LA (eds) Forests, water and people in the humid tropics. Cambridge University Press, Cambridge, pp 9-39

Falk U (2004) Turbulent fluxes of $\mathrm{CO}_{2}, \mathrm{H}_{2} \mathrm{O}$ and energy in the atmospheric boundary layer above tropical vegetation investigated by Eddy covariance measurements. $\mathrm{PhD}$ thesis, University of Göttingen 
FAO (2001) Global forest resources assessment 2000. Main Report. FAO Forestry Paper 140

Fermon H, Waltert M, Vane-Wright RI, Mühlenberg M (2005) Forest use and vertical stratification in fruit-feeding butterflies of Sulawesi, Indonesia: impacts for conservation. Biodiv Conserv 14: 333-350

Gash JHC (1979) An analytical model of rainfall interception of forests. Quart J Roy Met Soc 105: 43-55

Gash JHC, Lloyd CR, Lachaud G (1995) Estimating sparse forest rainfall interception with an analytical model. J Hydrol 170: 79-86

Gradstein SR, Kessler M, Pitopang R (this volume) Tree species diversity relative to human land uses in tropical rain forest margins in Central Sulawesi. In: Tscharntke T, Leuschner C, Guhardja E, Zeller M, Bidin A (eds) The stability of tropical rainforest margins, linking ecological, economic and social constraints of land use and conservation. Springer, Berlin Heidelberg New York

Hall RL (2003) Interception loss as a function of rainfall and forest types: stochastic modelling for tropical canopies revisited. J Hydrol 280: 1-12

Hamman A, Barbon EB, Curio E, Madulid DA (1999) A botanical inventory of a submontane tropical rainforest on Negros Island, Philippines. Biodiv Conserv 8: 1017-1031

Hart MJ (1928) Stamtal en dunning. Dissertation, University of Wageningen

Helmi I (2005) Local people are well-placed to develop zonation plans in Indonesia's Lore Lindu National Park. Tropical Forest Update 15: 31-32

Hertel D, Leuschner C, Harteveld M, Wiens M (this volume) Fine root mass, distribution and activity in disturbed primary forests and secondary forests of the moist tropics. In: Tscharntke T, Leuschner C, Guhardja E, Zeller M, Bidin A (eds) The stability of tropical rainforest margins, linking ecological, economic and social constraints of land use and conservation. Springer, Berlin Heidelberg New York

Hölscher D, Mackensen J, Roberts JM (2004) Forest recovery in the humid tropics: changes in vegetation structure, nutrient pools and the hydrological cycle. In: Bonnell M, Bruijnzeel LA (eds) Forests, water and people in the humid tropics. Cambridge University Press, Cambridge, pp 598-621

Holwerda F, Scatena FN, Bruijnzeel LA (2006) Throughfall in a Puerto Rican lower montane rain forest: a comparison of sampling strategies. J Hydrol, in press

Jonckheere I, Fleck S, Nackaerts K, Muys B, Coppin P, Weiss M, Baret F (2004) Review of methods for in situ leaf area index determination Part I. Theories, sensors and hemispherical photography. Agri Forest Meteor 121: 19-35

Kessler M, Keßler PJA, Gradstein SR, Bach K, Schmull M, Pitopang R (2005) Tree diversity in primary forests and different land use systems in Central Sulawesi, Indonesia. Biodiv Conserv 14: 547-560

Kitamura S, Suzuki S, Yumoto T, Chuailua P, Plongmai K, Poonswad P, Noma N, Maruhashi T, Suckasam C (2005) A botanical inventory of a 
tropical seasonal forest in Khao Yai National Park, Thailand: implications for fruit-frugivore interactions. Biodiv Conserv 14: 1241-1262

Koop H, Rijksen HD, Wind J (1995) Tools to diagnose forest integrity: an appraisal method substantiated by Silvi-Star assessment of diversity and forest structure. In: Boyle TJB, Boontawee B (eds) Measuring and Monitoring Biodiversity in Tropical and Temperate Forests. CIFOR, Bogor, Indonesia, pp 309-333

Kramer H, Akça A (2002) Leitfaden zur Waldmeßlehre. Sauerländer Verlag, Frankfurt

Kumagai T, Katul GG, Saitoh TM, Sato Y, Manfroi OJ, Morooka T, Ichie T, Kuraji K, Suzuki M, Porporato A (2004) Water cycling in a Bornean tropical rain forest under current and projected precipitation scenarios. Water Resour Res 40: W01104

Leigh EG (1975) Structure and Climate in Tropical Rain Forest. Ann Rev Ecol Syst 6: 67-86

McElhinny C, Gibbons P, Brack C, Bauhus J (2005) Forest and woodland stand structural complexity: Its definition and measurement. For Ecol Manage 218: 1-24

Migge-Kleian S, Woltmann L, Schaefer M (this volume) Impact of forest disturbance and land use change on soil invertebrate fauna in tropical rainforest margins. In: Tscharntke T, Leuschner C, Guhardja E, Zeller M, Bidin A (eds) The stability of tropical rainforest margins, linking ecological, economic and social constraints of land use and conservation. Springer, Berlin Heidelberg New York

Montgomery RA (2004) Effects of understorey foliage on patterns of light attenuation near the forest floor. Biotropica 36: 33-39

Parton WJ, Haxeltine A, Thornton P, Anne R, Hartman M (1996) Ecosystem sensitivity to land-surface models and leaf area index. Global and Planet Change 13: 89-98

Roberts JM, Gash JHC, Tani M, Bruijnzeel LA (2004) Controls on evaporation in lowland tropical rainforest. In Bonnell M, Bruijnzeel LA (eds) Forests, water and people in the humid tropics. Cambridge University Press, Cambridge, pp 287-313

Ruf F, Schroth G (2004) Chocolate forests and monocultures: A historical review of cocoa growing and its conflicting role in tropical deforestation and forest conservation. In: Schroth G, da Fonseca GAB, Harvey CA, Gascon C, Vasconcelos HL, Izac AMN (eds) Agroforestry and biodiversity conservation in tropical landscapes. Island Press, Washington, pp. 107-134

Schweithelm J (2004) Forest people and changing tropical forestland use in tropical Asia. In Bonnell M, Bruijnzeel LA (eds) Forests, water and people in the humid tropics. Cambridge University Press, Cambridge, pp 66-74

Sri-Gernyuang K, Kanzaki M, Mizuno T, Noguchi H, Teejuntuk S, Sungpalee C, Hara M, Yamakura T, Sahunalu P, Dhanmanonda P, Bunyavejchewin S (2003) Habitat differentiation of Lauraceae species in a tropical lower montane forest in northern Thailand. Ecol Res 18: 1-14 
Takyu M, Aiba SI, Kitayama K (2002) Effects of topography on tropical lower montane forests under different geological conditions on Mount Kinabalu, Borneo. Plant Ecol 159: 35-49

Tobón Marin C, Bouten W, Sevink J (2000) Gross rainfall and its partitioning into throughfall, stemflow and evaporation of intercepted water in four forest ecosystems in western Amazonia. J Hydrol 237: 40-57

Trichton V, Walter JMN, Laumonier Y (1998) Identifying spatial patterns in the tropical rain forest structure using hemispherical photographs. Plant Ecol 137: 227-244

Willott SJ, Lim DC, Compton SG, Sutton SL (2000) Effects of selective logging on the butterflies of a Bornean rainforest. Conserv Biol 14: 1055-1065 


$$
7.2
$$

\section{Rainfall partitioning in relation to stand structure in differently managed montane forest stands in Central Sulawesi, Indonesia}

Johannes Dietz, Dirk Hölscher, Christoph Leuschner, Hendrayanto

In:

Forest Ecology and Management 237 (2006) 170-178 doi:10.1016/ j.foreco.2006.09.044 


\title{
Rainfall partitioning in relation to forest structure in differently managed montane forest stands in Central Sulawesi, Indonesia
}

\author{
Johannes Dietz $^{\mathrm{a}, \mathrm{b}, *}$, Dirk Hölscher ${ }^{\mathrm{a}}$, Christoph Leuschner $^{\mathrm{b}}$, Hendrayanto $^{\mathrm{c}}$ \\ ${ }^{a}$ Tropical Silviculture, Institute of Silviculture, University of Göttingen, Büsgenweg 1, 37077 Göttingen, Germany \\ ${ }^{\mathrm{b}}$ Plant Ecology, Albrecht-von-Haller-Institute for Plant Sciences, University of Göttingen, Untere Karspüle 2, 37073 Göttingen, Germany \\ ${ }^{\mathrm{c}}$ Laboratory of Forest Influences, Institut Pertanian Bogor, Gedung Rektorat lt. 1, Kampus IPB Darmaga, Bogor, Indonesia
}

Received 25 January 2006; received in revised form 6 July 2006; accepted 21 September 2006

\begin{abstract}
Management activities alter the structure of many tropical forest stands which can be expected to influence the magnitude of canopy water fluxes. The objectives of this study were to determine throughfall, stemflow and rainfall interception in differently managed forest stands, and to relate the observed pattern of rainfall partitioning to stand structural characteristics. The study was conducted in a lower montane rainforest region (800-1140 m asl) in Central Sulawesi, Indonesia. Stands of four management types (natural forest, forest subject to small-diameter timber extraction, forest subject to selective logging of large-diameter timber, and cacao agroforest under trees remaining from the natural forest) were analyzed with three replicates per use type. The tree basal area decreased from the natural forest $\left(52.5 \mathrm{~m}^{2} \mathrm{ha}^{-1}\right)$ to the agroforest $\left(19.4 \mathrm{~m}^{2}\right.$ ha $\left.{ }^{-1}\right)$ which was paralleled by a reduction in mean tree height (trees $\geq 10 \mathrm{~cm}$ dbh) from 21.3 to $17.5 \mathrm{~m}$. The estimated leaf area index (LAI), as derived from hemispherical photos, averaged $6.2 \mathrm{~m}^{2} \mathrm{~m}^{-2}$ in the natural forest, 5.3 in forests with small timber extraction, 5.0 in forests with large timber extraction, and 5.3 in the agroforest. The annual gross precipitation close to our different study plots varied locally between 2437 and 3424 mm during the time of the study. Throughfall was measured on 15-17 rain days per plot with a median of 70\% of gross precipitation over all the natural forest plots, 79 and $80 \%$ in forest with small and large timber extraction respectively, and $81 \%$ in the agroforest. Stemflow was less than $1 \%$ in all studied use types. Thus, rainfall interception was highest in the natural forest where $30 \%$ (median) of the gross precipitation was re-evaporated back into the atmosphere, and much lower in the three other use types (18-20\%). Variability in structure and rainfall partitioning was high even within the same forest use types, thus further analysis focused on gradual changes rather than categories. In the 12 stands, LAI alone did not correlate significantly with the pattern of rainfall partitioning, the throughfall percentage increased significantly with decreasing tree height $\left(r^{2}=0.63\right)$. In a multiple linear regression with tree height and LAI as influencing factors, $81 \%$ of the variation in throughfall percentage is explained. A possible reason for this tree height-LAI-throughfall relationship is that under the conditions prevailing in our study region the canopy may not completely dry up between subsequent rainfall events. Therefore, the actual water storage at the start of a rainfall event would be below its potential. We hypothesize that tall trees increase the vertical distribution of foliage and other canopy components contributing to the canopy water storage, resulting in a higher canopy roughness and a more effective energy exchange with the atmosphere. This would consequently lead to an increased re-evaporation of intercepted water, larger available water storage and, thus, a reduced throughfall in stands with tall trees.
\end{abstract}

(C) 2006 Elsevier B.V. All rights reserved.

Keywords: Leaf area index; Logging; Rainfall interception; Stemflow; Throughfall; Tree height

\section{Introduction}

Tropical rain forests are converted to other land cover types at a high rate and Southeast Asia experienced especially rapid

\footnotetext{
* Corresponding author at: Tropical Silviculture, Institute of Silviculture, University of Göttingen, Büsgenweg 1, 37077 Göttingen, Germany. Tel.: +49 551 399556; fax: +49 551394019 .

E-mail address: dietz.johannes@gmail.com (J. Dietz).
}

deforestation over the last years (Archard et al., 2002; FAO, 2001). There is increasing awareness that, in addition to conversion, large forest areas are encroached by selective logging. For five states of the Brazilian Amazon, the analysis of selective logging doubled previous estimates of the total annual extent of forest degraded by human activities (Asner et al., 2005). The effects of forest conversion to, e.g., pasture land have been intensively studied. These investigations revealed severe changes in the hydrological cycle (Hodnett et al., 1995; Grip et al., 2004). Changes in the amount of water intercepted 
by and re-evaporated from vegetation surfaces was one of the most essential alterations in hydrological fluxes resulting from forest conversion. Less information is available for more gradual changes in vegetation structure as created by different logging practices.

The studies on the effect of logging on rainfall partitioning so far yielded contrasting results. In a lowland dipterocarp forest on Borneo, Central Kalimantan, Indonesia, the rainfall interception was $11 \%$ of gross precipitation $(\mathrm{Pg})$ in an unlogged natural forest and 6\% of $\mathrm{Pg}$ in a logged forest (Asdak et al., 1998) which thus points to a decrease in interception with disturbance. However, in another lowland dipterocarp forest in northern Borneo, Sabah, Malaysia, it was found that $91 \%$ of $\mathrm{Pg}$ reached the ground as throughfall in an unlogged natural forest, whereas 80 and $84 \%$ of throughfall were recorded in plots of moderately and highly damaged patches of forest (Chappell et al., 2001). Assuming stemflow to be $1 \%$ of above-canopy rainfall (Chappell et al., 2001 ), interception in these stands can be estimated with $8 \%$ of $\mathrm{Pg}$ in the undisturbed forest and with 15 and $19 \%$ of $\mathrm{Pg}$ in the two logged forests, indicating interception rates to increase with disturbance intensity (Chappell et al., 2001). With both studies from lowland dipterocarp forests pointing to contrasting effects of logging on rainfall partitioning, there is clearly need for further investigation.

Canopy water fluxes such as interception and throughfall are primarily dependent on climate factors and vegetation structure (Crockford and Richardson, 2000). Canopy cover, leaf area and, more controversially discussed, bark structure are thought to be key factors for the canopy water storage capacity and thus may affect rainfall interception (Herwitz, 1985; Gash et al., 1995; van Dijk and Bruijnzeel, 2001). Another factor is tree height and associated canopy roughness length that may influence the exchange of water and energy with the atmosphere (e.g. Asdak et al., 1998; Chappell et al., 2001; Hölscher et al., 2004). Stem density and crown structure may be important for stemflow generation (Hölscher et al., 2005). However, it is still difficult to assess the relative importance of these stand attributes for water turnover in the canopy. If a single stand characteristic is analyzed separately, some studies yielded unexpected results. For example, analyzing the contribution of epiphyte vegetation to interception in montane neotropical stands, two independent studies suggested that epiphytes may have little influence (Hölscher et al., 2004; Fleischbein et al., 2005). Relationships between stand structure and rainfall partitioning may sometimes be obscured by an insufficient number of study plots. In previous studies, much attention has been paid to appropriate sampling schemes within a stand (e.g. Lloyd et al., 1988; Holwerda et al., 2006). However, gradients of changing forest structure or more than one plot per forest type have rarely been studied so far.

The present study was conducted in a montane rain forest region of Central Sulawesi, Indonesia, where forest stands are differently managed by members of the local community (Helmi, 2005). In four types of forest along a gradient of forest use intensity three replicate plots per use type were analyzed. We revisited the assumption that rainfall partitioning into stemflow, throughfall and interception may change with forest use intensity and can be linked to stand structural characteristics, also independently from management practices which were defined by local traditions. Therefore, the aims of the study were: (i) to conduct a comparative analysis of stand structural characteristics presumed to be important for rainfall partitioning (such as leaf area index (LAI), stem density, basal area and tree height), (ii) to determine rainfall partitioning, and (iii) to single out stand characteristics that may control the partitioning by regression analyses.

\section{Methods}

\subsection{Study sites}

The study was conducted in the margin zone of the Lore Lindu National Park in Central Sulawesi, Indonesia. The study plots were located at lower montane elevations (800$1140 \mathrm{~m}$ asl $)$ in the vicinity of the village of Toro $\left(1.5014^{\circ} \mathrm{S}\right.$, $120.0355^{\circ} \mathrm{E}$ ). In accordance with traditional local management as put forward by the head of the village and endorsed by the head of the National Park authority (Helmi, 2005), we selected four forest use types. These were: (a) natural forest, (b) forest with extraction of small-diameter timbers (hereafter termed 'small timber extraction'), (c) forest with selective extraction of large timbers (hereafter termed 'large timber extraction'), and (d) cacao (Theobroma cacao) plantations under trees remaining from the natural forest (agroforest). We studied three replicates per use type. The natural forest was usually more distant to the Toro settlement (mean distance $1.8 \mathrm{~km}$ ), than the more intensively used agroforest plots $(0.8 \mathrm{~km}$, Fig. 1$)$. On the 12 plots, the slopes ranged between $17^{\circ}$ and $39^{\circ}$ and all expositions were represented (Table 1). In the natural forest, up to 63 tree species $(\geq 10 \mathrm{~cm}$ dbh per $0.25 \mathrm{ha}$ ) were found with Meliaceae, Lauraceae, Sapotaceae, and Fagaceae having the highest share. The tree species richness was little affected by small timber extraction, but was lower in stands after large timber extraction (53 species per $0.25 \mathrm{ha}$ ) and lowest in the agroforest ( 32 species per 0.25 ha). The composition of tree species changed with use type and the proportion of endemics decreased towards the agroforest (Gradstein et al., in press).

In the study period, the annual mean temperature measured at an automatic weather station on the bottom of the Toro Valley was $23.1^{\circ} \mathrm{C}$ and the annual rainfall total was $1812 \mathrm{~mm}$ (Kreilein et al., unpublished). At this station, the average rainfall intensity was relatively low $\left(3.4 \mathrm{~mm} \mathrm{~h}^{-1}\right.$, Table 2$)$. As the valley bottom, where the automatic weather station was positioned, appeared to receive less precipitation than the surrounding slopes, we additionally deployed four manually gauged stations close to our study sites. There, the annual precipitation ranged from 2437 to $3424 \mathrm{~mm}$. Toro is situated at a narrow part of Sulawesi and the open sea is within approximately $75 \mathrm{~km}$ to the east and west.

\subsection{Stand characteristics}

For all trees with a diameter at breast height $(\mathrm{dbh})$ of $10 \mathrm{~cm}$ or more, dbh and height were measured on $1500 \mathrm{~m}^{2}$ plots. To 

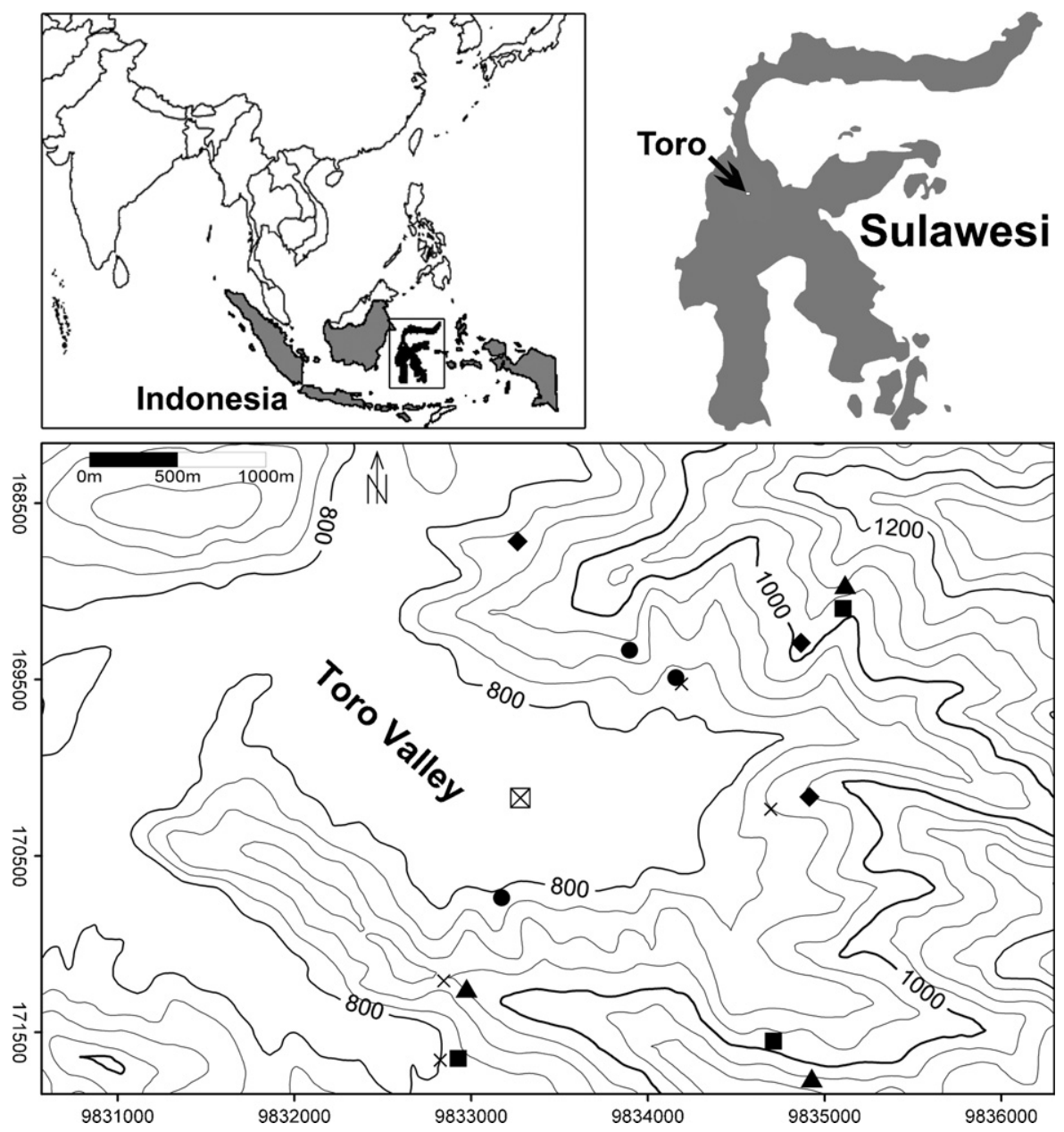

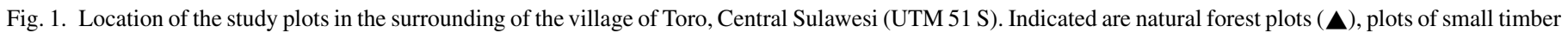

account for smaller statured trees, all individuals with $\mathrm{dbh}<10 \mathrm{~cm}$, but higher than $2 \mathrm{~m}$, were assessed on three randomly located subplots of $5 \mathrm{~m} \times 5 \mathrm{~m}$ within the study plots. In the agroforest stands, all stems taller than $2 \mathrm{~m}$ were assessed. The dbh was measured with a tape and heights were taken with an ultrasonic hypsometer (Vertex III, Haglöf, Långsele, Sweden). The presented results are corrected for slope.
Hemispherical photographs were taken vertically upward with a digital camera mounted on a leveling device (HemiView, Delta-T, Cambridge, UK). In each plot, photos were taken at three dates, on 30 randomly located points per plot and at a height of $1.5 \mathrm{~m}$ above the ground. The images were analyzed for canopy openness (WinScanopy, 2004a; Régent Instruments Inc., Sainte-Foy, Canada; opening angle of $30^{\circ}$ ) and leaf area

Table 1

Geographical position and site characteristics of the study plots

\begin{tabular}{|c|c|c|c|c|c|c|}
\hline Forest use type & Abbr. & UTM X 51S (m) & UTM Y 51S (m) & Elevation (m asl) & Exposition & Inclination $\left({ }^{\circ}\right)$ \\
\hline Natural forest 1 & NF 1 & 171250 & 9832974 & 948 & SSE & 32.2 \\
\hline Natural forest 4 & NF 4 & 171759 & 9834927 & 1042 & WNW & 20.9 \\
\hline Natural forest 5 & NF 5 & 168961 & 9835116 & 1130 & NE & 17.0 \\
\hline Small timber extraction 2 & STE 2 & 171648 & 9832926 & 873 & SSE & 37.6 \\
\hline Small timber extraction 3 & STE 3 & 169097 & 9835104 & 1078 & NNE & 31.2 \\
\hline Small timber extraction 4 & STE 4 & 171550 & 9834710 & 982 & $\mathrm{~W}$ & 33.2 \\
\hline Large timber extraction 1 & LTE 1 & 169292 & 9834866 & 974 & SSW & 25.0 \\
\hline Large timber extraction 3 & LTE 3 & 168716 & 9833262 & 827 & $\mathrm{~W}$ & 35.0 \\
\hline Large timber extraction 4 & LTE 4 & 170165 & 9834914 & 959 & ESE & 30.2 \\
\hline Agroforest 2 & AF 2 & 169333 & 9833896 & 952 & $\mathrm{E}$ & 20.6 \\
\hline Agroforest 3 & AF 3 & 169489 & 9834158 & 832 & NNW & 38.9 \\
\hline Agroforest 4 & AF 4 & 170737 & 9833172 & 806 & SSW & 37.1 \\
\hline
\end{tabular}


Table 2

Rainfall characteristics during the study period (April 5, 2004 to April 4, 2005) at the valley bottom close to the village of Toro $(790 \mathrm{~m}$ asl; Kreilein et al., unpublished data)

\begin{tabular}{ll}
\hline Number of days observed & 366 \\
Number of days, $\mathrm{Pg}>0.2 \mathrm{~mm}$ & $218(60 \%)$ \\
Number of rain storms & 526 \\
Number of rain storms $>0.2 \mathrm{~mm}$ & $282(54 \%)$ \\
Gross precipitation, $\mathrm{Pg}(\mathrm{mm})$ & 1828 \\
Average rain storm size $(\mathrm{mm})$ & 6.5 \\
Average rain storm duration $(\mathrm{h})$ & 1.9 \\
Average rainfall intensity, $\bar{R}\left(\mathrm{~mm} \mathrm{~h}^{-1}\right)$ & 3.4 \\
\hline
\end{tabular}

Individual rainstorms were defined as precipitation events of more than the minimum resolution of the tipping bucket rain gauge (i.e. $>0.2 \mathrm{~mm}$ ) and delimited from the following rainstorm by a dry period of at least $2 \mathrm{~h}$.

index (CanEye V 3.6, INRA, Avignon, France). We did not observe a seasonal pattern in either parameter (Dietz et al., in press-a) and thus based the following analyses on data obtained during a single measurement campaign (April 2005).

\subsection{Gross rainfall, throughfall, and stemflow}

Incident rainfall was measured adjacent to each of the 12 study plots with five bulk samplers per location. The localities for the measurements of gross precipitation were within a $150 \mathrm{~m}$ range from the study plots, situated at the same altitude and had the same aspect. The gauges were placed at a height of $100 \mathrm{~cm}$ in open area where trees or other taller objects were more than $35 \mathrm{~m}$ away. In other cases, where the openings were smaller, the bulk samplers were placed on 5 or $7 \mathrm{~m}$ tall bamboo structures. The collectors had an orifice of $295 \mathrm{~cm}^{2}$ each and a vertical rim $3.5 \mathrm{~cm}$ high. A table tennis ball was placed in each of the funnels to reduce evaporation from the gauges. During measurement campaigns in the adjacent forest plots the rainfall volumes were measured daily.

Daily measurements of throughfall and stemflow were conducted in each of the study plots during campaigns for periods of about 24 days to record 15-17 days with detectable incident rainfall which coincides with measuring periods by Manfroi et al. (2006). These campaigns were conducted between June 2004 and March 2005. Throughfall was collected with 30 funnels per plot that were built identically to the rain gauges described above. They were installed at $100 \mathrm{~cm}$ above the ground. The throughfall collectors were arranged along three lines of each $50 \mathrm{~m}$ length, parallel to the contour with $10 \mathrm{~m}$ distance between the lines. On these lines the collector positions were defined by random with a minimum distance of $2 \mathrm{~m}$ between two samplers.

Stemflow was measured using spiral collars attached to 10 stems $(\geq 10 \mathrm{~cm}$ in dbh) in each of the plots. Five of these trees reached the upper tree layer while the remaining trees were smaller. The trees of the upper tree layer were on average $29 \mathrm{~m}$ tall with a mean dbh of $45 \mathrm{~cm}$ while the sub-canopy trees were on average $22 \mathrm{~m}$ tall with a mean dbh of $15 \mathrm{~cm}$. Stemflow volumes per unit ground area for the $1500 \mathrm{~m}^{2}$ plots were estimated from linear regressions (intercept $=0$ ) between $\mathrm{dbh}$ and the stemflow volume per volume gross precipitation. These

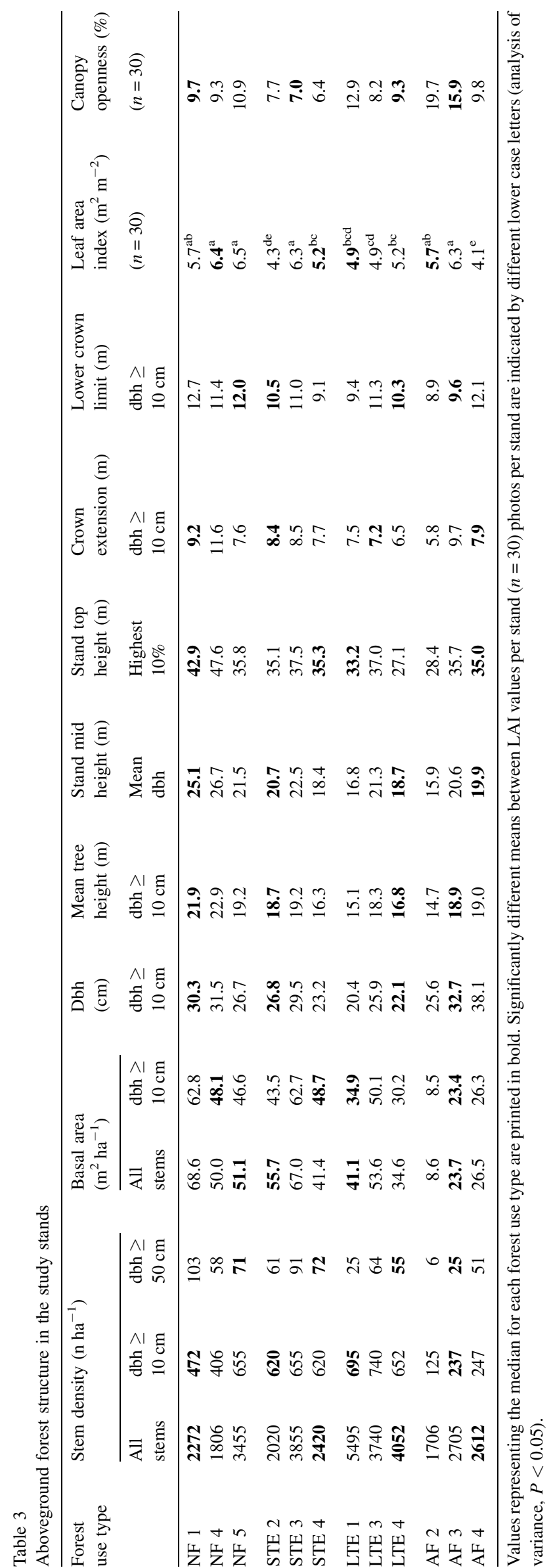


regressions were established from trees of the three plots belonging to the same forest use type (usually $n=30$ stemflow collectors per use type). The volume of stemflow significantly increased with dbh and the determinants of variation $\left(r^{2}\right)$ were 0.52 in the natural forest, 0.53 after small timber extraction, 0.34 after large timber extraction, and 0.30 in the agroforest. For trees $<10 \mathrm{~cm}$ dbh the regression lines were extrapolated and the stemflow volume per plot area was calculated on the basis of measured dbh and stem density. Because the sugar palm Arenga pinnata exceeded the stemflow yield of dicotyledonous trees considerably, these three palms (one individual each in STE2, STE4, and AF3; see Table 4) were always measured and not included into the regression analysis. Rather, their empirically determined stemflow volumes were included directly into the calculations where such palm was present in the research plot.

\subsection{Statistical analysis}

Multiple comparisons among group means for LAI were conducted with an analysis of variance (Duncan's test); for throughfall the non-parametric Wilcoxon rank sum test (twotailed) was applied. The relationships between rainfall partitioning and stand structural characteristics were analyzed using Spearman's rank correlation and where applicable also simple and multiple linear regression models were used. The standard level of significance was $P \leq 0.05$. The statistical analyses were conducted with SAS software (SAS Institute Inc., Cary, NC, US; Version 8.2).

\section{Results}

\subsection{Aboveground stand structure}

The median basal area of trees $\geq 10 \mathrm{~cm}$ dbh decreased from $51 \mathrm{~m}^{2} \mathrm{ha}^{-1}$ in the natural forest to $24 \mathrm{~m}^{2} \mathrm{ha}^{-1}$ in the agroforest (Table 3 ). This was paralleled by a reduction in tree height. The mean height of trees $\geq 10 \mathrm{~cm}$ dbh decreased from 22 to $17 \mathrm{~m}$, and the top height (height of the $10 \%$ thickest trees $\geq 10 \mathrm{~cm}$ dbh) dropped from 43 to $33 \mathrm{~m}$. The density of small stems was highest after large timber extraction (4052 stems per ha) and was relatively similar in the other forest use types (between 2272 and 2612 stems per ha). The average canopy openness, as determined from photographs taken at $1.5 \mathrm{~m}$ above the ground, was $10-11 \%$ per site in the natural forest and highest in cacao agroforest (between 10 and 20\% in the three plots). Among stands of the same forest use type, the average LAI per plot showed a considerable variation. In the 12 plots, it ranged in from $6.5 \mathrm{~m}^{2} \mathrm{~m}^{-2}$ in a natural forest stand to $4.1 \mathrm{in}$ an agroforest plot (Table 3).

\subsection{Throughfall, stemflow, and interception}

During the measurement campaigns which comprised of 1517 rain days each, a mean gross precipitation of $228 \mathrm{~mm}$ was observed $(148-480 \mathrm{~mm})$. In the four forest use types, the median of throughfall was lowest in natural forest $(70 \%$ of $\mathrm{Pg})$, and similarly high in all other use types (79-81\%; Table 4). Among plots of the same type, the lowest variation in throughfall percentage was observed after large timber extraction (coefficient of variation 4\%) and the highest in the natural forest (cv. 27\%). Stemflow, including the exceptionally high input by sugar palms, was estimated with less than $1 \%$ of $\mathrm{Pg}$ in all studied use types. In our estimate, approximately $40 \%$ of all stemflow was contributed by stems smaller than $10 \mathrm{~cm}$ in diameter. The sugar palm A. pinnata had three-fold higher stemflow values than dicotyledonous trees of the same size, but only three individuals of these trees were encountered (one individual each in STE2, STE4, and AF3; see Table 4). The calculated rainfall interception in the 12 plots ranged from virtually none $(-1 \%$ of $\mathrm{Pg})$ in an agroforest to $53 \%$ in a natural forest. Interception was highest in the natural forest where as the median $30 \%$ of $\mathrm{Pg}$ were re-evaporated back into the atmosphere, and much less in the three other use types (18-20\% of $\mathrm{Pg}$ ).

Table 4

Rainfall partitioning in the 12 study plots

\begin{tabular}{|c|c|c|c|c|c|c|c|c|c|}
\hline & \multirow{2}{*}{$\begin{array}{l}\text { Number of } \\
\text { rainy days }\end{array}$} & \multirow{2}{*}{$\begin{array}{l}\text { Gross } \\
\text { precipitation }(\mathrm{mm})\end{array}$} & \multicolumn{3}{|c|}{ Throughfall $^{\mathrm{a}}(\%$ of $\mathrm{Pg}$ ) } & \multicolumn{3}{|l|}{ Stemflow } & \multirow{2}{*}{$\begin{array}{l}\text { Interception } \\
(\% \text { of } \mathrm{Pg})\end{array}$} \\
\hline & & & 25 th & Median & 75 th & $(\%$ of $\mathrm{Pg})$ & $\frac{\mathrm{dbh} \geq 10 \mathrm{~cm}}{\mathrm{dbh}<10 \mathrm{~cm}}$ & Input by palms (\%) & \\
\hline NF 1 & 18 & 215 & 37.3 & $46.6^{\mathrm{d}}$ & 55.3 & 0.6 & 1.4 & 0.0 & 52.8 \\
\hline NF 4 & 17 & 165 & 52.2 & $69.8^{\mathrm{c}}$ & 79.0 & 0.3 & 2.2 & 0.0 & 29.9 \\
\hline NF 5 & 17 & 148 & 71.8 & $81.9^{\mathrm{b}}$ & 95.6 & 0.5 & 1.6 & 0.0 & 17.6 \\
\hline STE 2 & 16 & 480 & 53.5 & $70.7^{\mathrm{c}}$ & 82.8 & 0.7 & 1.8 & 2.4 & 28.6 \\
\hline STE 3 & 16 & 315 & 68.1 & $79.1^{\mathrm{ab}}$ & 101.8 & 0.9 & 1.9 & 0.0 & 20.0 \\
\hline STE 4 & 16 & 300 & 80.9 & $92.5^{\mathrm{a}}$ & 97.0 & 0.6 & 2.7 & 13.8 & 6.9 \\
\hline LTE 1 & 15 & 220 & 59.1 & $86.7^{\mathrm{ab}}$ & 107.3 & 0.7 & 0.9 & 0.0 & 12.6 \\
\hline LTE 3 & 15 & 185 & 67.4 & $80.2^{\mathrm{b}}$ & 94.3 & 0.7 & 2.1 & 0.0 & 19.1 \\
\hline LTE 4 & 15 & 259 & 67.8 & $80.3^{\mathrm{ab}}$ & 108.5 & 0.6 & 1.2 & 0.0 & 19.0 \\
\hline AF 2 & 18 & 293 & 79.0 & $100.5^{\mathrm{a}}$ & 111.1 & 0.7 & 0.8 & 0.0 & -1.2 \\
\hline AF 3 & 17 & 172 & 68.7 & $81.2^{\mathrm{b}}$ & 100.2 & 0.9 & 1.0 & 19.0 & 17.9 \\
\hline $\mathrm{AF} 4$ & 18 & 214 & 48.2 & $64.2^{c}$ & 86.2 & 1.0 & 1.0 & 0.0 & 34.8 \\
\hline
\end{tabular}

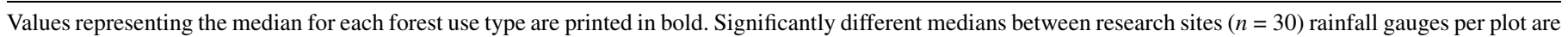
indicated by different lower case letters (Wilcoxon signed ranks test, two-tailed, $P<0.05$ ).

a Shown are the 25th, 50th (median), and 75th percentiles. 
Table 5

Spearman's rank correlation coefficients (two-tailed) between rainfall partition components and stand structural characteristics for the 12 study plots

\begin{tabular}{|c|c|c|c|c|}
\hline & \multicolumn{3}{|c|}{ Throughfall (\% of Pg) } & \multirow{2}{*}{$\begin{array}{l}\text { Interception }(\% \text { of } \mathrm{Pg}) \\
\text { All days }\end{array}$} \\
\hline & $\mathrm{Pg} \leq 10 \mathrm{~mm} \mathrm{~d}^{-1}$ & $\mathrm{Pg}>10 \mathrm{~mm} \mathrm{~d}^{-1}$ & $\overline{\text { All days }}$ & \\
\hline Elevation (m asl) & -0.02 & 0.40 & 0.32 & -0.32 \\
\hline Exposition $\left({ }^{\circ}\right)$ & -0.13 & -0.13 & -0.03 & 0.03 \\
\hline Inclination $\left(^{\circ}\right)$ & 0.19 & -0.50 & -0.36 & 0.36 \\
\hline \multicolumn{5}{|l|}{ Stem density } \\
\hline All stems $\left(\mathrm{n} \mathrm{ha}^{-1}\right)$ & 0.13 & 0.24 & 0.16 & -0.16 \\
\hline $\mathrm{dbh} \geq 10 \mathrm{~cm}\left(\mathrm{n} \mathrm{ha}^{-1}\right)$ & -0.12 & 0.23 & 0.09 & -0.09 \\
\hline $\mathrm{dbh} \geq 50 \mathrm{~cm}\left(\mathrm{n} \mathrm{ha}^{-1}\right)$ & -0.39 & -0.31 & -0.39 & 0.39 \\
\hline \multicolumn{5}{|l|}{ Basal area } \\
\hline All stems $\left(\mathrm{m}^{2} \mathrm{ha}^{-1}\right)$ & -0.42 & -0.45 & -0.52 & 0.52 \\
\hline $\mathrm{dbh} \geq 10 \mathrm{~cm}\left(\mathrm{~m}^{2} \mathrm{ha}^{-1}\right)$ & -0.56 & -0.28 & -0.41 & 0.41 \\
\hline $\operatorname{Dbh}(\mathrm{dbh} \geq 10 \mathrm{~cm})(\mathrm{cm})$ & -0.36 & $-0.83^{* * *}$ & $-0.69^{*}$ & $0.60^{*}$ \\
\hline Mean tree height $(\mathrm{dbh} \geq 10 \mathrm{~cm})(\mathrm{m})$ & $-0.58^{*}$ & $-0.76^{* *}$ & $-0.74^{* *}$ & $0.74^{* *}$ \\
\hline Stand mid height (mean dbh) (m) & $-0.58^{*}$ & $-0.69^{*}$ & $-0.71^{* *}$ & $0.71^{* *}$ \\
\hline Stand top height (highest $10 \%$ ) (m) & $-0.69^{*}$ & -0.52 & -0.51 & 0.51 \\
\hline Crown extension $(\mathrm{m})$ & -0.32 & $-0.73^{* *}$ & $-0.61^{*}$ & $0.61^{*}$ \\
\hline Low crown limit (m) & $-0.71^{*}$ & $-\mathbf{0 . 7 8}$ * $^{* *}$ & $-0.83^{* * * *}$ & $0.83^{* * *}$ \\
\hline Leaf area index $\left(\mathrm{m}^{2} \mathrm{~m}^{-2}\right)$ & -0.15 & 0.09 & 0.14 & -0.14 \\
\hline Canopy openness (\%) & -0.01 & 0.13 & 0.29 & -0.29 \\
\hline
\end{tabular}

Significant correlations $(P<0.05)$ are highlighted in bold.

* $P<0.05$.

** $P<0.01$

**** $P<0.001$

\subsection{The relationship between stand structure and rainfall partitioning}

Based on Spearman's rank correlations it became evident that there were no significant correlations between topographical parameters and rainfall partitioning for all 12 study plots (Table 5). The mean $\mathrm{dbh}$ of stems $\geq 10 \mathrm{~cm}$ dbh correlated significantly with the throughfall percentage (Spearman's rho $=-0.69$, Table 5). With increasing dbh the throughfall percentage decreased. The correlation consolidated when only days of strong precipitation $(\geq 10 \mathrm{~mm}$ of $\mathrm{Pg}$ ) are considered. Strong correlations were obtained between throughfall and all

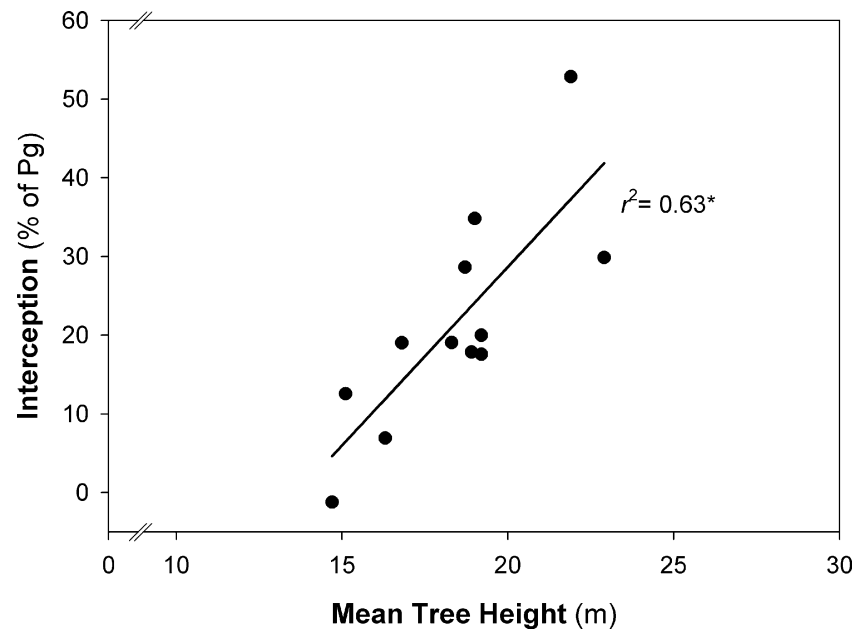

Fig. 2. Rainfall interception as a function of mean tree height $(\mathrm{dbh} \geq 10 \mathrm{~cm})$ in the 12 study plots. parameters of tree height. The throughfall percentage increased significantly with decreasing tree height. Mean tree height $(\geq 10 \mathrm{~cm} \mathrm{dbh}$ ) yielded a Spearman's rho of -0.74 and stand mid height of -0.71 . Crown extension was only significantly correlated to throughfall percentage when days with rainfall of more than $10 \mathrm{~mm}$ are included. The strongest correlation was observed between the lower crown limit (lowest point of ramification) and throughfall (Spearman's rho $=-0.83$ ). Mean LAI and mean canopy openness alone were not significantly correlated with the median of throughfall percentage. However, a multiple linear regression with mean tree height $(\geq 10 \mathrm{~cm}$ $\mathrm{dbh}$ ) and mean LAI as parameters explained $81 \%$ of the variation observed in mean throughfall. As stemflow did not differ much among the study plots, the results on throughfall also apply to interception, which must also be closely correlated to tree height (Table 5 and Fig. 2).

\section{Discussion}

\subsection{Stand structural characteristics}

The basal area in the studied natural forest (median $51 \mathrm{~m}^{2} \mathrm{ha}^{-1}$ ) is higher than in most lowland forests studied by other authors. However, when compared to other natural forests above $600 \mathrm{~m}$ in elevation in the Southeast Asian region it is well within the reported range (Aiba and Kitayama, 2002; Brodbeck, 2004; Hamann et al., 1999; Kessler et al., 2005; Kitamura et al., 2005; Sri-Gernyuang et al., 2003). The stand basal area in our study region is sensitive to the forest use practice and was reduced by large timber extraction $\left(41 \mathrm{~m}^{2} \mathrm{ha}^{-1}\right)$, or by conversion to agroforest $\left(24 \mathrm{~m}^{2} \mathrm{ha}^{-1}\right)$. 
As big and tall trees were harvested, tree height also decreased after large timber extraction. In Sulawesi, the average LAI of the natural forest plots ranged between 5.7 and 6.5 , with a median at $6.4 \mathrm{~m}^{2} \mathrm{~m}^{-2}$ in this forest type. For natural forest in Amazonia, values between 3.6 and 6.6 were reported (Aragão et al., 2005), in Sumatra, Indonesia, between 3.9 and 6.1 (Trichton et al., 1998), and in Borneo, Malaysia between 4.8 and 6.8 (Kumagai et al., 2004). In a pan-tropical review, Roberts et al. (2004) collected LAI values ranging between 4.1 and 8.0 for lowland rainforests with a tendency of higher values in Asia. Thus, the values obtained on our study plots are well within the range of other studies. In Sulawesi, the LAI had reached its median at 5.2 in forest plots with small timber extraction, at 4.9 in forests with large timber extraction and at 5.7 in the agroforest. These data point to a relative quick recovery of LAI after disturbance. The relatively high LAI values in managed stands also compare well with results from Amazonia where only little differences in LAI between natural forests and selectively logged sites were observed (Aragão et al., 2005). The structure of individual plots within a forest use type varied and not always produced significant differences between those management types. However, the impact of management on the forest structure became evident, especially when comparing the managed to the natural forest plots.

\subsection{Throughfall, stemflow, and interception}

The annual gross precipitation $(\mathrm{Pg})$ close to four of our study plots ranged between 2437 and $3424 \mathrm{~mm}$. In the study plots we measured throughfall and stemflow for periods of 15-17 rainy days (see also Manfroi et al., 2006). In the natural forest, throughfall reached its median at $70 \%$ of $\mathrm{Pg}$, stemflow was less than $1 \%$ and interception $30 \%$. A similarly low stemflow fraction has also been observed in most tall old-growth forests, both in montane (Steinhardt, 1979) and lowland settings (Lloyd et al., 1988; Ubarana, 1996; Tobón Marin et al., 2000). Our value is slightly less than that observed in a lowland forest in Sarawak where stemflow was estimated at 3\% of Pg (Manfroi et al., 2004) which may be due to the better representation of small statured trees in that stand. The observation, that palms (such as A. pinnata in our study) may have higher stemflow values than co-occurring trees has also been reported from other forest stands (e.g. Jordan and Heuveldop, 1981; Lloyd et al., 1988). Rainfall interception in the lower montane forest of Sulawesi is within the range observed for other montane forests not subject to substantial cloud incidence (20-37\% of $\mathrm{Pg}$; Bruijnzeel and Proctor, 1995; Bruijnzeel, 2001) as only very infrequent days of fog were observed in the Toro Valley, but the measured interception is higher than in lowland forests. In Southeast Asian lowland forests, high interception rates were reported for stands in Brunei and Sarawak close to the South China Sea (Dykes, 1997; Kumagai et al., 2005) and the prevailing maritime climate with a possible advection of energy may have contributed to this result.

In the forest plots under management, the rainfall interception was lower than in the natural forest (18-20\% versus $30 \%$ of $\mathrm{Pg}$ ). In one of the agroforestry stands, we even found a higher sum of stemflow and throughfall than the measured $\mathrm{Pg}$ (interception of $-1 \%$ ). As our measurement scheme for throughfall and stemflow seems quite robust, a likely source of error is the less reliable measurement of gross precipitation which is a problem in many studies (Crockford and Richardson, 2000). For example, wind driven rain and contrasting atmospheric turbulence patterns above the stand and above the clearing may have caused a bias in the Pg data. As mentioned above, fog was rarely observed to form on the lower slopes around the Toro Valley where the study plots where located (personal observation). Thus, it is unlikely that intercepted fog may have contributed to exaggerated throughfall volumes on the study sites in question. In our study, we could not distinguish sources of error and thus opted to maintain the full observed data variability of results in the further analyses. On this basis, our data suggest that rainfall interception was reduced by logging from 30 to $18 \%$ of $\mathrm{Pg}$. This shift confirms earlier results in a lowland forest in Kalimantan, where the rainfall interception was $11 \%$ in a natural forest and $6 \%$ in a logged forest (Asdak et al., 1998). On the other hand, our data seem to conflict with observations from Sabah, where interception was estimated with $8 \%$ of $\mathrm{Pg}$ in an undisturbed forest and with 15 and $19 \%$ of Pg in a logged forest (Chappell et al., 2001). In both studies, alterations in tree height and associated canopy roughness lengths by logging were seen as the major cause of the change in rainfall partitioning. Canopy roughness may influence the exchange of water and energy with the atmosphere and may lead to enhanced interception (Asdak et al., 1998) but can probably also increase the net rainfall volume (Chappell et al., 2001). Considering the existing studies it thus appears difficult to draw general conclusions on the effects of logging on rainfall partitioning.

\subsection{The relationship between stand structural characteristics and rainfall partitioning}

In our study, LAI alone did not correlate with throughfall. In contrast, stem density and especially tree height characteristics (mean height, mid height, top height, lower crown limit) were closely correlated to throughfall. A high $r^{2}(0.81)$ was also obtained from a multiple linear regression with mean tree height and LAI as parameters. An explanation could be that the potential canopy water storage, to which leaf area contributes significantly, is not available at every rainfall event. For an other natural forest stand in Central Sulawesi, it was shown that during rainy periods of several weeks the canopy surfaces remained wet for more than $50 \%$ of the time (Dietz et al., in press-b). Thus, besides the size of the canopy water storage, its actual availability, which may be controlled by evaporation processes, is important as well. Taller trees are commonly associated with a greater roughness length of the stand which therefore receive a more effective turbulent energy exchange with the atmosphere (e.g. Kelliher et al., 1993). As a consequence, the canopy would dry up more often between rainfall events in tall stands and would remain wet for longer periods of time in stands with lower-statured trees and a more clumped distribution of the foliage. A result pointing in the 
same direction was found in a montane forest of Costa Rica, where young secondary and old-growth forests differed greatly in rainfall interception but not in LAI, and the higher epiphyte abundance in the old-growth stand could not explain the observed differences (Hölscher et al., 2004; Köhler et al., 2006). The authors similarly suggested that a more effective energy exchange in the taller old-growth forest might have caused these patterns. The canopy roughness may also be of great importance for differences in rainfall interception between logged and unlogged forest (Asdak et al., 1998; Chappell et al., 2001). In Central Kalimantan, Asdak et al. (1998) found that logging reduced the rainfall interception and discussed the reduced roughness of logged stands as a probable cause. On the other hand, Chappell et al. (2001) found an increase in interception after logging and suggested that a higher roughness length may increase the energy exchange with the atmosphere leading to higher evaporation rates, while tall trees would also enhance the capture of falling rain drops from turbulent eddies and thus experience a higher precipitation than smaller trees. However, in our study region in Sulawesi, the effect of canopy roughness on evaporation (cf. Asdak et al., 1998) seems to be more important than any positive effect by large trees on precipitation (cf. Chappell et al., 2001). Thus, our results support the view by Asdak et al. (1998) that logging reduces the tree height, which may affect surface roughness, and consequently reduces the rainfall interception in tropical moist forests.

\section{Acknowledgement}

This study was conducted in the framework of the joint Indonesian-German research project 'Stability of Tropical Rainforest Margins, Indonesia (STORMA)' funded by the German Science Foundation (SFB 552, sub-project B4).

\section{References}

Aiba, S.I., Kitayama, K., 2002. Effects of the 1997-98 El Niño drought on rain forests of Mount Kinabalu, Borneo. J. Trop. Ecol. 18, 215-230.

Aragão, L.E.O.C., Shimabukuro, Y.E., Espírito Santo, F.D.B., Williams, M., 2005. Landscape pattern and spatial variability of leaf area index in Eastern Amazonia. For. Ecol. Manage. 211, 240-256.

Archard, F., Eva, H.D., Stibig, H.J., Mayaoux, P., Gallego, J., Richards, T., Malingreau, J.P., 2002. Determination of deforestation rates of the world's humid tropical forests. Science 297, 999-1002.

Asdak, C., Jarvis, P.G., van Gardingen, P., Fraser, A., 1998. Rainfall interception loss in unlogged and logged forest areas of Central Kalimantan, Indonesia. J. Hydrol. 206, 237-244.

Asner, G.P., Knapp, D.E., Broadbent, E.N., Oliveira, P.J.C., Keller, M., Silva, J.N., 2005. Selective logging in the Brazilian Amazon. Science 310, 480482.

Brodbeck, F., 2004. Structure and Processes in Traditional Forest Gardens of Central Sulawesi, Indonesia. Cuvillier Verlag, Göttingen.

Bruijnzeel, L.A., 2001. Hydrology of tropical montane cloud forests: a reassessment. Land Use Water Resour. Res. 1, 1.1-1.18.

Bruijnzeel, L.A., Proctor, J., 1995. Hydrology and biochemistry of tropical montane cloud forests: what do we really know? In: Hamilton, L.S., Juvik, J.O., Scatena, F.N. (Eds.), Tropical Montane Cloud Forests, Ecological Studies 110. Springer, Berlin, pp. 38-78.
Chappell, N.A., Bidin, K., Tych, W., 2001. Modelling rainfall and canopy controls on net-precipitation beneath selectively-logged tropical forest. Plant Ecol. 153, 215-229.

Crockford, R.H., Richardson, D.P., 2000. Partitioning of rainfall into throughfall, stemflow and interception: effect of forest type, ground cover and climate. Hydrol. Process. 14, 2903-2920.

Dietz, J., Hölscher, D., Leuschner, Ch., Malik, A., Amir, M.A. Forest structure as influenced by different types of community forestry in a lower montane rainforest of Central Sulawesi, Indonesia. In: Tscharntke, T., Leuschner, Ch., Guhardja, E., Zeller, M. (Eds.), The Stability of Tropical Rainforest Margins: Linking Ecological, Economic and Social Constraints of Land Use and Conservation. Springer, Berlin, Heidelberg, New York, in press-a.

Dietz, J., Leuschner, Ch., Hölscher, D., Kreilein, H. Vertical patterns and duration of surface wetness in an old-growth tropical montane rainforest, Indonesia. Flora, in press-b.

Dykes, A.P., 1997. Rainfall interception from a lowland tropical rainforest in Brunei. J. Hydrol. 200, 260-279.

FAO (Food and Agriculture Organisation of the United Nations), 2001. Global Forest Resources Assessment 2000. FAO, Rome.

Fleischbein, K., Wilcke, W., Goller, R., Valarezo, C., Zech, W., Knoblich, K., 2005. Rainfall interception in a lower montane forest in Ecuador: effects of canopy properties. Hydrol. Process. 19, 1355-1371.

Gash, J.H.C., Lloyd, C.R., Lachaud, G., 1995. Estimating sparse forest rainfall interception with an analytical model. J. Hydrol. 170, 79-86.

Gradstein, S.R., Kessler, M., Pitopang, R. Tree species diversity relative to human land uses in tropical rain forest margins in Central Sulawesi. In: Tscharntke, T., Leuschner, Ch., Guhardja, E., Zeller, M. (Eds.), The Stability of Tropical Rainforest Margins: Linking Ecological, Economic and Social Constraints of Land Use and Conservation. Springer, Berlin, Heidelberg, New York, in press.

Grip, H., Fritsch, J.-M., Bruijnzeel, L.A., 2004. Soil and water impacts during forest conversion and stabilisation of new land use. In: Bonnell, M., Bruijnzeel, L.A. (Eds.), Forests, Water and People in the Humid Tropics. Cambridge University Press, Cambridge, pp. 561-589.

Hamann, A., Barbon, E.B., Curio, E., Madulid, D.A., 1999. A botanical inventory of a submontane tropical rainforest on Negros Island, Philippines. Biodiv. Conserv. 8, 1017-1031.

Herwitz, S.R., 1985. Interception storage capacities of tropical rainforest canopy trees. J. Hydrol. 77, 237-252.

Helmi, I., 2005. Local people are well-placed to develop zonation plans in Indonesia's Lore Lindu National Park. Trop. For. Update 15, 31-32.

Hodnett, M., da Silva, L.P., da Rocha, H., Cruz Senna, R., 1995. Seasonal soil water storage changes beneath central Amazonian rainforest and pasture. J. Hydrol. 170, 233-254.

Hölscher, D., Köhler, L., van Dijk, A.I.J.M., Bruijnzeel, L.A., 2004. The importance of epiphytes to total rainfall interception by a tropical montane rainforest in Costa Rica. J. Hydrol. 292, 308-322.

Hölscher, D., Mackensen, J., Roberts, J.M., 2005. Forest recovery in the humid tropics: changes in vegetation structure, nutrient pools and the hydrological cycle. In: Bonnell, M., Bruijnzeel, L.A. (Eds.), Forests, Water and People in the Humid Tropics. Cambridge University Press, Cambridge, pp. 598-621.

Holwerda, F., Scatena, F.N., Bruijnzeel, L.A., 2006. Throughfall in a Puerto Rican lower montane rain forest: a comparison of sampling strategies. J. Hydrol. 327, 592-602.

Jordan, C.F., Heuveldop, J., 1981. The water budget of an Amazonian rain forest. Acta Amaz. 11, 87-92.

Kessler, M., Keßler, P.J.A., Gradstein, S.R., Bach, K., Schmull, M., Pitopang, R., 2005. Tree diversity in primary forests and different land use systems in Central Sulawesi, Indonesia. Biodiv. Conserv. 14, 547-560.

Kelliher, F.M., Leuning, R., Schulze, E.D., 1993. Evaporation and canopy characteristics of coniferous forests and grasslands. Oecologia 95, 153-163.

Köhler, L., Hölscher, D., Leuschner, Ch., 2006. Above-ground water and nutrient fluxes in three successional stages of Costa Rican montane oak forest with contrasting of epiphyte abundance. In: Kappelle, M. (Ed.), Ecology and Conservation of Neotropical Montane Oak Forests. Springer, Berlin, pp. 271-282.

Kitamura, S., Suzuki, S., Yumoto, T., Chuailua, P., Plongmai, K., Poonswad, P., Noma, N., Maruhashi, T., Suckasam, C., 2005. A botanical inventory of a 
tropical seasonal forest in Khao Yai National Park, Thailand: implications for fruit-frugivore interactions. Biodiv. Conserv. 14, 1241-1262.

Kumagai, T., Katul, G.G., Saitoh, T.M., Sato, Y., Manfroi, O.J., Morooka, T., Ichie, T., Kuraji, K., Suzuki, M., Porporato, A., 2004. Water cycling in a Bornean tropical rain forest under current and projected precipitation scenarios. Water Resour. Res. 40, W01104.

Kumagai, T., Saitoh, T.M., Sato, Y., Takahashi, H., Manfroi, O.J., Morooka, T., Kuraji, K., Suzuki, M., Yasunari, T., Komatsu, H., 2005. Annual water balance and seasonality of evapotranspiration in a Bornean tropical rainforest. Agric. For. Meteor. 128, 81-92.

Lloyd, C.R., Marques, A. de O.F., 1988. Spatial variability of throughfall and stemflow measurements in Amazonian rainforest. Agric. For. Meteor. 42, 63-73.

Manfroi, O.J., Koichiro, K., Suzuki, M., Tanaka, N., Kume, T., Nakagawa, M., Kumaigai, T., Nakashizuka, T., 2006. Comparison of conventionally observed interception evaporation in a $100-\mathrm{m}^{2}$ subplot with that estimated in a 4-ha area of the same Bornean lowland tropical forest. J. Hydrol. 329, 329-349.

Manfroi, O.J., Koichiro, K., Nobuaki, T., Masakazu, S., Nakagawa, M., Nakashizuka, T., Chong, L., 2004. The stemflow of trees in a Bornean lowland tropical forest. Hydrol. Process. 18, 2455-2474.

Roberts, J.M., Gash, J.H.C., Tani, M., Bruijnzeel, L.A., 2004. Controls on evaporation in lowland tropical rainforest. In: Bonnell, M., Bruijnzeel, L.A.
(Eds.), Forests, Water and People in the Humid Tropics. Cambridge University Press, Cambridge, pp. 287-313.

Sri-Gernyuang, K., Kanzaki, M., Mizuno, T., Noguchi, H., Teejuntuk, S., Sungpalee, C., Hara, M., Yamakura, T., Sahunalu, P., Dhanmanonda, P., Bunyavejchewin, S., 2003. Habitat differentiation of Lauraceae species in a tropical lower montane forest in northern Thailand. Ecol. Res. 18, 1-14.

Steinhardt, U., 1979. Untersuchungen über den Wasser- und Nährstoffhaushalt eines andinen Wolkenwaldes in Venezuela. Göttinger Bodenkundliche Berichte 56, Göttingen, 185 pp.

Tobón Marin, C., Bouten, W., Sevink, J., 2000. Gross rainfall and its partitioning into throughfall, stemflow and evaporation of intercepted water in four forest ecosystems in western Amazonia. J. Hydrol. 237, 40-57.

Trichton, V., Walter, J.M.N., Laumonier, Y., 1998. Identifying spatial patterns in the tropical rain forest structure using hemispherical photographs. Plant Ecol. 137, 227-244.

Ubarana, V.N., 1996. Observations and modelling of rainfall interception at two experimental sites in Amazonia. In: Gash, J.H.C., Nobre, C.A., Roberts, J.M., Victoria, R.L. (Eds.), Amazonian Deforestation and Climate. John Wiley, Chichester, pp. 151-162.

van Dijk, A.I.J.M., Bruijnzeel, L.A., 2001. Modelling rainfall interception by vegetation of variable density using an adapted analytical model. Part 1. Model description. J. Hydrol. 247, 230-238. 


\section{3}

\section{Vertical patterns and duration of surface wetness}

in an old-growth tropical montane forest, Indonesia

Johannes Dietz, Christoph Leuschner, Dirk Hölscher, Heinrich Kreilein

In:

Flora (in press)

FLORA50103, doi:10.1016/j.flora.2006.03.004 


\title{
Vertical patterns and duration of surface wetness in an old-growth tropical montane forest, Indonesia
}

\author{
Johannes Dietz ${ }^{\mathrm{a}, \mathrm{b}}$, Christoph Leuschner ${ }^{\mathrm{a}, *}$, Dirk Hölscher ${ }^{\mathrm{b}}$, Heinrich Kreilein ${ }^{\mathrm{c}}$ \\ a Department of Plant Ecology, University of Göttingen, Untere Karspüle 2, D-37073 Göttingen, Germany \\ ${ }^{\mathrm{b}}$ Department of Tropical Silviculture, Büsgenweg 1, University of Göttingen, D-37077 Göttingen, Germany \\ ${ }^{\mathrm{c}}$ Department of Bioclimatology, Büsgenweg 2, University of Göttingen, D-37077 Göttingen, Germany
}

Received 7 October 2005; accepted 2 March 2006

\begin{abstract}
In tropical montane forests, the wetness of leaf surfaces is an important parameter which may influence gas exchange, growth and vitality of leaves, and forest productivity. Thirty surface wetness sensors were operated during May-August 2004 in a vertical profile inside an old-growth lower montane rain forest of Central Sulawesi, Indonesia, with the objective to analyse spatial and temporal patterns of surface wetness and to relate wetness duration to the microclimate inside the stand. The canopy was wet during $25-30 \%$ of time in this study period. In a dry period, however, surface wetness lasted for only $5 \%$ of the time, whereas the canopy was wet during $45-55 \%$ of the time in a rainy period. In the lower shade canopy, surface wetness continuously existed for periods of up to $22 \mathrm{~h}$ and more, although rainfall occurred only during afternoon thunderstorms of limited duration. The long duration of surface wetness has implications for forest interception models, which assume a complete drying of the canopy between subsequent rainfall events. In periods with rainfall, leaf wetness typically occurred in the afternoon, evening and first half of the night because intercepted water persisted on the leaves until about midnight. In dry periods, in contrast, surface wetness was mainly caused by dewfall in the second half of the night, and it occurred mainly in the uppermost canopy where radiative heat losses resulted in a substantial under-cooling of the leaves. Ecophysiological and hydrological importance is suggested by the long duration of surface wetting in this stand with possible implications for gas exchange, leaf growth, leaf colonization by epiphylls and the forest water balance.
\end{abstract}

(C) 2006 Elsevier GmbH. All rights reserved.

Keywords: Dewfall; Dew point temperature; Microclimatology; Rainfall patterns; Saturation deficit

\section{Introduction}

Tropical montane forests exist in relatively cool and humid climates where high rainfall amounts prevail. On the slopes of tropical mountains, convective uplift of heated air masses forces water vapour to condensate at elevations of about 1500-3500 m (Hastenrath, 1991).

\footnotetext{
${ }^{*}$ Corresponding author.

E-mail address: cleusch@gwdg.de (C. Leuschner).
}

Montane forests receive three different types of precipitation, i.e. vertical rainfall, fog interception (horizontal precipitation) and dewfall. Vertical rainfall may be as high as $6000 \mathrm{~mm} \mathrm{yr}^{-1}$, and it can exceed $10,000 \mathrm{~mm} \mathrm{yr}^{-1}$ at certain locations. Much less is known about the other two types of precipitation. Water loss with evapotranspiration most likely is comparably small in montane forests since temperature is lower than in the hot lowlands and cloud cover frequently is reducing the radiation load. Therefore, tropical montane forests are 
typically characterized by a high water surplus, which plays an increasing role as a water source for the ever growing cities in tropical countries.

From an ecological perspective, tropical montane forests are characterized by their reduced tree size compared to lowland forests. A variety of hypotheses have been proposed to explain the structural and functional characteristics of tropical montane forests. They include (1) lowered temperatures at higher elevations (Kitayama and Aiba, 2002), (2) temperature-induced nutrient shortage (Tanner et al., 1998), (3) reduced insolation (Letts and Mulligan, 2005), (4) limited root aeration due to poor drainage (Odum et al., 1970), and other environmental constraints that could limit tree growth at higher elevations (Bruijnzeel and Veneklaas, 1998). Grubb (1977) has forwarded the hypothesis that the prevalence of high air humidities should reduce tree transpiration, thereby impairing nutrient uptake and causing nutrient deficiency.

Indeed, climate chamber experiments have shown that very high air humidities can reduce foliar nutrient levels of herbaceous plants (Leuschner, 2002). Letts and Mulligan (2005) present further field-based evidence for the inhibition of photosynthesis and productivity by leaf wetness in neotropical montane cloud forests. High air humidity can also favour pathogen attack of leaves which may reduce plant productivity (Magarey et al., 2005). On the other hand, there is substantial evidence that leaves expand more rapidly under high air humidities, and leaf conductance typically is higher under low saturation deficits which may enhance photosynthetic carbon gain (e.g. Gouvra and Grammatikopoulos, 2003; Hanba et al., 2004). Whether high levels of air humidity are significantly affecting tree growth in tropical montane forests and whether positive or negative effects on growth are prevailing, may largely depend on the duration of periods with saturation deficits close to zero.

Most terrestrial plants are not only exposed to high air humidities in part of their life, but frequently experience liquid water on photosynthetic surfaces as well (Barr and Gillespie, 1987; Harrington and Clark, 1989). In moist tropical environments, leaf surface wetness may be an important growth regulating factor for woody and herbaceous plants because epiphyllic lichens, mosses, fungi and also pathogens are thriving on wet leaf surfaces inhibiting light absorption by the leaf. On the other hand, transpiration rate and xylem water flux, and leaf carbon dioxide uptake may partly be inhibited by a water film covering the stomates (Brewer and Smith, 1994, 1995; Ishibashi and Terashima, 1995). The wetness of plant leaf surfaces is also an important parameter in the deposition process of atmospheric trace gases and pollutants (Klemm et al., 2002). Brewer et al. (1991) hypothesized that a strong selective pressure should exist for the repulsion of water films on leaf surfaces in environments with frequent leaf wetting events.

Until recently, remarkably little has been known about the occurrence of leaf wetness in tropical montane forests and its variation in time and space in the stand. Brewer and Smith (1997) analysed patterns of leaf wetness for montane and subalpine plants in the temperate Rocky Mountains, and Klemm et al. (2002) conducted similar measurements in temperate forests of Europe. We are aware of only very few studies that systematically monitored surface wetness in tropical montane forests for extended periods (Letts and Mulligan, 2005; Leuschner and Schulte, 1991). Here, we present data of a 3-month study with 30 leaf wetness sensors mounted in a vertical profile inside a lower montane rainforest in Central Sulawesi, Indonesia. Study objective was to analyse leaf wetness patterns in rainless and rainy periods and to relate wetness patterns to microclimate and rainfall regime.

\section{Methods}

\section{Study site}

The study was conducted in an old-growth tropical lower montane forests at about $1430 \mathrm{~m}$ elevation on the eastern fringes of Lore Lindu National Park near Bariri, province of Poso, Central Sulawesi, Indonesia $\left(1.6579^{\circ} \mathrm{S}, 120.1735^{\circ} \mathrm{E}\right)$. The study site is located on a level plateau. A $70 \mathrm{~m}$ tall meteorological scaffolding tower inside the forest was used for mounting surface wetness and micrometeorological sensors in a vertical profile in the stand. The forest is a closed stand with a stem density ( $>10 \mathrm{~cm}$ in $\mathrm{dbh}$ ) of $557 \mathrm{ha}^{-1}$, and a maximum tree height of $41.5 \mathrm{~m}$. The undulating surface of the forest canopy reaches about $32 \mathrm{~m}$, and the height of the average tree (according to $\mathrm{dbh}$ ) is $24.7 \mathrm{~m}$. With an estimated number of $100-150$ tree species pre hectare, the forest is highly diverse (Kessler et al., 2005). The most species-rich tree family in the study region is the Lauraceae. A structural analysis inside the forest revealed that the mean height of the lowest branch was $12.2 \mathrm{~m}$. The understorey contains a sparse layer of young tree individuals. Except for small-scale disturbances in the understorey during the tower construction phase, the forest shows no signs of major anthropogenic impact.

\section{Leaf wetness and microclimatological sensors}

We used surface wetness sensors of Skye Instruments Ltd. (Powys, UK) to estimate the duration of leaf surface wetness at different heights inside the forest. Wetness is recorded through changes in current output 
that occur when a DC circuit is shortcut by a water film on the surface of a gold-covered horizontal plate of $80 \mathrm{~mm} \times 80 \mathrm{~mm}$ in size. The sensors were mounted on horizontal poles that allowed positioning them inside the tree canopies close to the leaves. We installed 30 sensors in $1.5 \mathrm{~m}$ intervals from 1.5 to $33.0 \mathrm{~m}$ above the ground. At 1.5, 3.0, 4.5, 6.0, 27.0, 28.5, 30.0, 31.5 and $33.0 \mathrm{~m}$ height, two sensors were operated in parallel in order to obtain average values of surface wetness. To allow for measurements in the undisturbed understorey, all wetness sensors below $6.0 \mathrm{~m}$ height were mounted on a separate pole $12 \mathrm{~m}$ east of the tower base. Air temperature and air humidity were measured using radiation-shielded and ventilated dry and wet bulb thermometers (Friedrichs 3030.0000 BG sensors, Theodor Friedrichs \& Co., Schenefeld, Germany). They were placed $2 \mathrm{~m}$ above ground on a separate weather station in the understorey approx. $15 \mathrm{~m}$ southwest of the tower base. Inside the canopy, temperature and air humidity were measured at 22 and $36 \mathrm{~m}$ above ground on horizontal poles protruding $1.5 \mathrm{~m}$ from the northeastern corner of the tower. Precipitation was recorded with two Friedrichs 7041.0000 ombrometers placed at a distance of $3 \mathrm{~m}$ to each other on the top of the tower at $69 \mathrm{~m}$ above ground.

Surface wetness data were recorded during a 3-month period in 2004 using a CR10X logger combined with an AM16/32 relay multiplexer (both Campbell Scientific, Inc., Shepshed, UK). Data were read from all 30 sensors in $15 \mathrm{~s}$ intervals and stored as 5 min means. Microclimate data were recorded separately at each height with a Friedrichs Kombilog 1020 logger (Theodor Friedrichs \& Co., Schenefeld, Germany). Sensors were scanned every $10 \mathrm{~s}$ and data were stored as 5 min means.

\section{Results}

\section{Diurnal courses of microclimate parameters in wet and dry periods}

Two example days from June 2004 with typical, but contrasting, weather conditions were selected for analysing the interdependency of air temperature $\left(T_{\mathrm{a}}\right)$, atmospheric saturation deficit $(\Delta e)$ and measured surface wetness in the old-growth forest near Bariri. June 11 stands for days with a cloudless morning and subsequent formation of convective clouds around noon, followed by thunderstorms with heavy rainfall in the afternoon and evening (Fig. 1a). In contrast, June 22 exemplifies a bright cloudless day without rainfall as it is characteristic for about $30 \%$ of the days of a year at Bariri (Fig. 1b).

On rainy June 11, the vertical air temperature gradient from the forest floor through the canopy to the turbulent air layer above the canopy approached zero during the night-time hours $(18 \mathrm{~h}$ to $6 \mathrm{~h})$. On dry June 22 , in contrast, the inner canopy at $22 \mathrm{~m}$ height remained by c. $0.5 \mathrm{~K}$ warmer than the air layer $6 \mathrm{~m}$ above the canopy ( $36 \mathrm{~m}$ height) for most of the night (unfortunately, the temperature sensor at $1.5 \mathrm{~m}$ above
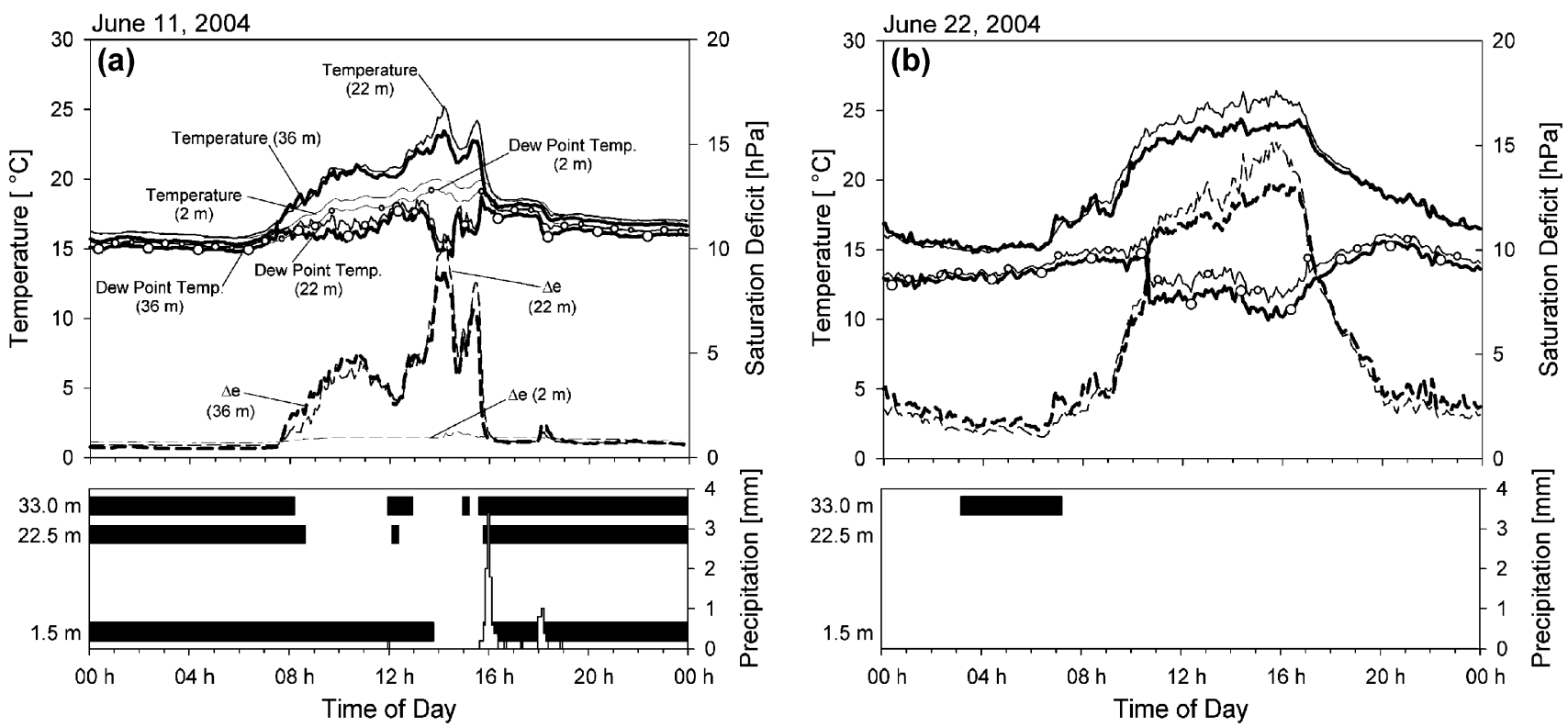

Fig. 1. (Upper panels) Daily courses of air temperature, dew point temperature and atmospheric saturation deficit ( $\Delta e$ ) at 2,22 and $36 \mathrm{~m}$ height inside and above the canopy of the Bariri forest on June 11 with afternoon rainfall (a), and on dry June 22, 2004 (b). (Lower panels) Duration of surface wetness at 1.5, 22.5 and $33.0 \mathrm{~m}$ height inside the forest and precipitation on June 11 (a) and June 22 (b). 
the forest floor failed on this day). During the daylight hours of June 22 , the inner canopy was by $1-2 \mathrm{~K}$ warmer than the air above the canopy revealing a substantial canopy over-temperature, whereas the canopy was only $0.5-1 \mathrm{~K}$ warmer than the air on rainy June 11 (Fig. 1a and $b$ ).

Striking differences between the wet and the dry days existed also with respect to the atmospheric saturation deficit. On rainy June $11, \Delta e$ remained close to zero during the night-time hours inside and above the canopy, and also did so at $1.5 \mathrm{~m}$ height close to the forest floor during the daytime hours. On dry June 22, in contrast, $\Delta e$ remained at $2-3 \mathrm{hPa}$ in and above the stand during the night (Fig. 1a and b). The saturation deficit reached daytime maxima of 15 and $10 \mathrm{hPa}$ in the early afternoon of the dry and the rainy day, respectively. Remarkably, $\Delta e$ maxima were by 2 or $3 \mathrm{hPa}$ larger inside the canopy $(22 \mathrm{~m})$ than in the turbulent air above the trees $(36 \mathrm{~m})$ because the canopy maintained a significant over-temperature during the day.

Being determined by air temperature and saturation deficit, the dew point temperature $\left(T_{\mathrm{DP}}\right)$ remained very close to $T_{\mathrm{a}}$ during the night on rainy June 11, but it was below air temperature during the night of dry June 22 (Fig. 1a and b). Thus, on rainy June 11, dew point was approached during $24 \mathrm{~h}$ of the day $(0-24 \mathrm{~h})$ at the forest floor, and on $17-18 \mathrm{~h}$ of the day inside and above the canopy. In contrast, our temperature sensors did never record a drop of $T_{\mathrm{a}}$ to dew point temperature on dry June 22.

The results on the daily courses of $T_{\mathrm{a}}$ and $T_{\mathrm{DP}}$ closely match with the duration of recorded surface wetness. On rainy June 11, the wetness sensors indicated a surface water film on 22 of $24 \mathrm{~h}$ of the day at the forest floor, and on 16-18 h of the day inside and above the canopy. In contrast, on dry June 22, only the wetness sensors at maximum canopy height $(33 \mathrm{~m})$ gave a positive signal for about $4.5 \mathrm{~h}$ before sunrise when $T_{\mathrm{a}}$ dropped toward $T_{\mathrm{DP}}$ (although it never met dew point temperature, Fig. 1b).

\section{Diurnal and seasonal variation of leaf surface wetness in the stand}

In a 3-week period with average rainfall conditions (May 21-June 13, 2004), about $45 \%$ of the days received sufficient rainfall to moisten the entire forest canopy from the top to the forest floor in the afternoon. This is indicated by the frequency of surface wetness at sunset (7 p.m.) in Fig. 2a. On a typical evening of this measuring period, $\Delta e$ was still larger than $1.5 \mathrm{hPa}$ throughout the canopy thereby preventing the occurrence of dewfall in the first half of the night. During midnight, air temperature inside the canopy typically had dropped by $2-3 \mathrm{~K}$, thereby reducing the atmo-

\section{Duration of Surface Wetness [\%]}
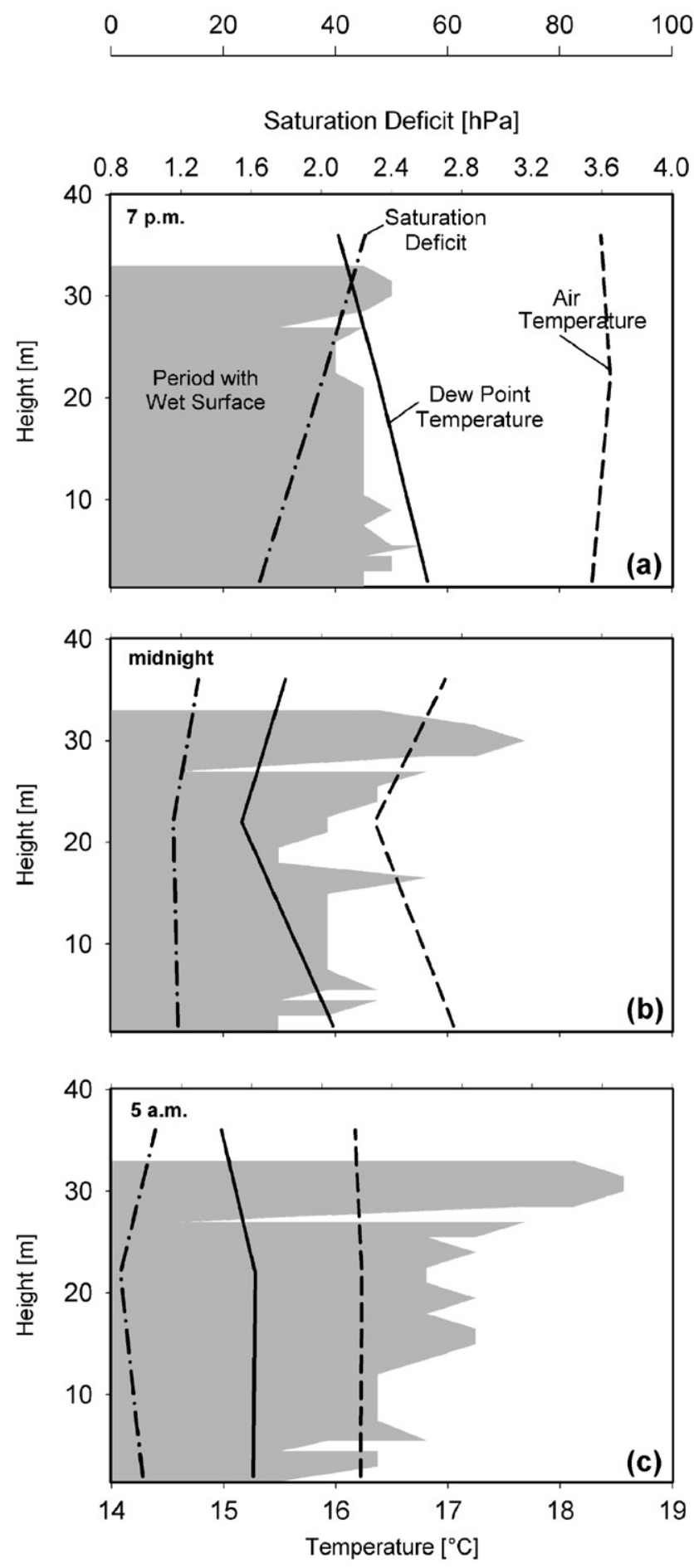

Fig. 2. Average duration of surface wetness (in per cent of the time) after sunset (7 p.m., a), at midnight (b) and before sunrise (c) in the period May 21-June 13, 2004, in a vertical profile inside the Bariri forest as measured with 30 surface wetness sensors mounted between 1.5 and $33.0 \mathrm{~m}$ height. Average vertical profiles of air temperature, dew point temperature and atmospheric saturation deficit after sunset, at midnight and before sunrise are also depicted for this period. 
spheric saturation deficit to about $1 \mathrm{hPa}$. This allowed for the occurrence of dewfall in the upper canopy (Fig. 2b). In about $90 \%$ of the nights, surface wetness was recorded in the upper canopy (at about $30 \mathrm{~m}$ ) shortly before sunrise at $5 \mathrm{a} . \mathrm{m}$. This indicates that dewfall apparently is occurring regularly from midnight onwards in the upper canopy, but not in the lower canopy. After sunrise, surface wetness rapidly disappeared in the sun-lit canopy on all days (see Fig. 1, lower panel).

The average duration of surface wetness in the stand differed greatly in dependence of the rainfall regime. This is visible from a comparison of periods with different rainfall amounts in the 11-week measuring period. When analysing the whole study period (May 11-August 11, 2004), the canopy was covered by water during $25-30 \%$ of the time (Fig. 3d). In this period, upper and lower canopy strata behaved similar with respect to wetness duration. A comparison of 2-week periods with either very low $(0.2 \mathrm{~mm})$, low to medium $(19.2 \mathrm{~mm})$, or high rainfall amounts $(101.4 \mathrm{~mm})$ showed that surface wetness was highly different between dry and wet periods. Wetness lasted for less than $5 \%$ of the time in the dry period, and leaf wetness occurred for much longer in the uppermost canopy layer indicating the influence of occasional dewfall or fog interception (Fig. 3a). During the low-to-medium rainfall period, this trend along the vertical profile was inverted. While leaves remained wet for $20-25 \%$ of the time, wetness lasted longest near the forest floor, where insolation and turbulent energy exchange with the atmosphere is reduced (Fig. 3b). Finally, in the rainy period, the foliage remained wet for $45-55 \%$ of the time and the difference between upper and lower canopy strata disappeared (Fig. 3c). Remarkably, these vertical differences in wetness patterns inside the stand fade when leaf wetness is averaged over the entire study period (Fig. 3d).

\section{Discussion}

According to the rain gauge data, the study region receives only moderate annual amounts of vertical rainfall $\left(1830 \mathrm{~mm} \mathrm{yr}^{-1}\right)$ compared to other tropical lower montane or montane forests. However, this number does only cover rainfall collected in gauges; this situation occurs on about $65 \%$ of the days of a year in the study region. In tropical montane forests and especially in cloud forests, interception of wind-driven fog and rain by the vegetation may add substantial amounts of moisture to the system (Bruijnzeel, 2001; Kämmer, 1974). In a montane cloud forest of Guatemala at an altitude of $2550 \mathrm{~m}$, an equivalent of fog precipitation of $203 \mathrm{~mm}$ was estimated by comparing throughfall and incident precipitation data. Fog pre-

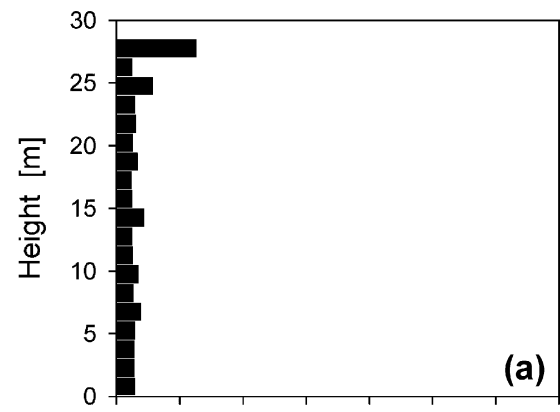

Dry Period

16/06 - 30/06/04

Total Rainfall:

$0.2 \mathrm{~mm}$
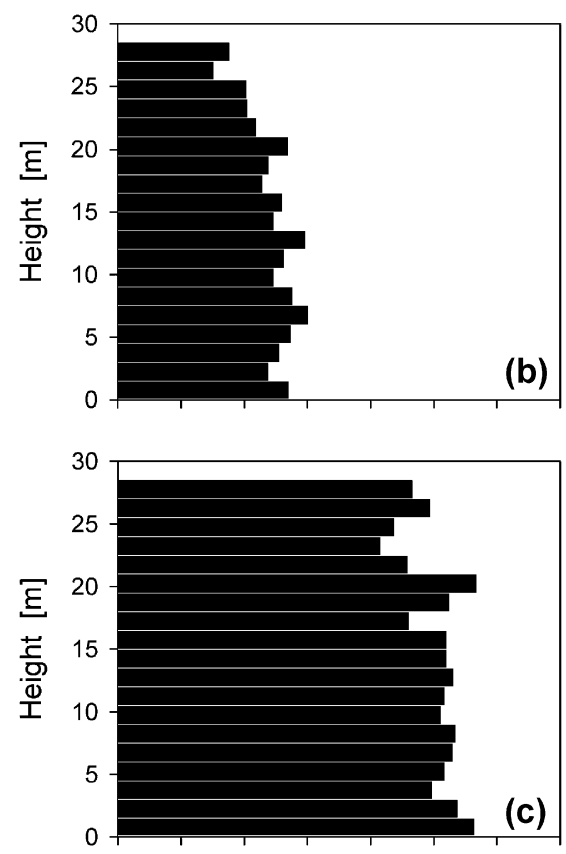

Low-Rainfall Period 16/07 - 30/07/04

Total Rainfall:

$19.2 \mathrm{~mm}$

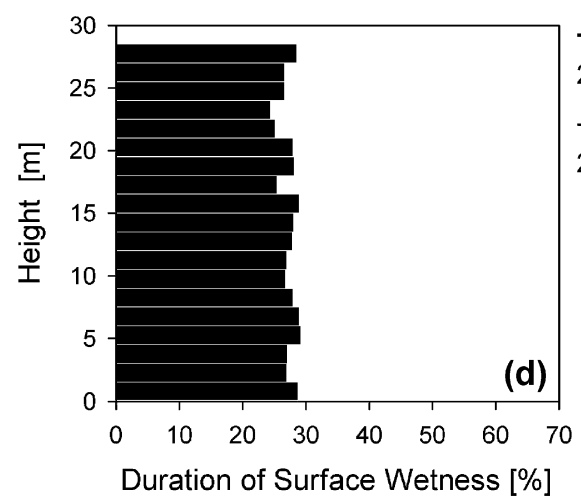

Wet Period

01/06 - 15/06/04

Total Rainfall: $101.4 \mathrm{~mm}$

Total Period

$21 / 05-11 / 08 / 04$

Total Rainfall:

$221.1 \mathrm{~mm}$

Fig. 3. Average duration of surface wetness (in per cent of the time) in a vertical profile inside the Bariri forest in a dry 2-week period (June 16-June 30, (a)), a low-to-medium rainfall period (July 16-July 30, (b)), a wet period (June 1-June 15, (c)), and during the entire measuring period (May 15-August 11).

cipitation was assumed during sampling periods when throughfall exceeded incident precipitation (Holder, 2003). However, the author himself states that the amount of fog precipitation in this study is underestimated. The quantification of the volume added by 
fog is difficult and reliable data for tropical montane forest are lacking so far. By using a variety of methods including stable hydrogen and oxygen isotopes, Dawson (1998) estimated for Californian coastal redwood forests that $34 \%$ of the annual water input was derived from fog drip. Throughfall data from the Bariri forest in Sulawesi point at a relatively low importance of fog interception at this site probably because of the lower montane elevation.

Despite a comparably low frequency of fog during the day, leaf wetness is an important ecological factor in this forest. Surface wetness was present in about $30 \%$ of the time of the total measuring period, and in $50 \%$ or more of the rainy period. On rainy days, the upper canopy was often influenced by surface wetness for more than $16 \mathrm{~h}$ from the early afternoon onwards till the next morning. In the lower shade canopy close to the forest floor, wetness was continuously present for periods of $22 \mathrm{~h}$ and even more, although rainfall occurred only during thunderstorms of limited duration in the afternoon. Thus, epiphyllic liverworts, lichens and fungi are experiencing favourable moisture conditions on the leaf surface in this forest for several daylight hours and during the whole or most of the night as well. Vigorous growth of lightcapturing epiphylls and, presumably, of pro- and eukaryotic pathogens on the leaf surface, that thrive in the water film on the leaf, may well explain why many trees in tropical montane forests have average leaf longevities not longer than about 16 months (Moser, pers. commun.).

In fact, the consequences for leaf growth of trees that follow from light competition by epiphyllic organisms may be more relevant than the effects on stomatal conductance and photosynthesis that are caused by the inhibition of gas exchange due to leaf wetness and high air humidity. Surveys of tropical montane trees at 1000-3000 m elevation in South Ecuador showed that the vast majority of species were hypostomatous (Schuldt, pers. commun.). Own observation in the Bariri forest suggests that most tree species are experiencing leaf wetness only at the upper, and not at the lower surface, unless leaf orientation is not vertically upward or downward which is rarely the case (Bohman, 2004). In fact, rainfall and cloud interception are occurring mainly on the upper (adaxial) leaf side, whereas the lower (abaxial) surface is moistened only by fine mist with water droplets in the $\mu \mathrm{m}$ scale (Letts and Mulligan, 2005). We assume that physical inhibition of gas exchange by leaf wetness should be of minor importance in this forest. Very low atmospheric saturation deficits, as are occurring in periods of leaf wetness, must result in very low or zero transpiration rates, whereas photosynthesis should proceed albeit at reduced rates. Therefore, leaf wetness should increase photosynthetic water use efficiency.
The surface wetness and microclimate data of this forest indicate that the occurrence of leaf wetness in the afternoon, evening and the first half of the night is normally a consequence of afternoon rainfall events of limited duration. Since we did not conduct direct measurements of fog interception, we cannot assess the relative contribution of horizontal precipitation to measured leaf wetness. If sufficient rainfall has occurred, the leaves may remain wet until the early morning. On days without rainfall, or when rain is followed by a late afternoon with sunshine sufficient to dry up the canopy, leaf wetness in night-time and morning is most often a consequence of dewfall. Dew formation seems to start around midnight as a consequence of under-temperatures of the upper canopy compared to the air in the course of substantial heat losses with longwave radiation losses from the leaves. In such nights, leaf wetness often concentrates in the upper canopy and does not reach to the lowest canopy strata, probably because condensation heat from dewfall is preventing any further cooling of the lower canopy. We often recorded surface wetness in the canopy although air temperature remained $0.5-1.0 \mathrm{~K}$ above dewpoint temperature. Most likely, this situation is caused by significant under-temperatures of the leaves compared to the surrounding air due to radiative energy losses of the leaf surface.

Leaf wetness following afternoon rainfall events seems to last longer in the lower canopy because the sun canopy is drying more rapidly during the daylight hours. In contrast, surface wetness on more or less clear days as caused by night-time dewfall has a longer duration in the upper canopy because of the negative radiation balance of the leaves during the night.

Our results on leaf wetness patterns are not only relevant for understanding the ecophysiology of tropical trees, but they also have implications for the hydrology of tropical montane forests. The surprisingly long duration of surface wetness in this stand raises questions upon earlier modelling studies of rainfall interception. For example, the frequently applied Gash model of rainfall interception in forests (Gash et al., 1995) bases on the assumption that the canopy dries completely between subsequent rainfall events. In the Bariri forest, this seems not to be the case on many occasions. A possible conclusion would be that an application of the Gash model or its derivates (Gash, 1979; Gash et al., 1995) will fail. For canopies with long wetness periods, interception models that simulate changes in the amount of stored water on canopy and trunk surfaces by means of a running water balance seem to be more suitable. An example would be the Rutter model of rainfall interception (Rutter et al., 1971), which requires detailed information on the intensity of rainfall events together with meteorological variables related to evaporation. 


\section{Acknowledgements}

This study has been conducted in the framework of the German-Indonesian STORMA project ('Stability of rainforest margins in Indonesia', SFB 552, subproject B4), funded by the German Research Council (DFG). The financial support is gratefully acknowledged.

\section{References}

Barr, A., Gillespie, T.J., 1987. Maximum wetness duration for water drops on leaves in the field. Agric. For. Meteorol. 41, 267-274.

Bohman, K., 2004. Functional and morphological diversity of trees in different land use types along a rainforest margin in Sulawesi, Indonesia. Ph.D. Thesis, University of Göttingen.

Brewer, C.A., Smith, W.K., 1994. What's so bad about being wet all over: investigating the ecological significance of leaf surface wetness. Am. Biol. Teacher 58, 414-417.

Brewer, C.A., Smith, W.K., 1995. Leaf surface wetness and gas exchange in the pond lily Nuphar polysepalum (Nymphaeaceae). Am. J. Bot. 82, 1271-1277.

Brewer, C.A., Smith, W.K., 1997. Patterns of leaf surface wetness for montane and subalpine plants. Plant Cell Environ. 20, 1-11.

Brewer, C.A., Smith, W.K., Vogelmann, T.C., 1991. Functional interaction between leaf trichomes, leaf wettability and the optical properties of water droplets. Plant Cell Environ. 14, 955-962.

Bruijnzeel, L.A., 2001. Hydrology of tropical montane cloud forests: a reassessment. Land Use Water Resour. Res. 1, 1.1-1.18.

Bruijnzeel, L.A., Veneklaas, E.J., 1998. Climatic conditions and tropical montane forest productivity: the fog has not lifted yet. Ecology 79, 3-9.

Dawson, T.E., 1998. Fog in the California redwood forest: ecosystem inputs and use by plants. Oecologia 117, 476-485.

Gash, J.H.C., 1979. An analytical model of rainfall interception of forests. Quart. J. Roy. Meteorol. Soc. 105, 43-55.

Gash, J.H.C., Lloyd, C.R., Lachaud, G., 1995. Estimating sparse forest rainfall interception with an analytical model. J. Hydrol. 170, 79-86.

Gouvra, E., Grammatikopoulos, G., 2003. Beneficial effects of direct foliar water uptake on shoot water potential of five chasmophytes. Can. J. Bot. 81, 1278-1284.

Grubb, P.J., 1977. Control of forest growth and distribution on wet tropical mountains: with special reference to mineral nutrition. Ann. Rev. Ecol. Syst. 8, 83-107.

Hanba, Y.T., Moriya, A., Kimura, K., 2004. Effect of leaf surface wetness and wettability on photosynthesis in bean and pea. Plant Cell Environ. 27, 413-421.
Harrington, D.F., Clark, C., 1989. Reduction in light reflectance of leaves of Encelia densifolia (Asteraceae) by trichome wetting. Madrono 36, 180-186.

Hastenrath, S., 1991. Climate Dynamics of the Tropics. Kluwer, Dordrecht.

Holder, C.D., 2003. Fog precipitation in the Sierra de las Minas Biosphere Reserve, Guatemala. Hydrol. Process. 17, 2001-2010.

Ishibashi, M., Terashima, I., 1995. Effects of continuous leaf wetness on photosynthesis: adverse aspects of rainfall. Plant Cell Environ. 18, 431-438.

Kämmer, F., 1974. Klima und Vegetation von Teneriffa besonders im Hinblick auf den Nebelniederschlag. Scr. Geobot. (Göttingen) 7, 1-78.

Kessler, M., Keßler, P.J.A., Gradstein, S.R., Bach, K., Schmull, M., Pitopang, R., 2005. Tree diversity in primary forest and different land use systems in Central Sulawesi, Indonesia. Biodiversity Conservat. 14, 547-560.

Kitayama, K., Aiba, S.I., 2002. Ecosystem structure and productivity of tropical rain forests along altitudinal gradients with contrasting soil phosphorus pools on Mount Kinabalu, Borneo. J. Ecol. 90, 37-51.

Klemm, O., Milford, C., Sutton, M.A., Spindler, G., van Putten, E., 2002. A climatology of leaf surface wetness. Theor. Appl. Climatol. 71, 107-117.

Letts, M.G., Mulligan, M., 2005. The impact of light quality and leaf wetness on photosynthesis in north-west Andean tropical montane cloud forest. J. Trop. Ecol. 21, 549-557.

Leuschner, Ch., 2002. Air humidity as an ecological factor for woodland herbs: leaf water status, nutrient uptake, leaf anatomy and productivity of eight species when grown at low or high vpd. Flora 197, 262-274.

Leuschner, Ch., Schulte, M., 1991. Microclimatological investigations in the tropical alpine scrub of Maui, Hawaii: evidence for a drought-induced alpine timberline. Pac. Sci. 45, 152-168.

Magarey, R.D., Russo, J.M., Seem, R.C., Gadoury, D.M., 2005. Surface wetness duration under controlled environmental conditions. Agric. For. Meteorol. 128, 111-122.

Odum, H.T., Abbott, W., Sealander, R.K., Golley, F.B., Wilson, R.F., 1970. Estimates of chlorophyll and biomass of the Tabunuco forest of Puerto Rico. In: Odum, H.T., Pigeon, R.F. (Eds.) A Tropical Rain Forest: a Study of Irradiation and Ecology at El Verde, Puerto Rico. US Atomic Energy Commission, Washington, DC, pp. 13-19.

Rutter, A.J., Kershaw, K.A., Robins, P.C., Morton, A.J., 1971. A predictive model of rainfall interception in forests: I. Derivation of the model from observations in a plantation of Corsican pine. Agric. Meteorol. 9, 367-384.

Tanner, E.V.J., Vitousek, P.M., Cuevas, E., 1998. Experimental investigation of nutrient limitation of forest growth on wet tropical mountains. Ecology 79, 10-22. 


\section{4}

Spatial and temporal variability of throughfall in a tropical old-growth forest

and an agroforestry system in Sulawesi (Indonesia)

Charlotte Klank, Johannes Dietz, Dirk Hölscher, Christoph Leuschner

In:

Agroforestry Systems (under review) AGFO176 


\title{
Spatial variability of throughfall in a tropical old-growth forest and an agroforestry system (Sulawesi, Indonesia)
}

\author{
Ch. Klank · J. Dietz $\cdot$ D. Hölscher $\cdot$ Ch. Leuschner
}

Received: 12 May 2006 / Reviewers assigned: 18 Sept 2006 / Currently under review

\begin{abstract}
This study investigates the relative amount and spatial variability of canopy throughfall in an old-growth lower montane rainforest and a nearby cacao/coffee agroforestry system with shade trees in Central Sulawesi, Indonesia. Study aims were to quantify spatial throughfall variability for different gross precipitation intensities and to relate variability to the heterogeneity of leaf area in the stands. We intensively studied 26 days of rainfall using 30 throughfall collectors per stand that were operated in a roving gauge modus in the $32 \mathrm{~m}$ by $50 \mathrm{~m}$ plots. Canopy openness, leaf area index (LAI) and mean leaf angle were investigated by optical canopy analysis. Mean relative throughfall (rTF, in percent of gross precipitation) was $39.0( \pm 27) \%$ in the natural forest, and 75.7 $( \pm 45.1) \%$ in the agroforestry stand. The coefficient of variation (CV) for the spatial heterogeneity of rTF within the plots was very high for small rainfall amounts $(<2 \mathrm{~mm})$ in the natural forest, but rapidly decreased with increasing rainfall. In contrast, CV was lower for small rainfall
\end{abstract}

\section{Ch. Klank}

Institute for Terrestrial Ecosystems, Ecosystem Management, Swiss Federal Institute of Technology Zurich, Switzerland

J. Dietz $\cdot$ Ch. Leuschner

Albrecht-von-Haller-Institute of Plant Sciences, Dept. of

Plant Ecology, University of Göttingen, Germany

J. Dietz · D. Hölscher

Institute of Silviculture, Dept. of Tropical Silviculture,

University of Göttingen, Germany

Ch. Leuschner $(\square)$

Dept. of Plant Ecology, Albrecht-von-Haller-Institute of Plant Sciences, University of Göttingen, Untere Karspüle 2, D-37073 Göttingen, Germany

e-mail: cleusch@gwdg amounts in the agroforestry stand and remained constant or tended to increase with increasing rainfall in this multi-layered stand. We conclude that conversion of natural forest to agroforestry systems with sparse shade tree cover, which is a widespread practice in the remaining rainforests of South-East Asia, changes the throughfall patterns substantially by increasing rTF and its spatial variability, and by resulting in very high throughfall maxima at certain plot locations which may increase the risk of soil erosion.

Keywords Canopy gap fraction $\cdot$ Leaf area index Precipitation classes $\cdot$ Roving gauge technique

\section{Introduction}

Tropical deforestation continues at particularly high rates in South-East Asia with about $0.9 \% \mathrm{yr}^{-1}$ of tropical forest being converted annually (Achard et al. 2002). In many regions of Indonesia, Malaysia and other South-East Asian countries, the establishment of agroforestry systems with cacao, coffee and other cash crops is a widespread practice in the rainforest margin zone. Typically, the encroachment starts with the opening of the canopy by selective extraction of 50 to $80 \%$ of the stems for creating suitable growing conditions for shade-tolerant tree crops. They are planted in monospecific or mixed culture under a remaining sparse canopy of rainforest trees. The crop trees will soon grow to a height of 3 to $8 \mathrm{~m}$ forming a relatively dense second canopy layer. Plantations of cacao, coffee, banana and other plants under a sparse tree 
Agroforest Syst (submitted)

canopy are particularly widespread in the margin zones of protected forests in Indonesia where a high population pressure in the border zone is triggering increasing encroachment of the remaining forests (Helmi 2005). Since complete forest conversion is prohibited by law in national parks, regional forest reserves and protection forests, tree crop cultivation inside the opened forest often appears as a promising and accepted alternative to clear-cutting. In fact, agroforestry under remaining forest cover represents a land use type with considerable spatial extension in $\mathrm{Su}-$ lawesi and Kalimantan and in many outer islands of Indonesia.

Since tree height and density of large stems may be altered considerably with the conversion of forest to agroforest plantations (Dietz et al. 2007), considerable changes in the hydrological processes such as interception, throughfall and evapotranspiration are likely to occur. This may have consequences for soil moisture status, soil erosion, and water yield, the latter being particularly important for paddy rice cultivation and urban water demand in the wider forest margin zone.

The hydrological changes that result from the conversion of old-growth tropical forest to agroforestry systems have not been studied in detail so far, despite growing awareness of their relevance for water resources management. Here, we present the results of a comparative study on the throughfall patterns in a natural forest and a nearby agroforest stand in Central Sulawesi. We hypothesize that agroforestry stands have a larger spatial variability of throughfall due to a more heterogeneous structure of the canopy in horizontal and vertical direction. Study aim was to quantify the spatial variability of throughfall with high resolution in both vegetation types by using a large number of collectors and applying the roving gauge technique, and to relate throughfall variability to the heterogeneity of canopy leaf area and leaf orientation.

\section{Methods}

Study sites

The study was conducted in 2004 in two study plots near the village of Toro (01³0.234' S, $\left.120^{\circ} 02.199^{\prime} \mathrm{E}\right)$, district of Donggala, Central Su-
Table 1 Selected features of the study plots.

\begin{tabular}{lcc}
\hline \hline & Natural forest & Agroforest \\
\hline Elevation (m a.s.l.) & 948 & 806 \\
Exposition $\left(^{\circ}\right)$ & 164 & 205 \\
Inclination ( $\left.{ }^{\circ}\right)$ & 32.2 & 37.1 \\
pH $\left(\mathrm{H}_{2} \mathrm{O}\right)$ at $0-10 \mathrm{~cm}$ & 5.3 & 6.7 \\
Max. tree height $(\mathrm{m})$ & 47.9 & 41.3 \\
Max. height of crop trees $(\mathrm{m})$ & $\mathrm{n} . \mathrm{a}$. & 8.1 \\
Aver. tree crown extension $(\mathrm{m})$ & 9.2 & 7.9 \\
Aver. DBH of trees $(\mathrm{cm})$ & $30.3( \pm 24.4)$ & $38.1( \pm 14.7)$ \\
Aver. DBH of crop trees $(\mathrm{cm})$ & $\mathrm{n} . \mathrm{a}$. & $7.3( \pm 2.3)$ \\
Basal area (m ${ }^{2}$ ha ${ }^{-1}$ ) & 62.8 & 26.3 \\
Canopy openness $(\%)$ & 9.7 & 9.8 \\
\hline \hline
\end{tabular}

Basal area refers to stems $\geq 10 \mathrm{~cm} \mathrm{dbh}$.

lawesi, Indonesia, at lower montane elevation (Table 1). Situated in fairly rugged terrain in the Kulawi valley at the western border of Lore Lindu National Park, the natural forest and agroforest plots were selected on slopes with similar inclination $\left(32-37^{\circ}\right)$ at a distance to each other of about $500 \mathrm{~m}$. Characteristically, in the study region undisturbed natural forest covers the upper slope sections whereas agroforest systems replace the forest further downslope.

The natural forest vegetation in the region is a relatively species-rich lower montane moist forest with a height of 35 to $48 \mathrm{~m}$. Common tree genera on the study plots include Castanopsis (Fagaceae), Chionanthus (Oleaceae), Dysoxylum (Meliaceae), Ficus (Moraceae) and Lithocarpus (Fagaceae) (Gradstein et al., in press). The natural forest is an old-growth natural forest with only minor indication of human impact. Canopy cover is about $90 \%$ without major gaps. Timber has been extracted only exceptionally, but the plots were chosen in patches where no signs of cutting were found. However, extraction of rattan (Calamus spp.) was widespread in all types of forest in the region including the natural forest. The agroforest is a plantation of cacao (Theobroma cacao) and coffee (Coffea spp.) established in the understorey of a sparse cover of remaining rainforest trees which cast shade on the plantation. In contrast to the natural forest, a scattered layer of mainly invasive herbs and grasses covers the soil surface.

Natural forest and agroforest stand differed significantly with respect to basal area (Table 1 ). Tree height (stems $\geq 10 \mathrm{~cm} \mathrm{dbh}$ ) in the natural forest was on average $21.9 \mathrm{~m}$, ranging from 6.9 to $47.9 \mathrm{~m}$. The agroforestry plot consisted of 2 to $8 \mathrm{~m}$ high crop trees (about $80 \%$ cacao, $20 \%$ cof- 


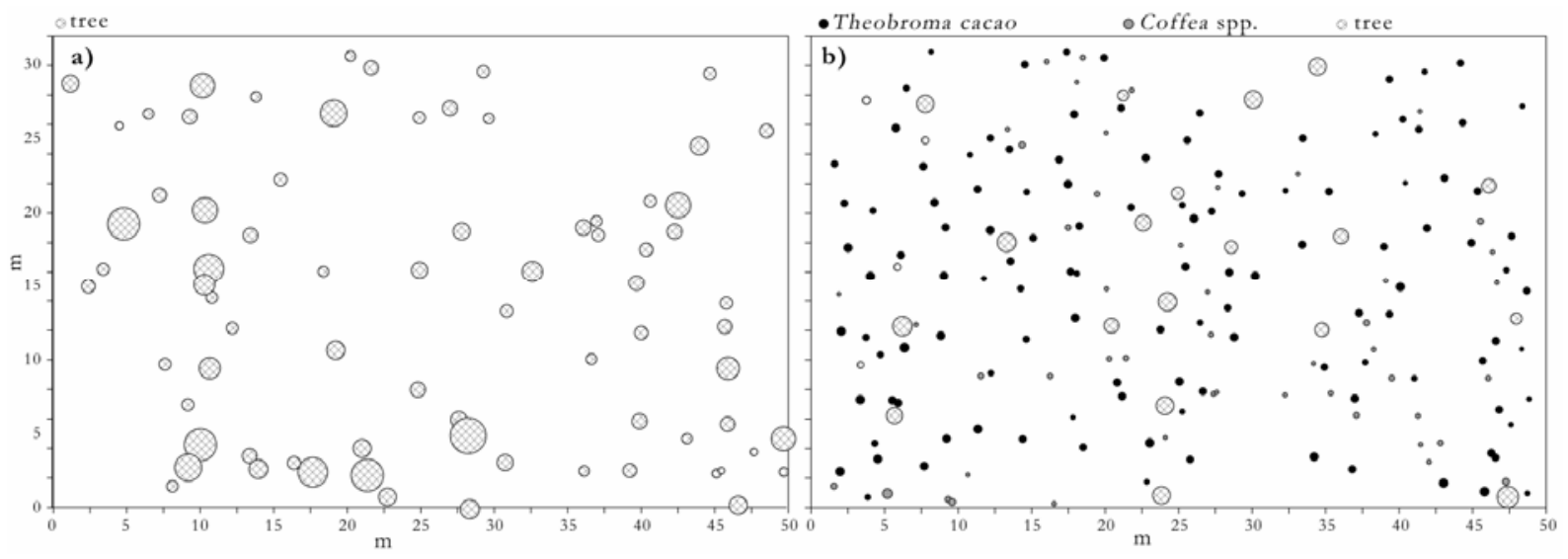

Fig. 1 Map of trees $>10 \mathrm{~cm}$ dbh and of planted cacao or coffee trees in the agroforest (a) and in natural forest (b) studied.

fee) at a density of c. $1500 \mathrm{ha}^{-1}$, and about 150 remaining forest trees per hectare which formed a second canopy layer above the crop trees with an average tree height of $19.1 \mathrm{~m}$ (range $3.8-41.3 \mathrm{~m}$ ). Overall canopy openness was similar between natural forest and agroforest.

In the natural forest plot, the few large trees of the upper canopy layer showed a clumped spatial distribution whereas the trees of the lower strata were more evenly distributed (Figure 1a). The remaining forest trees in the agroforest plot formed an open canopy with a more or less homogenous distribution in space. The canopy of the planted cacao and coffee trees was closed in most of the stand, although gaps were present in about $20 \%$ of the plot area (Figure $1 \mathrm{~b}$ ).

\section{Climate}

Measurements at the Kulawi weather station (about $5 \mathrm{~km}$ from Toro) between 1916 to 1941 yielded a mean annual precipitation of c. $2200 \mathrm{~mm}$ with no clear seasonality. On average, all months have received more than $150 \mathrm{~mm}$ of rain (Berlage 1949). Records at Toro village from 2002 to 2005 showed that, in late summer (August to September), relatively dry months with less than $30 \mathrm{~mm}$ of rain may occur occasionally (H. Kreilein, unpublished data). Rainfall mainly occurs in the late afternoon lasting for 3 to 4 hours. On average, rain events $>0.2 \mathrm{~mm}$ have been recorded on $70 \%$ of the days. Air humidity remains mostly between 75 and $90 \%$, and annual mean air temperature is $23.5^{\circ} \mathrm{C}$.

\section{Throughfall measurements}

On each plot of $32 \mathrm{~m}$ by $50 \mathrm{~m}$ size, a rectangular $3 \mathrm{~m}$ by $3 \mathrm{~m}$ grid with 176 grid points was established and demarcated with red numbered tags. This grid was used to randomly position thirty rain gauges on each plot using a roving gauge modus. Daily measurements were taken each morning within a time span of approximately three hours on both plots to ensure temporal comparability. Gross precipitation was measured close to each plot using either a preinstalled bamboo tower as a platform, or rain gauges installed on long bamboo poles to position the collectors above canopy height. The used rain gauges were manufactured from plastic funnels with a diameter of $194 \mathrm{~mm}$. They were attached to a flexible plastic tube leading into a canister for collecting the trapped water. The funnel, tube and canister were attached to a metal pole with the opening placed at $100 \mathrm{~cm}$ height. A small meshed net was inserted into the tube to prevent litter from contaminating the collected rainwater and ping pong balls tapped the funnel, minimizing possible evaporation losses during hot daytime hours. The same method was employed for the gross precipitation collectors, using the same funnels and tubes attached to bamboo. After each measurement, the funnels and meshes were cleaned to ensure a free drainage of the collected water into the canister.

Throughfall amount was converted from measured volume $(\mathrm{ml})$ to water height per area $(\mathrm{mm})$ using the known aperture of the funnel and finally 
expressed as percent throughfall of gross precipitation (hereafter termed relative throughfall height, rTF).

\section{Estimation of leaf area index}

Hemispherical photographs of the canopy from below were used to calculate the one-sided leaf area index (LAI, in $\mathrm{m}^{2} \mathrm{~m}^{-2}$ ) of the two stands using the WinSCANOPY Pro 2004a programme (Régent Instruments, Quebec, Canada) which bases on the inverted Lambert-Beer law (Campbell 1986, Welles and Norman 1991). A photograph was taken vertically upward (Nikon Coolpix 995 with Fisheye Converter FC-E8 0.21x) at each of the 176 grid points per plot used for throughfall measurements. The camera and lens were mounted on a tripod equipped with a cardanic suspension. A built-in compass allowed for the north-south orientation of the lens. All hemispherical photographs were taken at $100 \mathrm{~cm}$ above ground surface. They were analyzed with the WinSCANOPY programme.

The skygrid was set at $30^{\circ}$ to restrict the analysis to a smaller area in accordance to the rather tight $3 \mathrm{~m}$ by $3 \mathrm{~m}$ grid as well as the strong sloping of the plots. Gap fraction and mean leaf angle were then calculated. The gap fraction in the WinSCANOPY programme is defined as the amount of unobstructed sky expressed as a fraction with 1 being $100 \%$ open sky and 0 being no open sky. It is calculated by the number of sky pixels divided by the total number of pixels in the analyzed area.

Leaf area index was estimated using two different methods, the LAI-2000 G ('generalized') mode in which the field of view and the number of elevation rings is modified in comparison to the original LAI-2000 calculation method, and the LAI-2000 E ('ellipsoid model') which assumes an ellipsoidal distribution of leaf area and a non-linear elimination curve fitting to relate LAI to gap fraction. The ellipsoidal model also allows the calculation of mean leaf angles and leaf angle distribution (Campbell 1986, Welles and Norman 1991, WinSCANOPY Pro 2004a Manual).

\section{Statistical analyses}

Prior to analysis, the distribution of all data sets was analysed for normality using the Shapiro \& Wilk test. For two non-normally dis- tributed sample-data sets, a Wilcoxon $\mathrm{U}$ test after Mann \& Whitney was performed, for a larger number of samples a Kruskal-Wallis test. All analyses were done with SAS, version 8.1 (SAS Institute Inc., Cary, NC, USA). Significance was always tested at $p<0.05$. To detect dependencies between throughfall height and stand structural parameters, a Spearman Rank Correlation test was conducted. Linear or exponential regressions were calculated with the programme Xact 7_2 (SciLab, Hamburg, Germany).

\section{Results}

Spatial variability of throughfall

Between 10 June and 30 July 2004, 26 days with rainfall were studied in detail in the natural forest and the agroforest stand. Gross precipitation varied between 0.4 and $54.4 \mathrm{~mm}$ for these rainy days. On average, $39.0( \pm 27)$ and $75.7( \pm 45.1) \%$ of gross precipitation were recorded as throughfall in the natural forest and agroforest stand, respectively. This difference was significant at $p<0.001$.

Relative throughfall height (rTF) increased from 32 to $58 \%$ with increasing gross precipitation height (0-2 to $10-5 \mathrm{~mm}$ ) in the natural forest, and from 63 to $97 \%$ in the agroforest stand (Table 2). Heavy rainfalls $>15 \mathrm{~mm}$ apparently led to a decrease in rTF in both vegetation types.

The spatial variation of throughfall in the stand as expressed by the coefficient of variation (cv) over all 30 collectors differed with gross precipitation height. Rainy days with less than $2 \mathrm{~mm}$ resulted in a very high spatial variability of throughfall in the natural forest $(c v=105 \%)$,

Table 2 Mean and range of relative throughfall height (in percent of gross precipitation) in the natural forest and the agroforest system for four different precipitation classes.

\begin{tabular}{lrrrrr}
\hline & \multicolumn{3}{c}{ Natural forest } & & \multicolumn{2}{c}{ Agroforest } \\
\cline { 2 - 3 } \cline { 5 - 6 } & mean $\pm s d$ & range & & mean $\pm s d$ & \multicolumn{1}{c}{ range } \\
\hline$>0 \mathrm{~mm}$ & $39 \pm 27$ & $0-212$ & & $76 \pm 45$ & $0-365$ \\
$0-2 \mathrm{~mm}$ & $32 \pm 34$ & $0-212$ & & $63 \pm 36$ & $0-206$ \\
$2-5 \mathrm{~mm}$ & $35 \pm 23$ & $6-134$ & & $62 \pm 29$ & $15-176$ \\
$5-10 \mathrm{~mm}$ & $43 \pm 21$ & $13-113$ & & $75 \pm 35$ & $12-174$ \\
$10-15 \mathrm{~mm}$ & $58 \pm 23$ & $6-122$ & & $97 \pm 51$ & $13-268$ \\
$>15 \mathrm{~mm}$ & $43 \pm 18$ & $0-$ & 93 & $89 \pm 59$ & $15-265$ \\
\hline \hline
\end{tabular}


Table 3 Mean coefficients of variation (in percent of the mean) for spatial heterogeneity of relative throughfall in the natural forest and agroforest system as dependent on gross precipitation height.

\begin{tabular}{|c|c|c|c|c|c|}
\hline \multirow{2}{*}{\multicolumn{2}{|c|}{$\begin{array}{l}\text { Gross Precipitation } \\
\mathrm{mm}\end{array}$}} & \multicolumn{2}{|c|}{ Natural forest } & \multicolumn{2}{|c|}{ Agroforest } \\
\hline & & $c v \%$ & $n$ & $c v \%$ & $n$ \\
\hline & $>0$ & 42 & 988 & 46 & 985 \\
\hline 0 & -2 & 105 & 209 & 58 & 209 \\
\hline 2 & -5 & 57 & 419 & 64 & 448 \\
\hline & -10 & 50 & 90 & 47 & 60 \\
\hline & -15 & 40 & 90 & 52 & 149 \\
\hline & $>15$ & 42 & 180 & 66 & 119 \\
\hline
\end{tabular}

which was much lower in the agroforest stand $(c v=58 \%$, Table 3). With increasing gross precipitation, spatial variation of rTF rapidly decreased in the natural forest to a $\mathrm{CV}$ of less than $50 \%$ for days $>10 \mathrm{~mm}$. In contrast, the dependence of spatial throughfall variability on rainfall height was less clear in the agroforest where CV values seemed to increase again for rainfall days $>10 \mathrm{~mm}$ (Table 3 and Fig. 2).
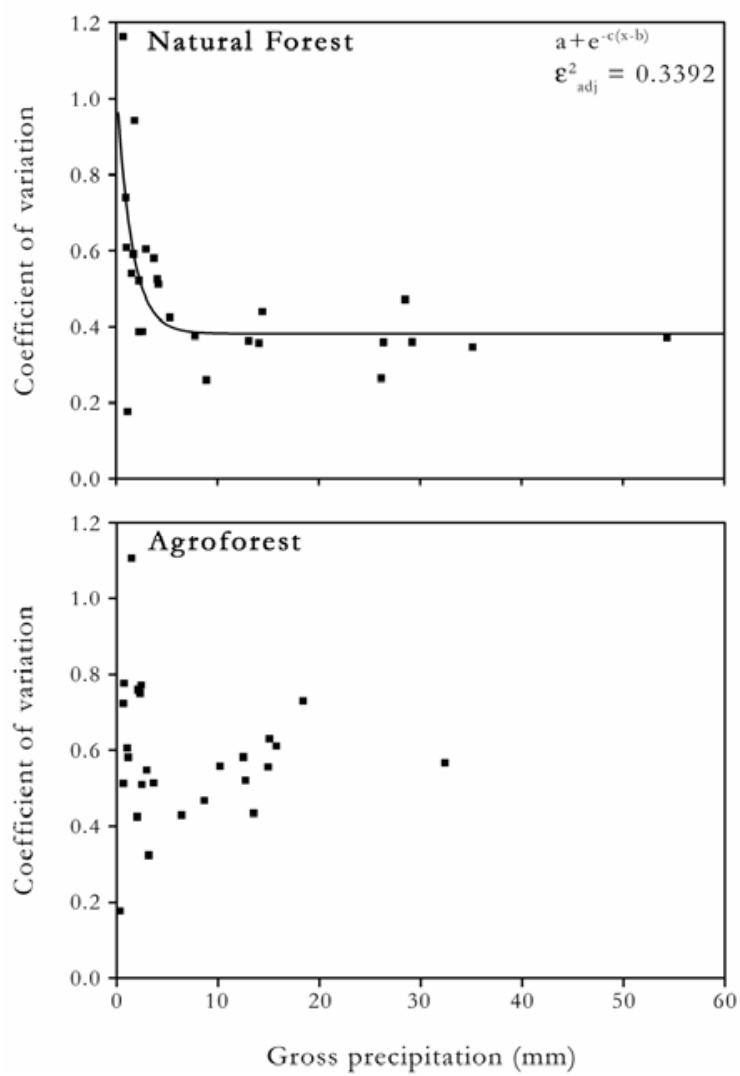

Fig. 2 Relationship between the coefficient of spatial variation $(c v)$ in relative throughfall height $(\mathrm{rTF})$ on gross precipitation height in the natural forest and the agroforest stand.
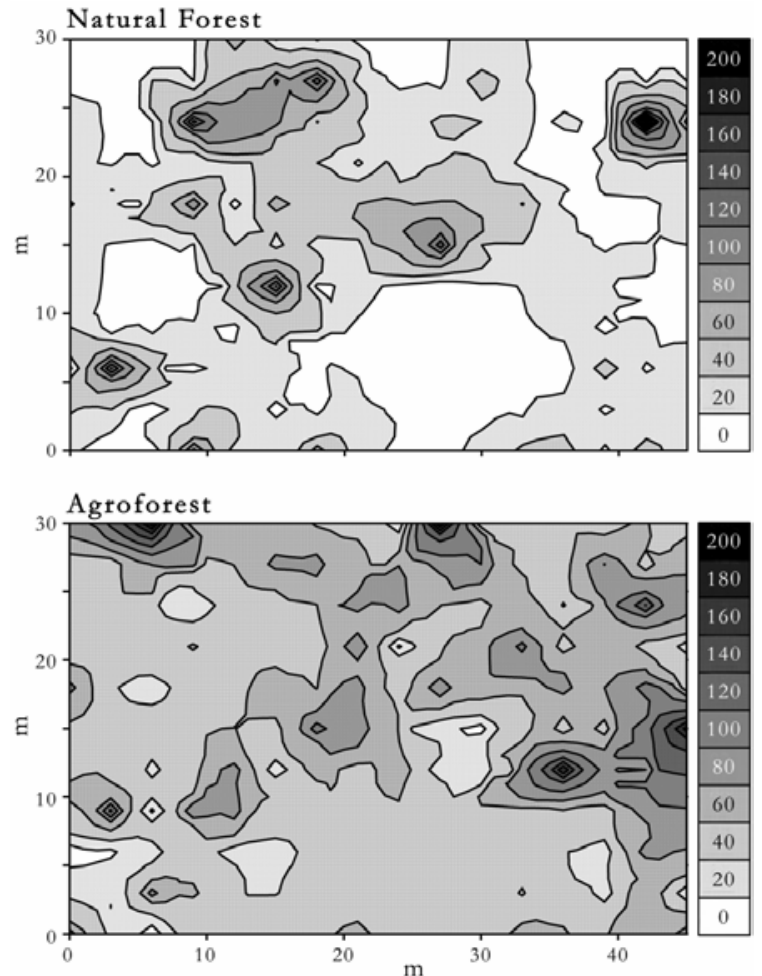

Fig. 3 Spatial distribution of relative throughfall height in the agroforest and natural forest stand for days with gross precipitation of $0-2 \mathrm{~mm}$ (units are $\%$ of gross precipitation).

The contour maps of relative throughfall height in figures 3 and 4 also indicate these opposing trends in spatial variability of rTF with rainfall height in the two vegetation types. At very low rainfall height $(<2 \mathrm{~mm})$, a much larger spatial variation of rTF existed in the natural forest compared to the agroforest stand (Fig. 3). A contrasting picture emerges under high gross precipitation $(>15 \mathrm{~mm})$ with a reduced spatial variability of relative throughfall height in the natural forest but a relatively heterogeneous pattern in the agroforest stand (Fig. 4).

Measurements of rTF conducted at a given plot coordinate during subsequent rainy days gave an indication of temporal variability of throughfall height in the stand (Fig. 5). Since relative throughfall height reached higher maxima in the agroforest, temporal variability of rTF was higher in this stand than in the natural forest.

The throughfall - LAI relationship

Canopy gap fraction ranged between 3.7 and $16.4 \%$ at the 176 plot coordinates of the natural forest and between 1.4 and $36.2 \%$ in the agroforest stand. While the averages $(9.9 \pm 2.7 \%$ 

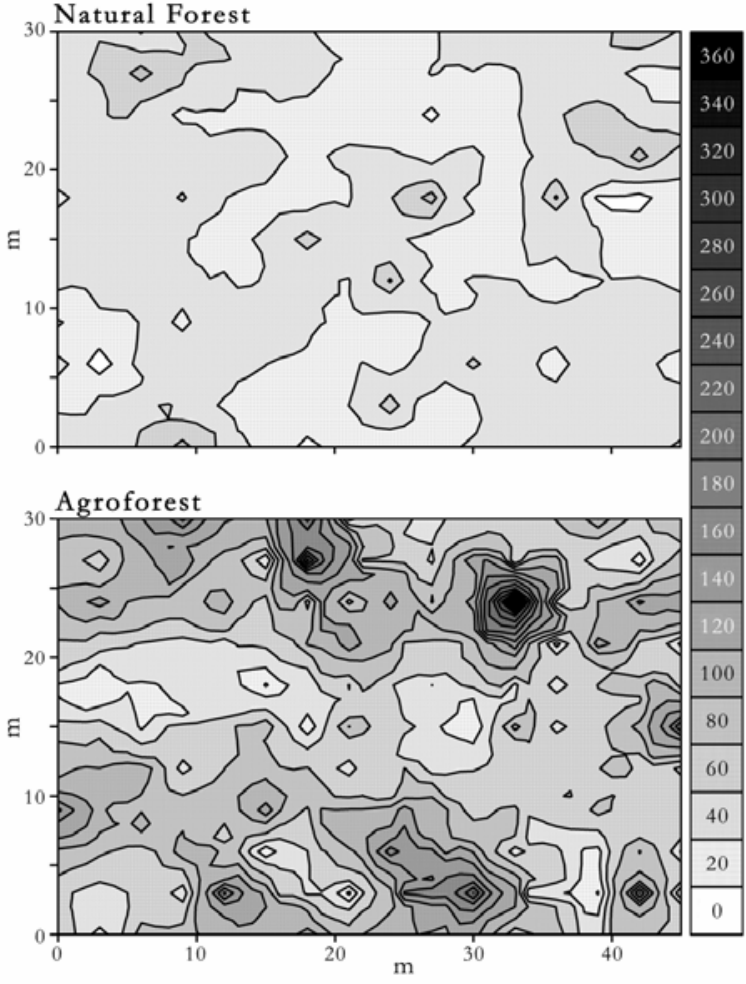

Fig. 4 Spatial distribution of relative throughfall height in the agroforest and natural forest stand for days with gross precipitation of $>15 \mathrm{~mm}$ (units are $\%$ of gross precipitation).

in the natural forest, $10.8 \pm 6.4 \%$ in the agroforest stand) were similar, the range and coefficient of variation of gap fraction was larger in the agroforest than in the natural forest, indicating a spatially more heterogeneous canopy structure in the former.
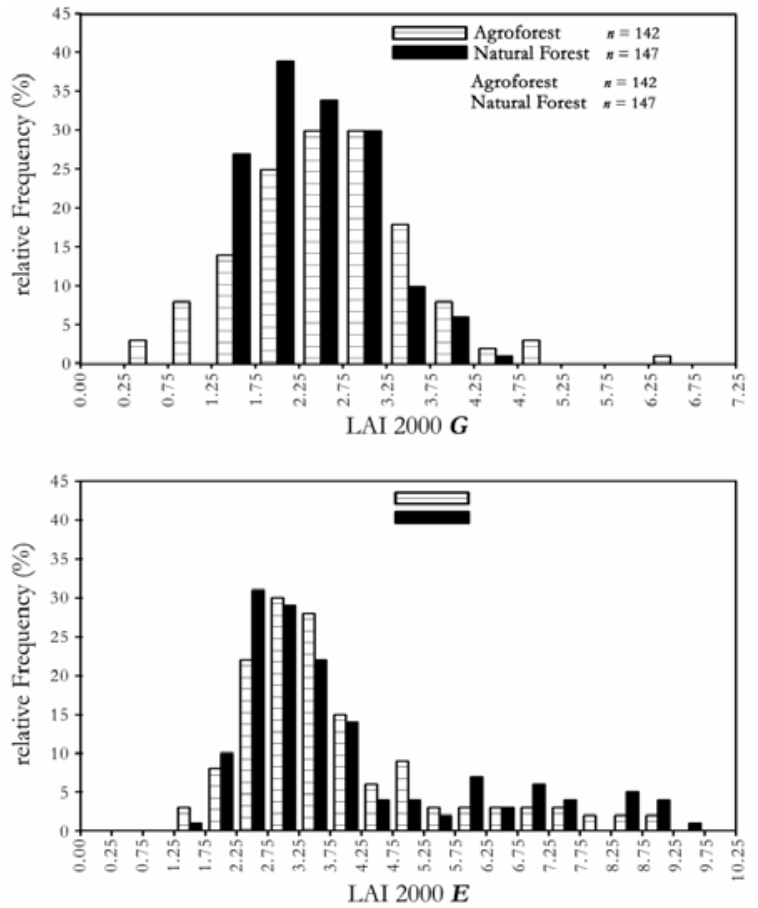

Fig. 6 Frequency histograms for leaf area index at each 142 or 147 plot locations in the natural forest and agroforest stand as estimated by hemispherical photography and the LAI-2000 generalized calculation method (above) or the LAI-2000 ellipsoid calculation method (below).

Leaf area index as estimated with two different calculation methods based on optical measurement yielded average values for the natural forest of $2.85( \pm 0.95$, LAI- $2000 \mathrm{G})$ and $4.07( \pm 1.59$, LAI-2000 E), and for the agroforest stand of 2.68 $( \pm 0.68)$ and 4.24 ( \pm 1.93). The LAI - 2000 E me-
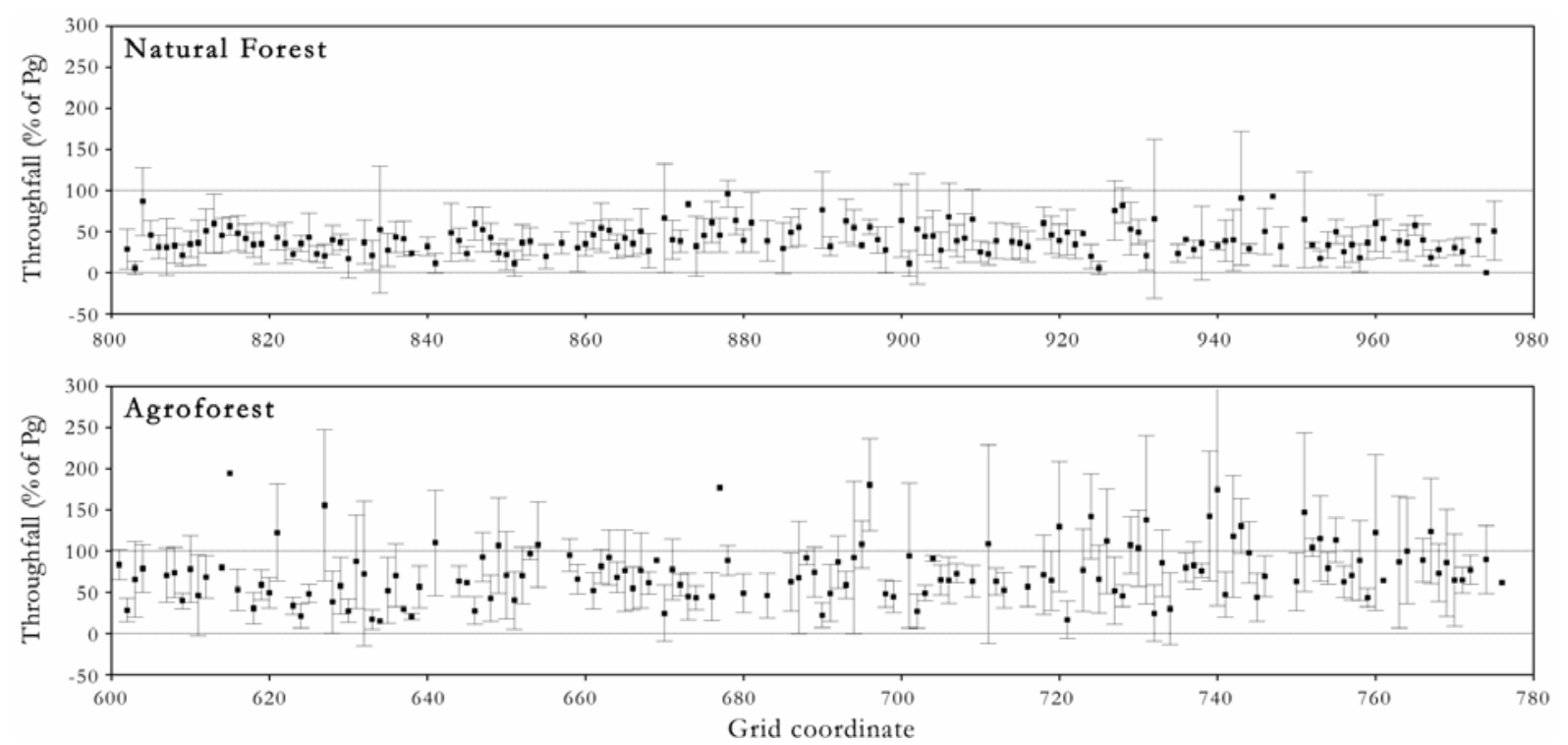

Fig. 5 Mean throughfall height relative to gross precipitation $(\mathrm{Pg})$ and its variability during 26 rainfall days at each 176 plot locations in the natural forest and agroforest stand (mean \pm SD). 
thod gave always significantly higher values (Figure 6). Differences between the two vegetation types were neither significant with the LAI-2000 G nor with the LAI-2000 E approach. In the sample of 176 plot coordinates, LAI showed a typical non-parametric, leptokurtic distribution in both the natural forest and the agroforest stand with the LAI-2000 E calculation method. The LAI-2000 G approach yielded a frequency distribution that was closer to a Gaussian one.

Mean leaf angles as derived from the LAI$2000 \mathrm{E}$ measurement ranged widely between 14.7 and $82.4^{\circ}$ in the two vegetation types, with means of $31.5^{\circ}( \pm 24.4)$ and $29.2^{\circ}( \pm 23.7)$ in natural forest and agroforest, respectively. The two means were not significantly different from each other.

Relative throughfall height was tested for dependence against the canopy parameters gap fraction, leaf area index as estimated by LAI-2000 G or LAI-2000 E, and mean leaf angle using the Spearman rank correlation test (Table 4). Relative throughfall increased significantly with gap fraction in the agroforest stand (for all rainfall days and for the 0-5 and 10-15 mm classes), but did not so in the natural forest. LAI (as estimated with the LAI-2000 G approach) had a significant negative effect on $\mathrm{rTF}$ in both natural forest and agroforest (except for high-rainfall days in the latter). In con- trast, no such relation appeared when LAI was calculated with the LAI-2000 E procedure. Finally, rTF increased significantly with mean leaf angle as long as rainfall height was below $5 \mathrm{~mm}$ (agroforest) or $10 \mathrm{~mm}$ (natural forest).

\section{Discussion}

For analyzing the spatial heterogeneity of water fluxes in complex canopies such as tropical rain forests, the choice of the sampling design is important. We used a high number of collectors, i.e. 30 in a $32 \mathrm{~m}$ by $50 \mathrm{~m}$ plot, which constitutes a cumulative collector aperture area of $>0.5 \%$ of the stand area. Compared to other throughfall studies, this is a relatively large collector area. In multi-layered, complex forest canopies, drip points play a crucial role for the water transfer from the leaves to the ground. Therefore, the collectors were placed according to the roving gauge approach with the gauges being moved in regular intervals to ensure a reliable sampling of the whole plot. The roving method has proved to be a suitable tool in sampling throughfall because it increases the chance of including drip points in the sampling (Lloyd and Marques 1988, Holwerda et al. 2006).

Table 4 Results of a Spearman Rank Correlation test for the dependence of relative throughfall height on canopy gap fraction and leaf area index as estimated by two different methods (LAI $2000 \mathrm{G}$ and LAI $2000 \mathrm{E}$ ) for different gross precipitation classes.

\begin{tabular}{|c|c|c|c|c|c|c|c|}
\hline \multirow{2}{*}{$\begin{array}{l}\text { Net Precipitation } \\
\mathrm{mm}\end{array}$} & \multirow[t]{2}{*}{ Measurement } & \multicolumn{3}{|c|}{ Natural forest } & \multicolumn{3}{|c|}{ Agroforest } \\
\hline & & $r$ & $p$ & $n$ & $r$ & $p$ & $n$ \\
\hline \multirow[t]{3}{*}{$>0$} & Gap fraction & 0.08 & 0.008 & 988 & 0.3 & $<0.001$ & 985 \\
\hline & LAI $2000 \mathrm{G}$ & -0.21 & $<0.001$ & 988 & -0.32 & $<0.001$ & 985 \\
\hline & LAI 2000 E & 0.01 & 0.763 & 988 & -0.07 & 0.430 & 985 \\
\hline \multirow[t]{3}{*}{$0-2$} & Gap fraction & 0.11 & 0.112 & 209 & 0.21 & 0.003 & 209 \\
\hline & LAI $2000 \mathrm{G}$ & -0.21 & 0.003 & 209 & -0.23 & 0.001 & 209 \\
\hline & LAI $2000 \mathrm{E}$ & 0.13 & 0.054 & 209 & 0.04 & 0.599 & 209 \\
\hline \multirow[t]{3}{*}{$2-5$} & Gap fraction & 0.08 & 0.128 & 419 & 0.26 & $<0.001$ & 448 \\
\hline & LAI $2000 \mathrm{G}$ & -0.27 & $<0.001$ & 419 & -0.25 & $<0.001$ & 448 \\
\hline & LAI $2000 \mathrm{E}$ & 0.04 & 0.466 & 419 & 0.04 & 0.460 & 448 \\
\hline \multirow[t]{3}{*}{$5-10$} & Gap fraction & 0.13 & 0.229 & 90 & 0.14 & 0.287 & 60 \\
\hline & LAI $2000 \mathrm{G}$ & -0.35 & $<0.001$ & 90 & -0.2 & 0.135 & 60 \\
\hline & LAI 2000 E & -0.33 & 0.755 & 90 & -0.04 & 0.769 & 60 \\
\hline \multirow[t]{3}{*}{$10-15$} & Gap fraction & 0.13 & 0.209 & 90 & 0.22 & 0.007 & 149 \\
\hline & LAI $2000 \mathrm{G}$ & -0.24 & 0.026 & 90 & -0.19 & 0.018 & 149 \\
\hline & LAI $2000 \mathrm{E}$ & 0.02 & 0.822 & 90 & -0.12 & 0.158 & 149 \\
\hline \multirow[t]{3}{*}{$>15$} & Gap fraction & 0.19 & 0.010 & 180 & 0.15 & 0.109 & 119 \\
\hline & LAI $2000 \mathrm{G}$ & -0.20 & 0.007 & 180 & -0.14 & 0.145 & 119 \\
\hline & LAI 2000 E & -0.10 & 0.197 & 180 & 0.01 & 0.936 & 119 \\
\hline
\end{tabular}

Significant relations $(p<0.05)$ are printed in bold. 
With $39( \pm 27) \%$, the stand average of relative throughfall height for 26 intensively studied rainfall days was low compared to other hydrological studies in undisturbed tropical lowland forests. For lowland or lower montane forests of South-East Asia (Kalimantan, Brunei, Malaysia), rTF values between 77 and $90 \%$ have been reported (Abas et al. 1992, Dykes 1997, Asdak et al. 1998, Burghouts et al. 1998, Chappell et al. 2001, Manfroi et al. 2004). Even though studies in African and South American rainforests include somewhat lower rTF values in the range of 60 to $70 \%$, our value for the Toro natural forest remains at the lower end of global rTF values from tropical moist forests. An extremely small rTF value, however, was also reported by Hölscher et al. (1998) in a monospecific secondary forest of the eastern Amazon (38\% of gross precipitation) which was explained by the authors by the unique canopy structure of the respective species in this stand supporting a very high stemflow.

A possible explanation of the low rTF values in Sulawesi could be our gross precipitation measurement technique which used gauges on a bamboo tower at $7 \mathrm{~m}$ height above the ground in a gap. This contrasts with the widespread practice of measurement close to the ground in forest gaps where precipitation may be reduced under certain circumstances, thus yielding higher rTF values. Another cause could be a larger amount of epiphytes in the Sulawesi natural forest at lower montane elevation which may contrast with lowland forests.

The values of rTF for the agroforest stand $(75.7 \pm 45.1 \%)$ are within the range of values reported in literature for these ecosystem types. However, rTF in agroforest systems appears to be largely dependent on management and crop type. Cardamom agroforests in India allowed $64 \%$ of rTF, whereas pepper and mixed agroforest systems received close to $100 \%$ of rTF (Moench et al. 1991). Homegardens in Java, Indonesia, are reported with $92 \%$ (Jensen 1993) and multistrata agroforests in Central Amazonia, Brazil, with $90 \%$ (Schroth et al. 1999). Most comparable to the present study is the investigation of two cacao agroforest systems with different shade trees in Costa Rica that received 84 and $85 \%$ of rTF (Imbach et al. 1989).

Spatial variation of rTF was very high in both vegetation types in Sulawesi. Throughfall amounts far exceeding gross precipitation occurred at many locations in the natural forest (with a peak value of $212 \%$ of gross precipitation), and especially in the agroforest stand (maximum $365 \%$ ). The likely reason for very high local throughfall fluxes is dripping water from large leaves together with water which is effectively channeled by the branches of certain tree species. Relative throughfall height values $>100 \%$ occurred at low and high rainfall amounts, but they reached higher maxima in the agroforest stand where average leaf size (in particular that of cacao) was greater than in the natural forest probably enhancing drip from leaf tips at ample rain. In both stands, steep gradients of rTF occurred on small spatial scales with throughfall amounts differing by factors of 3 to 5 or more on distances of a few meters.

An interesting discovery of the current study is that the spatial variation of rTF decreased with the amount of gross precipitation in the natural forest, but did not so (or rather increased) in the agroforest. Decreases in spatial variability of rTF with rainfall height have previously been reported from broad-leaved and coniferous forests of the temperate, Mediterranean and sub-tropical zones (Aussenac 1970, Kimmins 1973, Presslan 1973, Loustau et al. 1992, Llorens et al. 1997, CarlyleMoses et al. 2004). The very high rTF variation in the natural forest at low rainfall height $(0-2 \mathrm{~mm})$ can be explained by the fact that such rainfall amounts are not sufficient for saturating the water storage capacity of the canopy in the whole stand, thus resulting in canopy patches where leaf drip occurs and others where all water is retained. In the agroforest stand, it appears that a more homogenous lower canopy formed by the large cacao leaves and those of coffee trees allow for a more homogenous throughfall generation at low rainfall intensities. In contrast, at higher storm intensities $(>10 \mathrm{~mm})$, the agroforest stand showed a greater spatial heterogeneity of throughfall than the natural forests. We assume that this is caused by the patchy upper canopy together with the umbrella-shaped crown architecture of the cacao trees where large branches are effectively channeling water to stemflow while the leaves are promoting local canopy drip (pers. observ.).

We conclude that conversion of natural forest to agroforest with sparse cover of shade trees, which is a widespread practice in the remaining 
rainforest areas of South-East Asia, is changing throughfall patterns substantially. Due to the following three processes this may promote soil erosion even in agroforest stands with closed crop canopy. First, average throughfall amount is comparably high in these systems because interception is reduced when establishing agroforestry systems and extracting many timbers (Dietz et al. 2007). Second, spatial heterogeneity of throughfall is greater in agroforestry stands, in particular under high rainfall amounts resulting in patches with very high, or low, water amounts reaching the soil surface. In fact, throughfall amounts exceeding gross precipitation by more than $300 \%$ only occurred in certain locations of the agroforest stand but not in the natural forest. This partly supports our hypothesis on spatial rTF variability, but a high variability is restricted to larger rainfall amounts $(>10 \mathrm{~mm})$. Extreme throughfall events of this intensity have a high probability of causing severe soil erosion in sloped terrain. Finally, canopy closure by recently planted cacao trees may take two or three years in the study area. During this time, an even higher risk of erosion may exist.

Leaf area index and canopy gap fraction, but also leaf angles, are canopy attributes that were assumed to influence rTF to a certain extent. Holwerda et al. (2006) estimated LAI on 160 sampling positions in a lower montane forest of Puerto Rico by above and below canopy PAR measurements and the application of a light extinction coefficient. When relating these values to measured rTF they also found a relationship between canopy structure and hydrology that was only weakly significant. At low rainfall amounts $(0-2.5 \mathrm{~mm})$ the negative relation between $\mathrm{rTF}$ and LAI was tighter $\left(r^{2}=0.21\right)$ than at rainfalls $>10 \mathrm{~mm}\left(r^{2}=0.06\right)$. In a lowland rain forest of Costa Rica at La Selva, Löscher et al. (2002) measured canopy characteristics by spherical densiometers above 56 throughfall collectors. An increasing canopy openness was weakly correlated with an increasing relative throughfall amount $\left(r^{2}=0.1, p<0.02\right)$.

In the present study, none of the canopy structure parameters yielded high coefficients of determination and, thus, may only function as codeterminants of throughfall height in the studied vegetation types. Apparently, other variables such as tree height and aerodynamic canopy roughness length (Dietz et al. 2007), foliage clumping, epiphyte abundance and species-specific surface properties of leaves and twigs may also be important in determining throughfall height. Furthermore, the obtained results should be assessed with caution because the mentioned methodological problems related to optical canopy analysis in complex forest stands have to be kept in mind. The LAI data as calculated with the LAI$2000 \mathrm{G}$ ('generalized') mode are far from realistic and may primarily be used for comparison among stands. In particular, the two-layered canopy in the agroforest systems seems to constitute a serious problem to optical leaf area determination. These difficulties might have markedly influenced the results on LAI and, thus, may have masked any relationships between canopy attributes and throughfall height.

Acknowledgements This study was conducted in the framework of the STORMA research project (Stability of Rain Forest Margins in Indonesia, SFB 552, subproject B4). The financial support granted by the German Research Foundation (DFG) is gratefully acknowledged.

\section{References}

Abas MR Ahmadshah A, Awang MN (1992) Fluxes of ions in precipitation, throughfall and stemflow in an urban forest in Kuala-Lumpur, Malaysia. Environ Poll 75:209-213

Achard F, Eva HD, Stibig HJ, Mayaoux P, Gallego J, Richards T, Malingreau JP (2002) Determination of deforestation rates of the world's humid tropical forests. Science 297:999-1002

Asdak C, Jarvis PG, van Gardingen P, Fraser A (1998) Rainfall interception loss in unlogged and logged forest areas of Central Kalimantan, Indonesia. J Hydrol 206:237-244

Aussenac G (1970) Action du couvert forestier sur la distribution au sol des précipitation. Ann For Sci 27:383-399

Berlage HP (1949) Regenval in Indonesië (Rainfall in Indonesia): gemiddelden v. De regenval voo 4339 waarnemingsplaatsen in Indonesië, berekend uit waarnemingen verricht in het tijdvak 1879-1941

Burghouts TBA, Van Straalen NM, Bruijnzeel LA (1998) Spatial heterogeneity of element and litter turnover in a Bornean rain forest. J Trop Ecol 14:477-505

Carlyle-Moses DE, Laureano JSF, Price AG (2004) Throughfall and throughfall spatial variability in Madrean oak forest communities of northeastern Mexico. J Hydrol 297:124-135

Campbell GS (1986) Extinction coefficients for radiation in plant canopies calculated using an ellipsoidal inclination angle distribution. Agric For Meteor 36:317-321

Chappell NA, Bidin K, Tych W (2001) Modelling rainfall and canopy controls on net-precipitation beneath selectivelylogged tropical forest. Plant Ecol 153:215-229 
Dietz J, Hölscher D, Leuschner Ch, Malik A, Amir MA (2007) Forest structure as influenced by different types of community forestry in a lower montane rainforest of Central Sulawesi, Indonesia. In: Tscharntke T, Leuschner Ch, Zeller M, Guhardja E, Bidin A (eds) The Stability of Tropical Rainforest Margins, linking Ecological, Economic and Social Constraints of Land Use and Conservation. Springer Verlag Berlin, 131-146.

Dykes AP (1997) Rainfall interception from a lowland tropical rainforest in Brunei. J Hydrol 200:260-279

Gradstein SR, Kessler M, Pitopang R (2007) Tree sepcies diversity relative to human land uses in tropical rain forest margins in Central Sulawesi. In: Tscharntke T, Leuschner Ch, Zeller M, Guhardja E, Bidin A (eds) The Stability of Tropical Rainforest Margins linking Ecological, Economic and Social Constraints of Land Use and Conservation. Springer Verlag Berlin, 321-334.

Helmi I (2005) Local people are well-placed to develop zonation plans in Indonesia's Lore Lindu National Park. Tropical Forest Update 15:31-32

Holwerda F, Scatena FN, Bruijnzeel LA (2006) Throughfall in a Puerto Rican lower montane rain forest: a comparison of sampling strategies. J Hydrol (in press)

Hölscher D, Sa TDD, Moller RF, Denich M, Folster H (1998) Rainfall partitioning and related hydrochemical fluxes in a diverse and in a monospecific (Phenakospermum guyannense) secondary vegetation stand in eastern Amazonia. Oecologia 114:251-257

Imbach AC, Fassbender HW, Bore R, Beer J, Bornemann A (1989) Modelling agroforestry systems of cacao (Theobroma cacao) with laurel (Cordia alliodora) and cacao with poro (Erythrina poeppigiana) in Costa Rica - IV. Water balances, nutrient inputs and leaching. Agroforest Syst 8:267-287

Jensen M (1993) Productivity and nutrient cycling of a Javanese homegarden. Agroforest Syst 24:187-201
Kimmins JP (1973) Some statistical aspects of sampling throughfall precipitation in nutrient cycling studies in British Columbian coastal forests. Ecol 54:1008-1019

Llorens P, Poch R, Latron J, Gallart F (1997) Rainfall interception by a Pinus sylvestris forest patch overgrown in a Mediterranean mountainous abandoned area. 1. Monitoring design and results down to the event scale. J Hydrol 199:331-345

Lloyd CR, Marques AD (1988) Spatial variability of throughfall and stemflow measurements in an Amazonian rainforest. Agric For Meteor 42:63-73

Loescher HW, Powers JS, Oberbauer S (2002) Spatial variation of throughfall volume in an old-growth tropical wet forest, Costa Rica. J Trop Ecol 18: 397-407

Loustau D, Berbigier P, Granier A, Moussa FE (1992) Interception loss, throughfall and stemflow in a maritime pine stand.1. Variability of throughfall and stemflow beneath the pine canopy. J Hydrol 138:449-467

Manfroi OJ, Koichiro K, Nobuaki T, Masakazu S, Nakagawa M, Nakashizuka T, Chong L (2004) The stemflow of trees in a Bornean lowland tropical forest. Hydrol Process 18:2455-2474

Moench M (1991) Soil erosion under a successional agroforestry sequence: a case study from Idukki District, Kerala, India. Agroforest Syst 15:31-50

Presslan AJ (1973) Rainfall Partitioning by an Arid Woodland (Acacia aneura F-Muell) in South-Western Queensland. Austral J Bot 21:235-245

Schroth G, Ferreira da Silva L, Wolf M-A, Teixeira WG, Zech W (1999) Distribution of throughfall and stemflow in multi-strata agroforestry, perennial monoculture, fallow and primary forests in central Amazonia, Brazil. Hydrol Process 13:1423-1436

Welles JM, Norman, JM (1991) Instrument for indirect measurement of canopy architecture. Agron J 83:818-825 


\section{Acknowledgements}

This presented work would have been unthinkable without...

Dirk Hölscher. I thank him for his continuous and relentless efforts in guiding and advising me throughout the entire period of my research. His professional experience and his patient, positive and encouraging attitude and our inspiring discussions were vital for the success of this endeavor.

Christoph Leuschner, whose great academic input and administrative support has been invaluable for the productive work environment I enjoyed at the Department of Plant Ecology and beyond.

Luitgard Schwendenmann whose fruitful discussions and suggestions as well as her unweary ear in critical situations were always a stimulating basis, both during data evaluation and the writing processes. My gratitude extends to all my colleagues at the Institute of Tropical Silviculture who have always kept the working days at the institute lively and exciting. This holds especially true for Andreas Parth who not only entertained me for many months with his evident cheerfulness and musical talent but who also salvaged me from occasional computer conflicts.

Heiner Kreilein and his B1 dream team, who were always ready to come up with viable tricks on site in Bariri and were always ready to lend their helping hands at any given time or place.

Heinz Coners as the wire wizard and as a constant competent backup on technical issues. I owe to him the successful operation of the entire sensor setup.

Eva Siegelkow and Astrid Rodriguez as the wonderful office fairies who provided me with essential knowledge on and assistance in a myriad of administrative challenges.

Pak Hendrayanto, Pak Surya Tarigan, Pak Adam Malik, and Pak Amran Amir as our Indonesian counterparts and supporting scientists both in Bogor and Palu who substantially facilitated my field research in Sulawesi.

Wolfram Lorenz, Stefan Köhler, Ibu Rina and Marion Engelhard representing the STORMA staff who were always ready to smoothen edges and assist with unconventional solutions to unconventional problems.

André Twele and all my other colleagues of the STORMA-PhD-students team. I am indebted to them for their very cooperative, understanding and encouraging companionship beyond existing reservations which I enjoyed with them in Sulawesi and in Göttingen.

Pak Berwin Toheke, Pak Rachmat Taro, Pak Fandi, Pak Berto, Pak Arnold, Pak As'at, Pak Husein, and Pak Baswan, on behalf of all my strong and reliable field assistant team. My special thanks also go to the village heads of Toro and Bariri and to Rajab who deserves exceptional gratitude for his responsible housekeeping and delicious cuisine in Toro.

the German Science Foundation (DFG) which funded the project 'Stability of Rainforest Margins in Indonesia' (STORMA) as its SFB 552. This research was conducted within the subproject B4 of the second phase of said project. The financial support is gratefully acknowledged.

Delicia, Steffen and my parents Elfriede and Werner. I thank them for all the moral support and the loving care they always granted to me, no matter whether we were near or far. 


\section{Curriculum Vitae}

Name

Geburtsdatum

Geburtsort

Staatsangehörigkeit

\section{Schulausbildung}

09/1980 - 07/1984

$09 / 1984-07 / 1990$

08/1990 - 05/1991

05/1991

09/1991 - 07/1993

07/1993

\section{Berufsausbildung}

10/1993 - 02/1996

08/1994 - 03/1996

03/1996

\section{Studium}

10/1996 - 11/2002

07/2001 - 10/2001

$11 / 2002$

seit $08 / 2003$

$10 / 2003-05 / 2005$

seit $10 / 2005$

\section{Berufstätigkeit}

08/1994 - 03/1996

03/1996 - 07/1996

$01 / 2003-07 / 2003$

08/2003-08/2006
Johannes Michael Dietz

24. Januar 1974

Würzburg

Deutsch

Grundschule Haslach

Chiemgau Gymnasium Traunstein, Jahrgangsstufen 5 - 10

Pine-Richland Highschool, Gibsonia, PA, U.S.A.

Abschluss: Ordentlicher Highschool-Abschluss „Graduation” mit Diplom

Chiemgau Gymnasium Traunstein, Jahrgangsstufen 12 - 13

Abschluss: Allgemeine Hochschulreife

Staatliche Berufsschule II, Traunstein

Lehre im Bau- und Möbelschreinerhandwerk

Abschluss: Handwerksgeselle im Bau- und Möbelschreinerhandwerk

Universität Bayreuth, Fachrichtung Geoökologie

Diplomarbeit: Variation and Distribution of Forest Types on the Southern Foothills of the Cordillera Cahuapanas, Alto Mayo, Peru.

Feldarbeiten für die Diplomarbeit

(GTZ-DIAM, Ländliche Entwicklung Alto Mayo, Peru)

Abschluss: Diplom-Geoökologe

Hauptfächer: Biogeografie, Bodenkunde

Nebenfächer: Botanik, Umweltgeologie, Geografie der Dritten Welt

Anfertigung der Dissertation zum Thema: Rainfall partitioning in differently used montane rainforests of Central Sulawesi, Indonesia.

Feldarbeiten für die Promotion, Palu, Zentralsulawesi, Indonesien

Promotionsstudium, Fakultät für Forstwissenschaften und Waldökologie, Universität Göttingen

Auszubildender im Bau- und Möbelschreinerhandwerk

Ausbilder im Schreinerhandwerk am Kolping Vocational Training Centre, Kilima Mbogo, Kenia

Consulting für die Deutsche Gesellschaft für Technische Zusammenarbeit (GTZ), Peru: Estudio temporal para calcular la tasa de deforestación en la Cuenca del Alto Mayo, Peru.

Wissenschaftlicher Mitarbeiter, Universität Göttingen

SFB 552, Stability of Rainforest Margins in Indonesia (STORMA) über Änderungen des Wasserkreislaufs entlang eines Gradienten der Waldnutzungsintensität. 